UNIVERSIDADE DE SÃO PAULO

FACULDADE DE ARQUITETURA E URBANISMO

\title{
A GASTRONOMIA PAULISTANA: \\ O LOCAL E O GLOBAL NO MESMO PRATO
}

Isabella Raduan Masano

Orientadora: Prof ${ }^{a}$ Drª Heliana Comin Vargas 



\section{Isabella Raduan Masano}

\section{A GASTRONOMIA PAULISTANA: O LOCAL E O GLOBAL NO MESMO PRATO}

Dissertação apresentada à Faculdade de Arquitetura e Urbanismo da Universidade de São Paulo como requisito para a obtenção do título de Mestre em Arquitetura e Urbanismo.

Área de Concentração: Planejamento Urbano e Regional.

Orientadora: Prof ${ }^{a}$ Drª Heliana Comin Vargas

SÃO PAULO

2011 


\begin{abstract}
AUTORIZO A REPRODUÇÃO E DIVULGAÇÃO TOTAL OU PARCIAL DESTE TRABALHO, POR QUALQUER MEIO CONVENCIONAL OU ELETRÔNICO, PARA FINS DE ESTUDO E PESQUISA, DESDE QUE CITADA A FONTE.
\end{abstract}

E-MAIL: bella@usp.br

Masano, Isabella Raduan

M394g A gastronomia paulistana: o local e o global no mesmo prato / Isabella Raduan Masano. --São Paulo, 2011.

262 p. : il.

Dissertação (Mestrado - Área de Concentração: Planejamento Urbano e Regional) - FAUUSP.

Orientadora: Heliana Comin Vargas

1.Alimentação - Aspectos culturais - São Paulo (SP)

2.Gastronomia - Aspectos socioeconômicos - São Paulo (SP)

I.Título 
Nome: MASANO, Isabella Raduan

Título: A Gastronomia Paulistana:

o local e o global no mesmo prato

Dissertação apresentada à Faculdade de Arquitetura e Urbanismo da Universidade de São Paulo como requisito para a obtenção do título de Mestre em Arquitetura e Urbanismo.

Área de Concentração: Planejamento Urbano e Regional.

Aprovado em:

Banca Examinadora

Prof. Dr.

Instituição:

Julgamento:

Assinatura:

Prof. Dr.

Instituição:

Julgamento:

Assinatura:

Prof. Dr.

Instituição:

Julgamento:

Assinatura: 

Aos meus pais, à Carolina e ao Ivan por darem sabor à minha vida. 



\section{AGRADECIMENTOS}

À Profa. Dra. Heliana Comin Vargas, orientadora desta dissertação, por ter me incentivado a ingressar no mestrado e pelas agradáveis trocas de conhecimento ao longo desses anos.

À Profa. Dra. Heloisa Barbuy e à Profa. Dra. Sueli Schiffer, membros da banca de minha prova de qualificação, pelo interesse demonstrado e pelas valiosas contribuições.

A todos os professores que sempre colaboraram para que eu conseguisse atingir meus objetivos.

Aos jornalistas entrevistados por terem aceitado estar "do outro lado do gravador" e compartilharem comigo suas experiências profissionais e suas visões sobre as gastronomias brasileira e paulistana. Um agradecimento especial ao Ricardo Castanho, por ter me permitido acesso a todas as edições do Guia 4 rodas.

Aos meus colegas e amigos de profissão que, mesmo em meio a toda a correria de final de ano, conseguiram abrir um espaço na agenda para me concederem entrevistas, as quais me permitiram adentrar na intimidade de seus restaurantes, de suas histórias e conhecer ainda mais de perto seus trabalhos.

À minha mãe, pelo apoio incondicional, desde o dia em que nasci. E por ter suprido todas as minhas ausências no Amadeus nos últimos tempos.

Ao meu pai, que acorda pensando no almoço e almoça pensando no jantar, por ter me ajudado a concretizar este trabalho.

À Carolina, por te me ajudado em "todas as frentes". Você é a melhor irmã do mundo! E ao Pomper, cunhado querido, pela paciência e pelo desprendimento.

Ao Ivan, pelo amor, por cada momento compartilhado e pela compreensão em todas as minhas ausências.

Aos meus avós, por terem transmitido a paixão pelos bons momentos ao redor da mesa.

À Estefânia, amiga querida, por ter me estimulado mesmo nos momentos em que eu duvidei deste trabalho, pelas indicações valiosíssimas e traduções.

Ao Rafael Yamamoto, pela ajuda inestimável na finalização e montagem do documento final.

À equipe do restaurante Amadeus, pelas experiências compartilhadas. 
Ao sociólogo Carlos Alberto Dória, pelos textos, pelas aulas na Unicamp, pelos bate-papos e pela veia crítica que desafia nossa ingenuidade juvenil.

À Marina Heck, pelas agradáveis conversas, eventos conjuntos e por todas as vezes em que me abriu as portas de sua casa e compartilhou comigo seus saberes e sabores.

À família Sodré, na qual incluo também Juliana Braga, pelas dicas, pelo carinho e pelo passe livre "no clube". Espero voltar a frequentá-lo em breve!

Aos amigos da ARBL, em especial ao saudoso Paulo Martins, pela sincera amizade e por terem me descortinado tantos encantos desse Brasil.

Aos amigos da FAU, pelas discussões a respeito do tema e pelo apoio nos momentos de aflição.

À Laurita e à Ana Luiza, pelo apoio sempre que precisei.

Aos amigos e colegas do slow food, por compartilharem comigo o sonho de um mundo melhor. Em especial à Claudinha, pelas boas energias, e à Cenia, pelos cardápios.

Ao Lorenzo, pelas discussões sobre globalização e sobre o futuro do planeta.

Ao "Pira", pela companhia ao longo dessa caminhada, pelos livros que me emprestou e pelo auxílio no período de minha qualificação.

Aos amigos da ECA por todas as nossas conversas e por muitos dos momentos mais divertidos da minha vida.

À Maria Helena Amaral Muniz de Carvalho pelas palavras de carinho e pela revisão dos textos.

À Paulinha Gabbai e à Mila Santoro, pelas graciosas ilustrações e pelo projeto gráfico.

Às equipes da Secretaria e da Biblioteca da FAU-Maranhão, que sempre me auxiliaram.

A todos os amigos de prosa e panela, pelas discussões, risadas e garfadas.

E, finalmente, a todos aqueles que, embora não mencionados nominalmente, contribuíram para este trabalho com idéias, sugestões ou demonstrações de amizade. 
"Achamos que conhecemos nossos hábitos culinários porque foram os mesmos durante séculos. No entanto, [...] percebemos que estamos nos aventurando numa terra estranha e desconhecida, onde o que é familiar foi recriado no passado recente."

Rachel Laudan 



\section{RESUMO}

O presente trabalho aborda questões relativas à pluralidade e ao dinamismo da mesa paulistana, explorando a comida para além de sua característica nutricional, em seus aspectos sócio-cultural e econômico. Para tanto, considera as condicionantes que levam a essa diversidade que caracteriza a gastronomia paulistana, como o passado colonial e os intensos fluxos migratórios, destacando também a realidade de uma cidade cosmopolita, global. Discute, igualmente, transformações que vêm ocorrendo na cidade de São Paulo e que impactam o mercado de alimentação; caracterizando-a como o principal polo gastronômico do país e maior mercado brasileiro. Em adição à discussão teórica, expõem-se entendimentos e percepções sobre esse mercado de alimentação em São Paulo, colhidos em entrevistas realizadas com chefs e proprietários de restaurantes e jornalistas especializados na área. Assim, oferece um panorama da mesa paulistana e fomenta uma atitude reflexiva a respeito da gastronomia na cidade de São Paulo.

Palavras-chave: Gastronomia. Restaurantes. Alimentação e cultura. Alimentação e consumo. São Paulo. 



\begin{abstract}
This dissertation deals with issues regarding the plural and dynamic aspects of the cuisine from the city of São Paulo (paulistana cuisine), approaching food from its sociocultural and economic aspects and going beyond its nutritional content. In order to do so, it considers the factors that have created the diversity that characterises paulistana gastronomy, such as its colonial past, the intense migration flows that marked it, as well as its reality as a cosmopolitan, global, city. It also discusses the changes that have been taking place in the city, as Brazil's main gastronomic hub and market, and which have an impact on the food market. In addition to the theoretical investigation, the dissertation presents interviews carried out with chefs, restaurant owners and journalists specialised in gastronomy, showing their opinions and perceptions regarding the food market in São Paulo. Hence, this dissertation portrays São Paulo's food scene and foments a reflective attitude towards gastronomy in the city.
\end{abstract}

Key-words: Gastronomy. Restaurants. Food and culture. Food and consumption. São Paulo. 



\section{LISTA DE SIGLAS}

ABIA: Associação Brasileira das Indústrias da Alimentação

ABIPECS: Associação Brasileira da Indústria Produtora e Exportadora de Carne Suína

ABRAS: Associação Brasileira de Supermercados

ABRASEL: Associação Brasileira de Bares e Restaurantes

APROVALE: Associação dos Produtores de Vinhos Finos do Vale dos Vinhedos

CAGESP: Companhia de Armazéns Gerais do Estado de São Paulo

CEAGESP: Companhia de Entrepostos e Armazéns Gerais de São Paulo

CEASA: Centro Estadual de Abastecimento

EMBRAPA: Empresa Brasileira de Pesquisa Agropecuária

ENDEF: Estudo Nacional da Despesa Familiar

FAO: Organização das Nações Unidas para Agricultura e Alimentação

FGV: Fundação Getúlio Vargas

FUNAI: Fundação Nacional do Índio

IBGE: Instituto Brasileiro de Geografia e Estatística

IHGB: Instituto Histórico e Geográfico Brasileiro

INPI: Instituto Nacional da Propriedade Industrial

IPC: Índice de Potencial de Consumo

MSP: Município de São Paulo

MTE: Ministério do Trabalho e Emprego

ONU: Organização das Nações Unidas

PNAD: Pesquisa Nacional por Amostra de Domicílios

POF: Pesquisa de Orçamentos Familiares

RMSP: Região Metropolitana de São Paulo

SENAC: Serviço Nacional de Aprendizagem Comercial

SPI: Serviço de Proteção ao Índio

UNB: Universidade de Brasília 



\section{LISTA DE TABELAS}

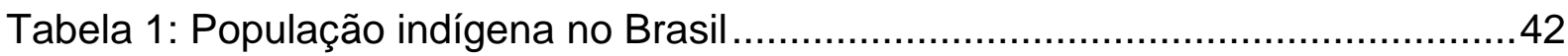

Tabela 2: Estimativa de imigração portuguesa para o Brasil (1500-1991) ................50

Tabela 3: Tráfico negreiro com destino ao Brasil e Américas …………………......59

Tabela 4: Distribuição percentual da população estrangeira por regiões..................67

Tabela 5: Imigração registrada de quatro países (1871-1920)...............................69

Tabela 6: Distribuição dos Estrangeiros em São Paulo: Nacionalidade e

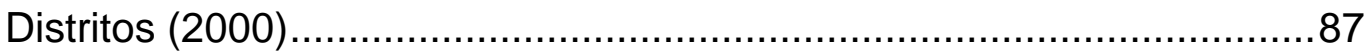

Tabela 7: Distribuição percentual do valor da produção industrial brasileira

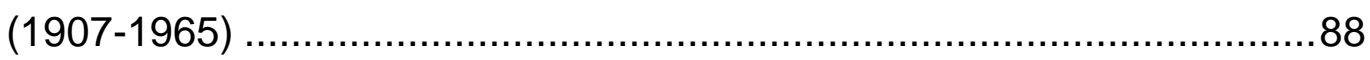

Tabela 8: Migração para a cidade de São Paulo (1900-1960) .................................89

Tabela 9: Correntes migratórias para o Município de São Paulo ................................91

Tabela 10: Indicadores do município de São Paulo ..............................................107

Tabela 11: Rendimento mensal das pessoas ocupadas: Brasil e RMSP .................108

Tabela 12: Distribuição da produção industrial (2009) ……………...................116

Tabela 13: Evolução da População - Brasil e São Paulo (1872 - 2010) …….........127

Tabela 14: Evolução da população economicamente ativa por sexo ......................133

Tabela 15 : Percentual das despesas das famílias por faixa de renda - ...................... Brasil e RMSP (1974/75 e 2008/09) ................................................ 138

Tabela 16: Consumo Alimentar por Capitais Selecionadas ..................................140

Tabela 17: Distribuição do consumo alimentar por faixa de renda - Brasil..............144

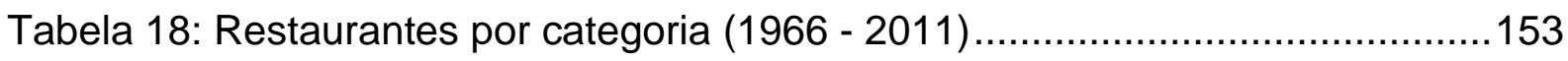

Tabela 19 - Categorias e quantidade de restaurantes com referência em mais

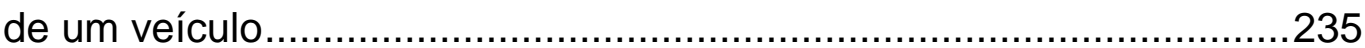

Tabela 20: Evolução na aquisição alimentar domiciliar anual em São Paulo(ENDEF 1974/1975 - POF 2008/2009) …….....................................243

Tabela 21: Aquisição alimentar domiciliar anual - Brasil e Capitais..........................251

Tabela 22: Aquisição Alimentar Domiciliar Anual por Classe de Rendimento.........257 



\section{LISTA DE QUADROS}

Quadro 1 - Espécies exóticas adaptadas no Brasil .................................................53

Quadro 2: As tendências da alimentação....................................................... 148

Quadro 3: Pesquisa exploratória e Pesquisa conclusiva.......................................231

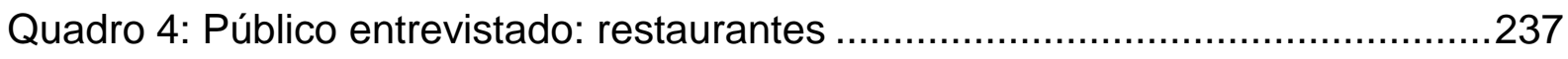

Quadro 5: Público entrevistado: profissionais da mídia especializada ...................238 



\section{LISTA DE GRÁFICOS}

Gráfico 1: Imigração - Brasil e Estado de São Paulo 66

Gráfico 2: Imigração para o Estado de São Paulo por nacionalidade 71

Gráfico 3: Saldos migratórios - RMSP e MSP (1940 - 1991)..................................92

Gráfico 4: Distribuição do IPC e população por classe econômica em São Paulo.. 109

Gráfico 5: Crescimento anual do food service e do varejo (2000 - 2009). 125

Gráfico 6: Dimensionamento do mercado de food service. 126

Gráfico 7: Evolução da participação do emprego feminino em São Paulo..... 133

Gráfico 8: Média de anos de estudo - Brasil (1999/2009) 136

Gráfico 9: Gastos com alimentação dentro e fora do lar (Região Metropolitana de São Paulo) 145 



\section{LISTA DE FIGURAS}

Figura 1: Triângulo culinário de Lévi-Strauss ......................................................

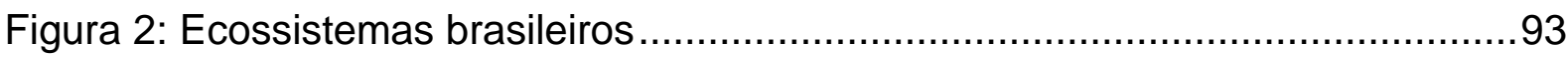

Figura 3: Distribuição do IPC - Alimentação fora do lar por distrito em São Paulo.110

Figura 4: Feiras por distritos e subprefeituras no Município de São Paulo ..............120

Figura 5: Super/Hipermercados por principais redes em São Paulo........................122

Figura 6: Fluxograma da distribuição de alimentos - 2009 ...................................124

Figura 7: Expansão Urbana em São Paulo ......................................................130

Figura 8: Restaurantes (131) da 1ํ edição do Guia 4 Rodas (1966).......................155

Figura 9: Restaurantes (363) da última edição do Guia 4 Rodas (2011) ................155

Figura 10: Procedimentos da pesquisa qualitativa .............................................233

Figura 11: Seleção do público restaurantes ....................................................236 



\section{SUMÁRIO}

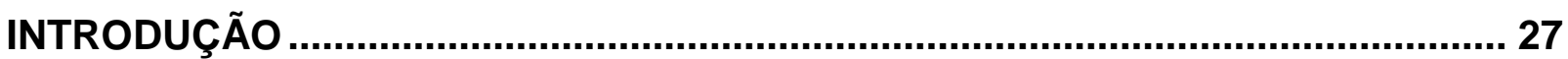

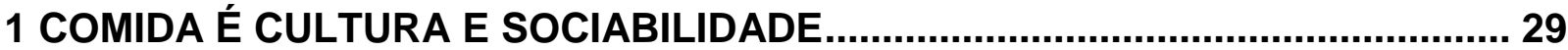

2 MATRIZES RACIAIS E A CULINÁRIA BRASILEIRA ..........................................39

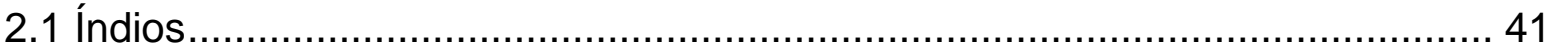

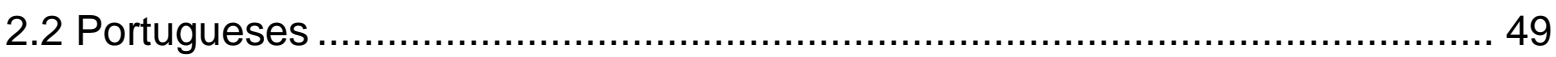

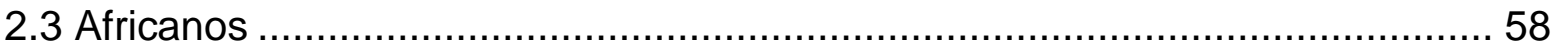

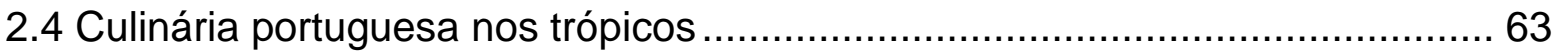

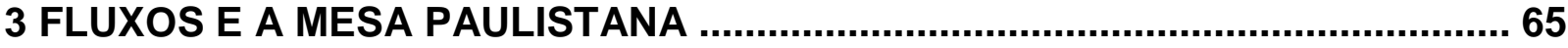

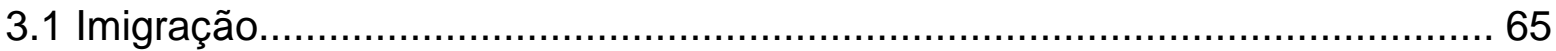

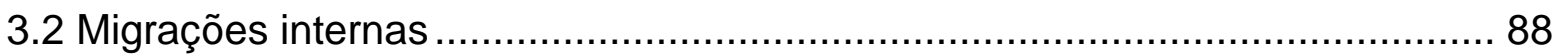

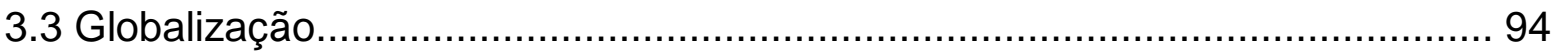

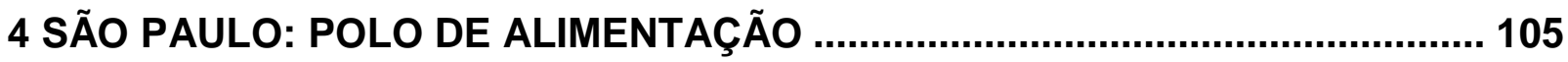

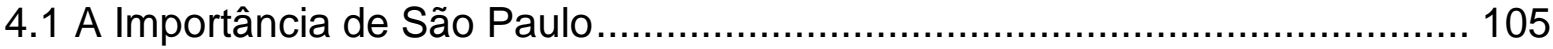

4.1.1 Indicadores sociodemográficos e negociais ....................................... 106

4.1.2 IPC - Índice de Potencial de Consumo ................................................ 108

4.2 Visão da cadeia alimentar ...................................................................... 110

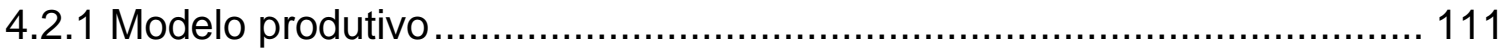

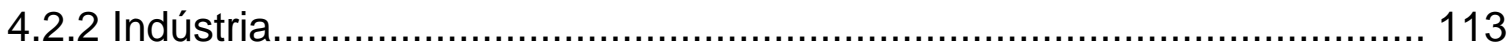

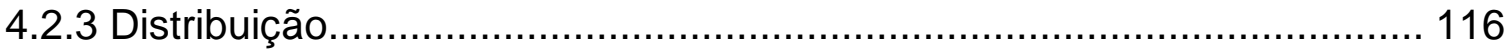

4.3 Variáveis impactantes no consumo de alimentos...................................... 126

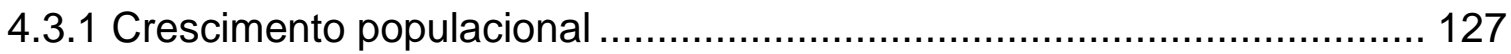

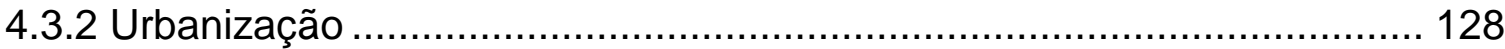

4.3.3 Estrutura etária e familiar ............................................................... 131

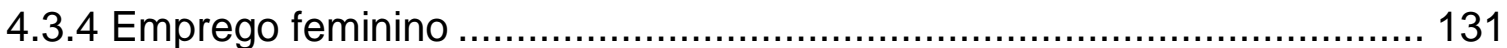

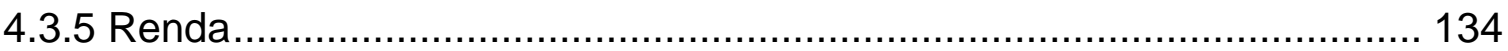

4.3.6 Educação e informação............................................................... 135

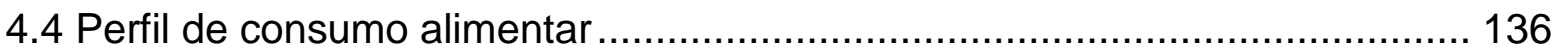

4.4.1 Comparação do consumo no tempo …………….............................. 137

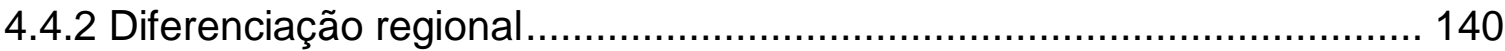




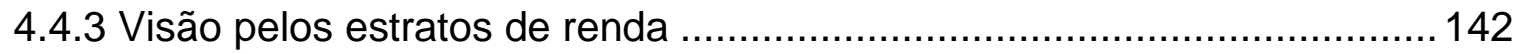

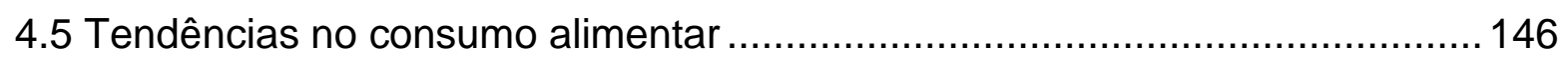

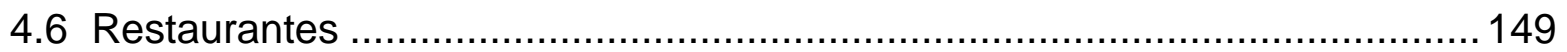

5 APRESENTAÇÃO DOS RESULTADOS DA PESQUISA …................................157

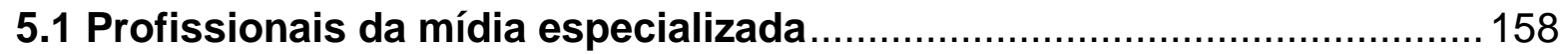

5.1.1 Mudanças no mercado de alimentação na cidade de São Paulo ............. 158

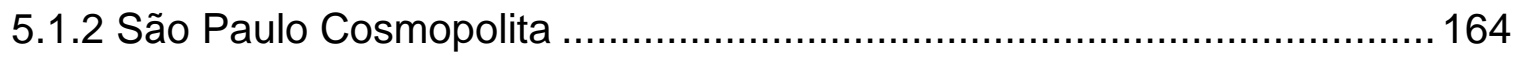

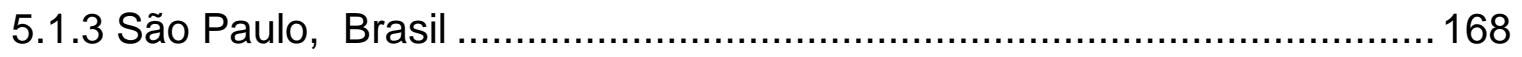

5.2 Chefs e proprietátios de restaurantes ……........................................ 174

5.2.1 Mudanças no mercado de alimentação na cidade de São Paulo ............. 174

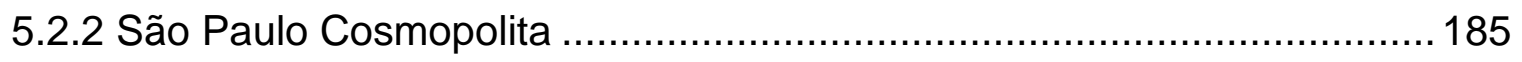

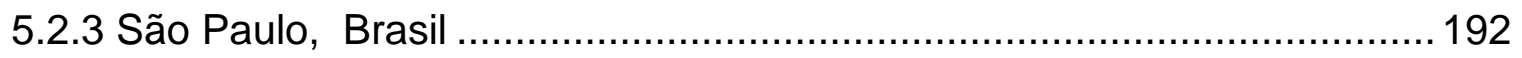

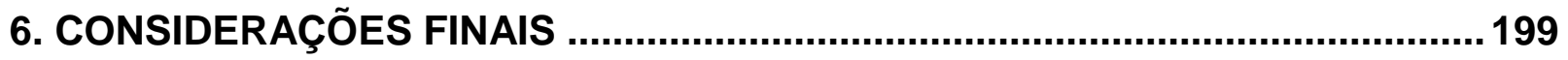

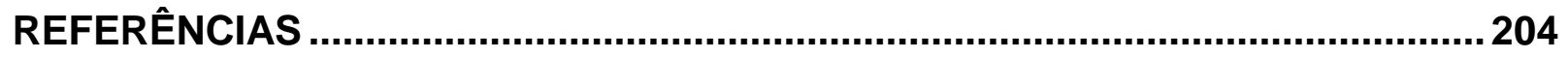

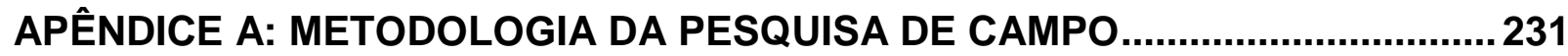

ANEXO A: AQUISIÇÃO ALIMENTAR DOMICILIAR ANUAL EM SÃO PAULO (ENDEF 1974/1975 - POF 2008/2009) ................................................243

ANEXO B: AQUISIÇÃO ALIMENTAR DOMICILIAR ANUAL -

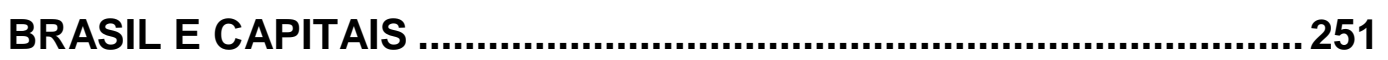

ANEXO C: AQUISIÇÃO ALIMENTAR DOMICILIAR ANUAL POR CLASSE DE RENDIMENTO 


\section{INTRODUÇÃO}

Este trabalho parte do entendimento de que a comida exerce papel fundamental na vida das pessoas não somente como meio de se nutrirem e garantirem a sobrevivência, mas pela carga cultural que carrega consigo e por seu aspecto de sociabilidade.

A relevância da alimentação faz-se notar ainda no campo econômico, por meio da dimensão desse mercado, tanto no âmbito da produção quanto da distribuição e do consumo. Nesse contexto, a cidade de São Paulo se destaca ao constituir-se como o maior mercado de alimentação não só do Brasil mas de toda a América Latina.

No que se refere à diversidade, é essencial remontar à formação da mesa paulistana, que remete ao passado colonial do país, somado aos fluxos imigratórios e migratórios com destino à cidade, dando origem a uma população fortemente mestiçada que contribuiu para sua expressiva variedade gastronômica.

Do ponto de vista econômico a magnitude e a importância do mercado de alimentação na cidade de São Paulo expressa-se pelo número de estabelecimentos que congrega, a saber, 4,5 mil padarias, 3 mil açougues, 3,4 mil supermercados e 12,5 mil restaurantes; devendo-se observar ainda sua posição de destaque no contexto internacional como uma das maiores metrópoles do mundo (GEOGRAFIA DE MERCADO, 2010; ABRASEL, 2009).

Tendo esse cenário como pano de fundo, o objetivo geral deste trabalho é apresentar a comida como um elemento plural e dinâmico dentro da sociedade, explorando aspectos culturais, econômicos e sociais, destacando São Paulo como o maior mercado de alimentação e principal polo gastronômico do país, em cuja formação da imagem os restaurantes têm papel de destaque. Desdobram-se daí os seguintes objetivos específicos:

.. Estudar influências formativas da mesa brasileira e paulistana;

.. Verificar o aproveitamento de atributos culturais e territoriais regionais no contexto da gastronomia; 
.. Apresentar entendimentos e percepções de chefs e proprietários de restaurantes e jornalistas especializados, formadores de opinião, sobre a gastronomia paulistana;

.. Fomentar uma reflexão sobre a imbricação entre o local e o global no contexto da alimentação em São Paulo.

Para a consecução dos objetivos supramencionados foi realizada inicialmente uma pesquisa bibliográfica e a demais fontes secundárias, sendo abordados no primeiro capítulo aspectos da comida como cultura e sociabilidade, apresentando-a como um elemento dinâmico dentro da sociedade, dotado de significados desde os primórdios da humanidade.

Outro aspecto da pesquisa buscou discutir o entendimento da culinária brasileira a partir da relação entre índios, portugueses e africanos, evidenciando o estabelecimento de uma relação de hierarquia e poder, conforme apresentado no capítulo dois.

No capítulo três foram analisadas as influências dos intensos fluxos migratórios e imigratórios, destacando-se contribuições desses grupos na formação de uma mesa miscigenada que caracteriza a cidade de São Paulo, e discutidos os impactos da globalização no âmbito da gastronomia, remarcando-se a utilização de atributos culturais e territoriais como elemento de diferenciação diante da tendência de homogeneização do mercado.

O capítulo quatro destaca a cidade de São Paulo como polo de alimentação, posicionando-a como líder econômico dentro do país, salientando variáveis que impactam o consumo das famílias e apresentando uma visão da cadeia alimentar.

Complementarmente, foi desenvolvido um levantamento de dados primários operacionalizado com base em entrevistas com jornalistas e profissionais de destaque na área gastronômica da cidade de São Paulo, por intermédio das quais se buscou mapear entendimentos e percepções sobre a gastronomia paulistana, os quais estão apresentados no capítulo cinco. A metodologia desse levantamento de campo está detalhada no apêndice $A$.

O capítulo seis reúne considerações finais da autora sobre os temas discutidos ao longo do trabalho, retratando também algumas das limitações deste estudo e possíveis desdobramentos temáticos. 


\title{
1 COMIDA É CULTURA E SOCIABILIDADE
}

\begin{abstract}
Saber por que maneira um povo come é penetrar na sua vida íntima, conhecer o seu gosto, apreciar o seu caráter. Hoje em dia, comer já não é como outrora - alimentar-se. Comer é revelar-se. Os povos modernos têm os seus alimentos prediletos, como têm as suas canções, as suas danças e seus jogos favoritos, e, segundo o que eles comem, assim se pode freqüentemente estabelecer o seu modo de ser e de pensar (CHAGAS, 1977, p. 46).
\end{abstract}

A comida desempenha importante papel na vida humana, nas sociedades e no contato entre povos distintos no curso da história; adquirindo, ao longo do tempo, novos contornos e significados (FLANDRIN; MONTANARI, 1998; LAUDAN, 2000; SANTOS, 2005; POULAIN, 2004; LEONARD, 2002; CARNEIRO, 2006; MENESES; CARNEIRO, 1997; DÓRIA, 2009b). O ato de comer suplanta a satisfação da necessidade básica vital, ou seja, vai além da subsistência e da nutrição, carregando consigo uma imensa carga cultural (LÉVI-STRAUSS, 2004; BOURDIEU, 2007; BRILLAT-SAVARIN, 1999; CERTEAU; GIARD; MAYOL, 2005).

O gosto, ao mesmo tempo em que pode ser entendido como sabor, constitui também um saber. Se por um lado, como sensação da língua e do palato, ele é uma experiência individual e subjetiva, por outro é condicionado pela avaliação sensorial, coletiva e comunicada que vem do cérebro. Em outras palavras, uma comida não é considerada boa ou ruim por si só, mas também porque se aprendeu a reconhecê-la como tal (BOURDIEU, 2007; MONTANARI, 2008).

$\mathrm{Na}$ mesma linha de pensamento, This (2005), ao teorizar sobre o tema, afirma que o gosto é

o conjunto de sensações gustativas (sabor), olfativas (odores e aromas), mecânicas, proprioceptivas, térmicas... é o gosto que, uma vez percebido de modo psicológico, é interpretado pelo cérebro, o qual associa a ele qualidades conforme as experiências individuais e sociais (lembranças, emoções, aprendizagens, etc.).

Trata-se, então, de "uma experiência de cultura que nos é transmitida desde o nascimento, juntamente com outras variáveis que contribuem para definir os 'valores' de uma sociedade", conforme afirma Montanari (2008, p. 95). Assim, como destacam Morais e Silva (2002, p. 379), conhecer em profundidade os hábitos alimentares de um povo ultrapassa a alimentação em si: 
Refletir sobre a alimentação de um povo exige um exercício de resgate e um olhar sobre o seu modus vivendi - passado e presente reunindo elementos de identidade e organização econômica e social dos indivíduos, crenças religiosas, inserção histórica e geográfica, aspectos etnográficos que transpõem os limites da necessidade fisiológica do ato de comer e se nutrir.

A esse respeito, Brillat-Savarin (1999, p. 15) sintetiza em uma paródia: "digame o que comes, que eu te direi quem és".

A escolha, a preparação, a maneira de servir e o consumo dos alimentos refletem a terra, seus meios de produção, sua situação política e econômica, as influências culturais sofridas, a educação, as crenças religiosas, entre outros (CERTEAU; GIARD; MAYOL, 2005). Justamente por isso, Weis (2009, p. 14) situa o estudo histórico dos alimentos "na intersecção do material e do social, da vida cotidiana e dos grandes esquemas políticos e culturais".

Embora ainda não se saiba exatamente quando os homens passaram a escolher seus alimentos e tampouco as regras que seguiram os diferentes grupos humanos para tal seleção, é possível perceber que, no decorrer dos anos, os homens não somente encontraram diferentes alimentos nas diversas regiões do globo, como também procederam de maneira distinta na escolha e manejo dos alimentos ofertados pela natureza (FLANDRIN, 1998, p. 29).

Os faz-mal alimentares e os interditos são exemplos interessantes nesse sentido. Existentes desde os primórdios da humanidade, ligados ou não à religião, fazem-se presentes na vida de todos os povos, condicionando as dietas e complementando os temperos na história da alimentação (LIMA, 1999; STEINGARTEN, 2000; FLANDRIN, 1998; SOLER, 1998).

A alimentação dos primeiros homens ainda não foi totalmente desvendada, mas não parece diferenciar-se muito da de outros mamíferos. Acredita-se que se nutriam essencialmente de frutos, hortaliças e grãos coletados da natureza, sendo que, posteriormente, incluíram raízes, a cuja procura provavelmente se dedicavam as mulheres (UNB, 2010). Estudos arqueológicos indicam que a carne também já fazia parte da alimentação dos primeiros hominídeos; porém, não há consenso sobre eles terem sido caçadores ativos ou ladrões de carcaças (PERLÉS, 1998, p. 38).

O domínio do fogo, que se deu por volta de 500 mil a.C., e o desenvolvimento de instrumentos abriram caminho para a mudança dessa realidade. Cumpre lembrar que o interesse pela carne cozida não pode ser atribuído 
exclusivamente à espécie humana e nem mesmo ao domínio do fogo, já que animais frequentemente se alimentam de carnes assadas depois de incêndios. No entanto, não se pode negar os avanços e a ampliação de possibilidades que essa passagem representa para a alimentação humana (FLANDRIN, 1998, p. 30). Para Montanari (2008, p. 56), "as modificações químicas provocadas pelo cozimento e pelas combinações de ingredientes permitem levar à boca um alimento, se não totalmente 'artificial', seguramente fabricado".

O fogo adquire particular importância também no campo simbólico, adquirindo novos significados com o passar dos anos nas diversas sociedades, conforme demonstra Lévi-Strauss (2004; 2009) ao opor o cru e o cozido - natureza e cultura - seja ao constituir seu triângulo culinário ${ }^{1}$, seja ao debruçar-se sobre os mitos de índios americanos como os Bororo.

Até o final do período paleolítico os grupos humanos de todo o globo viviam como nômades, pois, apesar de dominarem o fogo e praticarem a caça e a pesca, desconheciam a agricultura e a domesticação de animais (UNB, 2010). Foi somente no período mesolítico que tais práticas passaram a ser exercidas no Oriente Médio, possibilitando a constituição das primeiras vilas. Dali, essas atividades espalharamse rapidamente para outras regiões mediterrâneas; porém, nas zonas mais ao norte, caça e coleta continuaram a compor a base da alimentação até mesmo depois da Era Cristã (FLANDRIN, 1998; PERLÉS, 1998), o que dá indícios da variedade da alimentação nas diferentes zonas, tanto decorrentes de questões morfoclimáticas, quanto das técnicas e utensílios disponíveis ou até mesmo das crenças de determinado povo.

\footnotetext{
${ }^{1}$ Triângulo Culinário de Lévi-Strauss:
}

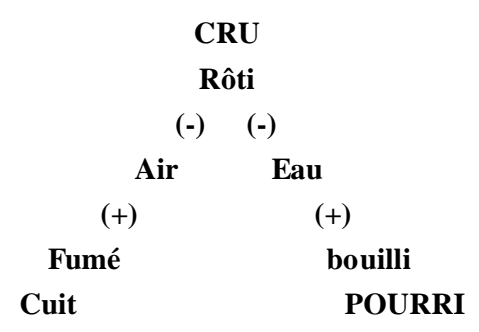

Figura 1: Triângulo culinário de Lévi-Strauss

Fonte: Adaptado de Lévi-Strauss (2009, p. 17). 
O período neolítico, conhecido como idade da pedra polida e idade dos metais, foi marcado por consideráveis transformações, entre as quais se podem mencionar o desenvolvimento e difusão da agricultura e da criação de animais e o emprego do sal, inicialmente extraído da ardósia (SENAC, 1998).

Ademais, é nessa fase que se inicia a cultura de cereais (como trigo, centeio, cevada e arroz), os quais vieram consolidar a base da alimentação humana até os dias atuais. Notam-se amplas diferenças na alimentação desse período, sobretudo nas zonas temperadas, talvez reflexo do desaparecimento da caça de grande porte que no período glacial era bastante abundante, o que vai ter forte impacto naquelas sociedades (PERLÉS, 1998).

Não obstante a intensificação da atividade humana sobre a natureza ter propiciado o aumento da população e a formação de grupos maiores (adensamento populacional), a maior dependência do solo exigiu maior tempo dedicado à alimentação, além de criar novos hábitos, como a instalação de mobiliários para dormir e guardar alimentos e, ainda, novos utensílios para comê-los e prepará-los, a exemplo das cerâmicas sobre o fogo e do forno de barro compactado. A partir desse momento, o alimento pôde ser preparado com antecedência, não sendo mais necessário aguardar a chegada da carne recém-caçada. Foi nessa época que os caldos passaram a integrar a alimentação humana, abrindo espaço para uma série de novas preparações (SENAC, 1998).

Na região do Egito, o trigo era cultivado desde ao menos três mil anos a.C. e com ele já confeccionavam-se os pães, considerados uma referência cultural dessa civilização, visto que a expressão "comedores de pão" era sinônimo de homens na língua de Homero (MONTANARI, 1998, p. 111). Na Grécia, por sua vez, o trigo dividia espaço com a cevada na base cerealífera da alimentação, o que Ihes rendeu a fama de "comedores de cevada" entre os romanos daquela época (AMOURETTI, 1998, p. 145). Na China, foi o arroz que, por volta de 2.800 a.C., consolidou-se como a planta e o alimento sagrado do imperador chinês, tendo se espalhado dali para 0 resto do globo (UNB, 2010). Assim, atentando para a adoção dos diferentes cereais pelos diversos grupos, pode ser percebida a diferenciação das dietas regionais. $\mathrm{Na}$ antiguidade, aparecem também registros do cultivo de outros grãos, além do consumo de queijos, hortaliças, condimentos e vinho, que se consolidou como a bebida da época, tanto na Grécia quanto em Roma (SENAC, 1998; MONTANARI, 1998). 
Embora não haja muitos registros sobre como alimentavam-se os homens comuns no Egito nesse período, travessas, alimentos e listas de oferendas encontradas em tumbas dão indícios de uma rica e farta alimentação entre os faraós, que incluía itens como pão, farinha, laticínios, gordura, carnes e peixes salgados, sal, cebola, alho e especiarias. Para os egípcios, os prazeres da mesa já eram associados à saúde e à longevidade, enquanto a inapetência era sinal de doença (BRESCIANI, 1998). A associação entre alimentação e saúde pode igualmente ser verificada em outras partes do mundo, da mesma forma que moldou as dietas nos milênios seguintes (LAUDAN, 2000).

Nesse sentido, médicos como os célebres Hipócrates (da Grécia Antiga) e Galeno (principal figura da medicina romana) destacavam os efeitos terapêuticos e preventivos da alimentação, associando-a ao combate a doenças (AMOURETTI, 1998; ASFORA, 2010).

No que tange à cultura alimentar do denominado "mundo clássico", porém, o aspecto mais significativo, ou ao menos um dos mais marcantes, é o propósito de apresentá-lo "como o domínio da civilização, como uma zona privilegiada e protegida, em oposição ao universo desconhecido da barbárie" (MONTANARI, 1998, p. 108). Nesse contexto, o regime alimentar desempenhou um papel fundamental no processo de definição do que seria um modelo de vida civilizado, que deveria fundamentar-se em três valores, a saber: a comensalidade, os tipos de alimentos consumidos, a cozinha e a dietética, os quais parecem consagrar a humanização das condutas alimentares (MONTANARI, 1998).

Como indica SCHUTLER (2003, p. 13): “A alimentação é um processo no qual o ser humano é sociabilizado desde o seu nascimento". Sob a mesma ótica, Lima (1999, p. 155) enfatiza:

\footnotetext{
De todos os atos naturais, o alimentar-se foi o único que o homem cercou de cerimonial e transformou-o, lentamente, em expressão de sociabilidade, ritual político, aparato de alta etiqueta. Compreendeu-lhe a significação vitalizadora e fê-la uma função simbólica de fraternidade, um rito de iniciação para a convivência, para a confiança na continuidade dos contatos. Comer é uma forma de entendimento, de irmanação.
}

Realmente, compartilhar o alimento é uma forma de irmanação. O termo companheiro se origina do latim companionem, composto por cum e panis, que significa "comer o pão com" ou partilhar o pão (VIANA, 2010; CASCUDO, 2004). Da 
mesma maneira, beber na mesma taça estabelece a fraternidade entre todos, e o sal partilhado durante a refeição simboliza o laço entre duas pessoas, tanto é que na época neoassíria a relação de amizade é referida como o "homem do meu sal" (amelu sa tabtiya) (JOANNÉS, 1998, p. 57).

Por conseguinte, repartir o alimento é aproximar-se de uma pessoa, sendo que a constituição do núcleo familiar já estava diretamente ligada a essa ideia. Como destaca Ishige (1987, p. 20): "a família começou a existir desde que se estabeleceu uma relação sexual estável entre um homem e uma mulher ligados pela partilha de alimentos (...) é por isto que, em muitas culturas, a lareira e o forno onde se prepara a comida se converteram em símbolo da família".

De acordo com o que foi exposto, observa-se que a alimentação é comumente associada à confraternização. Assim, em diversas sociedades e em diferentes períodos históricos, as celebrações rituais são acompanhadas por banquetes, constituindo ocasiões em que se reforçam ou se criam laços.

Nas primeiras civilizações, como é o caso da Mesopotâmia, nota-se com clareza a ampla função social das refeições e dos banquetes, sejam reuniões de particulares, banquetes reais ou com funções religiosas. O banquete de núpcias, por exemplo, é que legitima o casamento na Assíria no terceiro milênio (JOANNÈS, 1998, p. 56).

O banquete constitui, pois, símbolo de identidade do grupo daqueles que se reúnem em torno de uma refeição comum, contribuindo para sua coesão. No entanto, não se apresenta somente como referência de unidade e agregação, mas igualmente de separação e marginalização.

Segundo o mecanismo antropológico do dom e da contrapartida, o banquete é, ainda, espaço no qual se expressam diferentes valores sociais (MAUSS, 1974) que dependem da posição daquele que oferece: de baixo para cima, de cima para baixo ou no mesmo plano (ISHIGE, 1987).

De igual maneira, as hierarquias podem manifestar-se de acordo com a posição na mesa, com a ordem de servir e com aquilo que se come. Nesse sentido, Crompton (1993) aponta o gosto como "um recurso que é organizado por grupos no interior do sistema de estratificação a fim de estabelecer ou consolidar sua inserção na ordem social" (CROMPTON, 1993, p. 171). Na mesma linha, Bourdieu (2007) afirma que os atores sociais fazem uso estratégico do gosto como maneira de 
demarcar socialmente grupos e obter reconhecimento simbólico e prestígio, considerando o gosto uma forma cultural de escolha e preferência.

De modo semelhante, as práticas de cozinha não podem ser tomadas como ideologicamente neutras, uma vez que expressam questões culturais, sociais e até contraposições de gênero. Nessa perspectiva, pode-se mencionar a distinção entre o cozido e o assado. O assado está mais próximo da natureza e do selvagem, do domínio imediato sobre as forças naturais, da figura masculina, do caçador, na medida em que o cozido une o uso do recipiente - que é um artefato cultural - à realidade da conveniência e da rentabilidade (pois não se desperdiçam os sucos nutritivos da carne), remetendo ao camponês e à mulher, visto que a "panela que ferve sobre o fogo faz parte das competências femininas" (MONTANARI, 2008, p. 80).

Da mesma forma, o modo de servir e de combinar os alimentos, a ordenação dos pratos, a disposição de objetos, o sentar-se à mesa ou não e os rituais que circundam as refeições são elementos que refletem a organização social e desvendam costumes e crenças. Reunidos, são o reflexo de um lugar, de um grupo específico de pessoas, em determinado tempo.

Montanari (2008, p. 96) explica que "Assim como há gostos e predileções diversos em diferentes povos e regiões do mundo, assim os gostos e predileções mudam no decorrer dos séculos". Do ponto de vista das transformações temporais, Bloch (1949, p. 20) destaca o provérbio árabe que diz: "Os homens se parecem mais com seu tempo do que com seus pais".

Nesse sentido, Laudan (2000) associa o nascimento da dieta ocidental moderna ao Século XVII. Para ela, até aproximadamente 1650 as elites islâmicas e cristãs compartilhavam quase a mesma dieta, composta por purês grossos, muitas especiarias, molhos agridoces, vegetais cozidos e vinhos amornados.

A chave da hegemonia e da transformação estaria ligada à dietética e à nutrição, à história da química e à da medicina, as quais encontravam raízes comuns na Antiguidade, na que ficou conhecida como dieta hipocrática-galênica e que, nesse período, estava passando por transformações (LAUDAN, 2000).

Até então, acreditava-se que o equilíbrio do corpo deveria ser mantido por meio de uma dieta balanceada que, de modo semelhante ao temperamento ideal humano, deveria ser ligeiramente morna e levemente úmida, de sorte que coubesse 
ao chef escolher os ingredientes e preparar a refeição de acordo com cada comensal (ASFORA, 2010; LAUDAN, 2000).

Os fisiologistas europeus do Século XVII, no entanto, passaram a compreender o processo digestivo de uma forma diversa, que fundamentaria um novo modelo alimentar, baseado em três elementos: mercúrio (não o elemento químico, mas a essência dos fluidos voláteis responsáveis pelos cheiros e aromas), enxofre (não o elemento químico, mas a essência das substâncias oleosas, o amálgama das preparações, que aporta umidade e doçura) e o sal (não o sal de mesa, mas a essência dos sólidos, a qual ditava o sabor e a consistência dos alimentos) (LAUDAN, 2000).

Paralelamente, o açúcar foi considerado perigoso e, por isso, direcionado para a periferia das refeições, ou seja, para a sobremesa. Os chefs também passaram a preparar caldos (ou essências) de carne e peixe considerados restauradores. Por sua vez, alguns empreendedores da época vislumbraram a oportunidade de vendê-los em tabernas para aqueles que não podiam pagar por um especialista em casa, o que seria apontado por alguns como a origem dos restaurantes (LAUDAN, 2000), embora haja trabalhos detalhados sobre o tema que contrariem tal teoria (SPANG, 2003). "Eventualmente, então, a classe média europeia emulou a aristocracia, desenvolvendo um gosto não somente pelos 'restaurants', mas também pela nova cozinha", que gradualmente espalhou-se pela Europa e traçou seu caminho na direção das escalas sociais mais baixas (LAUDAN, 2000, p. 81).

Dessa forma, segundo Montanari, somente na França dos Séculos XVII e XVIII surgiu a noção de que a cozinha devia respeitar o sabor natural de cada alimento. O gosto romano antigo, medieval, seguiu uma lógica muito mais sintética do que analítica, pois manteve um modelo de cozinha baseado principalmente na ideia de artifício e na mistura de sabores (MONTANARI, 2008).

Interessante notar que a cozinha que nasceu no Século XVII viveu muito além da teoria que a inspirou. Já no final do Século XVIII, os químicos e fisiologistas deram início às pesquisas que desembocaram nas teorias modernas sobre calorias, carboidratos, vitaminas, proteínas e minerais.

Nesse sentido, Dória (2009b) aponta para a existência de uma "memética das receitas". Seguindo os princípios de Richard Dawkins (apud Dória, 2009b), para quem os memes seriam "uma unidade de transmissão cultural, ou uma unidade de 
imitação", Dória afirma que a receita é um "meme", na medida em que não existe necessariamente um questionamento ou uma verificação das precisions contidas nos enunciados das mesmas (não existe necessariamente a preocupação com a validação científica dos ensinamentos ali contidos) para que sua continuidade se processe, de geração em geração.

Pode-se dizer que "a cozinha vem acompanhando o homem através dos tempos, misturando ingredientes, técnicas, usos e costumes, regras morais e religiosas, aspectos geográficos, políticos e sociais” (SENAC, 1998, p. 98) e que, juntamente com ele, vem se transformando continuamente.

Fica claro que a comida é social e culturalmente significativa, distinta, portanto, da experiência estritamente fisiológica de alimentar-se (GONÇALVES, 2004, p. 45). Isto é, os seres alimentam-se não somente de nutrientes, mas também - quiçá sobretudo - de imaginário e de significados (FISCHLER, 1995).

Como afirma Da Matta (1986), a "comida não é apenas uma substância alimentar, mas é também um modo, um estilo e um jeito de alimentar-se. E o jeito de comer define não só aquilo que é ingerido, como também aquele que o ingere".

Acrescenta-se que a cozinha vem sendo equiparada à linguagem, tanto no plano técnico-estrutural quanto como sistema portador de valores simbólicos. Assim como a linguagem, ela "contém e expressa a cultura de quem a pratica, é depositária das tradições e das identidades do grupo" (MONTANARI, 2009a, p. 11). Ambas são excelentes veículos de comunicação e autorrepresentação.

Para Schwarcz (2010, p. 9-10):

Da mesma maneira como não existe sociedade sem linguagem, também não é possível pensar em um agrupamento humano que não cozinhe, ou melhor, que não elabore os seus próprios alimentos. Por isso mesmo, nenhum alimento é simplesmente cru e pronto, ou simplesmente cozido. Cada sociedade, também, se expressa e fala de si na maneira como arranja a comida e nas formas como faz do alimento um discurso, ou até mesmo uma representação.

Assim, se em um nível mais concreto simplesmente comemos - temos fome e nos saciamos-, de maneira mais abstrata produzimos valores e sentidos quando pensamos estar apenas lidando com a nossa satisfação e mera sobrevivência. Tudo isso porque o homem não sobrevive apenas, mas antes inventa significados para tudo que faz.

Ainda, se a aproximação é recente para alguns, é interessante destacar que na escrita hieroglífica, no Egito Antigo, um mesmo signo - um homem levando a mão à boca - designa tanto "falar" quanto "comer" (BRESCIANI, 1998, p. 68). 
Vale lembrar também que provar de um alimento advindo de outro lugar parece mais simples do que decodificar uma língua, o que faz da comida mais do que um instrumento de identidade cultural, mas talvez o primeiro elemento de contato entre culturas distintas (MONTANARI, 2009a).

Sobre essa relação estabelecida entre culturas distintas, Kopytoff (1986, p. 67) pontua que "o que é mais significativo sobre a adoção de objetos estrangeiros como de ideias estrangeiras - não é o fato de eles os adotarem, mas o modo como eles culturalmente redefiniram e os colocaram em uso".

Nesse sentido, Montanari (2009b, s. 42), ao discorrer sobre o tema da identidade alimentar, conclui que "quanto mais fundo se vai à busca pela raiz da nossa identidade, que por sua vez corresponde àquilo que somos hoje, mais os outros que vivem em nós se multiplicam, mais clara fica a miscigenação cultural que nos acompanha desde os primórdios".

Assim, deve-se atentar para o fato de que não existe identidade ou culinária atemporal, mas que elas estão sujeitas a transformações constantes. Sobre o tema, Maciel (2004, p. 27) afirma:

\begin{abstract}
A cozinha de um povo é criada de um processo histórico que articula um conjunto de elementos referenciados na tradição, no sentido de criar algo único - particular, singular e reconhecível. Entendendo a identidade social como um processo relacionado a um projeto coletivo que inclui uma constante reconstrução, e não como algo dado e imutável, essas cozinhas estão sujeitas a constantes transformações, a uma contínua recriação.
\end{abstract}

Desse modo, parece fundamental para o desenvolvimento deste trabalho selecionar alguns fragmentos da história do Brasil e de São Paulo, que possam servir como base para a reflexão sobre a constituição da oferta gastronômica e a construção de identidades alimentares e seus estereótipos ${ }^{2}$, assim como sobre a imbricação entre o local e o global que aí toma forma.

\footnotetext{
${ }^{2}$ O termo estereótipo está sendo utilizado no decorrer deste trabalho como clichê, "impressão sólida", para designar uma imagem que é fixada. (MARTINEZ, 2010).
} 


\section{MATRIZES RACIAIS E A CULINÁRIA BRASILEIRA}

Existe bastante complexidade quando se pretende definir ou mesmo caracterizar a comida brasileira; pois, assim como o seu povo, ela é bastante diversificada. Não há, como afirma Bosi (1987), uma cultura brasileira, mas sim culturas brasileiras. Culturas que se encontram, se misturam e se fundem, fazendo emergir uma identidade plural, multifacetada (ORTIZ, 2006; HALL, 2006; BAUMAN. 2005).

Trata-se de um país com extensas dimensões continentais, no qual se cristalizam marcas regionais e evidenciam-se, entre tantos outros aspectos, a diversidade de cores, aromas, sabores, texturas, modos de preparo e influências sofridas nas diversas localidades, por distintos grupos de pessoas. Vários autores já exploraram essa diversidade alimentar em suas obras, convidando a verdadeiras viagens através do Brasil - como Caloca Fernandes (1998), Ofélia Anunciato (1996), Antônio Houaiss (1990), Christopher Idone (1995), Sílvio Lancelotti (2000), Eda Romio (2000), Pedro Cavalcanti (2007), Carla Barboza Pinto (1998), Ana Luiza Trajano (2005), Cozzolino, Fiesberg e Wheba (2002), entre outros. Contudo, ainda há muito a ser estudado.

Uma possibilidade para refletir sobre tal diversidade seria desmembrar diversas preparações da atualidade e, ao buscar suas origens, tentar decifrar o processo histórico, pontuar as relações estabelecidas no tempo e no espaço, as influências sofridas e vislumbrar como a tradição e a inovação vêm se interrelacionando no território nacional. Contudo, não há neste trabalho a intenção de se deter propriamente nas preparações encontradas nos receituários brasileiros, mas de apontar como os diversos fluxos e as relações que vão se delineando influenciaram e contribuíram, ao longo desses mais de "500 anos de povoamento e despovoamento"3, para a formação e para o dinamismo dessa mesa miscigenada que lhe é característica.

\footnotetext{
3 A expressão "500 anos de povoamento e despovoamento" é utilizada por Vainfas (2000) na introdução do livro Brasil: 500 anos de povoamento.
} 
Considerando tal intenção, faz-se necessário abordar o processo histórico da constituição do Brasil, partindo-se da relação estabelecida entre índios, portugueses e africanos no período colonial brasileiro.

$\mathrm{Na}$ bibliografia recente, é bastante comum que se entenda e se fundamente a culinária brasileira mediante a combinação das três matrizes raciais: índios, brancos (o europeu português) e negros (africanos) (CASCUDO, 2004; FREYRE, 1997; RIBEIRO, 2003). Estaria alicerçada nessa mistura a identidade alimentar do brasileiro, por vezes tomando como equivalentes suas contribuições, como se essas três matrizes tivessem convivido de igual maneira, no mesmo plano, ao longo desses mais de 500 anos.

Note-se que essa maneira de contar a história do nosso país começou a ganhar força somente no Século XIX (DÓRIA, 2009a; ORTIZ, 2006), quando estudos antropológicos passaram a ocupar papel central no pensamento intelectual. Acrescenta-se o fato de o estudo do naturalista alemão Von Martius - que destacava a fusão das três raças como eixo da formação histórica do Brasil - ter ganhado o concurso promovido pelo IHGB, em 1840, sobre como se deveria escrever essa história (VAINFAS, 2000).

De acordo com Ribeiro (2003, p. 19), a cultura brasileira surgiu do entrechoque do invasor português com índios silvícolas e campineiros e com negros africanos, tanto estes como aqueles aliciados como escravos:

\footnotetext{
Nessa confluência, que se dá sob regência dos portugueses, matrizes raciais díspares, tradições culturais distintas, formações sociais defasadas se enfrentam e se fundem para dar lugar a um povo novo (RIBEIRO, 1970), num novo modelo de estrutura societária. Novo porque surge como uma etnia nacional, diferenciada culturalmente de suas matrizes formadoras, fortemente mestiçada, dinamizada por uma cultura sincrética e singularizada pela redefinição de traços culturais delas oriundos.
}

Os primeiros registros do encontro estão na carta de Pero Vaz de Caminha, datada de primeiro de maio de 1500. Nos primeiros dias, a contar de 24 de abril, os índios não quiseram provar quase nada dos alimentos oferecidos pelos portugueses, como está relatado no texto:

Deram-Ihes, ali, de comer: pão e peixe cozido, fartéis, mel e figos passados. Não quiseram comer quase nada daquilo; e se alguma coisa provavam, logo a lançavam fora. Trouxe-Ihes vinho numa taça; mal lhe puseram a boca; não gostaram de nada, nem quiseram mais. Trouxe-lhes água em uma 
albarrada. Não beberam. Mal a tomaram na boca, que lavaram, e logo a lançaram fora (CAMINHA, s.d., p. 67).

Em sete dias de convívio, porém, os índios provaram vinho, pão de trigo, presunto, arroz, lacão, confeitos de açúcar, doce com ovos, passa de figos, entre outras iguarias. Os relatos destacam que os índios provaram muito mais do que ofereceram ou trocaram. Foram poucas as iguarias brasileiras que receberam algum destaque, das quais os portugueses nem quiseram saber os nomes no idioma local, batizando objetos e alimentos com títulos portugueses (CASCUDO, 2004).

Foram os portugueses, aliás, que transmitiram praticamente toda a informação existente sobre esse período da história do Brasil, não somente a respeito dos costumes e tradições indígenas, mas igualmente sobre a presença africana, reflexos do que Dória (2009a) e Montanari (2009a) caracterizam como disputas nada igualitárias entre as culturas orais e escritas, entre dominadores e demais.

\section{1 Índios}

Originários da Ásia e vindos para o continente americano por volta de $10 \mathrm{a}$ 12 mil anos A.C., foram chamados, a partir de então, de "povos ameríndios", espalhando-se por boa parte do território americano (VAINFAS, 2000, p. 40).

Não se sabe precisamente 0 tamanho da população que habitava 0 atual território brasileiro por volta de 1500, mas estima-se que era na casa dos milhões; enquanto hoje, se registram pouco mais de 300 mil indivíduos.

Os dados apresentados na Tabela 1 ilustram a grande baixa na população indígena em diversas áreas do país, podendo-se notar que no Estado de São Paulo, ela correspondia, em 1998, a pouco mais de $1,2 \%{ }^{4}$ daquela estimada no século XVI para alguns grupos selecionados (IBGE, 2000, p. 222).

\footnotetext{
${ }^{4}$ Deve-se ponderar, contudo, que tal número não observa a ancestralidade indígena da população brasileira em geral.
} 
Tabela 1: População indígena no Brasil

\begin{tabular}{|c|c|c|c|}
\hline \multicolumn{2}{|l|}{ Século XVI } & \multicolumn{2}{|l|}{1998} \\
\hline $\begin{array}{l}\text { Grupos indígenas } \\
\text { selecionados e localização }\end{array}$ & $\begin{array}{l}\text { Estimativas da } \\
\text { população } \\
\text { indígena }\end{array}$ & Unidades da Federação & $\begin{array}{c}\text { Estimativas da } \\
\text { população } \\
\text { indígena }\end{array}$ \\
\hline $\begin{array}{l}\text { Acre (Rio Purús) } \\
\text { Não menos de } 16 \text { grupos }\end{array}$ & 30.000 & Acre & 9.240 \\
\hline $\begin{array}{l}\text { Amazonas (Rio Branco) } \\
9 \text { grupos }\end{array}$ & 33.000 & Amazonas & 78.701 \\
\hline $\begin{array}{l}\text { Tocantins } \\
19 \text { grupos }\end{array}$ & 101.000 & Tocantins & 5.583 \\
\hline $\begin{array}{l}\text { Maranhão } \\
14 \text { grupos }\end{array}$ & 109.000 & Maranhão & 15.916 \\
\hline $\begin{array}{l}\text { Bahia } \\
8 \text { grupos }\end{array}$ & 149.000 & Bahia & 11.396 \\
\hline $\begin{array}{l}\text { Minas Gerais } \\
11 \text { grupos }\end{array}$ & 91.000 & Minas Gerais & 6.623 \\
\hline $\begin{array}{l}\text { Espírito Santo } \\
9 \text { grupos }\end{array}$ & 160.000 & Espírito Santo & 884 \\
\hline $\begin{array}{l}\text { Rio de Janeiro } \\
7 \text { grupos }\end{array}$ & 97.000 & Rio de Janeiro & 22 \\
\hline $\begin{array}{l}\text { São Paulo } \\
8 \text { grupos }\end{array}$ & 146.000 & São Paulo & 1.758 \\
\hline $\begin{array}{l}\text { Paraná e Santa Catarina } \\
9 \text { grupos }\end{array}$ & 152.000 & Paraná e Santa Catarina & 12.316 \\
\hline $\begin{array}{l}\text { Rio Grande do Sul } \\
5 \text { grupos }\end{array}$ & 95.000 & Rio Grande do Sul & 12.298 \\
\hline $\begin{array}{l}\text { Mato Grosso do Sul } \\
7 \text { grupos }\end{array}$ & 118.000 & Mato Grosso do Sul & 38.392 \\
\hline $\begin{array}{l}\text { Mato Grosso Central } \\
\text { Não menos de } 13 \text { grupos }\end{array}$ & 71.000 & Mato Grosso & 18.186 \\
\hline Outros grupos selecionados & 786.000 & Outras Unidades da Federação & 91.573 \\
\hline Total & 2.431 .000 & Total & 302.888 \\
\hline
\end{tabular}

Fonte: Adaptado de IBGE (2000, p. 222). 
A história do índio brasileiro é, conforme aponta Vainfas (2000, p. 37), um relato de despovoamento e "também de enganos e incompreensões". O próprio nome que the fora atribuído, índio, faz referência às Índias e foi aplicado indistintamente para designar os mais diversos grupos étnicos e troncos linguísticos aqui presentes (MONTEIRO, 1989). De maneira similar, os jesuítas chamavam os índios pelo coletivo gentio e referiam-se a eles como os negros da terra ou negros brasilis, aproximando-os dos africanos segundo a lógica colonialista da escravidão e do trabalho compulsório (VAINFAS, 2000).

As primeiras classificações, assim como outras mais ou menos minuciosas que surgiram com o tempo, são denominações sobretudo de origem missionária, resultantes de estudos que tinham por objetivo subjulgar, catequizar, escravizar, combater ou até mesmo, em alguns casos, se aliar aos índios (VAINFAS, 2000; BEOZZO, 1992).

Uma importante diferenciação que se evidencia é a que separa Tupis e Tapuias, sendo estes considerados como "os outros", ou seja, todas as nações ${ }^{5}$ indígenas não tupis. Note-se que os tupis estavam distribuídos por toda a costa brasileira no Século $\mathrm{XV}$, razão pela qual foi principalmente com eles que os portugueses relacionaram-se inicialmente (VAINFAS, 2000).

Com base nesses primeiros contatos e impressões, vários aspectos sobre 0 modo de vida indígena foram relatados. Por exemplo, o cardápio indígena, segundo Caminha, era regido pela presença de inhame, que era a base de sua alimentação. No entanto, o inhame é originário da Ásia (DÓRIA, 2009a) e foi trazido ao Brasil pelos portugueses (CASCUDO, 2004), sendo que o termo tem origem na África Ocidental.

Diante de tais fatos, é possível afirmar que o inhame ainda não havia chegado ao Brasil quando aqui desembarcaram os primeiros portugueses. De acordo com Cascudo (2004), o inhame nunca foi permanente na alimentação indígena, a raiz que alimentava o brasileiro era a mandioca ${ }^{6}$, seguida de batata e

\footnotetext{
${ }^{5}$ O termo nações era utilizado até pelo menos o Século XVIII para designar os estrangeiros que se diferenciavam pela língua, costume ou religião; mais do que demarcar identidades, proclamava alteridades (ORTIZ, 2006; VAINFAS, 2000).

${ }^{6}$ No Brasil, ficaram conhecidas como "mandioca" espécies do gênero Manihot. Em alguns lugares do país, no entanto, as variedades da Manihot utilissima foram designadas como macaxeira, aipim, mandioca-doce, entre outros; enquanto a Manihot esculenta é chamada de mandioca brava ou mandioca amarga.
} 
cará. A oferta de palmito, miolo das palmeiras, aos portugueses também suscita dúvidas. Teria sido o único fruto saboreado por Caminha, mas, segundo as descrições a respeito do deleite no instante seguinte à colheita, dificilmente deveria tratar-se de palmito. Provavelmente os índios "colheram das palmeiras alinhadas a caram da praya, cocos, folhas tenras, gomo folhear, brotos. Palmitos, strito sensu, é que não" (CASCUDO, 2004, p. 82).

Para Fausto (2000), o Brasil dos primeiros anos da colonização portuguesa era uma terra principalmente de tupis que se fortaleciam com a mandioca. Dória (2009a), por sua vez, chama atenção para o duplo padrão de carboidratos presente na dieta nativa, ao defender a hipótese de que os tupis-guaranis (que, segundo ele, foram os que ocuparam o Brasil da Amazônia até a Bacia do Prata através do Brasil Meridional, enquanto os tupinambás fizeram o mesmo percurso pelo leste) tinham no milho a principal base da alimentação.

São restritas as informações que chegaram aos dias atuais sobre a variedade da alimentação indígena em diversas partes do território. Mas além dos diferentes costumes, rituais e crenças de cada uma das nações indígenas, e dos instrumentos e técnicas que dominavam, as singularidades morfoclimáticas também servem para determinar e distinguir as fontes de alimentação, considerando que as espécies que existiam em algumas regiões não estavam presentes em outras, como é o caso das castanheiras, frequentes na Região Amazônica, mas não no restante do país. A dificuldade de compreender e perceber as particularidades alimentares de cada um dos grupos existentes naquela época parece reforçada ainda pelo fato de, conforme aponta Hermann (2000), diferentes grupos terem sido misturados e transportados de um lugar para outro como escravos, a partir do Século XVI, ou de terem migrado em fuga para outras áreas.

Pode-se acrescentar que, quando os portugueses aportaram no Brasil, os indígenas brasileiros já faziam uso do fogo para preparação de alimentos: assavam caças e pescas nas labaredas, sobre o calor das brasas, em moquéns, com espetos fincados a distância, em fornos subterrâneos ou na lapuna, utensílio muito usado que era uma espécie de forno para mandioca. Apesar de saberem extrair óleos de palmeiras e o fazerem para fins medicamentosos e embelezadores, os índios ignoravam a fritura, sendo seu alimento costumeiramente assado, tostado, ou "em menor escala cozido ou passado pela fervura" (CASCUDO, 2004, p. 84). 
A farinha (de milho ou mandioca, dependendo da região), por sua vez, era a base da alimentação local. Para Cascudo (2004, p. 93), "a farinha é a camada primitiva, o basalto fundamental na alimentação brasileira. Todos os elementos são posteriores, assentados na imobilidade do uso multicentenário, primário, instintivo".

Além da farinha de mandioca e de milho, os índios faziam também farinha de peixe seco, de macaxeira, de cará, de banana e de amendoim, dentre outras (STADEN apud SILVA, 2010). Um dado interessante é que o nome farinha deriva do latim farina, enquanto a mandioca e seus subprodutos, como beiju e tapioca, vêm do tupi. O beiju, aliás, reinante no mundo amazônico, tem ampla nomenclatura, variando de acordo com o preparo e condimentação. O beiju cica, por exemplo, é seco ao sol, enquanto o beiju membeca tem consistência mole, podendo conter leite de castanhas.

Outro aspecto curioso é que os indígenas não usavam sal, tendo como principal tempero as pimentas por eles cultivadas, que eram consumidas verdes, maduras ou secas. Segundo Cascudo (2004, p. 124), "não será no ângulo dos temperos que devemos muito à ciência cabocla da alimentação". Cultivavam também uma série de outros itens, como batata-doce, cará, feijão, amendoim, tabaco, abóbora, urucum, algodão, carauá, cuias e cabaças, abacaxi, mamão, ervamate, guaraná, além de árvores frutíferas como o caju, o pequi e as castanheiras (FAUSTO, 2000).

Para o cultivo, eram feitos grandes roçados na mata, derrubando-se as árvores com machados e limpando-se o terreno com queimadas. Segundo Silva (2010, p. 73), "a roça indígena era usada por dois a três anos, se não apresentasse problema de solo; ao final do primeiro ano, iniciava-se novo plantio em outra área, enquanto na primeira se fazia o replantio (exclusivamente com mandioca). Passados os três anos, a primeira roça era abandonada, ao mesmo tempo que já se iniciava o trabalho num terceiro campo, e assim por diante".

A agricultura assegurava fartura alimentar durante todo o ano e uma considerável variedade de matérias-primas, condimentos, venenos e estimulantes. Cultivavam-se e colhiam-se hortaliças, utilizadas para a preparação de diversos guisados e ensopados. Pela vasta extensão costeira e pela facilidade de acesso a rios, os pescados também eram abundantes. Se ocorresse exaustão de alimentos nos arredores das áreas cultivadas, migrava-se, temporária ou definitivamente, para outras (FAUSTO, 2000; VAINFAS, 2000). 
Interessante notar que os índios migravam de uma região para outra não só em busca de terras mais férteis, mas, a partir do início da colonização portuguesa, como forma de sobrevivência (em fuga) ou forçadamente (como escravos ou para aldeamentos). Assim, se o modo de vida dos indígenas não se modificou tanto nas primeiras décadas do Século XVI, as transformações foram substanciais a partir da década de 1530, quando começou de fato a colonização portuguesa (VAINFAS, 2000).

O próprio modelo de colonização escolhido para o Brasil, com a doação de 12 capitanias hereditárias a famílias ricas, às quais foi concedido também o direito de escravizar indígenas para exploração da terra, levava a tal procedimento. Os índios foram submetidos ao trabalho compulsório e tiveram sua realidade absolutamente transformada (BEOZZO, 1992). Até então, por exemplo, agricultura sequer era função masculina entre os indígenas, pois entre eles havia divisão de trabalhos por sexo, sendo atribuições femininas a agricultura (salvo a abertura dos roçados na mata), a preparação dos alimentos e o artesanato, enquanto caça, coleta e produção dos instrumentos e artefatos de guerra eram responsabilidades masculinas (VAINFAS, 2000).

Como alternativa ao trabalho compulsório, diversos grupos indígenas tornaram-se, no início da escravidão dos índios, fornecedores de mão-de-obra para a produção açucareira em troca de armas, o que fez, segundo Vainfas (2000, p. 45), "ativar a limites extremos a 'máquina da guerra' característica da cultura Tupinambá".

Com a consequente agravação da fragmentação existente entre as nações indígenas que ocupavam o território brasileiro naquela época, ou seja, com a falta de uma unidade cultural, os índios facilitaram o desmantelamento das diversas identidades culturais existentes (RIBEIRO, 2003). Alguns grupos aliaram-se aos portugueses para o fornecimento de escravos, proteção do território contra outros "invasores" e para servirem de guias para a própria exploração do território - a exemplo do famoso Tibiriçá. Paralelamente, outros uniram-se aos "inimigos" do projeto imperial ibérico - como franceses e holandeses - na tentativa de expulsá-los (HERMANN, 2000).

A chegada dos jesuítas, em 1549, se, por um lado poderia ser vista "como uma barreira à escravidão generalizada", de acordo com Vainfas (2000, p. 45), por outro lado, teve caráter igualmente destrutivo. A catequese buscava acabar com as 
identidades culturais indígenas por meio da imposição do catolicismo, ao mesmo tempo em que os aldeamentos, normalmente próximos a engenhos e vilas coloniais, eram verdadeiros viveiros de epidemias, espalhando doenças como varíola, gripe e sarampo, que dizimavam a população nativa (VAINFAS, 2000).

A alta lucratividade do comércio de escravos africanos ao final do primeiro século de colonização fez com que Portugal alterasse juridicamente sua postura em relação ao índio, coibindo sua escravidão em prol da disseminação da escravidão negra (BEOZZO, 1992). No entanto, apesar das leis e medidas régias que foram promulgadas entre o final do Século XVI e o início do XVII, o cativeiro indígena prosseguiu no litoral, diminuindo somente por causa do brusco declínio da população (MONTEIRO, 1989; VAINFAS, 2000).

Particularmente em São Paulo, a carência de braços para a lavoura e a falta de recursos que impediam a maioria paulistana de se valer de mão-de-obra africana levaram à expansão bandeirante (HOLANDA, 2010), fazendo com que a economia paulistana na virada do Século XVII girasse em torno da caça ao índio por meio das bandeiras (BEOZZO, 1992). Na região, visto que a cultura da cana não era suficientemente compensadora, a base agrícola era um esboço de policultura tocada pelo braço indígena (MONTEIRO, 1989; SILVA, 2010), o que, segundo Castro (1937), garantiu ao paulista uma maior diversidade e, portanto, qualidade na sua dieta alimentar quando comparada às áreas monocultoras.

A partir de meados do Século XVII, novas políticas em relação ao índio foram adotadas (MONTEIRO, 1989), tendo seu marco legal expedido na metade do século seguinte - o alvará de 4 de abril de 1755 - que aboliu a distinção jurídica entre índios e brancos, permitindo e até incentivando os casamentos entre brancos e índias; a partir de então estes não mais "perderiam seus privilégios, nem cairiam em infâmia, antes, seriam preferidos nas terras onde se estabelecessem com a família" (VAINFAS, 2000, p. 51).

Nesse mesmo ano, porém, instituiu-se o Diretório nos Estados do Maranhão e do Pará, tendo sido estendido para toda a América Portuguesa em 1758. Tratavase de uma nova política indígena, na qual cada povoado teria seu diretor nomeado pelo capitão-geral do Estado e, mediante essa política, houve a proibição definitiva da escravidão indígena e o fim da tutela das ordens religiosas nas aldeias (VAINFAS, 2000), sendo que ainda em 1759 foi decretada pelo Marquês de Pombal a expulsão dos jesuítas de todas as terras portuguesas (VILLALTA, 2002). 
Por intermédio do referido diretório estariam todos os nativos libertos. Porém, em contrapartida, ele tornou também a língua portuguesa obrigatória, condenou os ritos e crenças indígenas e perseguiu a bigamia (LISBOA, 1924).

Dessa forma, as medidas portuguesas em relação ao índio não podem ser entendidas senão como forma de garantir a ocupação do território, uma vez que eles não tiveram sua identidade exatamente legitimada ou respeitada. Como afirma Vainfas (2000, p. 51), eles eram "concebidos como mão-de-obra e súditos de segunda classe", cuja reforma objetivava transformar num exército de trabalhadores agrícolas em face da crise da escravidão negra.

Mesmo abolido em 1798, conservou-se traços do espírito desse Diretório na legislação do império, de modo que, em meados do Século XIX, a política imperial contrastava com o lugar que se começava a atribuir ao índio na sociedade, que passava a ser destacado como uma das bases do tripé de formação da cultura nacional; na literatura e nas artes, por exemplo, o indígena era alçado "à categoria de símbolo romântico da nacionalidade originária" (VAINFAS, 2000, p. 53), despontando a literatura indianista, com índios idealizados (e, diga-se, europeizados) como os que protagonizaram os romances $O$ Guarani, Iracema e Ubirajara, de José de Alencar, publicados na segunda metade do século XIX, ou aqueles heróis dos Timbiras, de autoria de Gonçalves Dias, ou ainda os das poesias de Gonçalves de Magalhães.

A despeito das proibições, sabe-se que a escravidão indígena perdurou no interior e nas fronteiras até o final do Século XIX. As mudanças mais significativas vieram apenas a reboque da República, na qual, mesmo que com caráter tutelar, ainda ligado à formação de mão-de-obra agrícola, foi criado em 1910 o SPI Serviço de Proteção ao Índio - que mais tarde (em 1967) originou a Fundação Nacional do Índio - FUNAI (VAINFAS, 2000).

Contudo, a mudança no padrão de territorialidade ocorreria somente na metade do Século XX, com o Projeto Xingú. E foi preciso esperar pela Constituição de 1988 para que, finalmente, triunfassem politicamente "os conceitos ligados à etnicidade e o reconhecimento da alteridade sobre as noções de 'aculturamento' ou 'civilização'”, conforme proferido por Vainfas (2000, p. 55).

Cabe ressaltar que, se o índio é hoje posto no mesmo plano do português ao tratar-se da História do Brasil, ele não gozou da mesma condição ao longo de todo o período de contato, isto é, não teve a mesma liberdade de expressão, criação ou 
realização. Por conseguinte, as contribuições indígenas que chegaram na atualidade são apenas reminiscências de diferentes culturas silenciadas e oprimidas por um longo período, que conseguiram resistir ao domínio português ou foram incorporadas pelos brancos.

Com relação à alimentação, pouco assimilou-se das culturas indígenas, excetuando-se a transformação da mandioca e do milho (DÓRIA, 2009a). Além dos subprodutos do milho e da mandioca (como o tucupi, por exemplo), o aproveitamento da diversidade da flora nativa (engrandecida com espécies trazidas por portugueses durante a colonização), sobretudo das frutas, foi considerado a grande marca da alimentação indígena que chegou até a alimentação brasileira contemporânea.

\subsection{Portugueses}

Foi o tratado de Tordesilhas, datado de 1494, que garantiu aos portugueses a ocupação do "Brasil" quando aqui chegou Pedro Álvares Cabral, em 1500, o que, contudo, não evitou uma série de disputas nos anos que se seguiram (HERMANN, 2000).

No início do Século XVI, mesmo a faixa litorânea ainda era pouco povoada pelos ditos "descobridores" (HERMANN, 2000). É difícil proceder a uma divisão entre viajantes e colonizadores efetivos, mas estima-se que, entre 1500 e 1700, o número de portugueses no império colonial era da ordem de 700 mil indivíduos (entre América, África e Ásia), dos quais apenas 100 mil teriam desembarcado na América (VENÂNCIO, 2000), conforme ilustra a Tabela 2.

A ocupação efetiva e sistemática do território só iniciou-se com o regime de capitanias hereditárias instaurado em 1532 por D. João III e introduzido em 1534, incentivada por fatores internos e externos. Por um lado, Portugal recuava no norte da África e concentrava-se mais na Índia; por outro, precisava responder às ambições de outros europeus que aqui se encontravam, como os franceses, e reagir à resistência nativa (HERMANN, 2000). 
Tabela 2: Estimativa de imigração portuguesa para o Brasil (1500-1991)

\begin{tabular}{|r|r|r|}
\hline Períodos & \multicolumn{1}{|c|}{ Estimativa } & \multicolumn{1}{|c|}{ Média Anual } \\
\hline $1500-1580$ & & 500 \\
$1581-1640$ & 100.000 & \\
$1641-1700$ & & 10.000 \\
\hline $1701-1760$ & 600.000 & 2.666 \\
\hline $1808-1817$ & 24.000 & 668 \\
\hline $1827-1829$ & 2.004 & 125 \\
$1837-1841$ & 629 & 8.054 \\
\hline $1856-1857$ & 16.108 & 15.810 \\
\hline $1881-1900$ & 316.204 & 25.138 \\
\hline $1901-1930$ & 754.147 & 7.434 \\
\hline $1931-1950$ & 148.699 & 23.563 \\
\hline $1951-1960$ & 235.635 & 7.823 \\
\hline $1961-1967$ & 54.767 & 406 \\
\hline $1981-1991$ & 4.605 & \\
\hline
\end{tabular}

Fonte: Adaptado de IBGE (2000, p. 66).

Vale lembrar, conforme mencionado anteriormente, que o modelo de colonização escolhido para o Brasil não foi o de estabelecer colônias de povoamento, segundo o qual famílias receberiam lotes para cultivar com seus próprios braços e recursos, mas o do estabelecimento de capitanias hereditárias, nas quais 12 famílias poderosas tinham direito de explorar mão-de-obra indígena para cultivar a terra. Era o modelo da grande propriedade com regime de trabalho escravo, aos quais se acrescentavam a monocultura e a produção destinada ao mercado internacional (BEOZZO, 1992).

Foi somente em 1549, no ano da fundação de Salvador e da chegada dos jesuítas, que se instituiu o primeiro governo geral, com Tomé de Souza, correspondente a um esboço de organização administrativa mais centralizada. Foi durante o período de dominação espanhola em Portugal (1580-1640), no entanto, que a administração adquiriu feições mais estruturadas. A "união ibérica" diluiu as fronteiras do Tratado de Tordesilhas e deu início à expansão para o interior, com as primeiras expedições dos bandeirantes em São Paulo (HERMANN, 2000), com as quais se iniciou também a difusão do boi pelo Brasil (VEIGA, 1999). 
As incursões e a consequente expansão para os denominados "sertões", até então proibidas pelo governo português (HOLANDA, 2010, p. 100), prolongaram-se durante todo o período de dominação espanhola, mas, em compensação, deixaram o litoral mais vulnerável ao ataque dos inimigos europeus ao projeto imperial espanhol, como ingleses, franceses e holandeses. No entanto, findo o período de dominação espanhola em Portugal, os portugueses conseguiram expulsar os ocupantes europeus da costa, cuja mais longa ocupação foi a holandesa no Nordeste, que perdurou até 1654. Mantiveram, então, a extensão territorial conquistada, com o alargamento das fronteiras ao norte e ao sul, além de prosseguirem com as incursões ao interior (HERMANN, 2000).

Com relação à atração de portugueses para a colonização, a América despertou pouco interesse nos dois primeiros séculos, razão pela qual houve dificuldade de povoamento, sendo mais comum a presença de minorias como cristãos novos e ciganos, que fugiam de perseguições religiosas. Com isso, para que se pudesse povoar o território, houve, inclusive, indícios de imigrações forçadas (degredos) (HERMANN, 2000).

Entretanto, com o recuo português na Ásia e a descoberta do ouro no Brasil, a conjuntura tornou-se mais favorável. Ademais, merece destaque o desenvolvimento de uma vasta rede de abastecimento interno de longa distância que cresceu em virtude de a mineração ter tido por base arraiais e vilas interioranas que, por sua vez, alteraram o perfil da elite colonial, com ascensão dos comerciantes (HERMANN, 2000).

Outro acontecimento notável no período foi a revolução agrícola do Minho, região situada ao norte de Portugal, que, em razão da generalização do cultivo de milho em detrimento do trigo, triplicou sua produção. Tal fato acarretou o aumento da densidade demográfica e da expectativa de vida e, consequentemente, um excedente de mão-de-obra que fez com que um bom contingente de agricultores minhotos rumassem para o Brasil, apesar de continuar predominando entre os portugueses que vieram para o Brasil os de classes mais altas (VENÂNCIO, 2000).

O início do Século XIX, por sua vez, foi marcado pela entrada de muitos membros da elite que vieram a reboque da família real portuguesa, trazendo hábitos da corte portuguesa (VENÂNCIO, 2000), assim como o apreço pela culinária francesa (DÓRIA, 2009a). Hábitos como o uso de talheres, toalhas de mesa (e até a própria mesa), os quais, de acordo com Dória (2009a), foram rapidamente 
incorporados pela elite carioca na tentativa de diferenciar-se dos demais habitantes do país, espalhando-se posteriormente pelo território nacional. Mediante tal fato, é possível afirmar que a chegada da família real foi o marco do refinamento do mesmo modo que a chegada de estrangeiros no encalço da corte fez crescer a demanda por produtos importados.

Com a Independência do Brasil, os portugueses continuaram a aportar no país; porém, a partir de então, passaram a figurar na história nacional não mais como colonizadores, mas como imigrantes, como é discutido no capítulo 3. Assim, ao se analisar as contribuições portuguesas em relação ao que hoje se entende como culinária brasileira, é preciso atentar para o fato de que os portugueses influenciaram tanto como colonizadores quanto como imigrantes.

A despeito das dificuldades destacadas por Couto (2007) e Dória (2009a) para traçar precisamente as influências alimentares exercidas pelos portugueses a partir da virada do Século XVI e a evolução delas, assim como da própria culinária ibérica através dos tempos, não restam, contudo, dúvidas sobre o papel determinante dos portugueses na definição de um modo de comer nacional. Tais dificuldades decorrem, principalmente, do fato de que são raras as fontes escritas daquela época (COUTO, 2007) e que tais referências permitem, sobretudo, "o conhecimento da alimentação das elites e da alimentação conventual, como atesta a farta história da doçaria, em detrimento do comer popular" (DÓRIA, 2009a, p. 24).

O primeiro fato notável é que é possível perceber com clareza a mundialização da economia alimentar que se esboçou na virada do Século XVI, na medida em que as navegações ibéricas colocaram em contato, ainda que indiretamente em alguns casos, Europa, Ásia, África e América, conduzindo a uma vultosa transação de alimentos mediante um amplo comércio de especiarias, açúcar e escravos (GRUZINSKY, 1999).

É, pois, na passagem do referido século que se passou a ter a dimensão do mundo tal qual se conhece hoje (VARGAS, 1998; CARVALHO, 2007). Chaunu (1995) enfatiza esse processo de "desencravamento", que representa o final do isolamento de algumas áreas e o aumento do contato intersocial na maioria das áreas, como a mais significativa das consequências das navegações europeias.

A partir desse movimento de mundialização econômica, ou em seu interior, diversas espécies animais e vegetais deixaram para trás os limites de seus habitats primitivos para adaptarem-se em outros territórios (DÓRIA, 2009a). Foi o que 
aconteceu com a batata e o tomate na Europa (MONTANARI, 2009b), com o coco e a banana no Brasil (CASCUDO, 2004), dentre tantos outros elementos, conforme ilustrado no Quadro 1, reproduzido a seguir, de espécies exóticas aclimatadas no Brasil:

\begin{tabular}{|c|c|c|}
\hline Espécies & Origem & Época \\
\hline Arroz (Oryza sativa) & China & séc. $17 \mathrm{SP}$; séc. $18 \mathrm{MA}$ \\
\hline Abricó do Pará (Mammea americana) & Antilhas & século 18 \\
\hline Banana (Musa spp) & Ásia & \\
\hline Carambola (Averrhoa carambola) & Ásia & século 19 \\
\hline Chuchu (Sechium edule) & América Central & \\
\hline Coco (Cocus nucifera) & Índia & \\
\hline Coentro (Coriandrum sativum) & Europa Meridional & século 17 \\
\hline Couve (Brassica oleracea) & Europa & século 17 \\
\hline Dende (Elaecis guineensis) & África & \\
\hline Figo (Ficus carica) & Oriente Médio & século 16 \\
\hline Fruta do Conde (Aannona squamosa) & Antilhas & \\
\hline Fruta-pão ( Artocarpus incisa) & Malásia & século 19 \\
\hline Gergelim (sesamun indicum) & Asia & século 16 \\
\hline Graviola (Annona muricata) & América Central & \\
\hline Inhame ( Colocasia sculenta) & Asia & \\
\hline Jaca (Artocarpus integrifolia) & India & século 19 \\
\hline Jatobá (Hymenaeae courbaril) & Antilhas & \\
\hline Macadamia (Macadamia integrifoglia) & Australia & século 20 \\
\hline Manga (Mangifera indica) & Asia & século 16 \\
\hline Melancia (Citrullus lantus) & Africa & século 16 \\
\hline Quiabo (Hibiscus esculentus) & Africa & século 16 \\
\hline Soja (Glycine max) & China & século 19 \\
\hline Trigo (Triticum aestivum) & Asia & século 16 \\
\hline
\end{tabular}

\section{Quadro 1 - Espécies exóticas adaptadas no Brasil}

Fonte: Adaptado de Dória (2009a).

Deve-se notar que a introdução e a adaptação de espécies mudam o curso da história, redefinem o percurso da cozinha e até mesmo a identidade culinária de um povo, como defende Montanari (2009b). Esse fato demonstra-se, por exemplo, pela impossibilidade de se desvincular a Pasta ao Pomodoro da cozinha italiana; imaginar a dieta alemã sem a presença de batatas; ou a comida do litoral nordestino 
sem $0 \operatorname{coco}^{7}$. Tais produtos estão tão arraigados na cultura desses lugares que parecem sempre ter feito parte dela.

Nesse sentido, em meados de 1815, Maximiliano de Wied Neuwied (apud MIRANDA, 2007) já narrava de que modo mangueiras, coqueiros e bananeiras tornavam mais agradáveis os passeios por entre os jardins brasileiros e ofereciam admiração aos estrangeiros. Ele cita variedades exóticas, mas que estavam "incorporadas de tal forma à paisagem que pareciam compor, naturalmente, a identidade do Rio de Janeiro" (MIRANDA, 2007, p. 71). O que se pode perceber é que as espécies exógenas somam-se às endêmicas para constituir a biodiversidade que fundamenta a cozinha moderna (DÓRIA, 2009a).

Assim, as espécies advindas de outras partes e introduzidas aqui durante 0 período colonial somam-se como contribuição portuguesa aos hábitos trazidos por eles.

Acredita-se que os mais abastados tenham tentado, de certa maneira, replicar no Brasil hábitos que mantinham em Portugal, trazendo diversos alimentos e receitas que constituíam a dieta portuguesa daquela época, já influenciada por tantos povos.

Faz-se necessário, então, resgatar hábitos portugueses em sua terra natal para que se possa compreender o comer nacional. É igualmente importante ressaltar as adaptações necessárias à realidade brasileira, salientando ainda as diferenças marcantes entre algumas zonas do país.

A fartura seria, segundo Cascudo (2004), uma das marcas da alimentação portuguesa. $\mathrm{Na}$ dieta, o pão e o azeite eram alimentos sempre presentes, sendo heranças da antiguidade (SENAC, 1998). Havia também as fogaças, cozidas sob as cinzas ou rescaldo. Não faltavam aves, carnes, peixes, leite, ovos, frutos, cereais e mel.

Os peixes consumidos eram vários: cação, tubarão, congrio, lampreia, linguado, entre outros. O maior destaque era a sardinha, o mais popular deles, tido como prato nacional. Destacam-se, ainda, o escabeche, a salmoura de vinagre e as especiarias utilizadas até hoje para conservar os alimentos, aplicadas à sardinha e a outros gêneros. O bacalhau, retrato português no Brasil até a atualidade, já era

\footnotetext{
${ }^{7} \mathrm{O}$ tomate e a batata são espécies de origem da América, enquanto a massa foi levada do Oriente para a Europa (MONTANARI, 2009b).
} 
constante na alimentação de expedições, conservado no sal, parcialmente desidratado (CASCUDO, 2004).

$\mathrm{Na}$ alimentação portuguesa, há também vastos registros de azeitonas, alcaparras, dentre tantos elementos que incrementam as receitas. Derivados do leite também compõem a dieta lusitana. A manteiga e os queijos, de diversos tipos, principalmente acompanhando os vinhos (legado romano), são elementos de presença marcante em Portugal, obrigatórios, notáveis. As uvas, além de serem utilizadas para confecção de vinhos, eram consumidas como frutas, ao lado de laranjas, figos, cerejas, ameixas e outras que eram também penduradas para secar, resultando em uvas-passas e frutas secas. As amêndoas e castanhas eram elementos marcantes, presentes em pratos principais e integrantes da doçaria (CASCUDO, 2004).

A doçaria portuguesa, cujos redutos eram os conventos, berço dos doces com ovos (DÓRIA, 2009a), os quais, segundo Cascudo (2004), surgem como uma alternativa de aproveitar as gemas que sobravam dos ovos cujas claras eram usadas como goma para roupa, merece destaque. Bastante atrelada ao açúcar, ela já era centenária quando este apareceu, sendo anteriormente preparada à base de mel de abelhas. Os alimentos doces são, como aponta Freyre (1997, p. 57), herança moura.

Inseparável do domínio árabe, a doçaria portuguesa reflete o período de dominação muçulmana de Portugal e Espanha. Desse modo, os bolos de mel, assim como o alfenim, figuras moldadas em açúcar, e a alféloa, conhecida vulgarmente no Brasil como puxa-puxa, são presenças árabes que chegaram ao pais carregadas pelos portugueses, o que ilustra a complexidade do processo de formação das cozinhas do mundo e suas imbricações.

Há ainda quatro doces que merecem realce absoluto em Portugal: as queijadinhas de amêndoas, o manjar branco, o pão de ló e os fartes. O manjar branco, também conhecido pelo seu nome francês - blancmanger, era preparado desde a Idade Média (LAUDAN, 2000), sendo uma espécie de papa constituída por carne do peito da galinha bem desfiada (ou peixe cozido nos dias de jejum), leite, açúcar e farinha para engrossar, podendo ser guarnecido ainda de amêndoas. No Brasil, trocou-se a galinha pelo coco, enquanto a farinha de arroz é comumente substituída por amido de milho, e a receita perdura até hoje. A queijadinha preparada com amêndoas, ovos, açúcar, água e massa com farinha - também 
sofreu alterações, sendo a sua versão com coco bastante difundida e consumida até nossos tempos. O pão de ló, por sua vez, ganhou diversos recheios, dos quais um dos mais famosos utiliza a goiabada. Os fartes foram os primeiros bolos doces comidos no Brasil. Com seus típicos recheios de creme, abriram caminho para tantas outras variedades que se popularizariam no futuro. "O bolo possuía uma função social indispensável na vida portuguesa. Representava a solidariedade humana" (CASCUDO, 2004, p. 302), noção que parece ter se difundido por aqui, uma vez que as visitas eram comumente recebidas nas fazendas com um café com bolo (COUTO, 2007), hábito que permanece.

Alguns doces mantiveram-se mais próximos de suas receitas originais. Outros levavam mel na sua preparação inicial e depois assimilaram o açúcar. Este ampliaria as possibilidades da doçaria portuguesa, aportando consigo uma nova gama de sabores decorrentes principalmente da mistura com frutas (CASCUDO, 2004).

Assim, no Brasil, os doces marcaram presença sobretudo por meio de compotas e frutas cristalizadas nos engenhos, preparados em grande quantidade. Entretanto, "se a fartura de doces para os senhores brancos era uma característica dos engenhos, o mesmo não se pode dizer da comida de sal" (SILVA, 2010, p. 54).

Com a atenção voltada ao mercado externo, as roças de subsistência ficavam em segundo plano. Resistindo aos gêneros da terra, muitos portugueses mais abastados, entre os quais os senhores de engenho, importavam carnes, cereais e até frutas. No entanto, as dificuldades de transporte e as precárias condições de armazenagem faziam com que muitos produtos desembarcassem no Brasil já deteriorados ou rançosos, o que praticamente inviabilizava a constituição de grandes estoques de produtos adequados ao consumo e acabava restringindo a dieta a gêneros secos (SILVA, 2010).

Os portugueses já utilizavam cebola, alho poró, sal, azeite e muitas especiarias como temperos (CASCUDO, 2004). Segundo Fausto (2000, p. 26), "especiaria se associa também à ideia de produto raro, utilizado em pequenas quantidades". Para ele, seu alto valor se explicaria pelos hábitos alimentares e também pelos limites das técnicas de conservação existentes. Os processos de conservação e de armazenamento deixavam, frequentemente, os alimentos intragáveis, e as especiarias serviam para disfarçar o sabor desagradável (FAUSTO, 2000). 
Em áreas como Amazônia e São Paulo, contudo, não sucedia a mesma resistência aos gêneros da terra. Na Amazônia, seria o extrativismo a principal fonte de alimentação, o que fez com que houvesse uma aproximação à culinária indígena e até mesmo uma dependência do homem branco em relação aos índios, na medida em que estes é que conheciam os rios e sabiam o que coletar da natureza; tal fato não poupou, contudo, o desaparecimento deles na região (SILVA, 2010).

Já em São Paulo, foram as dificuldades de acesso a produtos importados e uma economia com base de subsistência que aproximaram o paladar português. Segundo Silva (2010, p. 74), a cozinha paulista nascia "com hábitos ibéricos associados a práticas e alimentos indígenas, repassados, posteriormente, aos negros escravos". Espalhou-se também na direção de Minas Gerais, acompanhando a subida da serra por parte dos paulistas, tendo chegado, ligeiramente modificada pela introdução de gêneros locais, ao Mato grosso e Goiás. Para a autora, "a sobrevivência dos paulistas dependeu de sua itinerância, flexibilidade e assimilação de costumes indígenas".

No âmbito das carnes, há registros sobre porcos preparados de diversas formas, cabras, cabritos, coelhos, veados, lebres, perus, vacas, galinhas, dentre outros. Eram consumidos, por exemplo, pernas de cabrito e de veado, pastéis de lebre, queixadas ou trincheiras de vaca, galinhas ao molho, frangos e perus assados, chouriços, etc. (CASCUDO, 2004). Mas, ainda que de maneira indireta, parece ter sido o boi a principal influência portuguesa. Trazido por eles e ligado aos senhores como atividade principal, o boi ganhou símbolo de status. Assim, se nas zonas pecuárias do Nordeste, por exemplo, o carneiro, o cabrito, o bode ou a galinha d'angola são os alimentos consumidos pela maioria da população, o boi é o animal desejado, que se espalhou por todo o país (DÓRIA, 2009a).

Corroborando a importância da introdução da carne bovina, Silva (2010, p. 100) afirma: a "inserção do homem branco no território do sertão viria marcar para sempre uma mudança nos hábitos alimentares do país: a criação de gado e sua transformação em carne-seca", que viria a constituir uma das bases do tripé alimentar da alimentação brasileira apontado por ela como sendo: feijão, farinha e carne-seca.

Apesar de terem imposto muitos de seus hábitos alimentares e trazido consigo diversos de seus alimentos corriqueiros, os colonizadores tiveram que adaptar sua dieta ao que a terra nativa tinha a lhes oferecer, sobretudo ao 
embrenharem-se no sertão. Assim, em São Paulo, adotaram por certo período, junto com outros tantos hábitos indígenas, o costume de comer com a mão (já desaparecido na Europa) e em cuias de cuité, de carregar mel e água em cabaças e de manter em casa um jirau para armazenar as sobras de comida (SILVA, 2010). Também em São Paulo, em função da deficiência no abastecimento de gado, a carne seca por vezes apareceria na forma de toucinho (SILVA, 2008).

Para Dória (2009a, p.35-36), o resultado da entrada do homem branco no sertão:

foi uma culinária em que avultam os caldos e cozidos, aos quais se acrescentava o pão ou seu substituto - a mandioca ou pão da terra -, que deu origem aos pirões e vatapás, estes numa clara adaptação das açordas e migas, ou os ensopados e guisados que originaram a culinária dos nossos molhos e moquecas, bem distinta da tradição dos molhos franceses.

Nesse processo, Dória (2009a) destaca ainda o fato de terem incorporado, nos estratos populares, hábitos como o consumo de pequenos animais e vísceras, estendendo ao Brasil a culinária camponesa ibérica.

Pode-se dizer, afinal, que a contribuição portuguesa vai além dos hábitos e ingredientes herdados de sua terra natal, levando-se em conta que o português agiu em favor da ampliação da biodiversidade local, introduzindo no Brasil espécies advindas de diversas porções do globo. Ademais, se impôs como seletor dos ingredientes da terra, como aquele que vai amalgamar hábitos e ingredientes, tanto os locais quanto os procedentes de outras regiões, em virtude de seus próprios hábitos culturais.

\subsection{Africanos}

Nos trezentos anos de tráfico transatlântico de escravos, entre os séculos XVI e XIX, o Brasil foi a região que importou o maior número de pessoas (REIS, 2000), sendo responsável por quase $40 \%$ dos desembarques efetuados na América (atingindo a marca recorde de $60 \%$ em alguns períodos do Século XIX), chegando a uma cifra entre 3,4 e 4 milhões de indivíduos, entre homens, mulheres e crianças (BEOZZO, 1992), conforme ilustra a Tabela 3. 
Tabela 3: Tráfico negreiro com destino ao Brasil e Américas

\begin{tabular}{|l|c|c|c|c|c|}
\hline Área de destino & $\mathbf{1 5 3 2}$ a $\mathbf{1 6 0 0}$ & $\mathbf{1 6 0 1}$ a 1700 & $\mathbf{1 7 0 1}$ a $\mathbf{1 8 1 0}$ & $\mathbf{1 8 1 1}$ a 1870 & TOTAL \\
\hline Américas & 125.000 & 1.391 .300 & 6.051 .700 & 1.898 .400 & 9.466 .400 \\
\hline Brasil & 50.000 & 560.000 & 1.891 .400 & 1.145 .400 & 3.646 .800 \\
Porcentagem Brasil & $40,0 \%$ & $40,3 \%$ & $31,3 \%$ & $60,3 \%$ & $38,5 \%$ \\
\hline Média Anual Brasil & 735 & 5.600 & 17.194 & 27.936 & 11.396 \\
\hline
\end{tabular}

Fonte: Adaptado de Beozzo (1992, p. 59).

Não se sabe ao certo quando chegou o primeiro africano ao território brasileiro, mas talvez a própria expedição de Cabral trouxesse algum consigo. As primeiras levas de escravos, no entanto, devem ter provavelmente destinado-se ao Nordeste do Brasil, em decorrência da exploração de cana-de-açúcar. Eventualmente, os primeiros grupos teriam sido trazidos, inclusive, de ilhas atlânticas de Portugal onde já se cultivava cana em regime de plantation. Assim, nesse primeiro período, os escravos africanos constituíram-se como mão-de-obra especializada, enquanto os indígenas representavam a força de trabalho nos canaviais (REIS, 2000).

A partir da metade do Século XVI, no entanto, eles passaram a substituir as populações indígenas na lavoura açucareira, processo incentivado tanto pelo declínio da população indígena quanto pela alta rentabilidade do tráfico (REIS, 2000; BEOZZO, 1992).

A partir daí, os africanos tornaram-se força de trabalho em praticamente todos os setores da sociedade, no campo e na cidade. Envolveram-se na produção de açúcar, café, algodão, extração de minérios, agricultura para abastecimento interno, criação de gado, manufaturas, trabalho doméstico, transporte, distribuição de alimentos (REIS, 2000; BEOZZO, 1992), havendo até mesmo escravos que eram vendedores ambulantes nas zonas urbanas no Século XVIII (SILVA, 2008).

Os negros que chegaram ao Brasil vieram de diversas regiões da África. Nesse sentido, Cascudo (2004) afirma que "todas as populações adensadas do Senegal ao Gabão, nas regiões do Congo de Angola e pela Contra-Costa, Moçambique, tiveram representantes nos engenhos de açúcar, na mineração e lavouras brasileiras" (CASCUDO, 2004, p. 163). Muito embora tenham unido-se em 
torno de grupos étnicos principais e até mesmo adotado identidades adquiridas no circuito do tráfico (REIS, 2000), tentaram preservar as identidades culturais dos pequenos grupos e as diversidades existentes entre si (SOUZA, 2007).

Tais africanos tinham, possivelmente, padrões alimentares, preferências e simpatias, formas de preparar as carnes, cereais, vinhos, gulodices, farnéis de viagem ou de expedições bélicas, muito distantes dos modelos dos brasileiros e, certamente, com particularidades regionais. Conheciam o gado, a domesticação dos animais e a irrigação, mas estavam, em muitos aspectos culturais, no mesmo nível dos brasileiros e não dos astecas, dos incas e dos maias (CASCUDO, 2004).

Eles dispunham do inhame, da cana-de-açúcar, da bananeira e do azeite de dendê (FREIXA; CHAVES, 2008). Produziam sal e preferiam uma pedra dele a um torrão de açúcar. Nas feiras, vendiam frutos, ostras secas, cereais, arroz e vinho de palma, dentre outros produtos. Já a carne mais usual era a dos animais caçados e não advindos de pastagens. Elefantes, búfalos, gazelas, antílopes, hipopótamos e crocodilos eram dignos de menção e consumo - sempre assados. $O$ boi raramente era morto para ser convertido em alimento. O cão, por sua vez, servia como refeição, enquanto em algumas regiões não se comiam aves (CASCUDO, 2004).

Assim como os índios, os africanos assavam, tostavam e cozinhavam seus alimentos, sem porém saber fritá-los. Os peixes, não tão abundantes, eram defumados para efeito de conservação; das féculas faziam papas; o pirão era indispensável, pois acreditavam que o alimento dissolvido era mais substancial; os inhames eram transformados em farinha e esta, em bolos para acompanhar a carne ou o peixe. As farinhas de diversas qualidades eram feitas, principalmente, de milho (não o milho americano), de arroz e de mandioca. Já os vinhos eram consumidos em pequena quantidade, em virtude das influências proibitivas do Islã (CASCUDO, 2004).

O arroz era item constante; "com ele veio a fórmula do kuz-kuz, ainda uma permanente nas zonas islâmicas da África Setentrional e Atlântica" (CASCUDO, 2004, p. 169). Conhecido dos africanos, assim como dos portugueses, o cuscuz era preparado com sêmola de arroz, trigo ou milheto e mesclado com carnes, crustáceos e legumes. No Brasil, conheceu o milho e foi umedecido com leite de coco e, exceto em São Paulo, trocou crustáceos e legumes por elementos doces (FREIXA; CHAVES, 2008). 
A pimenta também merece destaque; era consumida pura, mastigada com a comida, esmagada nos caldos de carnes e peixes ou transformada em molhos cuja utilização se revestia de técnica apurada e cuidadosa. Havia os de amendoim, palmas, leguminosas, ervas, raízes, entre outros. Usavam-se temperos, cortavam-se cebolas e cozinhavam-se feijões de vários tipos. Não há registros de óleos vegetais ou animais na alimentação. O azeite, como o de dendê, era usado como remédio e item de decoração de corpos. Os africanos também fabricavam manteiga com a qual se untavam, e usavam leite quase sempre azedo ou coalhado (CASCUDO, 2004).

Com relação aos hábitos festivos, Cascudo (2004, p.176) explica:

\begin{abstract}
A média-das-médias na culinária africana do poente é o bolo, massa de inhame, milho, arroz ou farinha de mandioca, molhado no molho, comido com alguma carne, mas constituindo refeição presumível [...] De permeio, pratos saborosos mesmo para o paladar europeu, laboriosamente elaborados durante dois e três dias, esparregados com moluscos, crustáceos, carnes de várias espécies, temperos de ervas aromáticas, cocção a fogo lento e demorado, numa ciência cautelosa denunciando consciência e tempo. Mas não revelam o trivial e comum, o todo-dia, no regime negro. É comida de dia de festa.
\end{abstract}

Apreciadores de doces, seu repertório era deveras exíguo: constava de doce de coco e papas açucaradas de fubá, maisena, milho e coco, que se destinavam às crianças. O negro de Moçambique era o portador da técnica de extrair leite do coco (CASCUDO, 2004; CAVALCANTI, 2007), "[...] para ele mínima e não característica e para nós imensa, de obter o leite de coco e misturá-lo aos alimentos" (CASCUDO, 2004, p. 184).

No entanto, é fundamental atentar para a condição africana de escravos. Não foram eles, e sim os portugueses, que trouxeram muitos dos produtos africanos para o Brasil, no contexto do comércio mundial do colonialismo (CAVALCANTI, 2007; DÓRIA, 2009a); e, provavelmente, selecionaram de acordo com seu interesse comercial, seu paladar pessoal e as possibilidades de uso que atribuíam a cada um deles.

Tampouco os africanos escravos tiveram a liberdade de desenvolver uma culinária própria no Brasil. Como afirma Dória (2009a), ela ficou, num primeiro momento, resumida à necessidade de aplacar a fome. Desse modo, suas principais influências se deram somente no Século XVIII; mais expressivamente no Século XIX, quando a escravidão foi abolida. 
Importante esclarecer, ainda, o clima sob o qual se deu essa abolição no Brasil. Desde o Século XVI, embora em pequeno número, eram concedidas alforrias aos escravos. Assim, para Reis (2000, p.87; p.93), com o aumento das pressões abolicionistas e considerável incidência de filhos mestiços, a partir do Século XVIII "uma notável população livre de cor começou a emergir", despertando preocupação política nas elites locais, razão pela qual a elite nacional do Século XIX "apostou delirantemente na criação de uma sociedade europeia nos trópicos". Instauraram-se políticas públicas de branqueamento demográfico e cultural, com esforços envidados no sentido de promover a imigração europeia, incentivada pelo governo, como é analisado posteriormente, no capítulo 3 (REIS, 2000).

Foi nesse ambiente que se concretizou a abolição da escravidão no Brasil, com "muitos de nossos intelectuais divulgando ideologias europeias raciais, travestidas de ciência, que pontificavam sobre a inferioridade do negro e a degenerescência do mestiço", enquanto outros afirmavam que a mestiçagem, ao "branquear" a população, acabaria por representar, com o passar do tempo, mais uma solução do que um problema (REIS, 2000, p.93).

Dessa maneira, ainda segundo Reis (2000), mesmo depois de abolida a escravidão, foram inestimáveis as dificuldades enfrentadas pelos africanos no Brasil, sobretudo em áreas como São Paulo, em que um expressivo contingente de imigrantes havia se estabelecido e o racismo manifestava-se nos diferentes ambientes. Com relação a este quadro, Fernandes (1978) ressalta que a entrada do negro no mercado de trabalho em São Paulo processou-se lentamente, tendo ocorrido sobretudo a partir de 1920, quando declinaram as imigrações europeias para a cidade, que passou a receber também um maior contingente de migrantes de outras partes do território nacional, assunto analisado no próximo capítulo.

Em São Paulo, apesar do pequeno contingente de negros quando comparado a outras áreas do país, desenvolveram-se fortes movimentos políticos de defesa dos direitos da população afro-brasileira, para lutar pela cidadania recém adquirida, destacando-se nesse sentido o surgimento da imprensa negra paulista, que tem no Menelick, de 1915, sua primeira expressão, seguindo-se pelo 'A Rua' (1916), 'O Alfinete' (1918), 'A Liberdade' (1919), 'A Sentinela' (1920) e 'O Getulino' e o 'Clarim d'Alvorada' (1924) (MOURA, 1989).

Foi no Rio de Janeiro, no entanto, que intelectuais, dentre os quais se destacam Sérgio Buarque de Holanda e Afonso Arinos, aproximaram-se da cultura 
negra em busca de manifestações consideradas por eles "genuinamente" nacionais, funcionando como uma espécie de mediadores entre a cultura erudita e a popular, elevando o samba, por exemplo, a símbolo da identidade nacional (REIS, 2000).

Na mesma linha, obras como Casa Grande \& Senzala, de Gilberto Freyre (1998), refutavam as teorias raciais e enalteciam a mestiçagem racial e cultural, deflagrando o clima nacionalista da época em que foi publicado, em 1933. Mas, como explica Reis (2000), se, por um lado, o Brasil parece ter aprendido a não ter vergonha do lado negro da sua cultura (assim como do indígena), por outro, parece que o esforço em promover e igualar econômica e socialmente os negros e mestiços não acompanhou tais movimentos (FERNANDES, 1978; SOUZA, 2007; DA MATTA, 1996).

\subsection{Culinária portuguesa nos trópicos}

Diante do exposto, alinhando-se a Dória (2009a), é preciso que se esteja atento quando as contribuições de índios, portugueses e africanos "são tomadas como equivalentes, sem reterem a história da opressão que marcou o colonialismo e, portanto, o poder seletivo que o colonizador exerceu sobre os colonizados" (DÓRIA, 2009a, p. 24). E, igualmente, quando pretende-se minimizar ou ocultar as significativas disparidades que perduraram nas mais diversas áreas do país. Não se pode comparar a realidade do litoral à do sertão, nem a das elites à dos demais, sendo importante notar que existe considerável diferença até mesmo em como as coisas vão sendo amalgamadas em cada cenário especifico.

Assim, parece válido afirmar que a culinária brasileira desde 0 estabelecimento dos portugueses até o final do império é, majoritariamente, uma culinária portuguesa que se desenvolvera nos trópicos, que se valeu de ingredientes locais e incorporou técnicas indígenas, sobretudo como forma de sobrevivência; que trouxe ao Brasil produtos africanos e fez deles executores enquanto escravos; em que os estratos sociais mais baixos vão tentar se aproveitar ao máximo daquilo que a terra lhes oferece, enquanto as elites vão buscar se aproximar daquilo que existe além-mar, com o objetivo de se diferenciarem culturalmente dos demais habitantes do país. 
Corroborando tal ideia, Couto (2007) demonstra que aquele que se acredita ser o primeiro receituário brasileiro publicado (em meados de 1840) - O Cozinheiro Imperial - é formado, em grande parte, por receitas extraídas de duas obras portuguesas: O Cozinheiro Imperial, arte de cozinha, de 1758, e Cozinheiro Moderno, de 1785.

No entanto, mais do que isso, a própria tríade brasileira e igualmente paulista apontada por Silva (2010), feijão, farinha e carne seca, aparentemente tão local, parece refletir essa realidade. Isso porque ela corresponde igualmente às exigências do paladar do colonizador e à necessidade de adaptação aos trópicos (o que envolve questões de conservação, armazenamento e transporte).

Em São Paulo, onde o milho era a base da alimentação, a própria farinha de milho seria uma adaptação portuguesa do milho socado consumido pelos indígenas; enquanto o feijão, até então ingerido seco, passou a avultar caldo num reflexo claro ao apreço dos portugueses pelo contraste entre os alimentos secos e os caldos e molhos; a carne seca (ou mais especificamente o toucinho), por sua vez, é uma marca da inserção do homem branco no sertão, como já abordado anteriormente (SILVA, 2010).

Essa perspectiva pressupõe, conforme já exposto, um equilíbrio diferente nas diversas localidades, conforme as características da área, os ciclos econômicos, as relações de trabalho estabelecidas, dentre outros aspectos; entendendo, contudo, a existência de uma relação de poder exercida pelos portugueses.

Ainda, a realidade de deslocamentos frequentes que marcaram a história da humanidade põe em xeque a noção de algo genuíno e eterno, e a transforma numa marcação temporal. Sobre o tema, Pieterse (2007) defende o fato de todos serem imigrantes na medida em que, em algum momento, os seus ancestrais se deslocaram, levando ou trazendo consigo uma outra cultura.

Assinala-se, por fim, que entender a culinária brasileira e especialmente paulistana sob o ponto de vista da construção da sua identidade, ou das suas identidades, e da consolidação de um estereótipo, assim como sobre o estabelecimento dos hábitos alimentares e a constituição da oferta formal da atualidade, pressupõe atentar igualmente para os fluxos que se sobrepõem a partir de então, a serem explorados na sequência. 


\section{FLUXOS E A MESA PAULISTANA}

A história da cidade de São Paulo é marcada por intensos fluxos migratórios: estrangeiros vindos de diversas partes e brasileiros de outros Estados ou do próprio interior de São Paulo, que juntos contribuíram para a formação dessa mesa miscigenada que lhe é característica.

Em adição a esses, uma variedade de outros fluxos tomam forma nos dias atuais - caracterizando a globalização contemporânea - e vão modelar a economia e a sociedade, tendo impacto também no âmbito da alimentação.

Dessa forma, compreender ainda que em linhas gerais esses processos de imigrações, migrações internas e globalização é condição fundamental para que se possa refletir sobre a gastronomia da cidade de São Paulo.

\subsection{Imigração}

São numerosas as contribuições imigrantes trazidas ao Brasil, especialmente a São Paulo, a partir do Século XIX (IBGE, 2000; KLEIN, 2000). Conforme observase no Gráfico 1, o Brasil recebeu, entre as últimas décadas do Século XIX e 1970, cerca de 5 milhões de estrangeiros, dos quais o Estado de São Paulo abrigou mais da metade, em um total de aproximadamente 2,8 milhões de pessoas, sendo $36 \%$ de italianos, $20 \%$ de portugueses, $16 \%$ de espanhóis e $8 \%$ de japoneses (BASSANEZI et al., 2008).

A intensidade desse processo migratório para São Paulo justifica-se porque a ascensão de São Paulo como região dinâmica da economia deu-se justamente no momento da crise do sistema escravista, com consequente necessidade de substituição de mão-de-obra na lavoura cafeeira (GREGORY, 2000; FAUSTO, 2000). Conforme afirmam Bassanezi e seus colegas (2008, p. 19), "o impacto desse contingente de imigrantes se fez sentir desde o início no desenvolvimento econômico, político, social e cultural desse estado e particularmente de sua capital", tendo reflexo na mesa paulistana. 


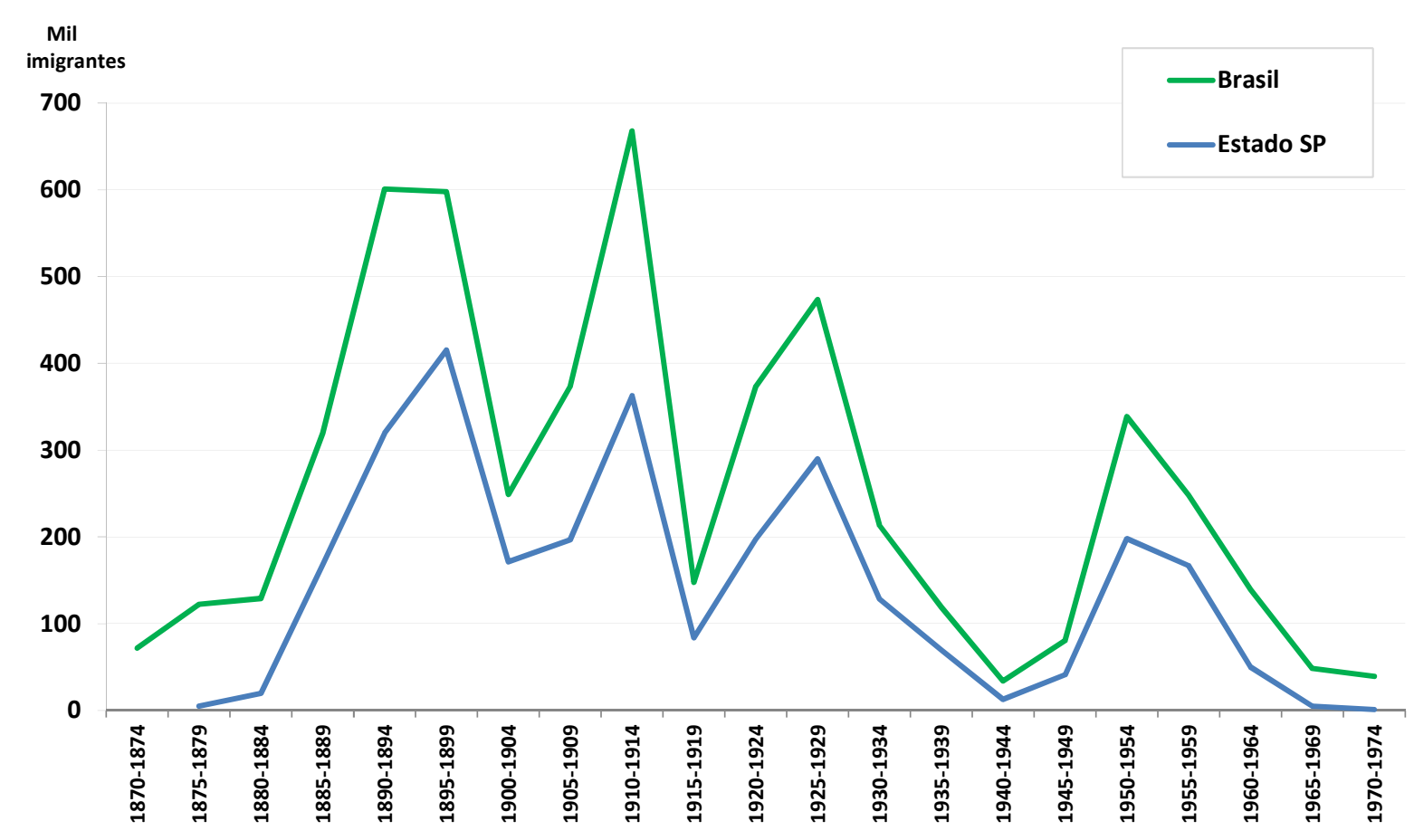

\section{Gráfico 1: Imigração - Brasil e Estado de São Paulo}

Fonte: Elaborado pela autora (MEMORIAL DO IMIGRANTE, 2010; IBGE, 2000, p. 225).

O que se observou foi que, se até 1870, segundo Hogan e Berlinck (1974), o município de São Paulo era uma região estagnada e não passava da $14^{a}$ cidade do Estado, sua posição estratégica entre as demais cidades do Estado e o porto de Santos fez com que ela se constituísse como o ponto adequado de intermediação capitalista, com a produção cafeeira expandindo-se para o oeste paulista, recebendo consideráveis investimentos por parte dos ingleses, sobretudo no setor terciário. Desse modo, segundo esses autores, São Paulo inseriu-se no sistema capitalista e, portanto, internacional, adquirindo novas funções.

Os recrutamentos iniciais de estrangeiros haviam sido feitos pelo governo imperial na época da independência com a intenção de ocupar o território, distribuindo terras devolutas para famílias de policultores, a exemplo do que aconteceu no sul do país nos primeiros anos de colonização (BASSANEZI et al., 2008; GREGORY, 2000; SEYFERTH, 2000).

Os primeiros que vieram foram os alemães, seguidos, a partir de 1870, pelos italianos, constituindo, assim, as duas etnias majoritárias nos Estados de Santa Catarina e Rio Grande do Sul. A distribuição de lotes a imigrantes deu-se, no 
entanto, apenas para um pequeno contingente de famílias nesse primeiro momento de imigração, com concentração no sul (BASSANEZI et al., 2008; SEYFERTH, 2000; GREGORY, 2000).

Em São Paulo, com os grandes latifúndios de café, a imigração aconteceu de outra forma, qual seja como braços para a lavoura cafeeira, de forma que os núcleos de distribuição de pequenas propriedades tiveram papel secundário (BASSANEZI et al., 2008; ALVIM, 2000). Assim, foi a partir de 1880, quando se deu a introdução dos navios a vapor em substituição à vela (KLEIN, 2000) e com a iminente abolição da escravidão negra, que se sucedeu em 1888, que a grande leva imigratória passou a rumar em direção a São Paulo (Tabela 4) (BASSANEZI et al., 2008; MEMORIAL DO IMIGRANTE, 2010; ALVIM, 2000).

Tabela 4: Distribuição percentual da população estrangeira por regiões (1872-1940)

\begin{tabular}{|l|cccc|}
\hline Regiões / Área & $\mathbf{1 8 7 2}$ & $\mathbf{1 9 0 0}$ & $\mathbf{1 9 2 0}$ & $\mathbf{1 9 4 0}$ \\
Norte & 2,2 & 0,6 & 2,7 & 1,4 \\
Nordeste & 13,3 & 5,2 & 2,1 & 1,4 \\
Leste $^{8}$ & 60,6 & 34,6 & 25,3 & 23,1 \\
São Paulo & 7,6 & 41,4 & 52,4 & 57,8 \\
Sul & 15,8 & 17,1 & 15,7 & 14,5 \\
Centro-Oeste & 0,5 & 1,1 & 1,8 & 1,8 \\
\hline
\end{tabular}

Fonte: Adaptado de Beozzo (1992, p. 95).

Por que São Paulo? Porque os fazendeiros do café estavam muito bem representados tanto no governo paulista quanto no governo central e tinham muito interesse em tornar a mão-de-obra abundante, reduzindo, assim, seus custos. Paralelamente, com a prosperidade do negócio do café, esses empresários providenciaram uma significativa infraestrutura que incluía portos, ferrovias, alojamentos de imigrantes, máquinas de benefícios, entre outros. Além disso, desenvolveram mecanismos de financiamento tanto da produção quanto da

\footnotetext{
${ }^{8}$ Região Leste é composta por Rio de Janeiro, Minas Gerais e Espírito Santo (BEOZZO, 1992).
} 
comercialização e da importação de imigrantes pelo Estado, por meio das políticas de subsídios que privilegiavam a imigração em unidades familiares (BASSANEZI et al., 2008).

O procedimento mais convencional era que o desembarque fosse feito em Santos (mesmo que a propaganda feita aos candidatos à imigração fosse o modelo sulista, aplicado aos primeiros imigrantes, de doação de terras para cultivo próprio). De lá, os imigrantes eram levados para a hospedaria dos imigrantes, na cidade de São Paulo, onde eram contratados por agentes de fazendeiros do interior do Estado, para onde seguiam (BASSANEZI et al., 2008; MEMORIAL DO IMIGRANTE, 2010).

A primeira experiência com imigrantes do Estado de São Paulo foi realizada nos anos de 1840 pelo senador Nicolau Vergueiro, em Limeira, que estabeleceu parcerias com eles, mediante as quais teriam remunerações proporcionais ao que fosse obtido de lucro com a venda (BASSANEZI et al., 2008).

O modelo proposto inicialmente por Vergueiro, por causa dos riscos a que se expunha o imigrante, rapidamente evoluiu para o "colonato", pois a abundância de terras fez parecer razoável ao fazendeiro que uma parcela da remuneração fosse não monetária, como as terras para cultivo de subsistência por exemplo (BASSANEZI et al., 2008).

Cabe lembrar que os fazendeiros paulistas já haviam sofrido uma espécie de deficiência crônica de mão-de-obra, uma vez que, quando a economia cafeeira começou a prosperar, tiveram de importar escravos de outras províncias, sobretudo do Nordeste e Minas Gerais. Por isso, foram necessárias estratégias para convencer o trabalhador europeu a vir para o Brasil às vésperas da abolição (BASSANEZI et al., 2008).

Se por um lado a crise italiana, por exemplo, com excedente de população rural favorecia o desejo de os trabalhadores emigrarem, por outro ainda era preciso concorrer com outros países que se mostravam como destinos alternativos, como Estados Unidos, Argentina e Canadá (BASSANEZI et al., 2008; KLEIN, 2000). E, apesar das propagandas que eram feitas além-mar e dos subsídios do governo, o Brasil foi o quarto colocado como destino de emigrantes, sobretudo europeus, nos primeiros anos de independência política, conforme indica a Tabela 5, que reúne dados de 1871 até 1920 referentes à imigração para esses quatro países.

Essa situação explica-se em decorrência do modelo de grande propriedade instaurado desde o período colonial, que se mostrava desfavorável às perspectivas 
de o colono se tornar proprietário (BASSANEZI et al., 2008; BEOZZO, 1992). Acrescenta-se que o Brasil distinguia-se também pelo clima, bastante diverso daquele encontrado nos países temperados, e pelo cultivo aqui ser majoritariamente de uma espécie tropical, o café, com o qual os europeus não estavam familiarizados (PROJETO IMIGRANTES, 2010).

Tabela 5: Imigração registrada de quatro países (1871-1920)

\begin{tabular}{|l|rc|rc|rc|rc|rc|}
\hline & \multicolumn{2}{|c|}{ BRASIL } & \multicolumn{2}{|c|}{ ARGENTINA } & \multicolumn{2}{c|}{ CANADÁ } & \multicolumn{2}{c|}{$\begin{array}{c}\text { ESTADOS } \\
\text { UNIDOS }\end{array}$} & \multicolumn{2}{c|}{ SUBTOTAL } \\
Período & $\times 1000$ & $\% \mathrm{H}$ & $\times 1000$ & $\% \mathrm{H}$ & $\times 1000$ & $\% \mathrm{H}$ & $\times 1000$ & $\% \mathrm{H}$ & $\times 1000$ & $\% \mathrm{H}$ \\
$\mathbf{1 8 7 1 - 1 8 8 0}$ & $\mathbf{1 9 3}$ & 5,1 & 451 & 11,9 & 343 & 9,0 & 2.812 & 74,0 & 3.799 & 100,0 \\
$\mathbf{1 8 8 1 - 1 8 9 0}$ & $\mathbf{5 1 3}$ & 6,6 & 1.090 & 14,1 & 886 & 11,5 & 5.247 & 67,8 & 7.736 & 100,0 \\
$\mathbf{1 8 9 1 - 1 9 0 0}$ & $\mathbf{1 1 4 4}$ & 18,7 & 933 & 15,3 & 339 & 5,6 & 3.688 & 60,4 & 6.104 & 100,0 \\
$\mathbf{1 9 0 1 - 1 9 1 0}$ & $\mathbf{6 8 9}$ & 5,2 & 2.103 & 16,0 & 1.543 & 11,8 & 8.795 & 67,0 & 13.130 & 100,0 \\
$\mathbf{1 9 1 1 - 1 9 2 0}$ & $\mathbf{8 1 8}$ & 8,3 & 1.553 & 15,8 & 1.712 & 17,4 & 5.746 & 58,5 & 9.829 & 100,0 \\
\hline TOTAL & $\mathbf{3 . 3 5 7}$ & 8,3 & 6.130 & 15,1 & 4.823 & 11,9 & 26.278 & 64,7 & 40.588 & 100,0 \\
\hline
\end{tabular}

Nota: Não há para o período dados líquidos de imigração, que considerem apenas os imigrantes que fixaram residência permanente no país.

Fonte: Adaptado de Beozzo (1992, p. 97).

Assim, muitos dos que vieram ao Brasil o fizeram principalmente por não disporem de recursos para dirigirem-se a outro local, visto que o governo brasileiro Ihes pagava a passagem (BASSANEZI et al., 2008; ROCHA, 2007; BEOZZO, 1992; $K L E I N, 2000)$. Existe também o fato de que muitos dos que vieram retornaram para seus países de origem ou embarcaram rumo à Argentina, por exemplo, seja por não terem conseguido adaptar-se, por não terem encontrado nessas terras as oportunidades de sucesso que buscavam ou por terem preferido retornar à terra natal quando esta voltava a oferecer melhores condições de vida, quando já estavam em idade avançada ou, mais raramente, quando já haviam atingido seus objetivos (ROCHA, 2007; HUTTER, 1986; KLEIN, 2000).

Embora não se tenha intenção de discutir neste trabalho os motivos que levaram a essas ondas imigratórias e tampouco de se aprofundar nos tantos efeitos desencadeados por elas, é essencial ter em mente que os fluxos migratórios, em geral, refletem a conjuntura na origem e no destino; manifestam e podem provocar, igualmente, mudanças estruturais em ambas as partes. 
Assim, de maneira geral, segundo Bassanezi e seus colegas (2008), a entrada de imigrantes no Estado de São Paulo, no período entre 1870 e 1970, pode ser entendida por meio de quatro fases longas de maior intensidade, separadas por quatro momentos mais curtos de declínio dessas migrações.

A primeira delas iniciou-se com a transição do trabalho escravo para o livre, no momento de rápida expansão da cafeicultura no oeste paulista e quando se introduziram as políticas de subsídio à imigração. É caracterizada pela entrada maciça de italianos, tendo perdurado até 1902 quando a Itália, por meio do Decreto de Prineti, proibiu as imigrações subsidiadas (ROCHA, 2007). Paralelamente, ocorreu a primeira crise de superprodução da cafeicultura (BASSANEZI et al., 2008).

A segunda fase iniciou-se em decorrência da política de valorização do café, com acordo firmado durante o Convênio de Taubaté, em 1906, que estabeleceu que o governo compraria todo o excedente gerado. Foi nesse período que cresceu a entrada de portugueses e espanhóis e a primeira vinda de japoneses, tendo sido interrompida, sobretudo, pela Primeira Guerra Mundial e, em menor escala, pela gripe espanhola e pela geada que dizimou parte dos cafezais paulistas, agravando a crise, agora decorrente de outros fatores (BASSANEZI et al., 2008).

A terceira fase, por sua vez, teve menor impacto na entrada de imigrantes que as anteriores. Pode ser considerada reflexo da recuperação da lavoura cafeeira e do desenvolvimento de outros setores da economia do país, a exemplo da expansão industrial ocorrida no pós-guerra (OLIVEIRA, 2002; VERSIANI, 1993). Durante esse período, aumentou o volume de portugueses, imigrantes do leste europeu e de japoneses que chegavam a São Paulo, coincidindo seu término com o fim da política de subsídios do governo paulista em 1927, com a crise de superprodução do café que teve seu auge em 1930, com a instituição da política de cotas e com a campanha de nacionalização. No cenário internacional, deflagrava-se a crise de 1929 e vigiam novas políticas emigratórias nos países europeus, culminando com o desencadeamento da Segunda Guerra Mundial (BASSANEZI et al., 2008).

A quarta fase correspondeu, então, ao pós segunda guerra, quando houve 0 afrouxamento das restrições à imigração. $O$ volume de entradas registrado nessa fase, contudo, foi bem menos expressivo do que nas anteriores. A cafeicultura já tinha menor representatividade e com isso as migrações para as lavouras eram diminutas, sendo agora substituídas por levas de operários, técnicos industriais e outros profissionais capazes de ocupar postos intermediários indispensáveis à 
expansão industrial da cidade de São Paulo, a qual já marcara também a terceira fase de imigração (BASSANEZI et al., 2008).

Nesse sentido, é interessante notar ainda que a expansão industrial atraiu os imigrantes europeus que haviam inicialmente instalado-se na zona rural, sendo favorecidos desde o início, no que tange à inserção na estrutura social, pela disseminação da ideologia de valorização da raça branca (SEYFERTH, 2002; KLEIN, 2000), o que interferiu igualmente nos fluxos internos, a serem tratados no próximo item (GREGORY, 2000).

Ao longo de todo esse período e mesmo em épocas mais recentes, foram muitos os povos que desembarcaram na cidade, promovendo a notável diversidade cultural que caracteriza São Paulo atualmente (HECK; BELLUZZO, 1999; HOGAN; BERLINCK, 1974; IBGE, 2000; VEIGA, 1999), merecendo especial destaque aqueles que vieram em maior número, como os italianos, portugueses, espanhóis e japoneses, realçados no Gráfico 2.

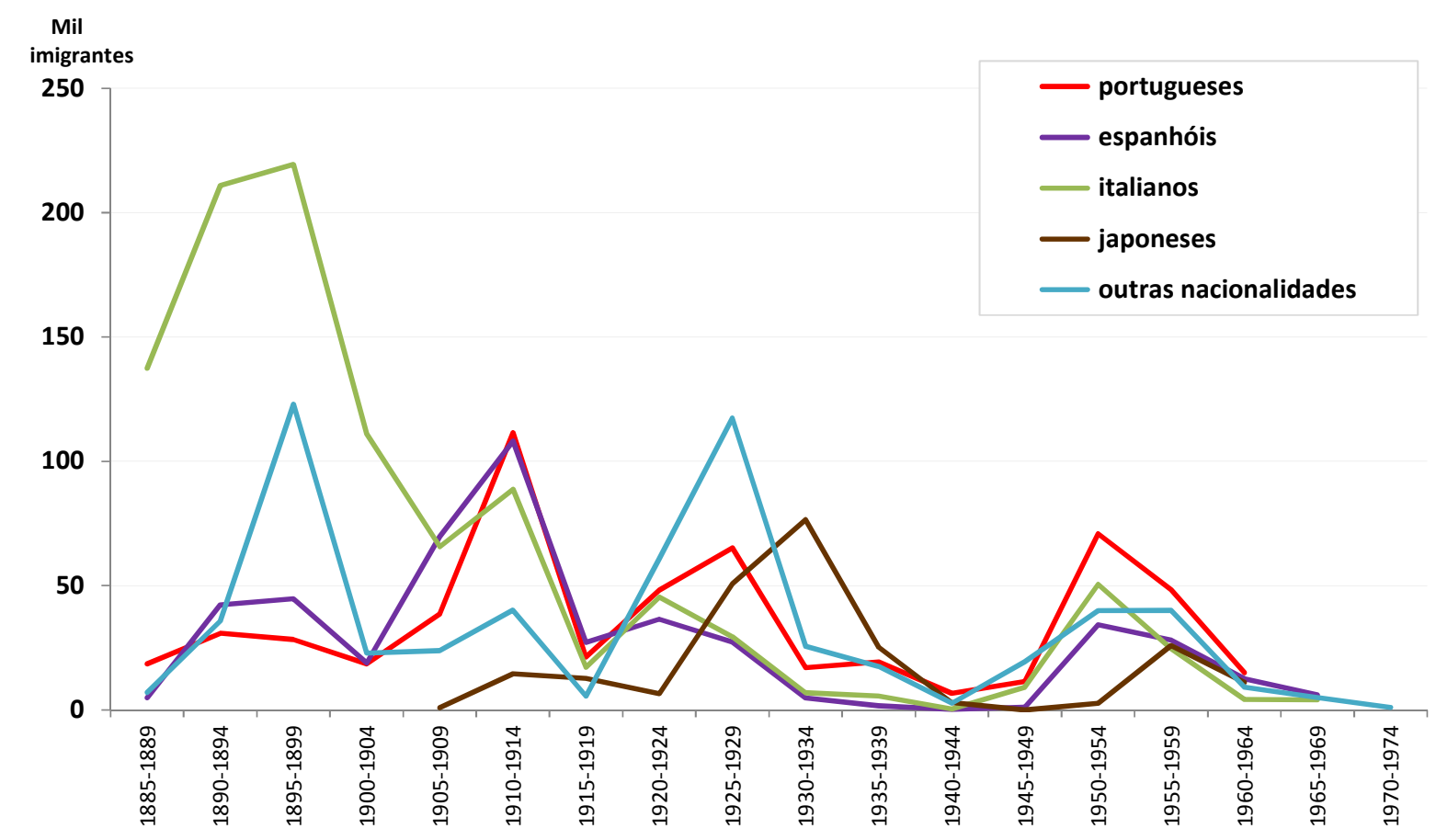

Gráfico 2: Imigração para o Estado de São Paulo por nacionalidade

Fonte: Elaborado pela autora (MEMORIAL DO IMIGRANTE, 2010). 
Os muitos imigrantes que desembarcaram em São Paulo desde meados do Século XIX traziam na bagagem sua cultura, seus hábitos e suas memórias. Nesse sentido, a comida é um elemento de destaque, porque, como afirmam Heck e Belluzzo (1999), o imigrante logo é obrigado a adaptar-se às formas locais de sociabilidade e trabalho, de modo que a culinária estabelece-se como um meio de resistência à completa aculturação. Para elas,

\begin{abstract}
entre as diferentes formas de memória coletiva, uma das mais persistentes é a memória culinária, com sua variedade de sabores, aromas e cores que resistem ao impacto do tempo e até mesmo ao desenraizamento cultural e geográfico. Por isso, a lembrança dos pratos feitos pelos antepassados ocupa um lugar tão importante nos relatos dos imigrantes, obrigados a se adaptarem a novas relações sociais, novos costumes e, sobretudo, novos hábitos alimentares, quando trocam de país.

O sabor de certos alimentos e a singularidade de certos temperos são um testemunho do passado. Eles reafirmam, pela materialidade dos sentidos, que esse passado a cada dia mais distante não se perdeu, que ele sobrevive na maneira especial de assar o pão, no formato gracioso de biscoitos que marcam as lembranças da infância, ou no odor forte de ingredientes que, não sendo encontrados no novo país são preparados em casa, impregnando os quartos e corredores da memória (HECK; BELUZZO, 1999, p. 13).
\end{abstract}

Assim, ilustra-se, com algumas contribuições gastronômicas, a vinda desses imigrantes ao Brasil e especialmente a São Paulo, na tentativa de levantarem-se alguns indícios de como se conformam o multiculturalismo e a miscigenação da mesa que caracteriza esta cidade, transformada em uma espécie de mosaico do mundo, mas com características próprias.

A vinda de portugueses para o Brasil é uma constante desde o início da colonização até a metade do Século $X X$ e não dependeu de medidas subvencionadas pelo governo (ROCHA, 2007), sendo interessante perceber que a chegada em massa desses imigrantes ocorreu justamente a partir do Século XX, quando o país se tornou independente de Portugal, como aponta a Tabela 2 (Estimativa de imigração portuguesa no Brasil), apresentada no capítulo anterior (VENÂNCIO, 2000).

O Século XIX, em virtude do aumento da capacidade produtiva, foi marcado por um significativo aumento populacional das zonas rurais europeias, contingente que, em muitos países, foi absorvido no meio urbano por causa da industrialização, o que, contudo, não aconteceu em Portugal. Paralelamente, houve o princípio do processo de mecanização das atividades agrícolas, gerando maior contingente de 
mão-de-obra ociosa e diminuição dos padrões de vida dos pequenos produtores rurais; produzindo, por conseguinte, novos candidatos à imigração (VENÂNCIO, 2000; LEITE, 2000).

Os portugueses eram incentivados a vir para o Brasil pelas facilidades da língua e pelas afinidades culturais, fruto da colonização, o que fez com que a maioria dos emigrantes de Portugal tenha destinado-se ao Brasil e não a outros países da América, como aconteceu com os emigrantes dos demais países da Europa (LEITE, 2000). Com isso, Venâncio (2000) afirma que o perfil do homem português que se deslocou para o Brasil mudou em relação ao padrão colonial, porquanto houve um aumento do contingente de pessoas pobres, assim como de mulheres e de crianças. Ainda assim, predominavam os homens e, entre eles, emigrar poderia ser considerado uma decisão de carreira, a fim de aproveitarem os momentos de maiores oportunidades na nova terra (LEITE, 2000).

Mais do que quaisquer outros, espalharam-se por várias regiões do país, dedicando-se tanto a atividades rurais quanto a urbanas. Vieram em grande número para São Paulo, mas concentraram-se ainda mais no Rio de Janeiro, onde controlaram boa parte do comércio de gêneros alimentícios (FAUSTO apud PROJETO IMIGRANTES, 2010).

Os portugueses já vinham colaborando para a constituição gastronômica do Brasil desde os idos de 1500 e continuaram a fazê-lo com a imigração. No entanto, vários dos seus alimentos regulares já eram disponibilizados no Brasil e muitos dos seus hábitos já estavam incorporados, não havendo, assim, tantas remarcas a fazer. Contudo, salienta-se a popularização de receitas como a da açorda, sopa de pão portuguesa, que recebia destaque na alimentação principalmente das famílias mais pobres, que por essa época haviam chegado em maior número. Os esparregados fortaleceram-se igualmente aqui, mas, diferentemente das receitas da terra natal, usavam couve mineira e fubá, uma vez que itens como o espinafre, por exemplo, só se popularizaram com os japoneses (BOURNE, 1973; HECK; BELLUZZO, 1999).

Os espanhóis vieram para o Brasil desde as origens da colonização (GUIMARÃES; VAINFAS, 2000), mas, quando se consideram os fluxos imigratórios posteriores à independência, pode-se dizer que a vinda deles foi impulsionada, mormente, pelos subsídios ofertados e pela ampla propaganda realizada no país (MARTÍNEZ, 2000). 
Os espanhóis que para cá vieram no Século $\mathrm{XX}$ eram principalmente galícios e camponeses da Andaluzia, que chegaram majoritariamente em unidades familiares, normalmente numerosas, enquanto no período colonial a predominância era de castelhanos (MARTíNEZ, 2000; GUIMARÃES; VAINFAS, 2000; ROCHA, 2007).

Concentraram-se no Estado de São Paulo, onde os andaluzes correspondiam a $60 \%$ deles e os galegos a $20 \%$. Não obstante muitos tenham se fixado no campo, sua presença no meio urbano foi ainda mais marcante, tendo dirigido-se principalmente para os grandes centros (GUIMARÃES; VAINFAS, 2000; MARTÍNEZ, 2000). Nesse sentido, Martínez (2000) chama atenção para o fato de os galegos, em grande parte, não terem participado de iniciativas de recrutamento, tendo vindo por conta própria para se estabelecer em São Paulo (MARTíNEZ, 2000). Nas zonas rurais, foram para as fazendas de café, enquanto nas cidades vincularam-se inicialmente ao comércio de metais usados (ferro velho), aos trabalhos manuais (como cristaleria artística e serraria) e ao ramo de alimentação, tendo trabalhado também, em grande número, na construção civil e nas estradas de ferro (ROCHA, 2007; MEDEIROS, 2005).

As contribuições dos espanhóis à gastronomia brasileira em muito se aproximam das dos portugueses, sendo possível conceber uma cozinha ibérica no Brasil. Entretanto, alguns pratos caracterizam claramente o povo espanhol. É o caso da paella, da qual muitas versões difundiram-se no país, como é o caso da receita conhecida como valenciana, preparada com arroz, frutos do mar e carnes. $O$ puchero, cozido de legumes, carnes, sobretudo defumadas, e grão de bico, da mesma forma conquistou muitos lares. Quanto aos doces, destaca-se o o turrón, ou torrone, que aqui ganhou a companhia do amendoim, fruto nativo (BOURNE, 1974; HECK; BELUZZO, 1999).

Os alemães foram os primeiros a chegarem ao Brasil em grande número, havendo constância da imigração desse povo desde a abertura dos portos às nações amigas, em 1808, e especialmente depois da independência. Seyferth (2000) destaca inclusive a presença de indivíduos de ascendência germânica junto ao governo imperial, tendo alguns alemães atuado no comércio de importação e exportação no Rio de Janeiro nessa época. Sua influência no governo talvez possa justificar, ainda, a escolha deles para a ocupação territorial do sul do país, onde instituiu-se o regime de pequenas propriedades com a formação de colônias alemãs. 
Durante boa parte do Século XIX, os imigrantes alemães eram de procedência predominantemente rural, agrícola (GREGORY, 2000; ROCHA, 2007). A partir de 1880, porém, passaram a ter procedência majoritariamente urbana (ALENCASTRO; RENAUX, 1997).

Acredita-se ter sido em 1827 que o primeiro grupo de alemães com destino a São Paulo desembarcou no porto de Santos, tendo o fluxo prosseguido a partir de então (SOLIZ, 2004a). Durante a década de 1830, muitos seguiram diretamente para a primeira siderúrgica nacional, em Sorocaba, enquanto na década de 1840 começaram a ser recrutados para os cafezais do interior de São Paulo; em ambos os casos, por causa das más condições de trabalho, muitos preferiram as cidades e migraram para São Paulo (WEICHERT, 2009). Foi justamente por enfrentarem precárias condições que a imigração alemã foi parcialmente interrompida no final da década de 1850 (SOLIZ, 2004a).

Entretanto, uma nova onda migratória ocorreu a partir de 1880, com a Alemanha já unificada, e teve seu auge com o final da Primeira Guerra Mundial, momento em que se concentraram na cidade de São Paulo, formando o maior núcleo urbano de alemães no país, onde procuravam exercer suas profissões (WEICHERT, 2009). Vale salientar, no entanto, a significativa hostilidade imposta aos grupos alemães em todo o país durante a Primeira Guerra Mundial e as proibições que lhes foram impostas, a exemplo daquelas que baniram as publicações em língua alemã (SEYFERTH, 2000).

As imigrações alemãs para a cidade de São Paulo perduraram depois da primeira guerra, mas declinaram consideravelmente após a Segunda Guerra Mundial, quando passaram a consistir, sobretudo, em executivos e profissionais especializados (SOLIZ, 2004a) que vinham ocupar cargos de destaque em subsidiárias alemãs, naquele que seria o maior polo da indústria alemã fora da Alemanha (SOLIZ, 2004b).

No que se refere às influências gastronômicas, a maior difusão de hábitos se deu no sul do país. Porém, pode-se dizer que, acima de tudo, o alemão reforçou o consumo de alguns alimentos trazidos pelos portugueses no Século XIX, como as carnes salgadas e defumadas e as cervejas (CASCUDO, 2004), assim como o das batatas, que haviam sido levadas da América para a Europa e cujo consumo difundiu-se fortemente na Alemanha, onde passou a constituir uma das bases da alimentação. 
Todavia, as comidas alemãs mais típicas, como as saladas de batata e de beterraba, o toucinho de vitela e de carneiro, as linguiças de fígado e de sangue, os arenques defumados ou em escabeche, o mocotó e o queijo de porco, o chucrute e o pão negro, não se espalharam. Os rollmops (rolinhos de arenque) foram aqui substituídos por rolinhos de sardinha, devendo-se destacar que a força ambiental do novo território influiu fortemente em seus hábitos (CASCUDO, 2004).

Deve-se salientar, contudo, a importância dos alemães (e de outros povos do norte e do leste europeus, por vezes aqui denominados de alemães) nos primórdios da restauração paulistana (BARBUY, 2006).

Os italianos começaram a vir para o Brasil em 1870 e dirigiram-se, em sua maioria, para o sul do país e para São Paulo (ALVIM, 2000; TRENTO, 1988). Correspondendo a $42 \%$ do total de imigrantes no Brasil, de acordo com Alvim (2000), entre 1880 e 1904 chegaram a representar, segundo Trento (1988), 57,4\% dos imigrantes que adentraram o país.

Até a virada do Século XIX predominavam os italianos do norte, especialmente do Veneto, que vieram em núcleos familiares (TRENTO,1988; GOMES, 2000; ROCHA, 2007; ALVIM, 2000). Tratava-se de famílias de origem agrícola empobrecidas, para quem a possibilidade de acesso à terra era um fator decisivo, visto que na maioria eram já pequenos produtores, arrendatários ou meeiros (FAUSTO apud PROJETO IMIGRANTES, 2010) e que, provavelmente em virtude das dificuldades de acesso à terra, foram rapidamente sendo substituídos por italianos meridionais (GOMES, 2000).

Os italianos imigraram também para as cidades, diretamente ou depois de um período de estada nas fazendas (ROCHA, 2007; GOMES, 2000). De acordo com Gomes (2000), São Paulo chegou, no início do Século XX, a ser identificada como uma cidade italiana, haja vista haver para cada brasileiro dois italianos. Eles chegaram a representar $90 \%$ dos 50 mil trabalhadores empregados em fábricas na cidade, ou seja, constituíam a grande massa do operariado da indústria paulista nascente (ALVIM, 2000; GOMES, 2000).

Pode-se assegurar que eles influenciaram fortemente os hábitos alimentares nos locais onde se fixaram. Trouxeram para a culinária brasileira as massas de farinha de trigo, com molhos espessos e condimentados. Suas receitas resistiam às seduções da pimenta e teimavam no uso do azeite doce e da banha de porco, em detrimento do dendê e do leite de coco (CASCUDO, 2004). 
Foram os italianos que levaram para a mesa brasileira inúmeras massas, como o espaguete, a lasanha, o nhoque, o ravióli, o capeletti, o vermicelli, o fuzilli, e que instituíram a macarronada dominical. Apresentaram a polenta e o risoto, ensinaram a ralar o queijo e infiltraram a pizza no paladar nacional. Trouxeram também uma série de receitas com carnes de coelho, de cabrito, ossobuco e peixe, mas a elaboração do preparo e o custo das matérias-primas restringiram-nas, ao contrário do que houve com a base nutritiva de cereais no caso das massas (CASCUDO, 2004; HECK; BELLUZZO, 1999).

A respeito da comida italiana no Brasil dos séculos $\mathrm{XIX}$ e $\mathrm{XX}$, é interessante notar que pratos como a polenta adquiriram novo status à mesa: representativos da privação dos períodos de guerra passaram a ser servidos aqui como iguaria pela comunidade italiana que integrava a classe industrial paulistana (HECK; BELLUZZO, 1999). Outro fato interessante é que a imigração em massa ocorreu pouco depois da unificação da Itália, que se deu em 1871, de modo que, em certa medida, a identidade nacional desses imigrantes forjou-se no Brasil (FAUSTO apud PROJETO IMIGRANTES, 2010). Assim, muitos desses italianos vindos de diversas partes (majoritariamente do Vêneto, Campânia, Calábria, Lombardia, entre outros), entenderam no Brasil o que era ser italiano ou que eram italianos recriando as diferentes "Itálias" e consolidando uma Itália única no Brasil (GOMES, 2000; ALVIM, 2000). Nesse sentido, o alimento, mesmo com suas particularidades regionais, parece ter desempenhado um papel essencial. Foi no Brasil que, de acordo com Romio (2000), a almôndega uniu-se ao espaguete, por exemplo; advindos de regiões distintas na Itália deram, no Brasil, origem a um "clássico Italiano", mas igualmente brasileiro.

A chamada imigração Árabe no Brasil, por sua vez, é predominantemente de Sírios e Libaneses (MOTT, 2000; TRUZZI, 2000), apesar de congregar também armênios, egípcios, turcos, palestinos, iraquianos e outros dos 21 povos que integram o mundo árabe (MÓL DE ARAUJO, 2010). Com o domínio do império otomano, de fé islâmica, e as perseguições aos cristãos, o contingente que imigrou para o Brasil foi sobretudo composto por eles. A confusão classificadora, por sua vez, se dá em especial na primeira fase de imigração, visto que até 1982, por causa da dominação do Império Otomano, eles tinham passaporte turco (MOTT, 2000; TRUZZI, 2000). 
Essa imigração para o Brasil deve ser entendida como migração espontânea, porque, num primeiro momento, os governos sequer eram soberanos e, consequentemente, não podiam participar de qualquer acordo (MÓL DE ARAUJO, 2010). Da mesma forma, cumpre acrescentar que não foram os estratos sociais mais desprivilegiados que imigraram para cá, e que, de início, de acordo com Rocha (2007), o fizeram com a determinação de voltar para a terra de origem, depois de acumularem recursos ou quando atingido o sonho de liberdade. Contudo, com o passar dos anos, por causa da boa adaptação e do sucesso obtido por muitos deles, principalmente a partir de 1929, a imigração deixou de ser provisória para ser permanente (ROCHA, 2007; ALVIM, 2000).

Bastante vinculados às atividades comerciais no Brasil (apesar de, segundo Alvim (2000), os sírios e libaneses não terem em suas terras de origem a mesma dedicação pronunciada ao comércio que gregos, armênios e judeus), eles concentraram-se nas cidades. Tendo deslocado-se majoritariamente para São Paulo, dirigiram-se também, em menor escala, para a região central do Brasil, integrando-se ao ciclo dos minérios (MÓL DE ARAUJO, 2010), e para o norte do país, região caracterizada por baixo fluxo imigratório, onde tiveram um papel relevante no comércio da borracha (FAUSTO apud PROJETO IMIGRANTES, 2010).

Em São Paulo, muitos começaram como mascates, percorrendo as ruas dos centros urbanos com suas mercadorias e levando-as inclusive até as fazendas e pequenas cidades do interior, mas logo foram tornando-se vendeiros, pequenos comerciantes e, ainda, atacadistas, bastante vinculados ao comércio de tecidos e armarinhos", estabelecendo-se na região da 25 de março. Além disso, tendo como partida o trabalho em pequenas indústrias, participaram ativamente do processo de industrialização do país, com a paulatina substituição das importações nas primeiras décadas do Século XX. Além disso, assumiram posições políticas importantes e destacaram-se como profissionais liberais (ALVIM, 2000; FAUSTO apud PROJETO IMIGRANTES, 2010).

Apesar das diferenças étnicas existentes e da estratificação entre Sírios e Libaneses que, por vezes, se fizeram sentir no desenvolvimento de entidades e associações, comumente eles eram vistos como um grupo uniforme pela sociedade local (ALVIM, 2000; MOTT, 2000). Assim, com relação às suas contribuições gastronômicas, raramente as diversas influências árabes são distinguidas por aqui. Os libaneses, assim como os sírios e os armênios, trouxeram uma culinária rica em 
trigo. Destacam-se pelo tahine, base para o homus (pasta de grão de bico) e para a babaganuche (pasta de berinjelas). Como pratos marcantes, há os preparados à base de lentilhas, o quibe em suas inúmeras variações - cru, assado, frito, com molho - além das esfirras e das abobrinhas recheadas. Como temperos, muita cebola, pimenta síria e snúbar ${ }^{9}$ (KUCZYNSKI, 1995). Características também são as amêndoas confeitadas e o cuscuz marroquino, representante também do Marrocos, da Argéria e da Tunísia (HECK; BELLUZZO, 1999).

A culinária síria que chegou de fato ao Brasil aproxima-se bastante da libanesa. Para os sírios, o quibe é trivial, assim como a kafta, carne moída temperada envolta no espeto. É famosa a combinação de lentilha com arroz chamada por eles de mdárdara, pelos egípcios de megadarra e consumida com iogurte pelos judeus. No horizonte das frutas estão as tâmaras, os damascos e as ameixas (HECK; BELLUZZO, 1999).

Os armênios seguiam a mesma linha, consumindo "charutos" de folha de uva, quibe cru, berinjela e abobrinha. Preparavam o khavitz, ou meghle em árabe, doce feito com água, amido de milho, açúcar, manteiga e nozes, que, segundo as tradições, "aumenta o leite materno e proporciona energia para cuidar do recémnascido" (HECK; BELLUZZO, 1999, p. 318).

Os egípcios também guardavam hábitos alimentares muito próximos. Consumiam tâmaras frescas recheadas com amêndoas, damascos e uma série de outras frutas secas. Preparavam cordeiros e favas verdes, usavam cebolas roxas, alho, vinagre, coentro, limão, sal e muito azeite (LIBRARIE LAROUSSE, 1984).

Todos esses sabores foram conquistando os paladares paulistanos e transbordando os limites dos restaurantes típicos para popularizarem-se, na forma de quibe, esfirras e outras iguarias até mesmo em restaurantes de comida rápida.

Os japoneses, por sua vez, começaram a vir tardiamente para o Brasil quando comparados aos europeus, tendo começado a ingressar no país apenas a partir de 1908 (KODAMA, 2000; SAKURAI, 2000; ROCHA, 2007). Apesar de sua imigração também ter sido subsidiada pelo governo paulista, Kodama (2000) e Alvim (2000) destacam o fato de terem sido inicialmente preteridos em detrimento dos imigrantes europeus por causa das amplas distinções (tanto física quanto nos

${ }^{9}$ Snubar: palavra árabe para sementes ovais, muito saborosas, extraídas do pinheiro-manso (Pinus pinea) de um pinheiro. Muito empregadas em receitas doces e salgadas das cozinhas italiana e síriolibanesa. No Brasil também são conhecidas por pinoli. 
costumes e na língua) existentes em relação a eles em uma época de efervescência das teorias raciais. Contudo, pelo fato de a imigração japonesa ter sido incentivada também pelo governo daquele país desde a restauração Meiji, em 1868, e tutelada pelo próprio (SAKURAI, 2000), os japoneses acabaram por constituírem-se como a principal alternativa de mão-de-obra diante das dificuldades impostas pelos governos europeus. Assim, essa imigração tornou-se ainda mais relevante após a década de 1930, quando a de italianos e espanhóis decresceu consideravelmente (KODAMA, 2000; FAUSTO apud PROJETO IMIGRANTES, 2010; ROCHA, 2007; SAKURAI, 2000). Além disso, uma ligação mais próxima com o Japão poderia representar ainda a abertura dos mercados asiáticos para o café (SAKURAI, 2000).

Concentraram-se basicamente no Estado de São Paulo, que chegou a representar 92\% do total de japoneses ingressados no Brasil (KODAMA, 2000). Inicialmente foram direcionados para a cafeicultura e, a partir de 1924, quando os subsídios brasileiros foram substituídos pelos japoneses, passaram a vir em grande número para trabalhar nas terras adquiridas pelas companhias japonesas de emigração, como a KKKK (Companhia Ultramarina de Empreendimentos, fundada a partir da união da Kagai, da Kogyo, da Kabushiki e da Kaisha) (SAKURAI, 2000).

Entre todos os povos que imigraram para o Brasil, foram os que permaneceram por um período mais longo no campo, muitos deles na condição de produtores rurais de pequeno e médio porte, tendo se destacado pela diversificação dos produtos hortifrutigranjeiros (SAKURAI, 2000; FAUSTO apud PROJETO IMIGRANTES, 2010). Ademais, foram os japoneses que impulsionaram 0 surgimento das primeiras cooperativas agrícolas, como a de Cotia por exemplo (SAITÕ; MAEYAMA, 1973). Nesse sentido, pode-se dizer que o fato de estarem acostumados a uma alimentação riquíssima em legumes e verduras acabou rendendo ao Brasil uma série de novas variedades e métodos agrícolas.

Interessante notar que muitos japoneses vieram ao Brasil assistidos pelas companhias de imigração, com intuito de colonização, de modo que em muitos lugares foi instalada uma infraestrutura de apoio, com bancos e escolas, além da criação de associações (SAKURAI, 2000). Assim, era possível que educassem seus filhos como japoneses, ensinando-lhes a língua e os costumes do Japão, de sorte que muitas tradições e hábitos mantiveram-se, entre eles os alimentares.

Acostumados ao consumo cotidiano de peixe, mantiveram-no aqui, mesclando a ele aves e carnes, introduzindo, inclusive, o consumo de peixe cru, 
inicialmente nas regiões litorâneas, onde era possível encontrá-lo fresco. Preparavam anchovas no sal e, quando não era possível encontrá-las, usavam outros pescados, geralmente a sardinha. Apresentaram ao Brasil o missô, que naquela época era feito em casa e, por emanar forte cheiro durante o preparo, era sentido por todos os vizinhos. Preparavam ainda o queijo de soja, conhecido como tofu, o clássico molho shoyu e as conservas, como a de nabo - que chegaram a ser feitas com mamão na falta deste (SALLUM, 2003).

O arroz, de tamanho menor e redondo, era, no início, difícil de ser encontrado, mas acabou popularizando-se. É ingrediente básico para elaborar os variados tipos de sushi e ainda do mochi (ou moti), símbolo de fartura e que atrai sorte segundo os japoneses.

Com tantas diferenças que dividiam o ocidente do oriente, foram muitos os confrontos e conflitos enfrentados pelo povo japonês no Brasil. No entanto, para Kodama (2000), nenhum foi capaz de resistir às mudanças estabelecidas nas relações com o passar do tempo e às trocas culturais que se davam com a sociedade que, aos poucos, os acolheu (KODAMA, 2000).

Inicialmente restritos ao bairro da Liberdade, os aromas e sabores japoneses foram espalhando-se pela cidade e despertando o interesse dos paulistanos, transformando o antigo reduto japonês em São Paulo em um ponto de encontro de muitas culturas que vão à procura dos mais diversos produtos desse povo.

A imigração russa, apesar de bastante populosa na virada do Século $X X$, decresceu bruscamente ao final da década de 1920. Credita-se isso ao fato de boa parte dos russos que aqui desembarcaram serem na verdade poloneses tentando escapar dos tempos difíceis de dominação. Assim, quando a Polônia voltou a ser um país independente, não só as imigrações russas cessaram, como também muitos retornaram para sua terra natal (DECOL, 2000; ROCHA, 2007).

Assim, falar da imigração russa para o Brasil é em certa medida tratar da imigração polonesa, o que leva a tratar igualmente da imigração de judeus para o país (GRÜN, 2000).

No que tange à alimentação, são diversas as receitas russas com peixes, frangos e carnes, mas o prato que mais se difundiu foi o estrogonofe, que na Rússia tinha o caldo de carne simplesmente engrossado com farinha, enquanto aqui leva creme de leite, aproximando-se, nesse sentido, da maneira como é preparado na França. Os russos, por conta do frio que enfrentavam, carregavam consigo o hábito 
do consumo regular de sopas, as mais diversas. A batata também era alimento marcante, muito consumido, e os repolhos eram, por vezes, recheados com arroz e carne moída, como os "charutinhos" árabes, e preparados no molho (POKHLIOBKIN, 1989; LIBRARIE LARROUSE, 1984).

Os poloneses preparavam conservas de pepino com alhos inteiros, cebola e louro; também preparavam repolhos azedos em salmoura com grãos de pimenta e folha de parreira para fermentar. Os repolhos eram bastante consumidos para acompanhar o pato assado e outras carnes, além de serem utilizados na sopa, como a katusznia, feita à base de músculo. Havia, ainda, o borscht, para eles um suco frio de beterraba e para os russos e ucranianos nome dado a várias sopas quentes do mesmo tubérculo (HECK; BELLUZZO, 1999).

Além desses povos já mencionados, que vieram em grande número para 0 Brasil, uma série de outras contribuições pode ser destacada do ponto de vista gastronômico, entre as quais podem ser mencionadas as francesas como bastante significativas.

Os franceses, que já haviam trazido ao Brasil no encalço da corte portuguesa o banquete e incentivado o consumo de gêneros estrangeiros (RENDERIA apud OLIVEIRA, 2010), contribuíram com mais queijos e vinhos, além de diversas carnes, muitas ervas, suas quiches, souflés, dentre muitos outros quitutes, os quais incluem técnicas da culinária clássica que chegaram a São Paulo pela mão dos "chefs" (SALLUM, 2003). Apesar de não terem vindo em número avultado, sua associação com a gastronomia é inestimável. Desde o império foi-se-lhes associada a noção de cozinha requintada, berço da cozinha clássica europeia (DÓRIA, 2009a), tendo a França ofertado cozinheiros ao Brasil desde o início dos restaurantes em São Paulo (SILVA, 2008; BARBUY, 2006).

Os húngaros, por sua vez, sentiam falta do foie gras inteiro, mas tentavam adaptar suas receitas e continuavam a utilizar o repolho, principalmente curtido, e nozes em profusão (HECK; BELLUZZO, 1999).

Com os gregos vieram o queijo feta, o tradicional moussaka - preparado com berinjela, carne moída e molho branco -, a fassoulada - sopa de feijão branco, cenoura, salsão, tomate, cebola - e mais azeite (SALLUM, 2003).

Os iugoslavos continuaram a preparar aqui os hamine, ovos cozidos com casca de cebola por longas horas, que adquiriam coloração amarronzada e que, entre os judeus, simbolizam a vida. Consumiam também massas folhadas com 
diversos recheios e o djuverch iugoslavo, que é uma refeição completa, com berinjela, pimentão, abobrinha, cebola, arroz, molho de tomate e bistecas de porco defumadas. Há ainda os diversos pratos com repolho, como o podvarak, preparado com pato, e o sarma, trouxinha com carne moída (HECK; BELLUZZO, 1999).

Os austríacos trouxeram o goulash - receita austro-húngara cujos ingredientes são carne, páprica picante, kümmel e batatas - e a spatzle - massa feita com ovos, farinha, leite e sal, que, depois de cortada, é cozida e servida com manteiga - como acompanhamento de diversos pratos. O maior destaque dos austríacos, porém, está na doçaria, representada pelas tortas de nozes, de amêndoas, de ricota, e pela sachertorte, torta de chocolate com damasco que se transformou em símbolo do país (LIBRARIE LAROUSSE, 1984).

Os romenos, da sua parte, estavam acostumados a fazer churrascos em bifes, sempre precedidos por uma mesa de frios. Além disso, consumiam os mititeique são rolinhos de carne parecidos com a kafta -, codorna e faisão. Cozinhavam o peixe, sobretudo as trutas, com uma pitada de açúcar, para evitar o ressecamento da carne. Como temperos utilizavam sal, pimenta e muito dill. Preparavam também uma espécie de polenta, igual à italiana, chamada de mamaliga. O milho caracterizava, desde quando imigrou para a Europa no Século XVI, a base da alimentação camponesa da Romênia, assim como da Itália (HECK; BELLUZZO, 1999).

Embora tenham sido citados aqui muitos dos povos que utilizavam receitas judaicas, outros comentários merecem ser feitos. Os judeus podem ser relacionados, segundo Heck e Belluzo (1999), a dois cheiros típicos, o das cebolas e o das maçãs, uma vez que esses dois elementos eram muito comuns em sua culinária. Como bom exemplo, pode-se mencionar o strudel - doce preparado com maçãs, amêndoas e passas - que no Brasil, ocasionalmente, foi feito com banana, por causa do alto preço da maçã. A batata também era ingrediente muito presente, base da alimentação. Há ainda itens como o mocotó de boi, a torta de queijo, preparada com uma espécie de coalhada mais grossa, o pão-de-ló com suco de laranja e a raiz forte.

Os chineses, por vezes, dividiram alimento com os japoneses que aqui já estavam. Trouxeram consigo o hábito de consumir yakissoba, guardaram como tempero o shoyu e o gengibre e continuaram a comer tofu. No Brasil, rarearam o uso de pepino do mar, exíguo no país, e o consumo da sopa de barbatanas de tubarão, 
iguaria cara. Contudo, não abdicaram de suas panelas ovaladas (wok), nem das cumbucas ou dos hashis para comer.

Além do que foi exposto, cumpre acrescentar alguns fluxos imigratórios mais recentes, entre os quais se destacam os coreanos, cuja imigração oficial começou por volta de 1963 (BERQUÓ, 2001).

Tendo concentrado-se em São Paulo, os coreanos dedicaram-se sobretudo ao ramo das confecções (GOMES, 2005). Eles começaram a difundir seus "churrasquinhos", repletos de acompanhamentos e preparados sobre uma chapa especial. No âmbito dos temperos, a maioria dos condimentos já havia chegado ao Brasil pelas mãos japonesas e chinesas, mas coube a eles difundi-los em outras receitas (FRANCO, 2006).

Após a década de 1980, no entanto, as imigrações de longa distância praticamente cessaram. A partir desse período, ao contrário, o país que até então havia acolhido tantos povos começou a enviar emigrantes a outras partes (REIS; SALES, 1999).

Paralelamente, passou a se registrar um fluxo regional, de menor volume, que incluiu movimentos fronteiriços (BERQUÓ, 2001; KLEIN, 2000). No caso de locais como São Paulo, no entanto, essas migrações corresponderam, sobretudo, à vinda de bolivianos e peruanos, que comumente foram trabalhar com os coreanos nas confecções. Diferentemente dos outros períodos, a imigração ganhou marcas de ilegalidade, com a entrada clandestina desses grupos (BERQUÓ, 2001).

Tal procedimento não impediu, porém, que trouxessem seus hábitos alimentares e espalhassem por aqui o gosto pelas suas pimentas, despertassem a curiosidade por outras variedades de milho e de batata (muitas vendidas na feira da Kantuta $^{10}$ (CENTRO DAS CULTURAS, 2010), ao mesmo tempo em que o ceviche, prato típico da culinária peruana, começou a se popularizar na cidade (GUIA QUATRO RODAS, 2009).

Enfim, cada um dos povos imigrantes que chegava ao Brasil, independentemente do número e do período, trazia consigo seus hábitos alimentares, que foram disseminando-se.

Todavia, nem sempre era possível concretizá-los tal qual se fazia na terra natal. Os ingredientes disponíveis não eram os mesmos, nem os preços, que

\footnotetext{
${ }^{10}$ Reduto de imigrantes bolivianos, a feira da Kantuta, realizada na Praça da Kantuta, no bairro do Pari, reúne, entre outras coisas, comidas típicas, artesanato e danças deste país.
} 
seguiam a lei da oferta local. Desse modo, os produtos locais e também aqueles que aqui já estavam aculturados, na medida em que representavam uma alternativa viável à concretização das receitas, foram conquistando novos consumidores e participando de outras receitas.

Nesse contexto, é interessante destacar que, se o alimento é um importante elemento de identidade cultural e a manutenção de alguns hábitos representa a continuação dos laços com a terra natal, conforme afirmam Heck e Belluzzo, paralelamente é também o alimento uma das principais relações do homem com o meio, segundo Blanche (apud CASTRO, 1937, p. 109).

Assim, ao mesmo tempo em os imigrantes disseminaram seus hábitos e receitas, outros foram sendo acolhidos, misturando-se, num processo caracterizado como incorporação cultural. A cidade de São Paulo seria, então, berço para o surgimento de novas receitas, comumente identificadas, porém, como receitas imigrantes - como o bife à parmegiana (DÓRIA, 2009a) que passou a integrar os hábitos alimentares do paulistano -, seja ele nato ou residente da cidade.

Os dados do Censo Demográfico do IBGE de 2000 (IBGE, 2001), o último disponível até o momento, indicavam que havia 195.641 estrangeiros, de 110 nacionalidades, morando na cidade de São Paulo, representando 1,9\% dos seus habitantes. Quando considerados também aqueles de ascendência estrangeira e os descendentes de estrangeiros, contudo, o número assume expressividade.

Dentre esses estrangeiros, destacam-se, principalmente, aqueles oriundos de: Portugal (63.275); Japão (22.005); Itália (19.786); Espanha (13.782); Bolívia (7.723); Coréia do Sul (7.015); Chile (5.189); Argentina (5.183); China (4.789); Líbano (4.615) e Alemanha (4.527).

Considerando-se a distribuição geográfica dentro dos 96 distritos da cidade, aqueles com maior número de estrangeiros eram: Vila Mariana (6.938); Jardim Paulista (6.202); Saúde (5.897); Jabaquara (5.434); Itaim Bibi (4.684); Santo Amaro (4.562); Santana (4.544) e Liberdade (4.481), todos eles bairros de classes média e alta.

Por outro lado, tendo por referência o percentual de estrangeiros em relação à população de cada distrito, destacam-se Bom Retiro (13,9\%) e Pari (10,3\%). 
É igualmente interessante verificar a concentração desses estrangeiros, por nacionalidade, em determinados distritos, apresentando-se a porcentagem do total do grupo que aí reside (Tabela 6). Merece assinalar:

- Os portugueses estavam distribuídos por toda a cidade, porém ainda com certa concentração na Zona Norte, nos distritos de Vila Maria (4\%) e Santana $(4 \%)$;

- Os japoneses se concentram no eixo Liberdade, Saúde, Jabaquara e Vila Mariana, que congrega $25 \%$ deles distribuídos de maneira equilibrada entre tais distritos.

- Os italianos marcam presença no município em geral, porém, com destaque para o Jardim Paulista (4\%), Vila Mariana (3\%) e Saúde (3\%);

- Os espanhóis apresentam maior concentração na Zona Leste, nos distritos do Tatuapé (3\%) e Água Rasa (3\%);

- O Bom Retiro concentra coreanos (23\% deles ali residiam); gregos (10\%), bolivianos $(9 \%)$ e paraguaios ( $8 \%$;

- O Jardim Paulista se mostra a principal escolha para aqueles oriundos dos: EUA (14\%), França (11\%) e Argentina (8\%);

- Santa Cecília é a primeira localização para israelitas (26\%), romenos (19\%), egípcios (13\%) e libaneses (7\%);

- Santo Amaro é o local preferido pelas colônias suíça (19\%), holandesa (15\%) e alemã (14\%);

Essa pluralidade cultural é encontrada em poucos lugares. Traz consigo impactos nos hábitos alimentares dos estrangeiros que aqui vivem, mas também, e sobretudo, nos hábitos das pessoas que com eles convivem.

Deve-se lembrar que, no que se refere à miscigenação que caracteriza São Paulo e a mesa paulistana, a essas influências decorrentes dos fluxos imigratórios somam-se, ainda, os fluxos migratórios internos, que serão tratados a seguir. 
Tabela 6: Distribuição dos Estrangeiros em São Paulo: Nacionalidade e Distritos (2000)

\begin{tabular}{|c|c|c|c|c|c|c|c|c|c|c|c|c|c|c|c|c|c|c|c|c|c|c|c|c|c|c|c|c|c|c|c|c|c|c|c|c|c|}
\hline \multirow[b]{2}{*}{ Distrito } & \multirow{2}{*}{\multicolumn{2}{|c|}{ 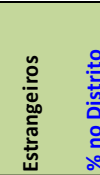 }} & \multirow[b]{2}{*}{ 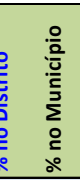 } & \multicolumn{34}{|c|}{ \% Estrangeiros no Município } \\
\hline & & & & 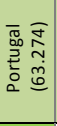 & 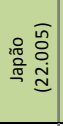 & 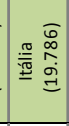 & 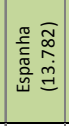 & 离 & 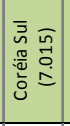 & 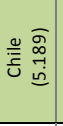 & 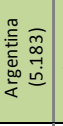 & 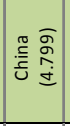 & 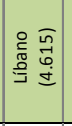 & 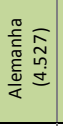 & 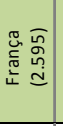 & 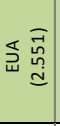 & 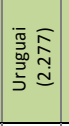 & 商 & 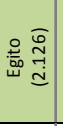 & 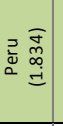 & 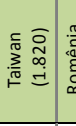 & 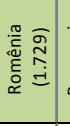 & 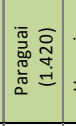 & 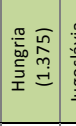 & 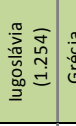 & 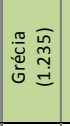 & 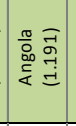 & 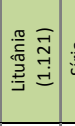 & 愛离 & 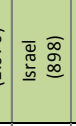 & 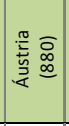 & 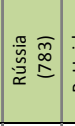 & 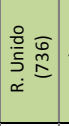 & 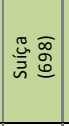 & 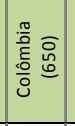 & 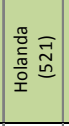 & 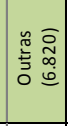 \\
\hline Vila Maria & 3.597 & 3,2 & 1,8 & 3,8 & 0,6 & 1,2 & 1,0 & 4,9 & & 0,2 & 0,2 & 0,3 & 0,7 & 0,8 & & 0,4 & & & & 1,8 & & 1,3 & 1,3 & & 2,4 & & 3,3 & & 3,2 & & 1,3 & & & 1,8 & 1,4 & & \\
\hline Santana & 4.544 & 3,6 & 2,3 & 3,6 & 1,1 & 2,2 & 2,7 & 1,7 & 3,9 & 1,4 & 1,0 & & 2,0 & 0,6 & 2,1 & 0,4 & 1,0 & 0,6 & 1,8 & 2,1 & & & 3,4 & 0,7 & 1,6 & 6,9 & 2,2 & 2,8 & 3,8 & & & 1,4 & 1,5 & & & 1,8 & 1,6 \\
\hline Jabaquara & 5.434 & 2,5 & 2,8 & 3,3 & 6,3 & 2,0 & 3,1 & 2,4 & 1,5 & 2,2 & 1,0 & 0,8 & 1,5 & 0,7 & 1,2 & 1,3 & 3,2 & 0,9 & 1,0 & 0,5 & 1,0 & 2,0 & 1,1 & 4,8 & & 0,8 & 4,0 & & 0,9 & & 3,3 & 1,9 & 1,4 & & 1,4 & 2,1 & 1,8 \\
\hline Tatuapé & 3.430 & 4,3 & 1,8 & 2,6 & 0,7 & 2,7 & 3,0 & 0,9 & 0,8 & 0,8 & 1,2 & 1,8 & 0,9 & 0,6 & 0,4 & & 1,9 & 0,7 & 1,7 & 0,6 & 2,0 & 0,8 & 0,6 & & 0,7 & 0,8 & & 3,3 & & & & & 1,2 & & & 1,4 & 0,9 \\
\hline Água Rasa & 3.207 & 3,7 & 1,6 & 2,6 & 0,7 & 2,2 & 2,9 & & 0,4 & 1,0 & 0,7 & 1,8 & 0,4 & 0,5 & 0,4 & 1,1 & 0,9 & 1,0 & & 0,5 & 1,1 & 2,4 & & & 4,5 & & & 6,8 & & & & & & & & & 0,8 \\
\hline aúde & 5.897 & 5,0 & 3,0 & 2,5 & 6,7 & 3,0 & 2,8 & 1,3 & 0,1 & 2,9 & 0,5 & 4,7 & 4,0 & 1,2 & 0,8 & 2,3 & 2,7 & 2,9 & 1,0 & 2,6 & 17,7 & & 0,8 & 0,8 & 0,6 & & 1,9 & 0,8 & 5,5 & 1,1 & 0,9 & 2,9 & 1,3 & 11,0 & 3,8 & & 3,9 \\
\hline taim Bibi & 4.684 & 5,8 & 2,4 & 2,1 & 0,8 & 2,8 & 2,7 & 0,6 & 0,9 & 2,1 & 6,3 & 5,0 & 1,4 & 4,5 & 3,4 & 5,4 & 2,9 & 2,8 & 4,8 & 2,4 & 2,3 & 2,3 & 1,6 & 1,4 & 2,1 & 2,6 & 0,6 & 0,7 & 1,4 & 3,1 & 6,8 & 3,9 & 5,2 & 6,3 & & 4,9 & 4,5 \\
\hline Perdizes & 4.151 & 4,1 & 2,1 & 2,0 & 1,0 & 2,8 & 1,8 & 1,0 & 2,2 & 1,8 & 4,6 & 1,1 & 1,0 & 0,9 & 3,7 & 5,2 & 4,1 & 2,3 & 4,5 & 2,4 & & 2,6 & 3,6 & 6,9 & 2,3 & 3,6 & 1,9 & 1,7 & 2,0 & 1,7 & 1,9 & 1,6 & 4,7 & 3,1 & 1,7 & 3,6 & 2,4 \\
\hline /ila Guilherme & 2.162 & 4,3 & 1,1 & 1,9 & 0,3 & 0,6 & 0,8 & 5,4 & 0,3 & & 0,3 & & 1,2 & 0,2 & 0,4 & & 1,2 & & 0,5 & 0,4 & & & 0,7 & & & 0,8 & 2,2 & 1,7 & & & & & & & & & 0,6 \\
\hline reguesia d & 2.104 & 1,5 & 1 & 1,5 & 0,9 & 1,1 & 0,9 & 0,3 & & 0,5 & 1,7 & & 0,7 & 1,5 & & 0,4 & & 1,1 & 1,0 & & & 2,4 & 6,9 & 3,3 & 1,4 & & & & & & 1,4 & & & & & 1,9 & 1,2 \\
\hline Vila Sônia & 3.325 & 3,8 & 1,7 & 1,5 & 1,9 & 1,7 & 2,5 & 0,2 & 0,4 & 4,2 & 3,9 & 0,7 & 0,7 & 2,5 & 1,2 & 2,2 & 1,0 & 0,7 & 1,2 & 6,0 & 1,1 & & 2,3 & 1,5 & & 0,7 & 3,1 & 0,9 & 1,2 & 3,9 & 1,2 & 2,7 & 1,5 & & 1,5 & 2,5 & 2,1 \\
\hline $\mathrm{la} \mathrm{Ma}$ & 6.938 & 5,6 & 3,5 & 1,5 & 6,1 & 3,0 & 2,3 & 0,9 & 7,6 & 3,7 & 3,0 & 9,2 & 6,9 & 2,9 & 5,4 & 5,3 & 6,8 & 4,1 & 5,0 & 5,7 & 13,6 & 4,5 & 4,1 & 1,4 & 0,8 & 3, & 3,1 & 1,1 & 11,7 & & & 3,1 & 8,5 & 5,5 & 10,1 & & 4,1 \\
\hline Campo Belo & 4.132 & 6,2 & 2,1 & 1,4 & 1,1 & 2,4 & 2,3 & 0,4 & 0,1 & 1,3 & 3,3 & 4,6 & 0,5 & 8,4 & 7,1 & 3,1 & 4,1 & 1,9 & 2,9 & 2,3 & 7,6 & 0,8 & 0,8 & 4,3 & 2,4 & & 0,7 & 2,9 & 2,1 & 1,7 & 7,3 & 7,4 & & 5,1 & & 8,1 & 3,8 \\
\hline Campo Gra & 2. & 3,0 & 1 & 1,4 & 0,9 & 1,2 & 1,4 & 0,3 & 0,3 & 4,0 & 0,9 & 0,5 & 1,1 & 3,4 & 2,3 & 3,2 & 1,8 & 0,5 & 1,4 & 1,9 & & & 1,4 & 0,9 & & & 2,6 & & & & 2,4 & 1,1 & & 2,7 & 2,2 & 2,4 & 3,9 \\
\hline Cidade Adema & 2.737 & 1,1 & 1,4 & 1,3 & 1,6 & 1,1 & 2,3 & 1,3 & 0,3 & 3,8 & 0,8 & 1,4 & 0,2 & 2,3 & 1,2 & 0,5 & 2,6 & 0,1 & 0,4 & 2,5 & 0,6 & & 2,9 & 2,6 & 3,8 & 1,6 & & & & & 2,3 & 5,7 & 2,6 & 3,0 & & & 1,3 \\
\hline into A & & 7,5 & & 1, & 0,9 & 2,6 & 2,9 & 0,4 & 0,4 & 1,3 & 4,0 & 2,3 & 2,0 & 13,5 & 3,9 & 9,4 & 0,9 & 2, & & & & 1,9 & & 1,5 & 2,4 & & 3,9 & 4,1 & 3,5 & 0,9 & & 9,0 & 8,7 & 18,5 & 3,5 & 14,6 & \\
\hline Moema & 4.239 & 5,9 & 2,2 & 1,3 & 0,8 & 1,8 & 1,1 & 0,3 & 1,6 & 2,9 & 6,0 & 1,9 & 6,8 & 3,1 & 9,9 & 7,9 & 3,5 & 1,4 & 5,8 & 1,0 & 2,6 & 4,9 & 1,1 & 1,7 & 3,6 & 6,8 & 1,0 & & 8,3 & 2,2 & 4,1 & 2,2 & 7,0 & 1,1 & 3,5 & 6,3 & 5,0 \\
\hline $\operatorname{dim}$ & & 7,4 & & 1, & 2,2 & 4,3 & 1,5 & 0, & 1, & 1,0 & 8,0 & 2,2 & 3,7 & 6,4 & 11,4 & 13,5 & 2,4 & 11,5 & 7,3 & & 1,6 & 10,0 & 0,7 & 4,5 & 0,5 & 4, & 9,5 & 0,7 & 9,9 & 16,9 & 4, & 4,3 & 6,5 & 6,9 & 15,2 & 4,0 & 8,2 \\
\hline Butantã & 2.461 & 4,7 & 1,3 & 1,2 & 1,4 & 1,1 & 1,7 & 0,3 & 0,3 & 1,6 & 1,7 & 1,0 & 0,2 & 2,8 & 0,4 & 1,7 & 0,7 & 1,3 & 1,1 & 7,9 & 2,9 & 1,2 & & 0,4 & 0,8 & & 3,1 & 0,8 & & 1,2 & 1,2 & 1,4 & 1,8 & & & 3,3 & 1,0 \\
\hline canduy & & 1,6 & 0 & 1, & 1,1 & 0,8 & 0,6 & & & 0,7 & 0,3 & & 0 & & 0,3 & & 1,7 & 0,4 & 0,3 & 0,9 & 1,0 & & 2,3 & & 1,3 & & 4,3 & 1,8 & & & & 1,2 & & & & & \\
\hline Pinheiros & 3.047 & 4,8 & 1, & 1,1 & 1,2 & 1,3 & 1,3 & 0,4 & 0,5 & 1,1 & 3,5 & 2,4 & 1,1 & 2,4 & 5,0 & 4,3 & 2,2 & 4,4 & 3,4 & 0,6 & 3,1 & 2,2 & & 6,3 & 0,6 & 0,7 & 3,2 & 1,0 & 1,3 & 3,3 & 1,0 & 2,5 & 8,7 & 1,7 & 1,6 & 1,5 & 2,7 \\
\hline Socorro & & 5,0 & 1 & 1,0 & 0,9 & 1,2 & 1,3 & 0,1 & & 0,2 & 1,3 & 0,5 & 0,8 & 3,9 & 1,6 & 0,7 & 0,4 & 0,4 & & 1,2 & 0,4 & 0,5 & 0,8 & 1,3 & 1,4 & 0,7 & & 1,7 & & & 7,5 & & 3,5 & 1,2 & & 3,5 & 0,7 \\
\hline Mooca & 2.436 & 3,8 & 1,2 & 1,0 & 0,6 & 2,8 & 2,5 & 1,3 & 1,5 & & 1,0 & & 2,4 & 0,5 & 1,1 & & 0,4 & 0,5 & 1,3 & & & 0,6 & & & 8,8 & 1,7 & 1,0 & 4,5 & 1,7 & & 1,3 & 1,6 & & & & & 0,6 \\
\hline Lapa & & 3,5 & 1, & 1, & 0,4 & 1,8 & 1,2 & 0,4 & 0,1 & 0,9 & 1,2 & 1,4 & 0,2 & 0,8 & 0,4 & 0,5 & 2,3 & 1,7 & 3,2 & 1,2 & 1,2 & 1 & & 3,0 & 1,8 & 2,4 & 3,1 & 6,4 & 0,9 & & 2,0 & 3,7 & 1,3 & 3,1 & 1,5 & & 0,8 \\
\hline Vila Pruder & 2.480 & 2,4 & 1,3 & 0,9 & 1,0 & 1,9 & 2,1 & 1,2 & & 0,4 & 1,2 & 1,9 & & 0,7 & & 0,8 & 0,4 & 3,4 & & 0,7 & & 5,2 & 0,7 & 0,7 & 4,9 & 0,8 & 0,8 & 20,0 & & & 2,6 & 5,6 & & & & 2,1 & 1,3 \\
\hline Consolac & & 7,5 & 2,1 & 0,8 & 0,3 & 2,6 & 1,2 & 1,9 & 1,7 & 1,5 & 5,6 & 0,7 & 3,8 & 3,6 & 5,3 & 1,5 & 4,9 & 12,1 & 12,3 & 1,2 & 1,2 & 6 & 1,5 & 5,6 & 2,7 & 3,4 & 0,7 & 0,9 & 6,8 & 14,9 & 1,2 & 9,8 & 7,4 & 4,3 & 19,4 & & 2,3 \\
\hline Belém & 1.830 & 4,6 & 0 & 0,8 & 0,1 & 0,9 & 0,6 & 7,0 & 2,1 & 0,4 & 0,2 & 0,9 & 0,7 & & 0,4 & 0,2 & & 0,4 & 0,3 & 1,1 & & 0, & 0,8 & 0,6 & 3,9 & 1,2 & & 5,0 & 1,6 & & & & & & & & \\
\hline Liberda & 4.4 & 7,2 & 2,3 & 0,7 & 5,7 & 0,8 & 0,8 & 1,0 & 15,9 & 0,6 & 0,8 & 7,2 & 2,6 & 0,5 & 2,1 & 0,7 & 1,1 & 1,1 & 1,6 & 0,3 & 21,8 & 0,5 & 2,2 & 1,5 & 0,7 & & 0,8 & 1,0 & & & & & 1,7 & & & 2,5 & 1,6 \\
\hline Vila A & & 2,4 & 0, & 0,5 & 0,3 & 0,7 & 0,7 & & 0,3 & 1,0 & 2,0 & 0,3 & 0,3 & 1, & 1,9 & 7,6 & 6,4 & & 1,5 & 3,7 & 0,6 & & 0,8 & & & 1,2 & 0,9 & & 3,7 & 1,8 & 4,8 & & 3,6 & & 1,8 & 1,9 & 2,5 \\
\hline Repúb & 2. & 5,1 & 1,2 & 0,4 & 0,5 & 1,0 & 0,8 & 2,3 & 1,4 & 1,8 & 1,1 & 11,5 & 0,9 & 1,5 & 1,1 & 2,3 & 3,8 & & 1,0 & 9,2 & & 1,6 & 1,9 & 2,2 & 1,2 & 3,7 & & & 2,2 & 2,0 & & 2,1 & 2,7 & 1,1 & & & 1,0 \\
\hline Bela Vista & 2.789 & 4,4 & 1,4 & 0,4 & 0,8 & 1,7 & 1,9 & 0,9 & 3,2 & 3,5 & 3,4 & 0,8 & 1,7 & 1,3 & 1,7 & 1,7 & 2,7 & 1,2 & 2,4 & 1,4 & 2,6 & 4,0 & 0,6 & 2,5 & & 2,4 & 0,9 & 0,9 & 3,3 & & & 1,2 & 4,4 & 4,4 & 7,4 & 9,3 & \\
\hline Pari & 1.520 & 10,3 & 0,8 & 0,4 & & 0,1 & 0,2 & 3,3 & 9,3 & 0,4 & & & 2,2 & 0,1 & 0,6 & & & & & & & & 0,9 & & 0,9 & 2,5 & & 1,0 & 2,4 & & & & & & & & 12 \\
\hline ita Cecill & 3. & 5,5 & 2,0 & 0,4 & 0,5 & 2,0 & 0,8 & 1,9 & 4,0 & 1,9 & 4,2 & 2,0 & 7,0 & 1,0 & 3,6 & 0,8 & 2,5 & 10,1 & 12,9 & 2,5 & 0,8 & 18,6 & 3,8 & 5,8 & 2,3 & 2,8 & 1,7 & 0,8 & 7,4 & 25,7 & 4,7 & 1,2 & 1,2 & 2,5 & 1,5 & 3,4 & \\
\hline orum & 1.463 & 4,2 & 0,7 & 0,4 & 0,2 & 1,6 & 1,0 & 0,6 & & 0,2 & 1,8 & 1,1 & 0,3 & 1,9 & 8,2 & 1,8 & 0,6 & & & & 2,2 & & & & & 1,2 & 0,9 & & 0,8 & & 1,4 & 1,3 & 1,1 & 1,5 & 2,9 & 2,1 & 0,4 \\
\hline & & 13,9 & 1 & 0 , & 0 & 0, & 0, & 8,9 & 2,8 & 0 & 1,0 & 1,0 & 1,1 & 0,5 & 0,5 & & & 9,9 & 2,1 & & & 2 & 7,7 & 1 & 2,2 & 9 , & 0,7 & 2,6 & 1,6 & 13,8 & & 2,1 & & & & & \\
\hline & 1.062 & 5,3 & 0,5 & 0,1 & 0,7 & 0,2 & 0,2 & 0,4 & & 0,5 & 0,4 & 10,3 & 1,0 & & & & & 0,5 & & 2,1 & 0,9 & 0,6 & 0,6 & & 0,8 & & 3,1 & & & & & & & & & & 0,3 \\
\hline & 9.092 & 4,1 & 0,9 & $y, 1$ & 50,0 & 61,4 & 57,4 & 54,5 & 04,5 & 52,0 & 78,3 & 81,5 & 03,0 & 10,0 & 9,1 & & & 82,1 & (, & 69,1 & $J, 0$ & $\delta<, L$ & נI, & 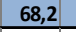 & 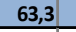 & & , & & 1, & & & & 0,1 & $\infty$ & & 88,5 & \\
\hline
\end{tabular}

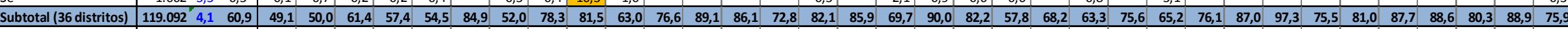

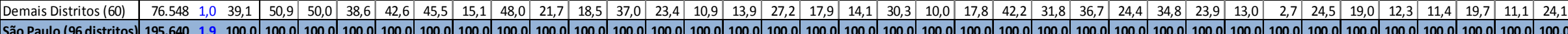

Fonte: Elaborado pela autora (IBGE,2001). 


\subsection{Migrações internas}

As migrações são uma constante na formação histórica do Brasil, (SOUZA, 1980?). Nesse sentido, Araújo (2010) o caracteriza como um país de intensos êxodos. Com a estagnação da economia açucareira e a efervescência das extrações de minérios em Minas Gerais, o Nordeste do Século XVIII transformou-se em uma zona de repulsão populacional. Com o declínio da mineração, por sua vez, mineiros e nordestinos tomaram o rumo da expansão cafeeira, que se dava na direção do oeste paulista. De igual maneira, na metade do Século XIX, a extração de borracha no Norte do país atraiu vasto contingente de nordestinos que iam à busca de alternativas em face da estagnação regional (ARAÚJO, 2010). Ou seja, desde o final do período colonial até a constituição da República, ocorreram expressivas migrações, caracterizadas basicamente como migrações rurais.

Isso porque, como afirma Holanda (2010, p. 73), "toda a estrutura de nossa sociedade colonial teve sua base fora de meios urbanos", sendo as cidades dependentes da "civilização rural" até o marco de 1888.

Já no Século XX, o desenvolvimento da atividade industrial, fortemente concentrado na Região Sudeste e a partir da década de 1920 mais especificamente em São Paulo (conforme ilustrado na Tabela 7), é que vai comandar a economia e deslocar milhares de trabalhadores agrícolas de todo o Brasil para as principais cidades daquela região (SINGER, 1973).

Tabela 7: Distribuição percentual do valor da produção industrial brasileira (1907-1965)

\begin{tabular}{|l|ccccc|}
\hline Área & $\mathbf{1 9 0 7}$ & $\mathbf{1 9 2 0}$ & $\mathbf{1 9 3 8}$ & $\mathbf{1 9 5 8}$ & $\mathbf{1 9 6 5}$ \\
Brasil & 100,0 & 100,0 & 100,0 & 100,0 & 100,0 \\
São Paulo & 16,5 & 31,5 & 43,5 & 55,0 & 57,6 \\
Guanabara & 33,1 & 20,8 & 14,2 & 11,4 & 9,3 \\
Outros Estados & 50,4 & 47,7 & 42,3 & 33,6 & 33,1 \\
\hline
\end{tabular}

Fonte: Adaptado de Hogan; Berlinck (1974, p. 27). 
Nesse contexto, Hogan e Berlinck (1974) ressaltam que analisar as migrações internas para São Paulo corresponde, de certa maneira, a uma análise do desenvolvimento do capitalismo no Brasil, o que corrobora com o discurso de Muszynski (1986), que aponta a predominância das razões de ordem econômica na condução desses fluxos.

$\mathrm{Na}$ década de 1940, conforme explica Souza (1980?, p. 16 et seq.), 3,5 milhões de pessoas ou 8,5\% dos brasileiros estavam fora de seu Estado de nascimento. Na década de 1950 eram 5,2 milhões (10,3\%); em 1960, 12,5 milhões (18,2\%); e em 1970, 29,5 milhões, ou seja, um em cada três brasileiros já havia realizado um movimento migratório no país.

É nessa conjuntura que as migrações (considerando-se aqui tanto os deslocamentos internos quanto a imigração internacional) passam a ser o principal fator de crescimento demográfico na cidade de São Paulo, conforme ilustrado na Tabela 8. Cumpre acrescentar que Hogan e Berlinck (1974) constataram ainda que, na década de 1970, a cidade de São Paulo não era de paulistanos, visto que eles correspondiam, segundo suas estimativas, a apenas $28 \%$ do contingente populacional do município.

Tabela 8: Migração para a cidade de São Paulo (1900-1960)

\begin{tabular}{|c|c|c|}
\hline Período Intercensitário & Node migrantes & $\begin{array}{c}\text { \% do crescimento do } \\
\text { município atribuível à } \\
\text { migração }\end{array}$ \\
\hline $1900-1920$ & 218.451 & 64,4 \\
$1921-1940$ & 496.543 & 66,5 \\
$1941-1950$ & 619.755 & 70,5 \\
$1951-1960$ & 950.093 & 58,4 \\
\hline
\end{tabular}

Fonte: Adaptado de Hogan; Berlinck (1974, p. 12).

Foi depois de 1930 que, pela primeira vez, formou-se uma significativa migração interna do Nordeste e dos demais Estados da Região Leste com direção ao Estado de São Paulo. Tal processo teve início no governo de Armando Salles de Oliveira, em 1935, justamente quando decaíram bruscamente os fluxos imigratórios da Europa, havendo, inclusive, uma política migratória subvencionada para atender à demanda por mão-de-obra da cafeicultura paulista. $\mathrm{O}$ deslocamento de mineiros $\mathrm{e}$ 
nordestinos em direção às fazendas de café do interior paulista pode ser relacionado às migrações do interior paulista para a capital (e também para áreas rurais do Paraná), caracterizando a complexidade desses movimentos e delineando uma espécie de hierarquização das migrações. Isso porque, com o crescimento do parque industrial, essas migrações foram na sequência dirigindo-se, sobretudo, para as grandes cidades, conforme afirma Souza (1980?).

Diante do que foi exposto, é possível assegurar que o Século XX ficou marcado pelo início de uma nova fase de migrações, caracterizada pelos fluxos rural-urbanos, a partir dos quais o município de São Paulo destacou-se como receptor (ARAÚJO, 2010).

Nesse contexto, Durhan (1973) aponta a oposição que se configura entre o rural e o urbano, destacando que viver na cidade pressupõe padrões de consumo inacessíveis aos homens do campo, o que torna a cidade tão valorizada e faz com que a impossibilidade de se viver nela seja atribuída antes a uma "deficiência do sujeito do que do objeto" (DURHAN, 1973, p. 214).

As cidades em geral, contudo, nem sempre "oferecem condições satisfatórias de absorver imigrantes", intensificando a procura por melhores condições de vida e trabalho em grandes centros (COSTA; NOZOE; PORTO, 1986, p. 43). Com isso, um terceiro tipo de migração se configura, as migrações urbano-urbano em direção às populosas cidades, das quais São Paulo é o melhor exemplo.

É possível constatar, desde o início do Século XX até 1970, a vinda de indivíduos de diversos Estados da federação, além de muitos de outras partes do próprio Estado, conforme aponta a Tabela 9.

Importa realçar, porém, que tais dados tomam como base o último lugar de domicílio para atribuir a origem desses imigrantes, o que significa que tanto estrangeiros domiciliados no interior do Estado de São Paulo, quanto pessoas nascidas em território nacional que já tenham realizado movimentos migratórios anteriormente para tal Estado, são computados como migrações intraestaduais, superestimando tal número. O mesmo pode ocorrer em outros Estados da federação, dificultando a análise quantitativa dos fluxos ocorridos em território nacional. 
Tabela 9: Correntes migratórias para o Município de São Paulo

\begin{tabular}{|c|c|c|c|c|c|c|c|c|c|}
\hline \multirow[b]{2}{*}{ Origem } & \multicolumn{9}{|c|}{ Ano de Chegada } \\
\hline & $\begin{array}{c}1900- \\
1929\end{array}$ & $\begin{array}{l}1930- \\
1934\end{array}$ & $\begin{array}{c}1935- \\
1939\end{array}$ & $\begin{array}{c}1940- \\
1944\end{array}$ & $\begin{array}{c}1945- \\
1949\end{array}$ & $\begin{array}{c}1950- \\
1954\end{array}$ & $\begin{array}{c}1955- \\
1959\end{array}$ & $\begin{array}{c}1960- \\
1964\end{array}$ & $\begin{array}{l}1965- \\
1970\end{array}$ \\
\hline São Paulo & $77,8 \%$ & $76,3 \%$ & $69,4 \%$ & $71,7 \%$ & $54,1 \%$ & $37,6 \%$ & $30,8 \%$ & $21,6 \%$ & $22,1 \%$ \\
\hline Espírito Santo - Rio & 4,4 & 5,3 & 2 & 0 & 6,8 & 1,1 & 2,6 & 7,2 & 5,5 \\
\hline Sul & 2,2 & 2,6 & 2 & 3,3 & 5,4 & 2,2 & 6,4 & 6,4 & 5,5 \\
\hline Minas Gerais & 8,9 & 7,9 & 8,2 & 13,3 & 13,5 & 14 & 15,4 & 10,4 & 20,2 \\
\hline Pernambuco & 2,2 & 2,6 & 2 & 1,7 & 2,7 & 7,5 & 7,7 & 11,2 & 12,3 \\
\hline Alagoas & 0 & 0 & 4,1 & 1,7 & 5,4 & 9,7 & 5,1 & 11,2 & 8 \\
\hline Bahia & 2,2 & 2,6 & 10,2 & 3,3 & 8,1 & 18,3 & 17,9 & 16,8 & 17,2 \\
\hline Outros & 2,2 & 2,6 & 2 & 5 & 4,1 & 9,7 & 14,1 & 15,2 & 9,2 \\
\hline TOTAL & $100,0 \%$ & $100,0 \%$ & $100,0 \%$ & $100,0 \%$ & $100,0 \%$ & $100,0 \%$ & $100,0 \%$ & $100,0 \%$ & $100,0 \%$ \\
\hline
\end{tabular}

Fonte: Adaptado de Hogan; Berlinck (1974, p. 28).

De qualquer modo, pode-se afirmar a importância que as migrações representam para a formação da cidade de São Paulo, especialmente até a década de 1980, quando o saldo migratório ${ }^{11}$ passou a decrescer vertiginosamente, tornando-se negativo (Gráfico 3).

Segundo Perillo (1996), pode-se estabelecer uma relação direta entre os fluxos migratórios e o crescimento da cidade, sendo interessante remarcar que no período entre 1980 e 1991 os distritos da área central apresentaram taxas negativas de crescimento, enquanto a periferia exibia taxa de crescimento superior a $4 \%$ a.a..

No que se refere às influências alimentares, pode-se destacar a ampliação de possibilidades de realização culinária que esses deslocamentos podem propiciar quando se considera a riqueza contida na diversidade de hábitos e na enorme e variada biodiversidade existente no país (conforme permite entrever o mapa dos ecossistemas brasileiros - Figura 2). Nesse sentido, pode-se dizer que os deslocamentos ocorridos no interior do país foram mesclando regiões, na medida em que "parte" delas vinha também na bagagem.

\footnotetext{
${ }^{11} \mathrm{O}$ saldo migratório corresponde à diferença entre a entrada e a saída de pessoas.
} 


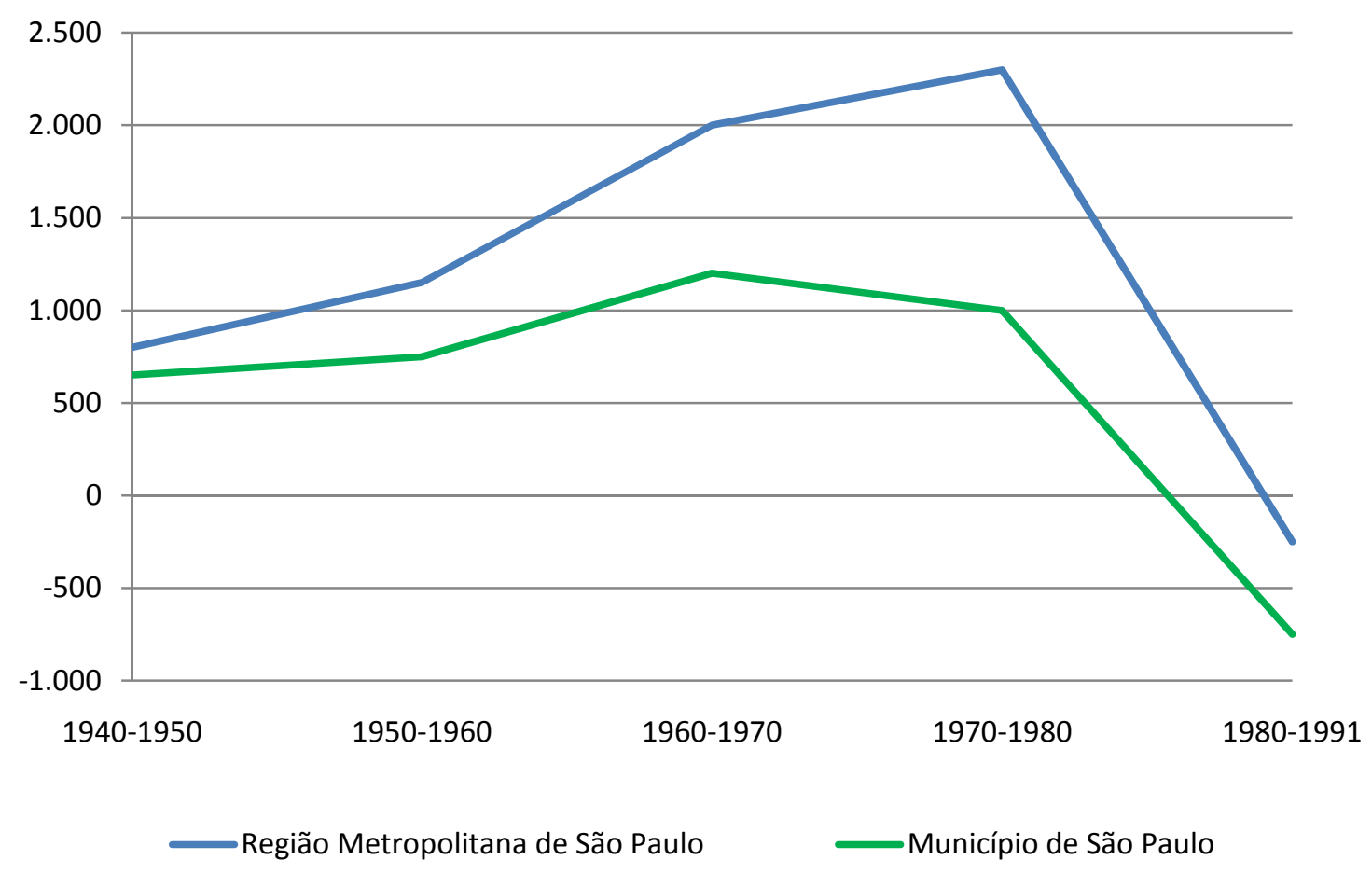

Gráfico 3: Saldos migratórios - RMSP e MSP (1940 - 1991)

Fonte: Adaptado de Perillo (1996, p. 75).

No entanto, em um país de passado colonial como o Brasil, em que, conforme aponta Dória (2009a), a elite prefere a identidade européia e tem vergonha da sua origem, tais hábitos tendem a não se propagarem da mesma maneira. Sobretudo tendo em vista que o migrante nem sempre foi tomado como igual ou teve as mesmas oportunidades de ascender socialmente que teve o imigrante, privilegiado por teorias como a de valorização da raça branca, o que igualmente dificultou a ascensão de seus hábitos (NÓBREGA; DAFLON, 2009).

Assim, apesar da importância dos fluxos migratórios internos e dos hábitos alimentares desses indivíduos na formação da cidade e da mesa paulistana, eles não recebem o mesmo destaque na medida em que não fazem parte de um comer de elite, sobretudo na constituição daquela que é a imagem gastronômica que se quer veicular da cidade, fazendo com que se mantenham mais restritos a esses próprios grupos de pessoas. 


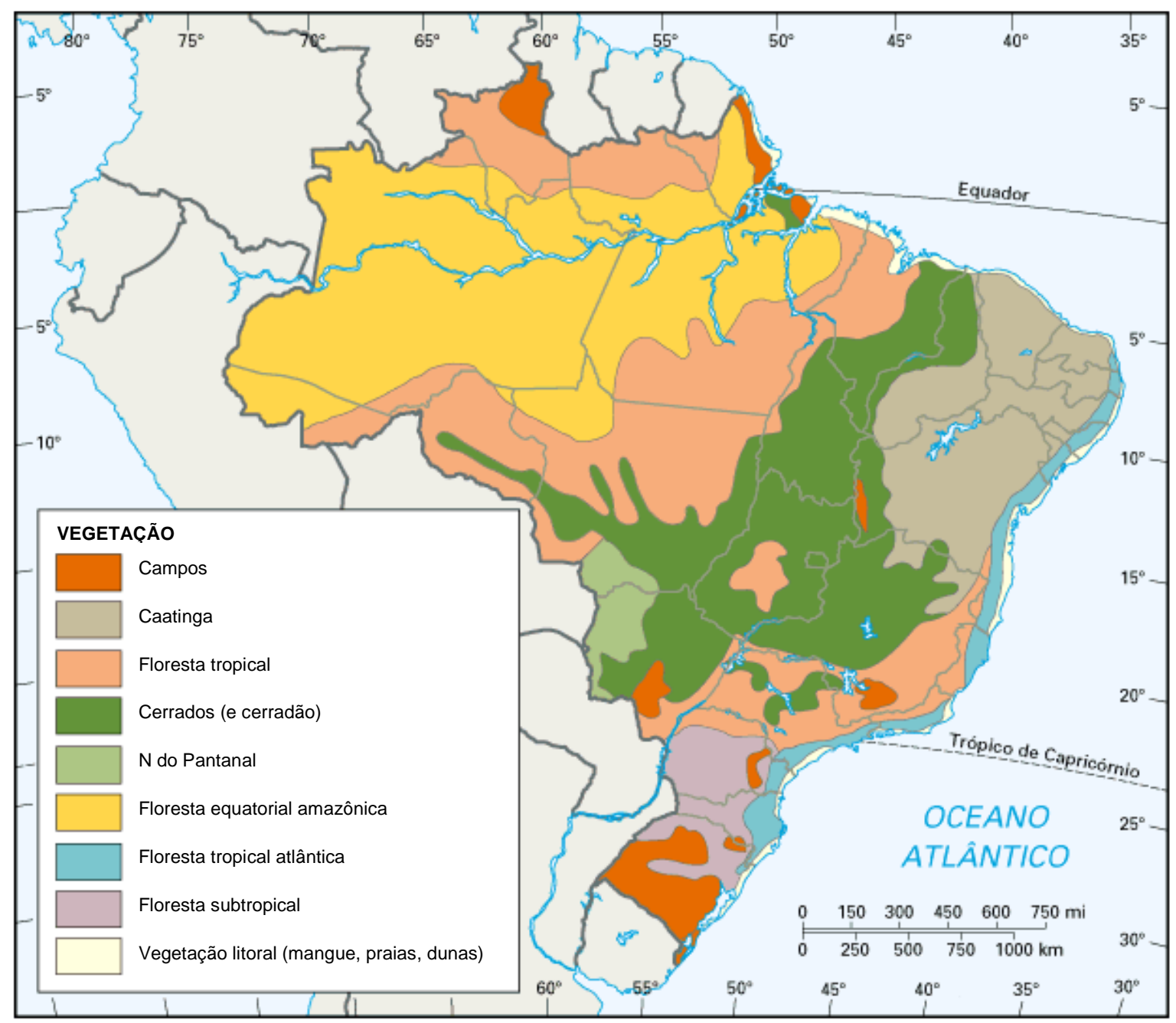

Figura 2: Ecossistemas brasileiros

Fonte: Adaptado de Théry; Mello (2005, p. 61).

Dessa forma, curiosamente, é no momento em que os fluxos migratórios para São Paulo decrescem visivelmente e delineia-se uma migração de retorno (EXPANSÃO, 2010; BAENINGER, 2005) que essas comidas regionais recolocam-se no cenário e na oferta gastronômica paulistana, como início de uma nova fase de celebração daquilo que é brasileiro (DÓRIA, 2009a; BARBOSA, 2006), questão a ser entendida dentro do contexto de um mercado global, a ser abordado na sequência. 


\subsection{Globalização}

A globalização é um fenômeno amplamente discutido na literatura acadêmica (BARBER, 1996; CASTELLS, 1999; CAPRA, 2002; CHAUNU, 1995; FRIEDMAN, 1997; GIDDENS, 1999; GRAY, 2010; HANNERZ, 1997; HUNTINGTON, 1993; LATOUCHE, 2006; MITTELMAN, 2000; MYIOSHI, 1998; RITZER, 2000; ROBERTSON, 1992; ROBERTSON, 2004; WATERS, 2001), constando mais de 2900 registros sobre o tema no catálogo digital do Sistema Integrado das Bibliotecas da Universidade de São Paulo (DEDALUS, 2010).

São diversas as acepções que the são concedidas, nos âmbitos econômico, político, social ou cultural, havendo, pois, divergências no que concerne à definição do termo, escala, cronologia, trajetória e efeitos entre os estudiosos que se dedicam ao tema (STEGER, 2009; PIETERSE, 2007; HELD et al., 1999).

A globalização pode ser considerada como um processo (ou um conjunto de processos) histórico e entendida por meio da transformação da relação espaçotemporal, sendo moldada pelas mudanças tecnológicas e caracterizada pela conexão de pessoas, culturas e economias (PIETERSE, 2007; STEGER 2009; GRUZINSKI, 1999).

Para o linguista Noam Chomsky (apud ALONSO, 2002), o conceito de globalização em si é neutro, visto que significa simplesmente a integração internacional. Segundo ele, "nenhuma pessoa em seu juízo seria contrária à globalização. A questão é em que forma adotá-la".

Assim, o ponto de discordância sobre as consequências positivas e negativas da globalização recai sobre a criação de contradições e paradoxos, na medida em que seu modus operandi contrapõe o local ao exógeno, em um processo dialético, cuja síntese é a própria expressão da globalização (PIETERSE, 2007; HARVEY, 2004; STEGER, 2009).

Então, encarar a globalização como um processo histórico e que ganha corpo com as revoluções tecnológicas leva a refletir igualmente sobre as transformações pelas quais vem passando a sociedade no curso desse processo.

Com o incremento de novas tecnologias, em especial no que tange às telecomunicações e ao transporte, as barreiras geográficas estão caindo e a "tirania da distância" se reduz (HARVEY, 2004; VARGAS, 1998; HALL et al., 2003) de tal 
modo que se tornou possível almoçar em Paris, jantar em Nova lorque ou participar de um seminário sobre gastronomia na Espanha sem sequer sair de São Paulo.

Os fluxos financeiros transcendem os comerciais, o comércio está mais livre (com o progressivo abandono das políticas protecionistas), os blocos econômicos proliferam-se e as redes transnacionais concentram um volume cada dia maior de transações (SCOTT et al., 2001; SASSEN, 1998; CASTELLS, 1999), a exemplo das grandes cadeias supermercadistas.

O incremento tecnológico e a evolução dos meios de comunicação e de transporte, decorrentes da revolução tecnocientífica, parecem consolidar a tendência de uniformização do território (VARGAS, 1998), de maneira similar ao que ocorre com os shopping centers, onde aquele de Buenos Aires é semelhante ao de São Paulo ou da Cidade do México.

Segundo Castells, a revolução tecnocientífica faz emergir uma nova "sociedade em rede", em que a geração de novos conhecimentos, o poder político e militar, a produtividade econômica e os meios de comunicação de massa estão todos ligados a redes globais de informação e riqueza (1999, p. 565), o que conduz a uma reestruturação do espaço.

É neste contexto que Sassen (1998) pontua a re-hierarquização das cidades, destacando o papel das cidades globais.

\footnotetext{
As cidades globais da atualidade são: (1) pontos de comando na organização da economia mundial; (2) lugares e mercados fundamentais para as indústrias de destaque do atual período, isto é, as finanças e os serviços especializados destinados às empresas; (3) lugares de produção fundamentais para essas indústrias, incluindo a produção de inovações. (SASSEN, 1998, p. 17).
}

Scott e seus colegas (2001) afirmam que esta nova organização social e política do espaço "consiste, sobretudo, na hierarquização de escalas territoriais interpenetradas de atividade econômica e de relações de governança, variando do global até o local e na qual o sistema emergente de cidades-regiões globais se destaca" (SCOTT et al., 2001, p. 12). Para Pieterse (2007), é o que pode ser entendido como "integração hierárquica" ou "inclusão assimétrica".

Dentro dessa visão, São Paulo se destaca, sem dúvida, como líder nacional, inclusive no setor da gastronomia. A cidade, que era apontada por Sassen (1998) já no final do século XX como uma cidade global, destacando-se entre as 50 principais 
cidades do planeta e ocupando liderança na América Latina, tende a se destacar ainda mais no contexto internacional com as mudanças nas direções dos fluxos que modelam a economia política que está se delineando na pós-crise americana, com crescente importância dos "BRICS" (SHESHABALAYA, 2006).

Mas é necessário refletir que, mesmo quando se fala em cidades globais, não se pode imaginar a cidade como algo homogêneo, assim como a globalização também não o é (PIETERSE, 2007). Ela é cheia de contradições, visto que somente algumas dessas centralidades conectam-se, ainda que, para que elas se destaquem e o processo perdure, a articulação com as outras áreas seja imprescindível.

Transferindo essa leitura para o setor de alimentação fora do lar, percebe-se, claramente, na cidade de São Paulo, a concentração de restaurantes nas áreas mais ricas, quer seja em função da renda de seus moradores, quer dos empregos qualificados e de maior remuneração. Contudo, esses estabelecimentos, para se manterem em funcionamento, dependem de mão-de-obra que, por vezes, habita as periferias da cidade e sequer tem acesso a esse tipo de estabelecimento.

Em confluência com tal ideia, Scott e demais autores (2001) destacam três efeitos essenciais provocados pela globalização e pela reestruturação espacial, os quais podem ser resumidos em: 1) a migração em larga escala para as cidadesglobais provoca crescente heterogeneidade tanto demográfica quanto cultural. Tal heterogeneidade cultural carrega consigo não somente novas e criativas oportunidades para a mobilidade e justiça social, mas também perigos explosivos; 2) mudança no tecido urbano das cidades-regiões globais que estão se tornando cada vez mais aglomerações policêntricas ou multiagrupadas, em um processo complexo e simultâneo de descentralização e recentralização da cidade-região; 3) ampliação da disparidade entre opulência e pobreza em termos econômicos, sociais e espaciais, causada pelo crescimento de empregos bem remunerados em grandes cidades e proliferação dos empregos marginais, sem qualificação.

De maneira aparentemente contraditória, mas absolutamente coerente, as cidades-regiões globais representam, ao mesmo tempo, "o melhor e o pior do processo de desenvolvimento" (SCOTT et al., 2001, p. 22).

As análises feitas sobre globalização frequentemente enfatizam os aspectos econômicos e tecnológicos desse fenômeno como uma das faces da evolução do sistema capitalista e posicionam o capitalismo como orientador desse processo 
(CAPRA, 2002). Tendo por referência o tema deste trabalho, é importante resgatar o debate sobre a relação estabelecida entre globalização e cultura que aí toma forma.

A globalização propicia o alargamento da comunicação (SANTOS, 2000; MORAES, 2004), abrindo assim o horizonte de um mercado global. Nesse sentido, deve-se notar que "o espaço econômico de competição mudou de forma e escala no decorrer do tempo" (HARVEY, 2004, p. 149). Por um longo período, os elevados custos e dificuldades de transporte protegeram artesãos e comerciantes nos mercados locais, garantindo seus privilégios monopólicos, ou seja, protegia-os da concorrência (Harvey, 2004). Da mesma maneira, até o final do Século XIX, localizações estratégicas do ponto de vista geográfico favoreciam o desenvolvimento das atividades comerciais, havendo uma alteração dos centros de dominação econômica em virtude das necessidades do setor produtivo (VARGAS, 1998).

Com a segunda revolução industrial, no entanto, começou a se delinear uma forte tendência à homogeneização "tanto no que se refere ao mercado de consumo, quanto à localização dos centros de produção", isto é, uma homogeneização de "gostos, hábitos, valores, crenças e territórios", diante da qual as condições de acesso construídas passaram a exercer maior importância como fator locacional (VARGAS, 1998, p. 10).

Nesse contexto, de "uniformidade de atributos locacionais", em que a localização geográfica não é mais determinante e, portanto, as cidades passam a empreender esforços de constituição de marca como forma de se projetar, as singularidades e especificidades, "os atributos do lugar, o regionalismo, os valores étnicos" passam a ser valorizados como formas de diferenciação (VARGAS, 1998, p. 12). Isso porque, segundo Harvey, "quando diminuem os privilégios monopólicos de determinada fonte, testemunhamos uma variedade de tentativas de preservá-los e reuni-los por outros meios" (HARVEY, 2004, p. 147).

Deve-se observar que essa busca por rendimentos monopólicos inerente ao sistema capitalista carrega consigo algumas contradições, entre as quais merecem destaque: 1) quanto mais fácil de ser comercializado um produto torna-se, menos único e especial ele parece; 2) "até os globalizadores mais ávidos apoiarão avanços locais que tenham o potencial de gerar rendimentos monopólicos, ainda que o efeito de tal apoio seja produzir um clima político local antagônico à globalização" (HARVEY, 2004). 
Ficam claras as vantagens econômicas das diferenças culturais e locacionais (como fonte de rendimentos monopólicos) perante a homogeneização, o que instiga a reflexão sobre a dinâmica e os possíveis impactos da globalização, principalmente quando se coloca em pauta quem vai ou quem pode captar os benefícios oriundos de um possível acúmulo de marcas distintivas e aumento do quociente de capital simbólico coletivo. Nesse sentido, Harvey (2004) afirma que as "intervenções culturais podem tornar-se uma arma potente de luta de classes" (HARVEY, 2004, p. 165).

Interessante perceber, pois, como a dinâmica em torno do alimento e sua oferta reflete essa dialética da globalização (HARVEY, 2004), conduzindo, paralelamente, à uniformização e a uma busca por elementos singularizantes.

Não restam dúvidas a respeito de a globalização carregar consigo certa tendência homogeneizadora. No que tange aos hábitos e aos consumos alimentares, a melhor caracterização ficaria por conta do efeito chamado McDonaldização (RITZER, 2000; SCHLOSSER, 2001), utilizado como sinônimo de racionalização (RITZER, 2000) ou padronização (SCHLOSSER, 2001) do mundo contemporâneo. Trata-se de uma analogia à maior cadeia varejista do mundo, que tem seu símbolo mais reconhecido do que a cruz cristã (SCHLOSSER, 2001) e que vem sendo utilizada corriqueiramente em uma postura crítica em relação aos acontecimentos, questionando 0 caráter estritamente funcional agregado à alimentação nos restaurantes e lanchonetes fast food e à desvinculação do alimento à sua origem e até mesmo preparação.

No entanto, os limites dessa homogeneização precisam ser observados. Mesmo na indústria fast food, em que teoricamente o modelo é simplesmente exportado, deve-se obedecer a uma adequação mínima aos costumes locais. Notase nesse fenômeno de adequação o conceito denominado por Robertson (1992) de glocalização, que nada mais é do que a adaptação aos gostos e culturas locais dos produtos importados.

Como exemplos dessa adequação, podem ser citadas as diversas opções de hambúrgueres vegetarianos encontrados na Índia, onde a vaca é animal sagrado e o fato de os molhos comercializados no México serem mais picantes. Esses dois casos dão indícios do que Steger (2009) chama de "empréstimo cultural", tratandose de uma complexa relação entre o global e o local. 
Talbott (1995), ao avaliar a implantação da rede em Moscou também defende que o McDonald's ali deveria ser entendido dentro dos limites da "localização global", porque há diferenças no cardápio, nas formas de gestão e até mesmo no controle de clientes, que ali permanecem por longos períodos no restaurante.

Já na China, em que pais querem que seus filhos conectem-se com o mundo exterior, Watson (2007) defende que o McDonald's pode ser encarado por muitos deles como uma importante parada rumo aos laboratórios do MIT ou de Harvard, o que traz à tona o questionamento das diferentes relações estabelecidas com as coisas de acordo com o acesso que se tem a elas.

Pode-se destacar, ainda, que também nas cadeias de fast food é possível visualizar a miscigenação alimentar abordada alguns parágrafos atrás. Nesse sentido, Pieterse (2007) ressalta que os fast foods americanos servem comida alemã (hambúrgueres e salsichas) com elementos franceses (batatas fritas e molhos) e italianos (pizzas), num estilo americano de gestão. Assim, faria mais sentido considerar que "o McDonald's localiza globalmente uma variedade de formas". (PIETERSE, 2007, s.p.).

Também é verdade que, com as novas tecnologias, o ritmo estabelecido principalmente pelas grandes metrópoles e a mudança no estilo de vida das pessoas, a dinâmica ao redor da comida também foi modificando-se. Basta observar que os supermercados (cujo surgimento é reflexo direto das revoluções industriais) passaram a ser responsáveis pela maior parcela das vendas nacionais de produtos de grande consumo (SANTOS; SILVEIRA, 2003) e que, como aponta Barbosa (2006), o consumo doméstico de itens regionais é baixíssimo nas regiões metropolitanas.

Nessa perspectiva, se, por um lado, falar em McDonaldização parece certo exagero, por outro, não se pode deixar de refletir sobre uma possível estandardização do gosto (NOSSITER, 2009), com produtos que se assemelham em busca daquilo que seria o gosto mais comum ou mais fácil de agradar.

Nesse sentido, Lucki (2010) destaca existir uma popularização de vinhos "chardonnay" e "cabernet sauvignon" que, mesmo produzidos em diferentes partes do mundo, assemelham-se, apontando na direção de um padrão mundial de vinho. No entanto, se tal popularidade incorre no risco da bebida "se tornar um produto cada vez mais monótono, cada vez mais industrial, sem riscos, mas também sem charme", deve-se notar que dificilmente esses vinhos vão revelar alguma "mágica", 
algo que possa realmente surpreender os consumidores, deixando igualmente aberto um lugar no mercado para aqueles vinhos com personalidade, sejam eles compostos por uvas menos populares ou que reflitam seu terroir, sua origem (LUCKI, 2010, p. 26).

De maneira similar, se, por um lado, as comidas prontas e fast food alcançam maior representatividade na rotina das pessoas a cada dia, por outro, abrem espaço para que outras experiências (sobretudo as experiências ditas gastronômicas) adquiram maior valor agregado e uma roupagem mais lúdica, de acordo com o discurso que carregam consigo. Segundo Schluter (2003, p. 44), "com o surgimento do conceito de valorização das diferenças regionais e nacionais em um mundo globalizado, encontra-se em franco crescimento o interesse pelos restaurantes étnicos" (SCHLÜTER, 2003, p. 44).

Em adição a isso, Dória (2009a, p. 10) afirma que, se a nossa alimentação hoje é "um capítulo do que se passa pelo mundo", justamente nos grandes centros, onde a pressão de outras culinárias é mais forte, o que parece é que se vive uma nova fase de celebração da culinária brasileira.

Hoje, muitos chefs têm buscado trabalhar com produtos tradicionais de determinada localidade e ingredientes brasileiros ainda pouco conhecidos, utilizando-os como marcas distintivas do seu trabalho. E São Paulo, seja como cidade global (SASSEN, 1998), seja como o polo gastronômico brasileiro (GUIA QUATRO RODAS, 2010) está no centro desse movimento.

Perante essa necessidade de singularização, os títulos de reconhecimento do patrimônio, os direitos de propriedade intelectual e os elementos culturais se destacam (CARVALHO, 2010; HARVEY, 2004). Isso "porque alegações de singularidade e autenticidade podem ser mais bem articuladas como afirmações culturais distintas e não duplicáveis" (HARVEY, 2004, p. 149).

Assim, a singularização é ao mesmo tempo reflexo das qualidades do produto e resultado dos esforços empreendidos para diferenciá-lo (HARVEY, 2004).

Comidas podem, mediante o uso de atributos culturais, de elementos de autenticidade, garantia de origem e denominações de origem, serem transformadas em "marcas", constituindo um elemento forte de identidade local e de produto.

No Brasil, são as Indicações Geográficas que oferecem essa possibilidade e garantem tal proteção do ponto de vista legal com a Lei da Propriedade Industrial, $\mathrm{n}^{\circ}$ 9.279 (INPI, 2010). Divididas em categorias como "Denominação de Origem" e 
"Indicação de Procedência", essas nomenclaturas permitem a "identificação de um produto ou serviço como sendo originário de um local, região ou país", a saber, a primeira delimita uma área geográfica, precisamente demarcada, produtora de determinado produto influenciado por suas características geográficas (solo, subsolo, vegetação), meteorológicas (mesoclima) e humanas (cultivo, tratamento, manufatura); enquanto a segunda simplesmente aponta determinada área geográfica conhecida por produzir, extrair ou fabricar determinado item, ou prestar algum serviço (INPI, 2010, online).

A primeira indicação geográfica genuinamente brasileira reconhecida pelo Instituto Nacional da Propriedade Industrial (INPI), o órgão federal brasileiro responsável pela criação de normas atinentes e pela regulação da Propriedade Intelectual, foi o Vale dos Vinhedos. A conhecida região da Serra Gaúcha, representada pela Associação dos produtores de vinhos finos do Vale dos Vinhedos (APROVALE), com incentivo da Empresa Brasileira de Pesquisa Agropecuária (EMBRAPA), requereu a indicação de procedência da produção vinícola da região, como um primeiro passo para, quando fortalecidas as regras de controle de produção e fundamentada sua excelência, requerer o reconhecimento de suas áreas como "Denominação de Origem" (APROVALE, 2008).

As informações e garantias em relação ao produto ganham destaque, à proporção que as escolhas tornam-se mais sociais, como é no caso da gastronomia - que está atrelada à busca do prazer e não propriamente à satisfação da necessidade básica vital em si.

Corroborando tal ideia, Megido (2000, p. 418) explica que:

As pessoas urbanas, consumidoras finais - através das organizações de defesa dos consumidores, educação e esclarecimento sobre qualidade e segurança alimentar - levam cada vez mais em consideração a linha da origem dos alimentos, desde sua concepção genética até o consumo final. Significa que guardam intuitivamente/racionalmente nas suas mentes uma relação sistêmica com insumos, meio ambiente, qualidade da origem, conservação e transporte, apresentação no ponto de venda e na mesa.

As indicações geográficas constituem, sob esse ponto de vista, uma forma de fácil assimilação e rápido reconhecimento, por parte dos consumidores, de uma qualidade conhecida de determinado produto. Ao proteger a designação "Vale dos Vinhedos", por exemplo, esta poderá ser estampada nos produtos à venda, favorecendo a escolha pelo consumidor final que confiará no produto sem maiores 
averiguações. Nesse sentido, a valorização do processo de produção e do modo de comercialização pode transformar a imagem de determinados produtos.

Atualmente, na era em que o comércio atinge picos nunca antes imaginados e a possibilidade de escolha do consumidor final é infinita, tem-se observado uma preocupação crescente com a qualidade do que se está consumindo, aliada à disponibilidade de pagar mais pelas garantias oferecidas. Trata-se de uma espécie de seguro de consumo combinada aos aspectos de satisfação social e psicológica. Dessa forma, pode-se dizer que:

cada vez mais, o consumo de alimentos está associado à quantidade e à qualidade de informações na mente dos consumidores. As pessoas estão consumindo não apenas por necessidade, mas por valores e identificação de papéis (MEGIDO, 2000, p. 424).

Se a capacidade de inovação depende diretamente do repertório de ingredientes e de produtos utilizados na experimentação gastronômica (DÓRIA, 2009a), o tratamento dado a esses elementos, como ícones de diferenciação, merece cada vez mais atenção.

No Brasil, ainda está se estabelecendo a cultura de identificação do produto de acordo com sua zona de produção, em decorrência das poucas, esparsas e recentes aplicações de Indicação Geográfica - até o presente momento são apenas oito os registros de indicações geográficas brasileiras, sendo todas elas "Indicações de Procedência" (INPI, 2010). Entretanto, em locais como a França e a Itália, em que esse procedimento acontece há mais tempo e em maior escala, são profundas as marcas de identidade regional (SOPEXA, 2009; LOPES, 2010).

O champagne é um ótimo exemplo de identificação entre produto (de boas e específicas qualidades) e região produtora. A caracterização do produto é tão forte e tão difundida que se aproxima da acepção comercial de marca de um produto, distinta apenas pelo seu caráter de coletividade.

Nesse sentido, Dória (2009a, p. 76) pontua:

Se o enraizamento brasileiro dos ingredientes pode ser convertido numa "vantagem competitiva" é preciso ver em que sentido esse confronto se processará (...). O "reencantamento do mundo" depende de um diálogo intenso entre ciências, técnicas, tradições e culturas que ponham em destaque aquilo que possa ser ressignificado. 
Seria outra maneira de pensar a criação/recriação de referências, gerando atratividade e, consequentemente, levando para algumas áreas os frutos dos rendimentos monopólicos advindos do capital simbólico que Harvey (2004) enfatiza e, consequentemente, de "atributos de centralidade" (TOURINHO, 2006).

Do mesmo modo que as várias faces da globalização afetaram a produção, a distribuição e o consumo de alimentos, esses mesmos elementos podem ser utilizados para promover alimentos e maneiras de produções locais, redefinir aspectos de identidade e contribuir para o desenvolvimento. 



\section{SÃo PAULO: POLO DE ALIMENTAÇÃO}

No mesmo século XIX que São Paulo vê o tripé feijão, farinha e carne seca ganhar a companhia de hábitos imigrantes que aqui desembarcaram e começaram a ser incorporados (PINTO, 2010), a cidade começa a se deslocar da realidade das comidas de tabuleiro e da informalidade do comércio de rua para a dos primeiros restaurantes, cafés e confeitarias (SILVA, 2008 ; BARBUY, 2006).

Já o século $X X$ que assiste aos intensos fluxos migratórios e à multiplicação desse contingente, em virtude do crescimento da população, vai ser palco também para o florescimento da indústria de alimentos, a transformação do mercado varejista, o aumento no consumo de alimentos fora do lar, dentre tantas outras mudanças no comportamento do consumidor, consolidando São Paulo como principal polo gastronômico do Brasil.

Assim, em complementação ao panorama exposto nos capítulos anteriores, será abordada a importância da cidade de São Paulo no contexto nacional, salientando-se também alterações no mercado de alimentos na cidade e no Brasil.

\subsection{A Importância de São Paulo}

A relevância da cidade de São Paulo como principal polo de alimentação do Brasil pode ser avaliada tomando por base alguns indicadores do município e de sua região metropolitana, ao demonstrarem a magnitude e a importância desse mercado no cenário nacional, não somente no ramo de alimentação mas também como centro econômico-financeiro do país. 


\subsubsection{Indicadores sociodemográficos e negociais}

O Município de São Paulo (MSP) é o maior entre os 5.565 do Brasil, como também entre os do Hemisfério Sul, com população da ordem de 11 milhões de habitantes. Quando considerada sua região metropolitana, atinge cerca de 20 milhões de habitantes, caracterizando São Paulo como a terceira metrópole mais populosa do mundo, depois apenas de Tóquio e Cidade do México (IBGE, 2010a).

Em termos econômicos, o Município de São Paulo destaca-se pela diversidade de atividades e tamanho da riqueza produzida. Em relação ao Produto Interno Bruto (PIB) nacional, uma análise dos anos de 2004 a 2008 aponta que a cidade foi responsável, neste período, por uma participação média que ultrapassa 10\% do total do país (IBGE, 2010d). Embora a indústria tenha assumido grande responsabilidade no desenvolvimento da capital paulista, o setor terciário é o de maior peso na economia do município.

O destaque que o Município de São Paulo assume no contexto nacional pode ser evidenciado por meio de indicadores de população, renda, emprego por setor de atividade e volumes bancários, entre outros, conforme apresentado na Tabela 10.

A cidade concentra $6 \%$ da população nacional (e cerca de $20 \%$ da população brasileira com maior poder aquisitivo - classe A1), é geradora de $12 \%$ dos empregos e $15 \%$ da massa salarial formal. Ainda sob essa ótica, no que diz respeito aos empregos formais do setor de alimentos, percebe-se que a cidade deixou a fase industrial (reúne apenas 2,8\% dos empregos brasileiros na indústria alimentícia) para se concentrar no comércio e nos serviços. Apresenta significativa participação de $9 \%$ tanto no varejo como no atacado alimentar, mas é no setor de serviços de alimentação (restaurantes, bares, lanchonetes, catering, bufê, entre outros) que mostra toda a sua força, com expressivos $15,1 \%$ dos empregos do país.

Paralelamente, uma observação sobre os indicadores do setor bancário demonstra a dominância do município diante do total nacional, concentrando mais de $32 \%$ do volume de depósitos e empréstimos. 
Tabela 10: Indicadores do município de São Paulo

\begin{tabular}{|c|c|c|c|}
\hline \multirow{2}{*}{ INDICADORES } & \multirow{2}{*}{$\begin{array}{c}\text { BRASIL } \\
\text { № }\end{array}$} & \multicolumn{2}{|c|}{ MSP } \\
\hline & & № & $\begin{array}{c}\% \\
\text { Brasil }\end{array}$ \\
\hline \multicolumn{4}{|c|}{ POPULAÇÃO POR CLASSE ECONÔMICA - 2010 (a) } \\
\hline $\mathrm{A} 1$ & 803.546 & 152.784 & 19,0 \\
\hline $\mathrm{A} 2$ & 5.635 .683 & 857.481 & 15,2 \\
\hline B1 & 11.147 .637 & 1.480 .789 & 13,3 \\
\hline B2 & 21.532 .572 & 2.396 .619 & 11,1 \\
\hline C & 71.081 .583 & 4.849 .480 & 6,8 \\
\hline $\mathrm{D}+\mathrm{E}$ & 80.531 .673 & 1.507 .217 & 1,9 \\
\hline Total & 190.732 .694 & 11.244 .369 & 5,9 \\
\hline \multicolumn{4}{|c|}{ EMPREGOS FORMAIS - 2010 (b) } \\
\hline Indústria & 7.306 .805 & 511.473 & 7,0 \\
\hline Comércio & 7.975 .248 & 855.048 & 10,7 \\
\hline Serviços & 14.348 .975 & 2.291 .471 & 16,0 \\
\hline Construção Civil/ Outros & 4.023 .914 & 292.859 & 7,3 \\
\hline Públicos & 7.615 .872 & 948.150 & 12,4 \\
\hline Total & 41.270 .814 & 4.899 .001 & 11,9 \\
\hline \multicolumn{4}{|c|}{ EMPREGOS FORMAIS - SETOR DE ALIMENTOS - 2009 (b) } \\
\hline Indústria Alimentícia & 1.452 .803 & 40.448 & 2,8 \\
\hline Varejo de Alimentos & 1.773 .282 & 160.135 & 9,0 \\
\hline Atacado de Alimentos & 409.859 & 37.081 & 9,0 \\
\hline Serviços de Alimentação & 1.122 .467 & 169.526 & 15,1 \\
\hline \multicolumn{4}{|c|}{ INDICADORES DO SETOR BANCÁRIO - Jun/2010 (c) } \\
\hline Depósitos à Vista ( $\mathrm{R} \$$ mil) & 161.525 .415 & 37.046 .130 & 22,9 \\
\hline Depósitos Total (R\$ mil) & 1.171.710.977 & 332.424 .892 & 28,4 \\
\hline Empréstimos ( $\mathrm{R} \$$ mil) & 1.306 .516 .567 & 454.838 .349 & 34,8 \\
\hline № Agências & 19.405 & 2.381 & 12,3 \\
\hline \multicolumn{4}{|c|}{ FROTA DE VEÍCULOS - Dez/2010 (d) } \\
\hline Automóveis & 37.188 .341 & 4.617 .635 & 12,4 \\
\hline Outros Veículos & 27.629 .632 & 1.772 .457 & 6,4 \\
\hline
\end{tabular}

Fonte: Elaborado pela autora. (GEOGRAFIA DE MERCADO, 2010 (a); MINISTÉRIO DO TRABALHO E EMPREGO, 2011 (b); BANCO CENTRAL DO BRASIL, 2010 (c); DENATRAN, 2011 (d)).

Quando se trata da distribuição de renda, os dados da Pesquisa Nacional por Amostra de Domicílios de 2009 (IBGE, 2010c) permitem comparar a Região Metropolitana de São Paulo (RMSP) ${ }^{12}$ com o total Brasil. Embora ocorra na RMSP grande disparidade de renda, ela é menos acentuada do que a média nacional. Merece destaque o percentual de concentração nos dois extratos superiores de

${ }^{12}$ A Pesquisa Nacional por Amostra de Domicílios não apresenta informações desagregadas por município da RMSP. 
renda (acima de 10 e de 20 salários mínimos), bastante acima da média Brasil. Os dados apontam, ainda, que aproximadamente $17 \%$ das pessoas ocupadas com rendimento mensal superior a 10 salários mínimos estão na RMSP.

Tabela 11: Rendimento mensal das pessoas ocupadas: Brasil e RMSP

\begin{tabular}{|c|c|c|c|c|c|c|}
\hline \multirow{2}{*}{$\begin{array}{c}\text { Classes de } \\
\text { Rendimento Mensal } \\
\text { (em Salários Mínimos) }\end{array}$} & \multicolumn{3}{|c|}{ Brasil } & \multicolumn{3}{|c|}{$\begin{array}{l}\text { Região Metropolitana } \\
\text { de São Paulo }\end{array}$} \\
\hline & $\begin{array}{c}\text { № } \\
\text { (em mil) }\end{array}$ & $\%$ & $\begin{array}{c}\% \\
\text { Acumulado }\end{array}$ & $\begin{array}{c}\text { № } \\
\text { (em mil) }\end{array}$ & $\%$ & $\begin{array}{c}\% \\
\text { Acumulado }\end{array}$ \\
\hline Mais de $20 \mathrm{SM}$ & 726 & 0,7 & 0,7 & 117 & $y, 1$ & 1,1 \\
\hline Mais de 10 a $20 \mathrm{SM}$ & 2.125 & 2,1 & 2,8 & 352 & 3,3 & 4,4 \\
\hline Mais de 5 a 10 SM & 5.513 & 5,5 & 8,3 & 888 & 8,3 & 12,6 \\
\hline Mais de 3 a 5 SM & 9.197 & 9,1 & 17,4 & 1.350 & 12,6 & 25,2 \\
\hline Mais de 2 a 3 SM & 10.776 & 10,7 & 28,0 & 1.535 & 14,3 & 39,5 \\
\hline Mais de 1 a 2 SM & 31.357 & 31,0 & 59,0 & 3.644 & 33,9 & 73,4 \\
\hline Até $1 \mathrm{SM}$ & 27.497 & 27,2 & 86,2 & 1.165 & 10,8 & 84,2 \\
\hline Sem rendimento & 11.868 & 11,7 & 98,0 & 1157 & 10,8 & 95,0 \\
\hline Sem declaração & 2052 & 2,0 & 100,0 & 536 & 5,0 & 100,0 \\
\hline Total & 101.111 & 100,0 & & 10.744 & 100,0 & \\
\hline
\end{tabular}

Fonte: Elaborado pela autora (IBGE,2010c).

\subsubsection{IPC - Índice de Potencial de Consumo}

Outro importante índice de referência é o denominado Índice de Potencial de Consumo (IPC), que retrata o quanto as famílias destinam de recursos para os gastos de consumo e investimento. Tendo como referência o IPC, a cidade de São Paulo representa $11,2 \%$ das despesas totais das famílias em relação ao Brasil, sendo responsável por 8,2\% das despesas com alimentação dentro do domicílio e $10,2 \%$ das despesas com alimentação fora do domicílio, o que tem grande representatividade quando considerado que sua população representa menos de $6 \%$ do total do Brasil (GEOGRAFIA DE MERCADO, 2010). 
Considerando a distribuição do IPC e da população por classe econômica ${ }^{13}$, verifica-se que, enquanto a "Classe A" representava 9\% da população em 2008, o seu potencial de consumo para alimentos no lar atingia $21 \%$ e para fora do lar, mais de $29 \%$ (Gráfico 4).

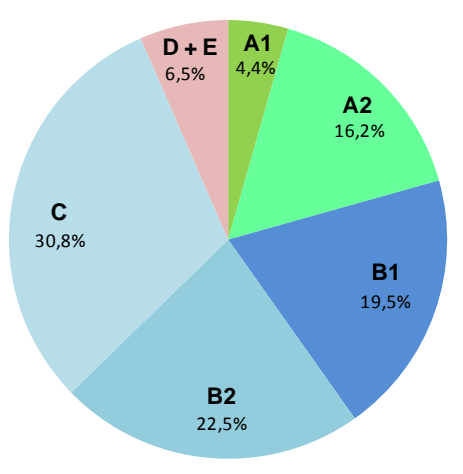

IPC-ALIMENTAÇÃo DENTRO DE CASA

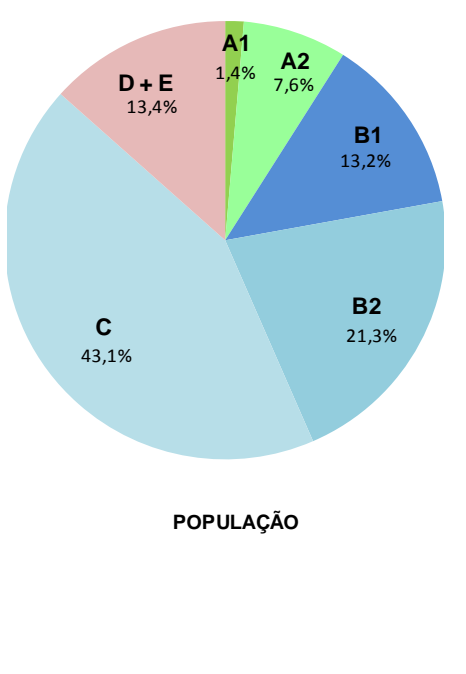

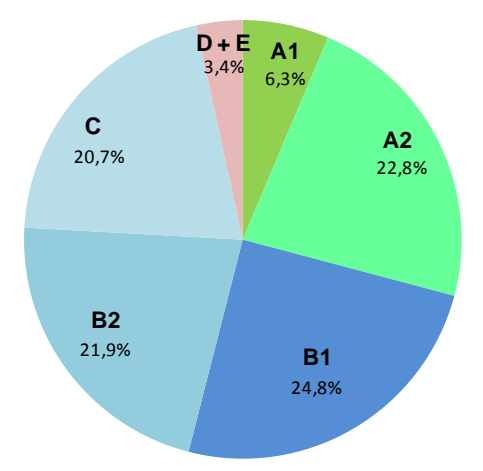

IPC - ALIMENTAÇÃo FORA DE CASA

\section{Gráfico 4: Distribuição do IPC e população por classe econômica em São Paulo}

Fonte: Elaborado pela autora (GEOGRAFIA DE MERCADO, 2010).

A distribuição do "IPC - Alimentação fora do lar" por distrito da cidade de São Paulo (Figura 3) evidencia que aqueles de maior potencial são justamente onde ocorre a concentração de restaurantes de destaque (Figura 9). Pode ser enfatizado, ainda, que essas áreas são as de maior renda e, via de regra, as com maior volume de empregos e melhor remuneração.

${ }^{13}$ O critério de classificação denominado Brasil/2008 foi conduzido pela ABEP - Associação Brasileira das Empresas de Pesquisa, o qual teve como objetivo discriminar grandes grupos de acordo com sua capacidade de consumo de produtos e serviços. Assim, foram classificados os domicílios assumindo como pressuposto que a classe econômica é uma característica familiar. $O$ sistema foi baseado em pontuação considerando a posse de bens (automóvel, TV, rádio, banheiro, máquina de lavar, geladeira, freezer, DVD), número de empregadas domésticas e instrução do chefe de família. 


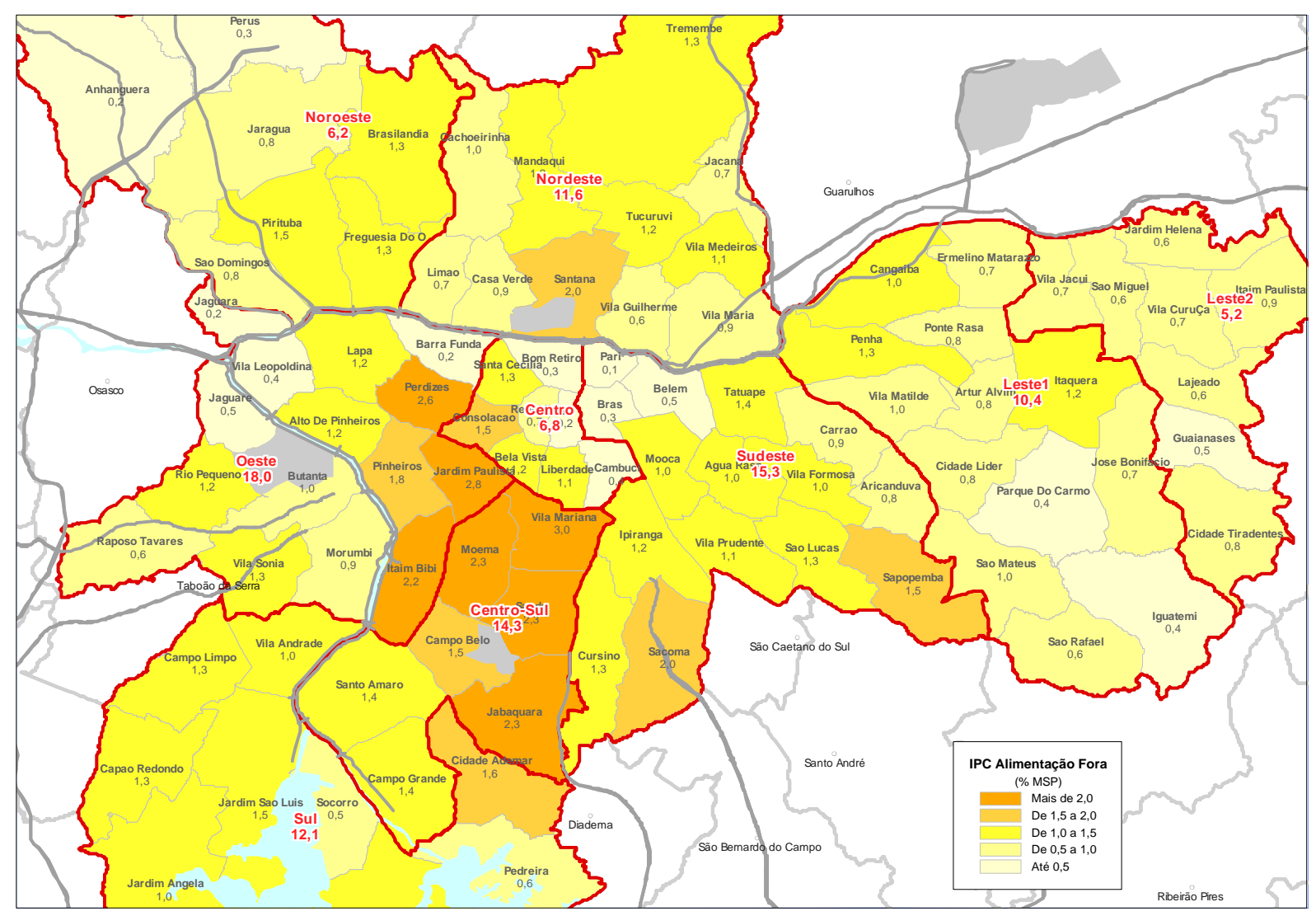

Figura 3: Distribuição do IPC - Alimentação fora do lar por distrito em São Paulo

Fonte: Elaborado pela autora (GEOGRAFIA DE MERCADO, 2010).

Os dados apresentados nesta seção ressaltam a importância do município no contexto nacional, constituindo São Paulo como principal mercado do Brasil, o que pode ser percebido também em uma breve visão de alguns pontos da cadeia alimentar.

\subsection{Visão da cadeia alimentar}

No decorrer do tempo, a cadeia alimentar vem apresentando amplas alterações tanto no que se refere ao modelo de produção como em consequência do processo de industrialização, das mudanças no sistema de distribuição, merecendo ainda destaque o crescimento de serviços de alimentação. 
Sob essa perspectiva, constata-se a relevância de São Paulo nessa cadeia alimentar, decorrente tanto da sua posição de comando no país como da dimensão do mercado que congrega.

\subsubsection{Modelo produtivo}

A produção de alimentos no mundo vem sofrendo profundas transformações desde a década de 1920 e, com maior intensidade, a partir de 1950. Com a evolução tecnológica - impulsionada neste campo principalmente por meio das pesquisas patrocinadas pelos Estados Unidos -, a terra deixou de ser o único fator de produção a ser considerado, de modo que a quantidade produzida não dependesse mais exclusivamente da cultura escolhida, do solo, do clima e da extensão territorial. A indústria de insumos (máquinas, implementos, defensivos, fertilizantes, etc.) também passou a interferir diretamente na capacidade de produção, fazendo emergir um novo modelo produtivo. (COSTA et al., 2010a).

Os impactos dessas profundas mudanças foram sentidos sobretudo depois da Segunda Guerra Mundial, com a chamada Revolução Verde (ZUURBIER, 2000), marcada pelo expressivo aumento da oferta de alimentos e o enraizamento de uma cultura da busca continuada por novas ferramentas que maximizassem a produção (COSTA et al., 2010a, p.14).

No Brasil, a vasta extensão territorial retardou a adoção desses procedimentos em relação a outros países (FAO, 2010; COSTA et al., 2010a)de tal sorte que até meados do terceiro quartil do século $\mathrm{XX}$, as mudanças significativas na produção haviam se dado, especialmente, pela aceitação de novos gêneros e ampliação das áreas cultivadas (FAO, 2010).

As principais mudanças no sentido de tornar o setor agrícola brasileiro mais moderno e desenvolvido se desencadearam somente na década de 1960 através do 
PAEG - Plano de Ação Econômica do Governo 1964-1967 ${ }^{14}$, que tiveram impacto na produtividade a partir da década de 1970 e, principalmente, na segunda metade da década de 1980 (CONSTANTIN, 2007).

Nesse sentido, o IPEA (2010) destacou que houve considerável aumento da produtividade na década de 1990, advinda da mecanização, o que reflete também uma busca deliberada de inserção exportadora (ERNST YOUNG; FGV, 2009).

Mas, além do crescimento da produção e do potencial produtivo, outras mudanças se efetuaram em torno desse novo sistema, como a crescente necessidade de profissionalização das atividades agropecuárias. Essa tendência levou a uma reestruturação dos agentes produtivos, consolidando os "mais eficientes" em direção a uma agricultura de escala e de pressões, em especial, sobre os pequenos produtores (COSTA et al., 2010a, p.14), além de reforçar a lógica da grande propriedade instaurada no Brasil desde o princípio da colonização.

Já no que se refere aos montantes produzidos, é interessante observar que a substituição de um gênero alimentício por outro, destacando-se o aumento do consumo de carne, para citar um deles, também pressiona o crescimento da produção, visto que os animais, para que possam se tornar alimento de humanos precisam antes serem alimentados (FAO, 2010).

Assim, novos desafios se impõem ao desenvolvimento agroalimentar, reforçando a "crescente complexidade" a que se refere Zylbersztajn (2000, p.19), ao caracterizar a produção agrícola.

Corroborando tal ideia, Zuurbier (2000, p.403-404) afirma que "o sistema agroalimentar, antes caracterizado pela autonomia do produtor/consumidor, derivou para uma produção agrícola em maior escala", e hoje se articula como "um sistema interligado com uma grande variedade de relacionamentos complexos".

${ }^{14}$ Reformas macroeconômicas estruturais foram realizadas através do PAEG - Plano de Ação Econômica do Governo (64-67) e produziram, segundo Constantin (2007), "quatro mecanismos de mudanças no setor agrícola que amadureceram principalmente no período do milagre econômico brasileiro (1967-1973)", a saber: internalização dos setores de bens de capital e insumos; crédito rural subsidiado; processo de reestruturação industrial da agroindústria no Brasil (movimento que promoveu mudanças organizacionais e a segmentação de mercados e produtos); e transformação do varejo que desencadeou nos grandes centros urbanos uma forte expansão dos super e hipermercados. 
Ainda sob essa ótica apontam Santos e Silveira (2003, p.143) para uma "crescente segmentação territorial das etapas do trabalho, intensificando-se as trocas e relações entre as regiões", dentro da lógica de reestruturação do território abordada no capítulo anterior. Eles destacam que uma área, conforme o modelo da agricultura moderna, pode praticamente não se relacionar com uma localidade que Ihe é vizinha, e manter estreitas relações com uma cidade de outro país. Desse modo, emergem "circuitos espaciais de produção" em substituição aos "circuitos regionais de produção" (SANTOS; SILVEIRA, 2003, p.143).

Em uma cidade como São Paulo, basicamente urbana, confronta-se claramente a desvinculação territorial entre produção e comercialização. Apesar de praticamente não produzir matérias-primas ou insumos alimentares (PROJETO LUPA, 2010), São Paulo desempenha um importante papel no atual sistema alimentar, como polo econômico de desenvolvimento tecnológico, de transformação, estocagem e comercialização.

Segundo o Conselho Nacional de Pecuária de Corte (2010), o Brasil detém o segundo maior rebanho bovino do mundo, contando com cerca de 200 milhões de cabeças, em 2010. Vale ressaltar que em São Paulo não se vê um boi, mas aí são tomadas as decisões sobre preço da arroba do boi e de tantas outras commodities que são operadas na Bolsa, e que, consequentemente, acabam por impactar na produção e oferta dos bens.

Desse modo, o papel da capital paulistana no sistema agroalimentar, segundo Santos e Silveira (2003), está ligado a uma hierarquização dos lugares, como decorrência das sucessivas divisões do trabalho que acontecem em cada lugar ao longo do tempo, distinguindo-se, pois, como o principal posto de comando do Brasil.

\subsubsection{Indústria}

O crescimento da indústria de alimentos tem expressivo impacto no mercado de alimentação, com produtos processados que substituem gêneros in natura. Embora na atualidade São Paulo não tenha tanta representatividade dentro 
da indústria nacional de alimentação, deve-se salientar sua importância na consolidação desta e como sede administrativa de diversas empresas.

Fazendo uma retrospectiva do processo de industrialização, deve-se notar que a cidade de São Paulo começou a prosperar com a expansão do café para o oeste paulista, sendo determinante ponto de intermediação, mas é o setor industrial que se constitui como notável propulsor da cidade, atraindo expressivo contingente de mão de obra e colocando-a num outro patamar econômico dentro do país (CAMPOS FILHO, 2001).

A industrialização, no início, ocorreu como atividade secundária sob a ótica de grupos ligados à exportação (VERSIANI E VERSIANI, 1975; CAMPOS FILHO, 2001) e deve ser entendida, especialmente em São Paulo, relacionada à crise do café ${ }^{15}$.

Assim, a indústria brasileira começou a se consolidar de fato na década de 1930, incentivada pelo declínio na capacidade de importação decorrente da depressão econômica (FURTADO, 2006). No entanto, antes disso já havia indícios de industrialização no país, especialmente no ramo têxtil e de alimentos (que se mantiveram, nessa ordem, como as duas mais importantes indústrias do país até o início da década de 1950).

Embora a indústria de alimentos continuasse crescendo, à medida que a industrialização se aprofundava, o seu peso relativo diminuiu por certo período (BIRCHAL, 2004). Entretanto, com a abertura econômica durante o governo Collor, esse setor recebeu vultosos investimentos internacionais e voltou a participar amplamente na produção industrial (BAER, 2002).

Deve-se atentar também, paralelamente ao crescimento dessa indústria, para as significativas mudanças na estrutura desse mercado, a partir da última

\footnotetext{
${ }^{15}$ Desde o final do século XIX, o país enfrentava crises por causa da superprodução de café, as quais os influentes cafeicultores tentavam contornar com o apoio do governo. No entanto, a política de defesa do café criou uma situação insustentável com estoques que se avolumavam sem a expectativa de serem colocados no mercado, e uma oferta que não parava de crescer estimulada por uma falsa rentabilidade do produto (FURTADO, 2006). É nesse contexto que a indústria se constitui como excelente oportunidade de investimento, tirando a cidade das sombras da civilização rural em que se encontrava até o final do século XIX (HOLANDA, 2010).
} 
década do século $X X$. Até esse período, a indústria de alimentos se mantinha pulverizada, sendo constituída por empresas pequenas (em relação à média dos demais ramos industriais), na sua maioria de capital nacional. Porém, com a entrada maciça de capital estrangeiro, deu-se a concentração do setor, e este passou a ser controlado majoritariamente por multinacionais (BIRCHAL, 2004).

Concomitantemente, consolidam-se alguns gigantes brasileiros, tais como a JBS (que, em 2009, adquiriu a Bertin e se tornou a maior processadora de proteína animal no mundo) e a BRF - Brasil Foods (junção da Perdigão e da Sadia, com presença expressiva no mercado de aves e suínos), cuja participação se destaca no mercado internacional.

Dados da ABIA - Associação Brasileira das Indústrias da Alimentação referente ao exercício de 2009 indicam que o faturamento da indústria alimentícia atingiu 247 bilhões e o de bebidas, 45 bilhões (ABIA apud SANTOMAURO, 2011).

Dentre os setores da indústria alimentícia com maior participação sobressai o de "derivados da carne" com 24\%, como aponta a Tabela 12. Nesse setor, conforme Jumari Soares Machado, diretor da ABIPECS - Associação Brasileira da Indústria Produtora e Exportadora de Carne Suína, tanto a carne de frango quanto a suína têm ganhado espaço em relação à bovina, pois são mais baratas (MACHADO apud SANTOMAURO, 2011).

A expectativa para os próximos anos é de que o consumo de gêneros processados continue crescendo e a um ritmo mais acelerado do que o consumo de gêneros in natura (ERNST YOUNG; FGV, 2009). 
Tabela 12: Distribuição da produção industrial (2009)

\begin{tabular}{|c|c|c|}
\hline Produtos & $\begin{array}{l}\text { Participação \% } \\
\text { no faturamento }\end{array}$ & $\begin{array}{c}\text { Variação \% } \\
(2009 \text { x 2008) }\end{array}$ \\
\hline Derivados da carne & 23,7 & $-4,1$ \\
\hline Café, chá e cereais & 13,3 & 5,9 \\
\hline Açúcares & 12,3 & 90,7 \\
\hline Laticínios & 11,8 & 10,2 \\
\hline Óleos e gorduras & 11,8 & $-9,4$ \\
\hline Derivados de trigo & 7,7 & 1,2 \\
\hline Derivados de frutas e vegetais & 6,0 & 1,0 \\
\hline Diversos (sorvetes, snacks, temperos) & 6,2 & 9,4 \\
\hline Chocolate, cacau e balas & 4,0 & 8,7 \\
\hline Desidratados e supergelados & 2,3 & 9,3 \\
\hline Conservas de pescados & 9,0 & 13,6 \\
\hline
\end{tabular}

Fonte: ABIA (apud SANTOMAURO 2011, p. 80).

Porém, é importante observar que não é apenas a indústria de alimentos que exerce influencia sobre o mercado de alimentação. Nesse sentido, devem ser ressaltados outros impactos da industrialização, como: a considerável transformação que representam os meios de conservação de alimentos, a exemplo dos refrigeradores e congeladores; a mudança nos procedimentos (e até mesmo na estrutura física), com a incorporação dos diversos equipamentos de cozinha; ou até mesmo a ampliação de possibilidades que passou a compor o sistema logístico, incluindo o transporte aéreo no âmbito das transações de itens mais perecíveis. Ou seja, os impactos da industrialização na oferta de alimentos podem ser percebidos muito além do segmento específico.

\subsubsection{Distribuição}

A despeito de qualquer tradição cultural, o acesso da população em geral a ingredientes e produtos é um elemento determinante para o desenvolvimento da culinária e da oferta gastronômica de uma sociedade. Sob esse prisma, questões como armazenagem e distribuição alcançam posição de destaque nas reflexões que se desenvolvem acerca desses temas. 
O primeiro marco que repercutiu no sentido da centralização do abastecimento em São Paulo, segundo Silva (2008, p.44), remonta ao século XIX, época em que a Câmara Municipal "adquire uma maior autonomia em um processo onde a própria cidade passa a definir melhor a idéia de urbano", e corresponde à criação do mercado das casinhas, em 1773, o primeiro mercado da cidade, no denominado triângulo. Com o intuito de abrigar a venda de gêneros como milho, arroz, feijão, farinha e toucinho, que constituíam a base da alimentação paulistana nos diversos estratos sociais, o mercado das casinhas, porém, não foi suficiente para suprir as necessidades da população da época, sendo a comercialização realizada também em outros pontos - de maneira formal e informal nos anos seguintes.

Responsável pela fixação dos preços e pela regulamentação do comércio, as ações da Câmara no século XIX foram marcadas pela ideia de separação entre o urbano e o rural, de tal modo que as discussões sobre serviços de abastecimento e venda de gêneros alimentícios se inseriam nesse contexto de definição e maior controle das atividades urbanas e de ordenação da cidade. Assim, se proibiu a criação de animais soltos na cidade e se instaurou uma política de impostos guiada pelo tipo de estabelecimento e pelo local de atuação na cidade, pela qual aqueles que estavam no centro urbano pagavam mais do que os que estavam fora dos limites das pontes ou em outras freguesias do município. As únicas exceções foram os tabuleiros/ quitandas, que pagavam o mesmo valor para atuar em qualquer local, um valor que soava alto quando comparado aos estabelecimentos como tabernas, e demonstra ser uma política de desincentivo ao comércio não edificado - contra o qual se impunham também os comerciantes (SILVA, 2008).

Ainda que a definição do que pudesse ser vendido em cada tipo de comércio não fosse clara, é possível perceber que itens complementares à dieta, como frutas, legumes e verduras (além de peixes pescados nos rios que cortam a cidade), e gêneros prontos para consumo - quitutes, petiscos, guloseimas, eram, sobretudo, domínio das quitandeiras (SILVA, 2008).

O tráfego pela cidade, contudo, não era livre, havendo pontos destinados ao estabelecimento das quitandeiras, muito embora por vezes elas se deslocassem por outras áreas, burlando a fiscalização. Mesmo que houvesse dificuldade em delimitar espaços de atuação das quitandeiras, a existência de claras entradas da 
cidade, marcadas pelas pontes (que funcionavam como pontos de vigilância e cobrança de impostos), facilitava o controle do abastecimento no núcleo urbano, onde havia maior fiscalização. Então, era no entorno a maior dificuldade de se controlar o comércio e a ação de atravessadores, que acabavam por causar problemas de desabastecimento e aumentos dos preços na cidade. Por conseguinte, com o crescimento da cidade e a expansão dos seus limites, as dificuldades de controle eram crescentes (SILVA, 2008).

O final do século XIX abriga a transferência do mercado das casinhas, com a inclusão de uma ala para peixes marítimos vindos de Santos e a abertura de um mercado acessório, dedicado ao comércio de gêneros até então comercializados pelas quitandeiras (SILVA, 2008).

Já o início do século XX é marcado pela disseminação das primeiras feiras livres (cuja origem remonta aos mercados caipiras localizados fora dos limites da cidade), que foram oficializadas em 1914 (ZAMONER, 2002), pela inauguração do atual mercado central, em 1933, e ainda pela multiplicação dos mercados públicos na cidade (como os mercados da Lapa, de Pinheiros, de Santo Amaro, da Penha, entre outros, boa parte dos quais resiste até hoje), como respostas às necessidades do município de ampliar e descentralizar o comércio de gêneros alimentícios (PREFEITURA DE SÃO PAULO, 2010c).

Com o crescimento da população, a complexidade do abastecimento alimentar na cidade se intensificou. Se até então a principal preocupação se centrava no mercado de varejo, a necessidade de estruturar o atacado se tornou premente. Assim, vão se fortalecendo na cidade duas redes de distribuição complementares, a atacadista e a varejista.

É nesse contexto de estruturação do sistema que são criados a CAGESP Companhia de Armazéns Gerais do Estado de São Paulo (1930); a CFP Companhia de Financiamento da Produção (1943); e o Ceasa - Centro Estadual de Abastecimento (1960).

Nos grandes centros urbanos do mundo, os alimentos costumam passar por plataformas centrais de distribuição atacadista, cujo principal papel é centralizar os produtos para que os agentes varejistas se abasteçam. No Brasil, quem exerceu tal função inicialmente foram as centrais públicas, sendo atualmente a CEAGESP - 
Companhia de Entrepostos e Armazéns Gerais de São Paulo, a responsável pelo abastecimento da cidade de São Paulo e grande ícone nacional (ZYLBERSZTAJN, 2000).

Criada em 1969 a partir da fusão do e da CAGESP, a CEAGESP é, ainda hoje, o maior entreposto de comércio atacadista da América do Sul.

Do ponto de vista da comercialização, a CEAGESP, no bairro da Vila Leopoldina, é responsável por $60 \%$ do abastecimento da Grande São Paulo e municípios vizinhos. Ali são comercializadas cerca de 240 mil toneladas/mês, sendo movimentados, em média, $\mathrm{R} \$ 15$ milhões por dia (CEAGESP, 2010a).

São mais de 1500 variedades de itens comercializados, entre frutas, legumes, verduras, pescados e flores, representando a maior diversidade de ingredientes disponível no Brasil. Aproximadamente, 90\% dos produtos são produzidos no país, sendo 55\% no próprio estado de São Paulo. Já entre os itens que vêm de fora do país, a liderança é da Argentina com cerca de $3 \%$ do volume total (CEAGESP, 2010b).

A partir da década de 1990, no entanto, a CEAGESP começou a dividir espaço com plataformas de distribuição privadas, que começaram a surgir em sua maioria associadas a redes varejistas de distribuição. Um exemplo interessante nesse sentido é o do distribuidor Benassi, que embora mantenha um box dentro da Ceasa, conta com uma central nas proximidades que se destina a atender clientes como a rede de supermercados Pão de Açúcar (CEAGESP, 2010b). Outro aspecto importante é a segmentação desse mercado, com o surgimento de plataformas e mercados especializados em determinados produtos (ZYLBERSZTAJN, 2000, p.18).

Igualmente relevante é a questão que diz respeito à armazenagem da produção, necessidade imposta pelo acelerado processo de modernização e aumento de produtividade da agricultura. Como resposta, o Brasil ampliou de maneira significativa sua capacidade nesse aspecto, a partir da década de 1980 (o aumento foi de cerca de 1374 vezes entre 1985 e 1995), tendo a rede de armazenagem assumido um papel importantíssimo no tocante ao abastecimento dessa época em diante .(SANTOS; SILVEIRA, 2003, p.148).

Assim, apesar das notáveis transformações pelas quais vem passando 0 setor, a CEAGESP ainda se mantém como o centro atacadista por excelência. Isso 
porque, por meio de algumas medidas como o prolongamento do tempo de estocagem e a emissão de títulos de crédito especiais que possibilitam 0 financiamento dos estoques depositados (warrants), a CEAGESP conseguiu exercer a função de reguladora dos calendários de circulação de mercadorias (CEAGESP, 2010a).

Enquanto a comercialização no atacado chama atenção pelos volumes comercializados, a rede varejista impressiona pela sua amplitude. Nesse sentido poderiam ser destacadas, por exemplo, as feiras livres que acompanharam a expansão urbana e se distribuem por toda a cidade, havendo em São Paulo 850 delas que congregam atualmente 43.750 bancas, isto é, o equivalente a 1 banca para cada 250 habitantes, conforme pode ser observado na Figura 4 (PREFEITURA DE SÃO PAULO, 2010a).

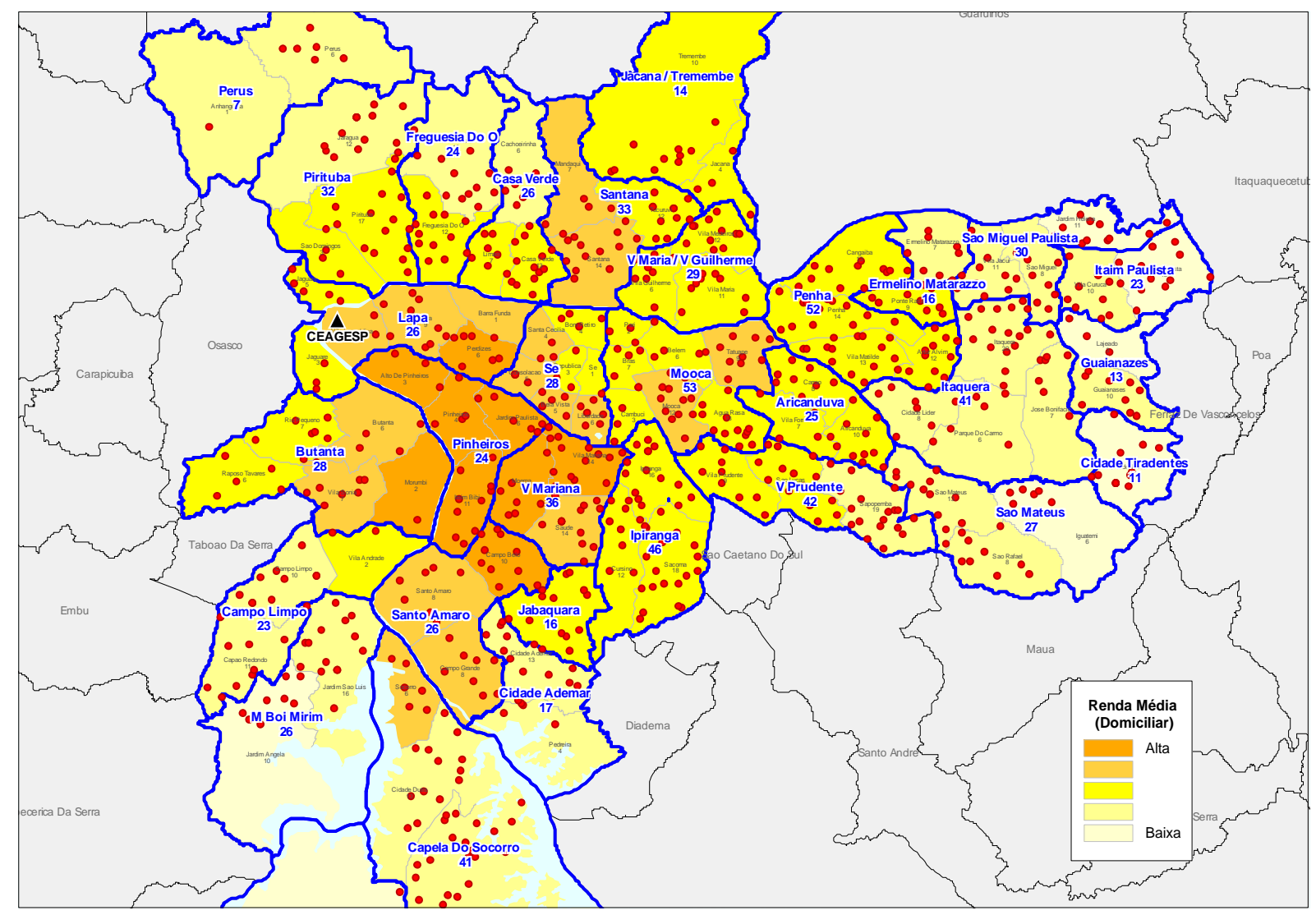

Figura 4: Feiras por distritos e subprefeituras no Município de São Paulo

Fonte: Elaborado pela autora (PREFEITURA DE SÃO PAULO, 2010a). 
Entretanto, assim como outras formas de comércio tradicional e de rua, elas tiveram sua importância comercial reduzida, por causa da expansão dos supermercados que, de acordo com Valdir Orsetti, diretor da revista Supermercado Moderno canalizam hoje mais de $75 \%$ da distribuição de alimentos no Brasil $^{16}$.

O primeiro estabelecimento do gênero supermercado no Brasil surgiu em 1953, na cidade de São Paulo, o "Supermercado Americano S.A.". (STILMAN, 1962). De acordo com a revista Supermercado Moderno, em 1960, eram computados cerca de 800 supermercados no Brasil (SUPERMERCADO MODERNO, 1983).

Já em 2009, segundo a revista SuperHiper, da Associação Brasileira de Supermercados (ABRAS), o setor de autosserviço, no Brasil, contava com 78 mil lojas e atingiu o faturamento recorde de $R \$ 177$ bilhões. Somando 192 mil checkouts, 900 mil empregos diretos, atingiu participação de 5,6\% no PIB brasileiro (ABRAS, 2010).

Vale ressaltar que as três maiores cadeias (Companhia Brasileira de Distribuição, Carrefour e WalMart) representam 40\% do faturamento do setor, e não por acaso possuem sede na cidade de São Paulo, onde também concentram parcelas expressivas das suas lojas (ABRAS, 2010).

Segundo dados obtidos por meio do Geoconnection (NILSEN; GEOGRAFIA DE MERCADO, 2010), a cidade de São Paulo possuía 20.876 lojas alimentares em 2009. Dessas, 13.020 eram consideradas tradicionais (empórios, armazéns, ...), 4.463 eram padarias e 3.393 , super/hipermercados.

Desse total de super/hipermercados, apenas 8,3\% deles, isto é, 282 , contavam com 10 ou mais checkouts, porém, representavam 62,5\% do volume negocial das lojas de alimentação. Aqueles com menos de 10 checkouts representavam $23 \%$ e determinavam mais de $85 \%$ do faturamento geral das lojas de alimentos em São Paulo.

${ }^{16}$ Informação colhida através de entrevista concedida por telefone em Janeiro de 2011. 
Deve-se notar que, tão importante quanto o expressivo crescimento dos supermercados no país é a mudança de hábito de consumo que ele representa, sobretudo pela introdução de grandes quantidades de produtos industrializados e semiprontos.

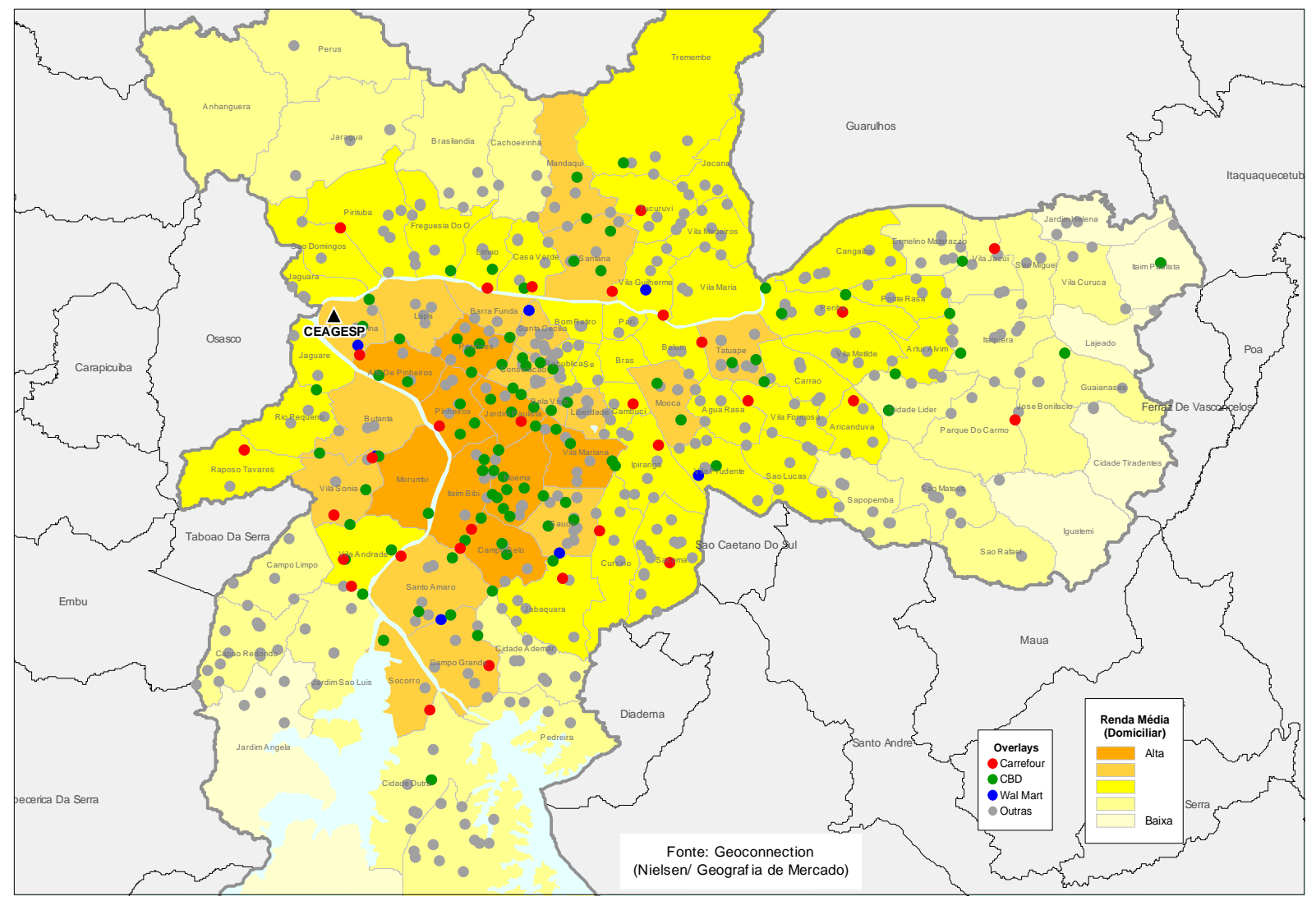

Figura 5: Super/Hipermercados por principais redes em São Paulo

Fonte: GEOGRAFIA DE MERCADO (2010).

Nesse cenário, Cunha e Machado (2003, p.12) apontam no sentido de uma homogeneização da oferta pela dominação de algumas redes, destacando-se que, em virtude da facilidade que representam as compras centralizadas em um único lugar, gêneros produzidos em locais próximos das lojas podem ficar de fora das prateleiras.

Emerge também uma preocupação no que se refere à relação estabelecida entre esses grandes conglomerados e produtores, especialmente os de pequeno porte. 
Os supermercados são, como comentam Santos e Silveira (2003, p. 150) "elos fundamentais nas cadeias de distribuição e produção, pois participam das diversas instâncias, criando marcas, agindo como oligopólios em algumas produções, modificando o calendário de pagamentos." Comandam, assim, uma importante parcela do comércio varejista. Por seu contato direto com os consumidores é grande o seu poder de coordenação do sistema agroalimentar, seja pelo poder de barganha com fornecedores ou acesso privilegiado aos dados sobre preferências e hábitos dos consumidores. Mais do que um ponto de comercialização, os supermercados tornam-se gestores dos espaços de prateleiras, sendo estas o elo de contato entre consumidores e produtores (ZYLBERSZTAJN, 2000, p.17).

É nesse contexto que aqueles mercados públicos criados na metade do século $X X$ vão tendo sua função parcialmente transformada. Se por um lado estes espaços passam a responder apenas parcialmente pelas necessidades de consumo dos habitantes da cidade, por outro, seus comerciantes procuram buscar alternativas e agregar valor à sua oferta; oferecem, por exemplo, carnes de caça, coelhos e cabritos frescos, menos comuns de serem encontrados em supermercados da cidade. Ademais, em alguns casos, como o do Mercado Central de São Paulo - na Rua da Cantareira, pode-se perceber a aproximação entre consumo e lazer, tendo em vista que o mercado passou a assumir também o papel de atrativo turístico depois da sua restauração em 2004 com a implantação de bares e restaurantes.

Fundamental destacar também a crescente importância dos setores de comércio e serviços, dentre estes, aqueles segmentos referentes à alimentação fora do lar, em São Paulo, a partir da segunda metade do século XX. Esse cenário contribuiu não somente para uma mudança no mercado paulistano, mas também brasileiro.

Uma visão integrada da cadeia alimentar no Brasil, partindo da produção de alimentos, passando pela indústria de transformação, canais de distribuição, entre eles, o food-service ${ }^{17}$, é apresentada na Figura 6.

\footnotetext{
${ }^{17}$ Food service corresponde a serviços de alimentação - canais que distribuem produtos ou preparam refeições para o consumo fora do lar (ABIA, 2010). Pode ser dividido em diferentes segmentos, englobando os canais comerciais - aqueles em que a alimentação é um serviço e uma fonte de receita (principal ou adicional), como os restaurantes, lanchonetes, padarias, rotisserias, lojas de conveniência, academias, entre outros; e os sociais - aqueles em que a alimentação é um serviço que não visa ao lucro, como presídios, escolas públicas (merenda escolar) e hospitais (ECD, 2010).
} 


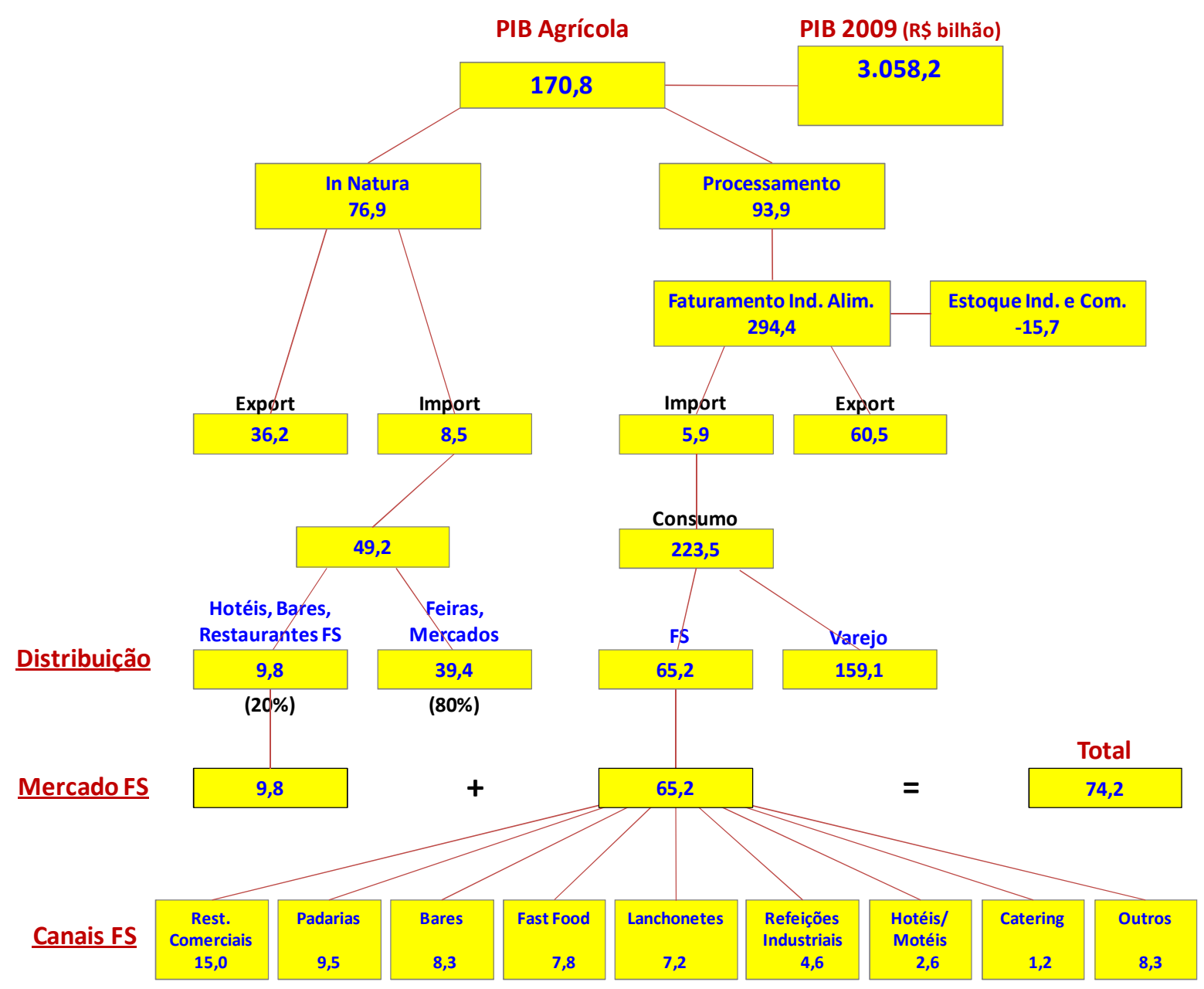

Figura 6: Fluxograma da distribuição de alimentos - 2009

Fonte: Adaptado de ABIA, 2010, p.34; p37.

O valor de faturamento da indústria alimentícia atingiu $R \$ 294$ bilhões e teve como origem de matérias-primas $\mathrm{R} \$ 94$ bilhões (maior do que o consumo in natura, que atingiu $R \$ 77$ bilhões), isto é, a indústria tem um fator multiplicador superior a três.

Vale ainda destacar que a Grande São Paulo é responsável por $18 \%$ do valor e do volume de vendas da produção industrial de alimentos e que o interior do Estado é responsável por mais $9 \%$ do valor das vendas, de modo que o Estado de São Paulo representa mais de um quarto do mercado brasileiro (ABIA, 2010).

Outro fato notável é que o crescimento das vendas para o mercado de Food Service vem superando o crescimento das vendas para o varejo, como reflexo de uma maior participação das refeições fora do domicílio (ABIA, 2010). 
Nesse sentido, pode-se evidenciar que, enquanto o food service apresentou crescimento médio nominal de $15,4 \%$ entre 2002 e 2009 , o varejo cresceu $8,6 \%$, ou seja, o food service apresentou quase o dobro do crescimento do varejo nesse período, o que pode ser observado no Gráfico 5.

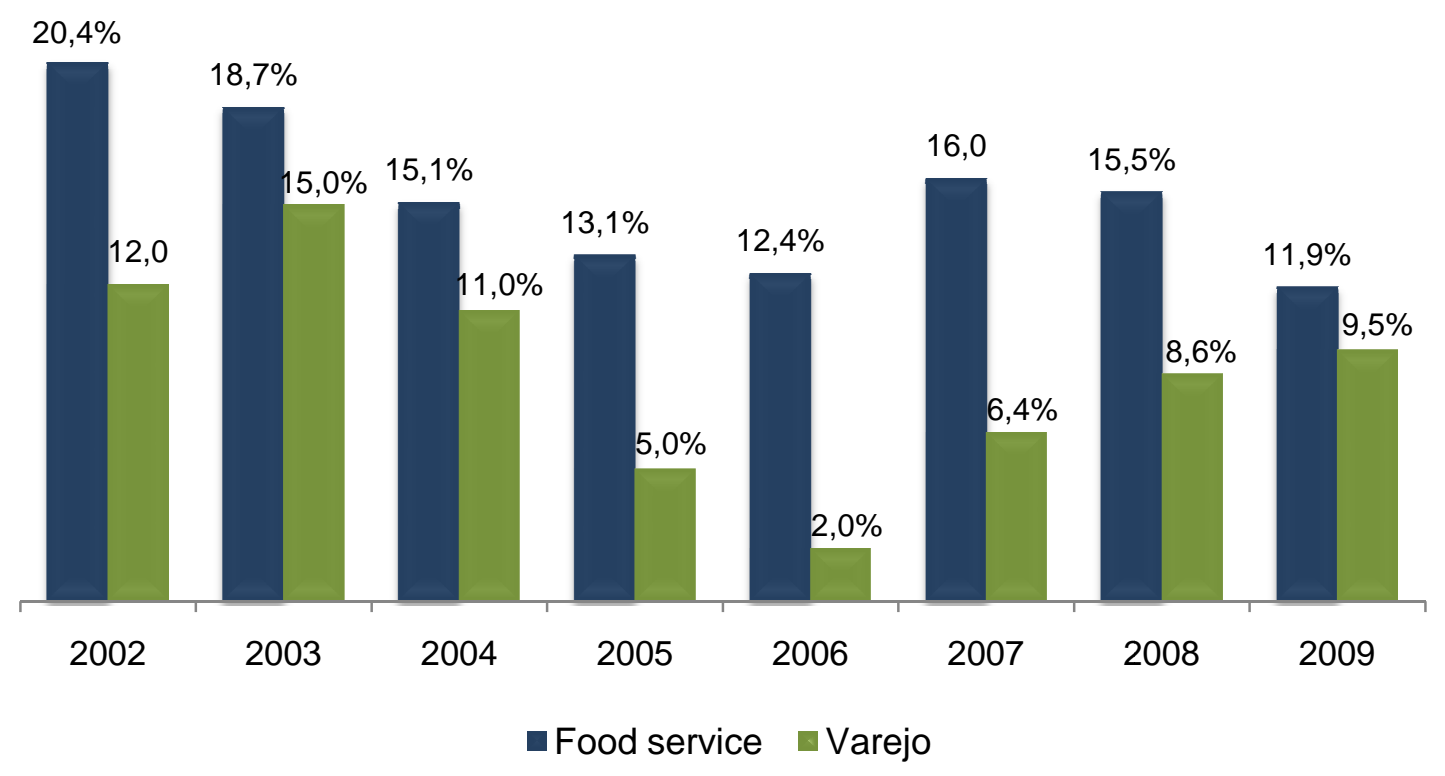

Gráfico 5: Crescimento anual do food service e do varejo (2000 - 2009)

Fonte: Adaptado de Donna, 2010.

Pode-se assinalar ainda que o faturamento desse mercado, em 2009, atingiu $\mathrm{R} \$ 180$ bilhões, sendo contabilizadas 60 milhões de refeições por dia (ECD, 2010).

Dentre os canais do food service, merecem especial realce os restaurantes (dos quais se tratará mais adiante), responsáveis por cerca de um quarto do faturamento do segmento, conforme ilustra o Gráfico 6. 


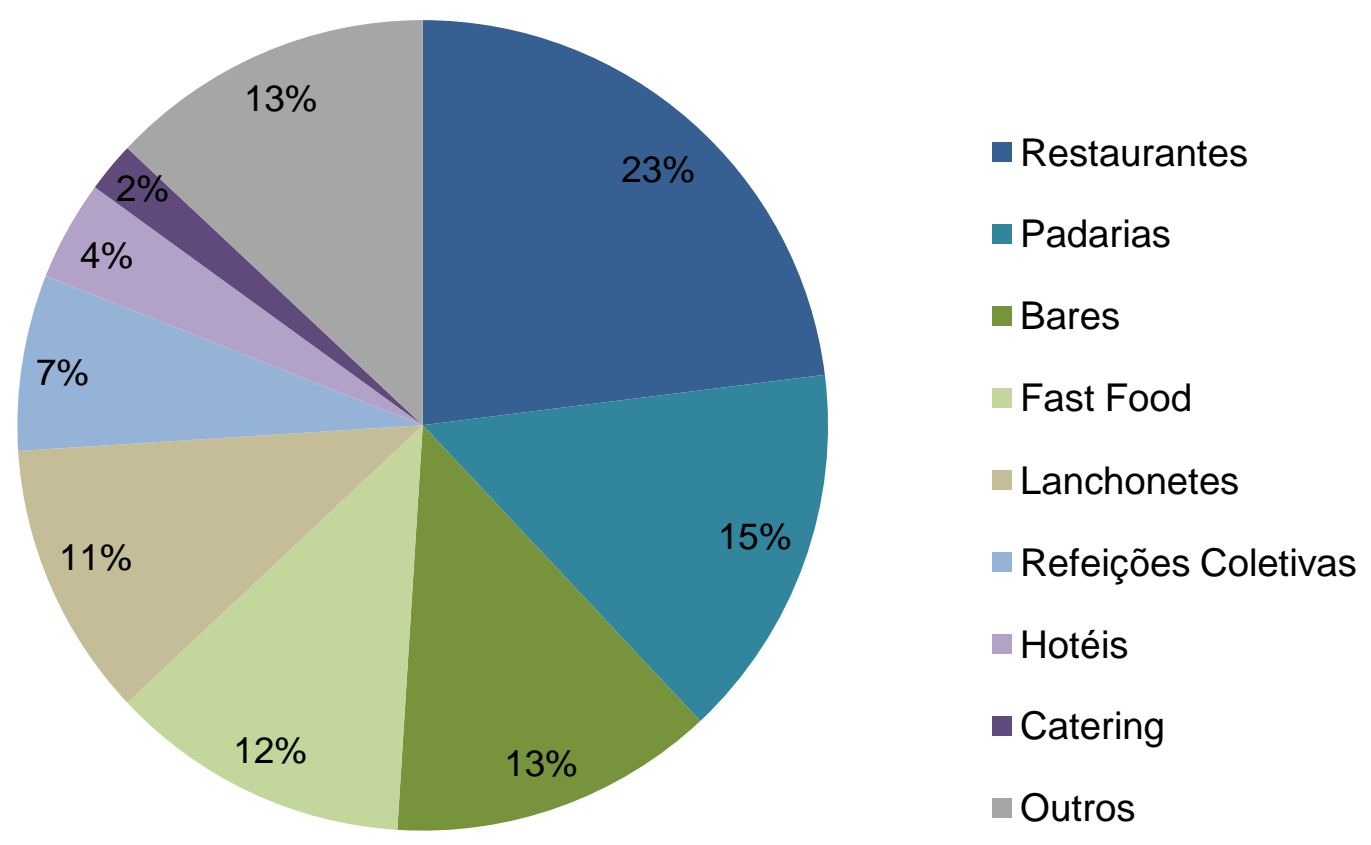

Gráfico 6: Dimensionamento do mercado de food service

Fonte: Donna, 2010.

Oferecendo-se a dimensão desse mercado, vale ressaltar que somente a cidade de São Paulo conta hoje com cerca de 12,5 mil restaurantes com características distintas (ABRASEL, 2009), alguns deles, inclusive, reconhecidos internacionalmente, os quais ajudam a consolidar uma imagem de São Paulo como polo gastronômico.

\subsection{Variáveis impactantes no consumo de alimentos}

Acompanhar algumas mudanças que vêm acontecendo na cidade de São Paulo auxilia na compreensão do dinamismo da mesa paulistana. Para a eleição das variáveis a serem assinaladas, pautou-se no estudo realizado pelo Instituto de Tecnologia de Alimentos (ITAL) - ligado à Secretaria de Abastecimento do Estado de São Paulo, em parceria com a Federação das Indústrias do Estado de São Paulo 
(FIESP), intitulado "Brasil Food Trends 2020", que visou apontar tendências no mercado de alimentação brasileiro (ITAL; FIESP, 2010).

\subsubsection{Crescimento populacional}

É importante observar que não só o Brasil, mas também a cidade de São Paulo, principalmente, assistiram a um significativo salto demográfico desde o final do período colonial até os dias atuais. Segundo Matos (apud OLIVEIRA, 2010), a cidade registrava cerca de 20 mil habitantes em 1810, em 1900 já eram quase 240 mil e, em 2010, ultrapassou os 11 milhões. Já para o Brasil, os números atingiram 4 milhões (1810), 17 milhões (1900) e 191 milhões (2010).

Tabela 13: Evolução da População - Brasil e São Paulo (1872 - 2010)

\begin{tabular}{|rrrr|}
\hline Ano & Brasil & São Paulo & $\%$ \\
\hline 1872 & 10.112 .061 & 31.385 & 0,3 \\
1890 & 14.333 .915 & 64.934 & 0,5 \\
1900 & 17.318 .556 & 239.820 & 1,4 \\
1920 & 30.635 .605 & 579.033 & 1,9 \\
1940 & 41.236 .315 & 1.326 .261 & 3,2 \\
1950 & 51.944 .397 & 2.198 .096 & 4,2 \\
1960 & 70.119 .071 & 3.781 .446 & 5,4 \\
1970 & 93.139 .037 & 5.924 .615 & 6,4 \\
1980 & 119.002 .706 & 8.493 .226 & 7,1 \\
1991 & 146.825 .475 & 9.646 .185 & 6,6 \\
2000 & 169.799 .170 & 10.434 .252 & 6,1 \\
2010 & 190.732 .694 & 11.244 .369 & 5,9 \\
\hline
\end{tabular}

Fonte: Adaptado de IBGE, 2010a; Prefeitura de São Paulo, 2010b.

É escusado dizer que o crescimento da população tem impacto quantitativo na demanda por alimentos, cuja procura certamente aumentará para satisfazer as necessidades básicas vitais dos indivíduos. 
Por longos períodos na história, a restrição de alimentos foi um dos principais elementos de constrição do crescimento demográfico e adensamento populacional, assim como uma das principais causas de mortalidade (PERLÉS, 1998). Dessa maneira, apesar de atualmente se considerar que a fome no mundo está vinculada sobretudo à desigualdade e à má distribuição de recursos - visto que são produzidos cerca de três vezes a quantidade de alimentos necessária para alimentar a população do globo (INSTITUTO AKATU, 2010)-, preocupações nesse sentido continuam ocupando posição de destaque nas discussões acerca de alimentação, como aponta o relatório da Organização das Nações Unidas intitulado: "A situação mundial da alimentação e da agricultura - 2009" (FAO, 2010).

Deve-se ter em mente que no atual contexto dos mercados globais, o crescimento da população em outras partes do globo e mudanças nos hábitos alimentares de países como a Índia e a China, que juntos concentram 37\% da população do mundo (ONU, 2009), podem ter bastante impacto nas importações/ exportações mundiais.

A título de exemplo, de acordo com o Departamento de Agricultura dos Estados Unidos (USDA apud COSTA et al., 2010b, p.24), o aumento de consumo anual de um quilo de frango per capita nesses países, por exemplo, representaria um incremento de $30 \%$ nas exportações do produto, valendo ressaltar que o Brasil em 2010 alcançou o posto de maior exportador dessa ave no mundo (LANDIM, 2010).

\subsubsection{Urbanização}

O processo de urbanização, além de refletir mudanças na produção e distribuição de alimentos, exerce ampla influência no seu consumo. De produtores do próprio sustento, a população camponesa passou a compor a economia de mercado, elevando a demanda por alimentos, especialmente os processados e industrializados (COSTA et al., 2010b).

Nesse sentido, pode-se considerar, ainda, que tais alimentos, em conjunto com outros aspectos, acabaram, inclusive, por estimular o processo migratório 
campo-cidade. Segundo Durhan (1973), o modo de viver na cidade pressupõe padrões de consumo como roupas, sapatos e alimentos processados que são percebidos como luxo pelo trabalhador agrícola, já que são inacessíveis aos homens do campo, e fazem com que a cidade seja extremamente valorizada.

Com esse entendimento, o processo de desocupação da área rural foi bastante acelerado de tal modo que o município de São Paulo já se consolidara na economia nacional como sendo majoritariamente urbano, ainda na primeira metade do século $X X$, distanciando-se da realidade da produção agrícola e assumindo posição de controle no atual sistema agroalimentar.

Em 1950, o Brasil contava com 52 milhões de habitantes, dos quais mais de 33 milhões moravam em áreas rurais, isto é, 64\%. Em 2010, o país teve o seu contingente populacional praticamente multiplicado por 4 em apenas 60 anos, e manteve na zona rural um número menor de pessoas que o daquela época, isto é, 30 milhões, os quais representavam por volta de $15 \%$ da sua população. Essa transformação rural-urbana foi a maior verificada no mundo ocidental na segunda metade do século passado (IBGE, 1987; 2010a).

Interessante observar também a expansão da área urbanizada do município de São Paulo, na virada para o século $X X$, na sua metade e na passagem para 0 século $\mathrm{XXI}$, respectivamente (Figura 7 ).

É possível verificar a dimensão e o crescimento da cidade, e entrever, também, questões como a ampliação das distâncias entre casa e trabalho, que se deu no decorrer do tempo. Nesse sentido, vale notar que as grandes distâncias a serem percorridas, aliadas a outros fatores como dificuldades de locomoção (a exemplo de um sistema de transportes que não acompanhou o crescimento da cidade), por vezes, inviabilizam, cada vez mais, a volta para casa no horário do almoço, estimulando, assim, o consumo de alimentos fora do lar. 


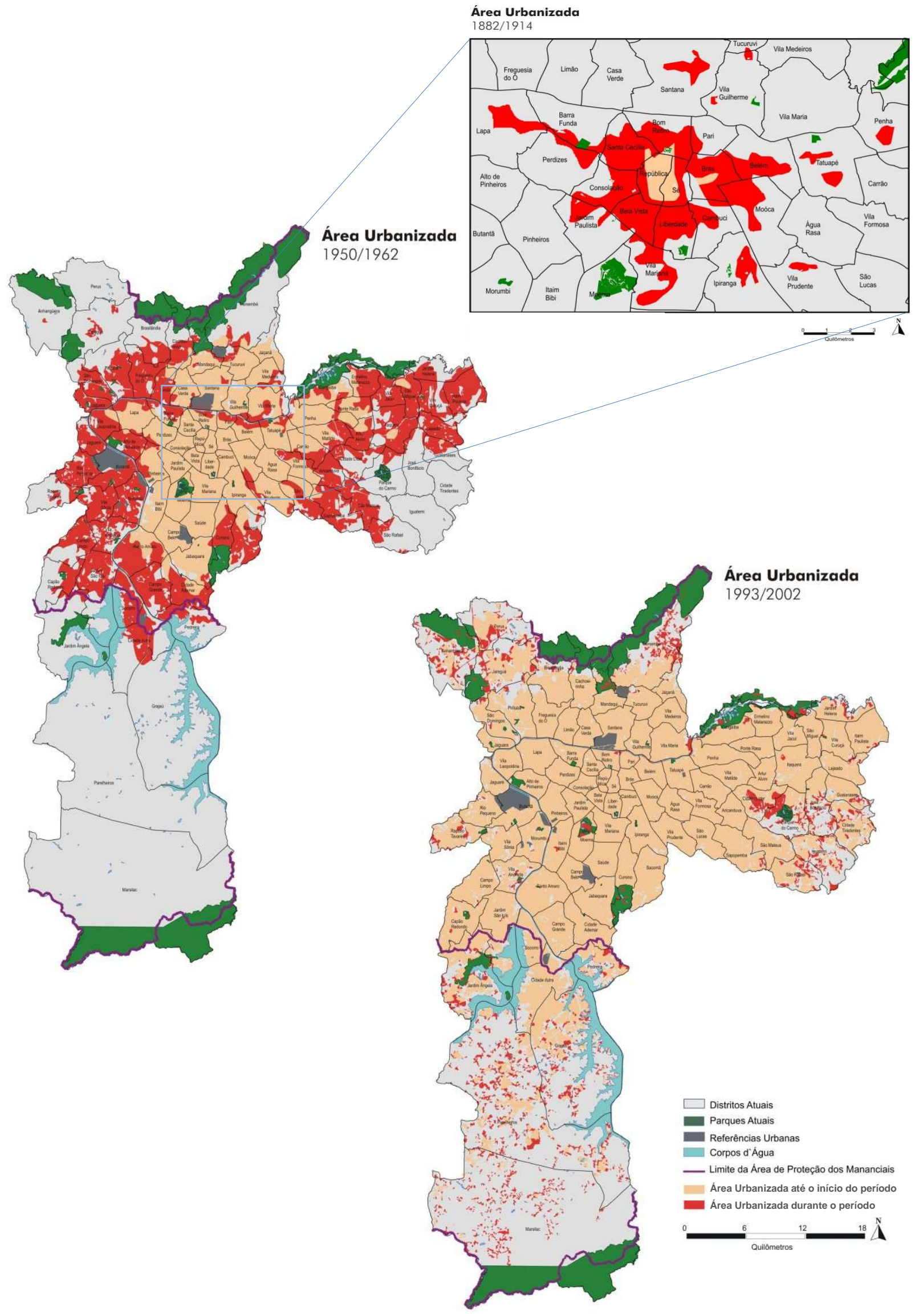

Figura 7: Expansão Urbana em São Paulo

Fonte: Adaptado de Prefeitura de São Paulo, 2010b. 


\subsubsection{Estrutura etária e familiar}

Como resultado da redução da taxa de natalidade conjugada ao aumento da expectativa de vida do brasileiro, o contingente populacional está envelhecendo, o que faz com que também se altere o perfil das necessidades nutricionais e psicossociais dos indivíduos (COSTA et al., 2010b).

Nesse sentido, nota-se que o número de casais sem filhos vem aumentando e que a taxa de fecundidade média no Brasil caiu de 6,15 na primeira metade da década de 1950 (IBGE, 2006) para 1,94 em 2009, estando na faixa de 1,78 no Estado de São Paulo (IBGE, 2010e). Essa redução na taxa de natalidade desacelera o crescimento da população e pode levar até à sua retração, já que o índice de fertilidade média está abaixo do nível de reposição.

Deve-se observar, contudo, que a população não está diminuindo porque as pessoas têm vivido mais. A esperança de vida do brasileiro ao nascer era de 45,5 anos em 1940, passou para 69,7 anos, em 1998, e atingiu os 73,1 anos em 2009, apresentando variação acima da média mundial (ONU, 2009; IBGE, 2010e).

Combinados esses dois fatores, a idade média da população, que era de 20,2 anos em 1980 (IBGE, 2009), cresce, e deve chegar aos 46,2 anos em 2050 (ONU, 2009).

Essas alterações envolvem mudanças quantitativas e, sobretudo qualitativas na demanda por alimentos, pois quando diminui o número de crianças e jovens e aumenta o de adultos e idosos, consequentemente, se alteram tanto os produtos a serem consumidos quanto os locais de frequência a serem valorizados.

\subsubsection{Emprego feminino}

A maior participação da mulher no mercado de trabalho tem impacto especialmente qualitativo na demanda por alimentos. Entre eles, destaca-se o aumento do consumo de itens industrializados e processados, uma vez que ela dispõe de menor tempo para se dedicar ao preparo das refeições, na medida em que acumula uma dupla jornada de afazeres, dentro e fora do lar. 
Desde tempos remotos, o preparo do alimento parece estar ligado, em diversas sociedades, à figura da mulher, como já destacamos no início deste trabalho. Segundo Oliveira (2010), mesmo quando se considera o Brasil escravocrata, em que os escravos assumiram a produção do alimento em si, a Sinhá é que era a responsável pela refeição. O mesmo sucede com as mulheres urbanas nas primeiras décadas do século XX, inclusive as das classes mais abastadas, que, apesar de manterem o empregado doméstico substituindo o escravo no preparo das receitas, assumiam o papel de rainhas do lar, congregando as funções de mãe, esposa e dona de casa (MALUF E MOTT apud OLIVEIRA, 2010, p. 13). Essa relação perdura ainda na atualidade, mesmo depois dos movimentos feministas e da aproximação do homem com o fogão, o que faz com que a mulher moderna, tendo que se dividir cada vez mais entre as tarefas domésticas e o mercado de trabalho, busque, em especial no dia a dia, opções que agilizem o preparo da refeição - como os produtos pré-processados e industrializados, ou até mesmo comidas prontas, entregues em domicílio.

Assim, a falta de tempo para preparar a comida e a busca por maior conveniência levaram a uma redução do tempo no preparo das refeições no Brasil: de 2 horas em 1971 se reduziu para 15 minutos desde o final dos anos de 1990 (IBGE;FIPE apud ALIMENTAÇÃO, 2006).

Vale lembrar que, embora na primeira metade do século $X X$ tivesse havido um recuo da participação feminina no mercado de trabalho, com a substituição de mulheres por homens, sobretudo na indústria têxtil (STEAGALLGOMES; MENDES, 1995), a situação logo se reverteria. Para (OWESNBY, 1999), as crises inflacionárias atravessadas entre as décadas de 1940 e 1950, que ameaçavam o padrão de vida da classe média em formação, acabaram por estimular o trabalho feminino como fonte de renda adicional para a família e, desde então, tal participação não parou mais de crescer, como se pode acompanhar na Tabela 14. 
Tabela 14: Evolução da população economicamente ativa por sexo

\begin{tabular}{|l|c|c|c|c|c|c|c|c|}
\hline Ano & $\mathbf{1 9 4 0}$ & $\mathbf{1 9 5 0}$ & $\mathbf{1 9 6 0}$ & $\mathbf{1 9 7 0}$ & $\mathbf{1 9 8 0}$ & $\mathbf{1 9 9 1}$ & $\mathbf{2 0 0 1}$ & $\mathbf{2 0 0 9}$ \\
\hline Homens (\%) & 81,0 & 85,5 & 82,5 & 79,0 & 73,0 & 64,5 & 58,1 & 56,1 \\
\hline Mulheres (\%) & 19,0 & 14,5 & 17,5 & 21,0 & 27,0 & 35,5 & 41,9 & 43,9 \\
\hline
\end{tabular}

Fonte: Adaptado de IBGE,2010c; IBGE, 1987.

Nota-se que, em pouco mais de quarenta anos, entre 1950 e 1991, a participação feminina mais que dobrou, indo de $14,5 \%$ para $35,5 \%$ na média brasileira, e atingindo 43,9\%, em 2009.

Nas últimas décadas, a presença da mulher no mercado de trabalho em São Paulo tem crescido de forma acelerada. Tendo por referência as estatísticas realizadas pelo MTE - Ministério do Trabalho e Emprego, enquanto em 1985 as mulheres representavam $36 \%$ dos empregos formais, atingiram a expressiva participação de 45\% em 2009 (Gráfico 7).

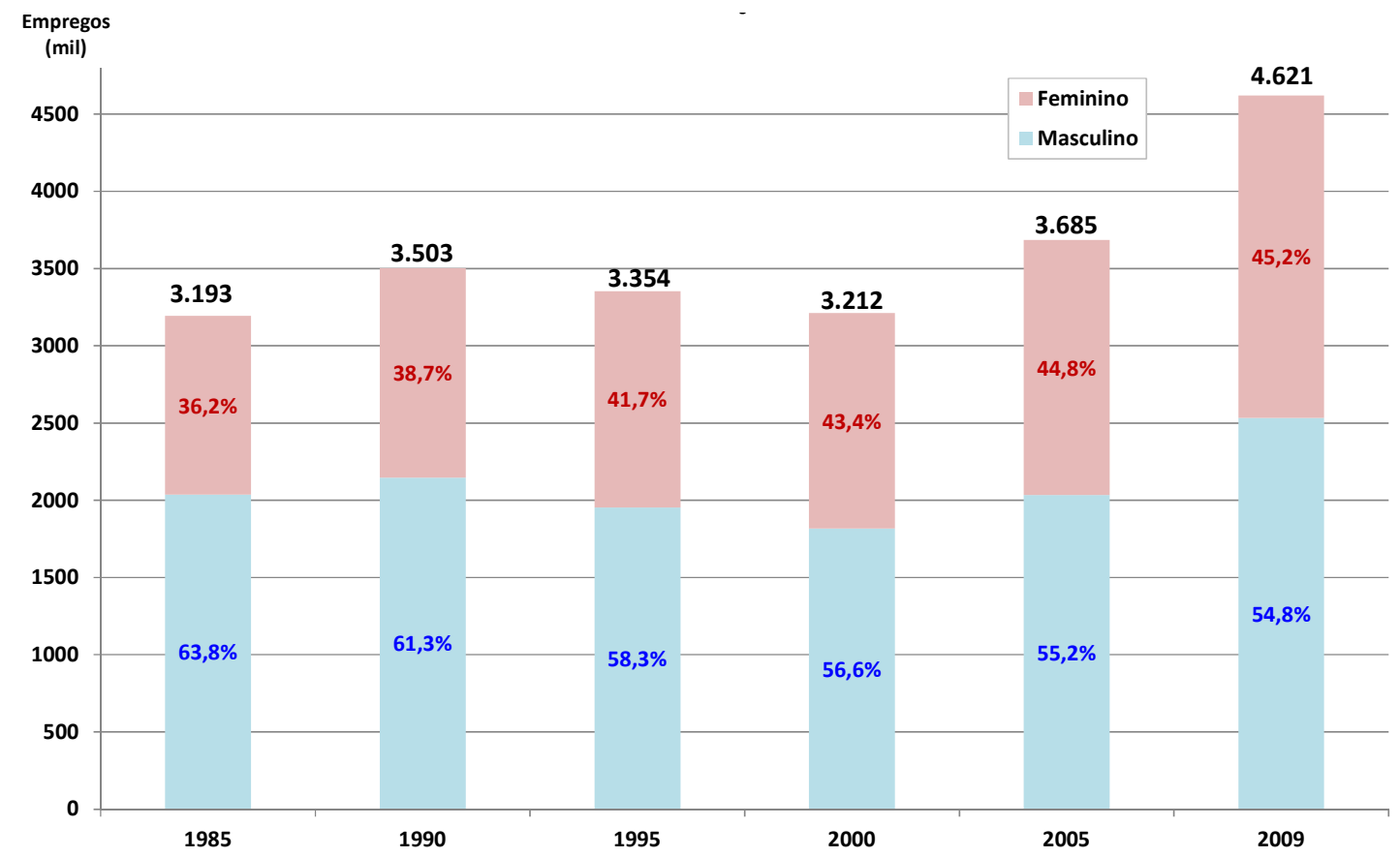

Gráfico 7: Evolução da participação do emprego feminino em São Paulo Fonte: Elaborado pela autora (MINISTÉRIO DO TRABALHO, 2011). 


\subsubsection{Renda}

Outra questão fundamental no que diz respeito a mudanças nos hábitos da alimentação é a renda, cujo aumento amplia quantitativa e qualitativamente as possibilidades de consumo, assunto que será tratado também no item 4.4.3, de maneira comparativa.

Segundo Costa e seus colegas (2010b, p.32):

"No primeiro estágio de acesso à alimentação, a dieta é mais restrita a fontes nutricionais menos custosas, como cereais, açúcar e produtos processados.

A partir de então, alimentos mais complexos passam a ser paulatinamente incorporados, como o leite e seus derivados e carnes de aves, fontes de proteína animal, substituindo parte do consumo daqueles bens básicos. Em sequência, são consumidas outras fontes de proteína animal, como carnes suína e bovina, e incorporam-se produtos hortícolas e frutas. (...) Por fim, chegando a níveis elevados de renda, esse indivíduo passa a considerar atributos além daqueles meramente nutricionais, como sustentabilidade da produção, boas práticas, preservação e respeito ao meio-ambiente, produtos com baixos teores de resíduos, regionalização e origem, etc".

Um marco relativamente recente e bastante significativo na alimentação do brasileiro foi a implementação do Plano Real, em 1994. Com a queda da inflação, a estabilidade dos preços e uma maior oferta de produtos importados (cuja liberação e redução tarifária se dera no governo anterior - Collor) mudaram consideravelmente as cestas de compras dos consumidores em geral, mas foi a camada menos privilegiada que teve maior incremento e acesso a novos itens de consumo.

Sobre esse fenômeno, Silva e Paula (2003, p. 2) relatam:

Um amplo contingente de consumidores foi incorporado ao mercado, ao mesmo tempo em que alguns segmentos da população elevaram seu padrão de consumo, migrando para alimentos mais sofisticados. Assim, há o surgimento de um consumidor mais exigente e atuante, reduzindo o abismo que nos separa dos países mais desenvolvidos. 
Prova da alteração de comportamento do consumidor, em decorrência do novo cenário econômico, é que, em 1994, primeiro ano da vigência do Plano Real, produtos da cesta básica como café, cereais, açúcar e sal tiveram queda nas vendas em $6 \%$, enquanto biscoitos, chocolates, sucos e derivados lácteos tiveram aumento (JUNQUEIRA apud SILVA; PAULA, 2003, p.7).

Para os próximos anos, a expectativa é de que o consumo de alimentos no Brasil acompanhe de perto o crescimento da renda. A previsão é que a renda cresça $3,1 \%$ anualmente até 2030 e que o consumo de alimentos cresça $3 \%$ ao ano nesse período, esperando-se um crescimento de 2,5\% para produtos in natura e 3,1\% para produtos processados (ERNST YOUNG; FGV, 2009).

\subsubsection{Educação e informação}

Educação e informação influenciam o consumo de alimentos, sobretudo no aspecto qualitativo. No âmbito da educação formal, os reflexos no consumo de alimentos na cidade podem ser percebidos de diferentes formas. Merecem ser citados como exemplo os impactos que a fundação da Faculdade de Direito do Largo de São Francisco, em 1827, causou em São Paulo. O primeiro curso de Direito do país atraiu para a cidade um público não só da própria cidade como de outras regiões, criando, assim, uma demanda por pensões estudantis e, por conseguinte, refeições dentro, mas também fora delas, isto é, nas ruas.

Em épocas mais recentes, o principal impacto decorre de uma maior exigência por parte desses consumidores. $O$ consumidor com mais anos de estudos, além de ter maior renda, é mais bem informado e mais exigente, dando preferência, por exemplo, aos produtos que privilegiem a sua saúde (COSTA et al, 2010). Nesse sentido, Aranceta e seus colegas (apud ESTIMA; PHILIPP; ALVARENGA; 2009, p.264) afirmam que famílias que têm menor nível socioeconômico e cujas mães apresentam baixo nível de escolaridade consomem proporcionalmente mais doces e produtos ricos em gordura (ARANCETA et al. apud ESTIMA; PHILIPP; ALVARENGA; 2009, p.264). 
A despeito de o brasileiro apresentar, na média, baixo nível de escolaridade, os índices, quando considerados os anos de estudo, vêm apresentando crescimento (Gráfico 8), o que configura uma expectativa de aumento das exigências dos consumidores.

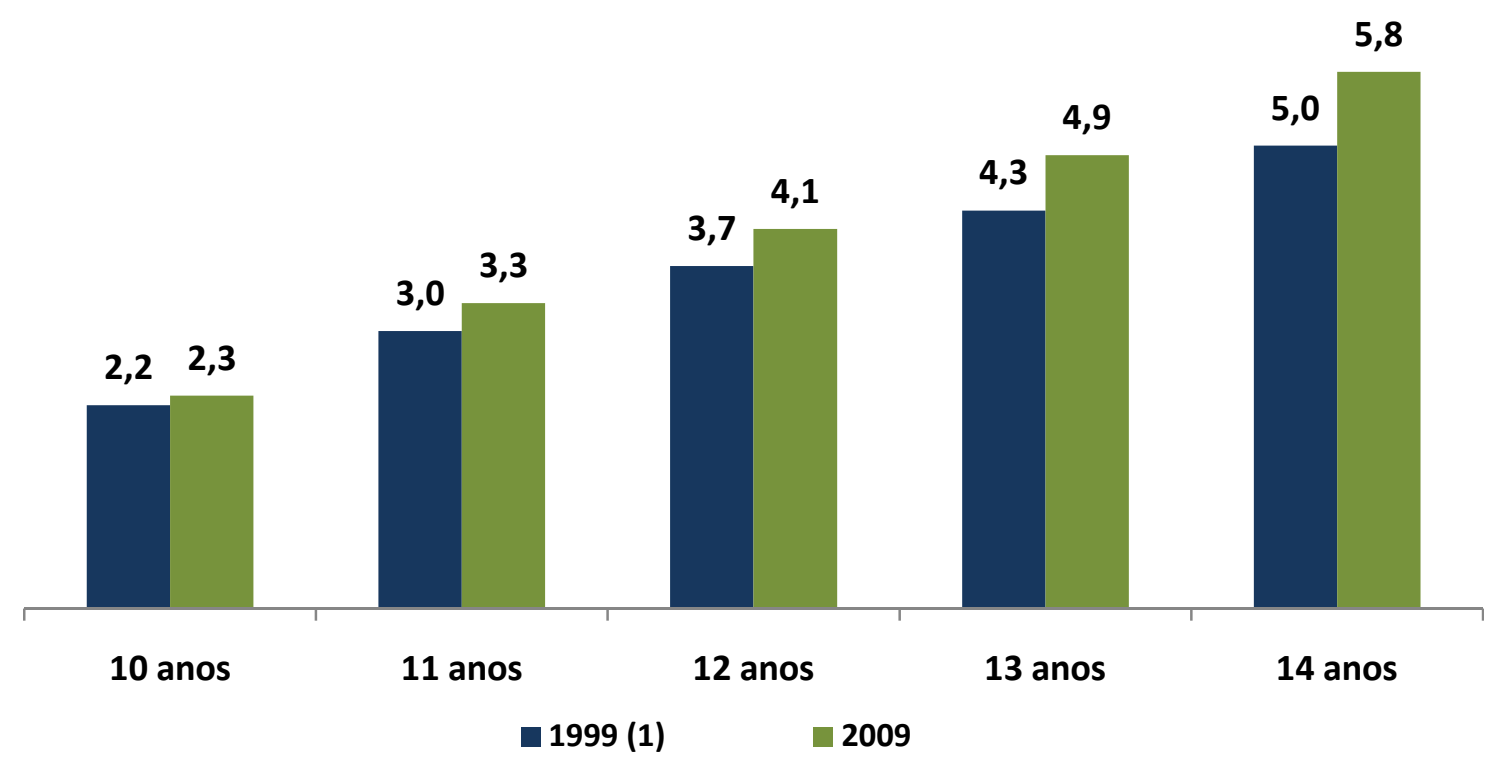

Gráfico 8: Média de anos de estudo - Brasil (1999/2009)

(1)Exclusive população rural de Rondônia, Acre, Amazonas, Roraima e Amapá. Fonte: IBGE, 2010e.

Ademais, de maneira similar ao impacto qualitativo causado pela educação, pode-se mencionar também o maior acesso à informação, pois aquele consumidor mais bem informado tende a ser mais seletivo nas suas escolhas.

\subsection{Perfil de consumo alimentar}

As pesquisas de orçamentos familiares (POF) realizadas pelo IBGE fornecem diversas informações sobre o consumo alimentar das famílias no Brasil, permitindo traçar um perfil do consumo dessas famílias e, com base na comparação de suas edições, perceber as alterações que vêm sucedendo neste âmbito.

Tais pesquisas visam principalmente mensurar as estruturas de consumo, dos gastos em geral, dos rendimentos e parte da variação patrimonial das famílias. 
Têm a duração de um ano, uma vez que buscam contemplar as modificações a que estão sujeitas as pessoas, em virtude da diversidade de itens e suas frequências de aquisição. A última POF realizou-se em 2008/2009 (IBGE,2010b), correspondendo à quinta pesquisa do gênero, sendo as anteriores o Estudo Nacional de Despesa Familiar - Endef 1974/1975 (IBGE, 1978); a POF 1987/1988 (IBGE, 1991); a POF 1995/1996 (IBGE; 1997) e a POF 2002/2003 (IBGE, 2004).

\subsubsection{Comparação do consumo no tempo}

Quando comparados os dados do Estudo nacional da despesa familiar ENDEF 1974/1975 com os da POF 2008/2009, referentes a São Paulo, percebem-se expressivas mudanças nos hábitos de consumo.

Em 1974/1975, os gastos com alimentação na região metropolitana de São Paulo, com base no Endef, representavam, em média, 16\% das despesas totais das famílias, conforme aponta a Tabela 15. Naquela ocasião, de cada 100 unidades monetárias gastas com alimentação, 83 delas eram direcionadas para aquisição de produtos alimentícios para serem consumidos dentro do domicílio, e apenas 17 unidades para gastos com alimentação fora do lar.

Já em 2009, reduziu-se ligeiramente a participação dos gastos com alimentação, representando $14,5 \%$ das despesas totais. Entretanto, para as mesmas 100 unidades monetárias, os gastos direcionados para a alimentação fora do lar atingiram 42. Em suma, os gastos com alimentação fora do lar passaram de 2,7\% para 6,2\% das despesas totais num período de 35 anos (2009-1974).

Embora na RMSP o hábito de comer fora de casa se expresse de maneira mais acentuada, a tendência pode ser observada em todo o país. Com base nos mesmos dados do ENDEF 1974/1975, os gastos com alimentação no Brasil representavam em média $25,3 \%$ das despesas totais, dos quais os gastos com alimentação fora do lar detinham fatia inferior a 10\%, isto é, significavam $2,5 \%$ do total de despesas das famílias. Em 2009, a POF aferiu que esses gastos foram reduzidos a 16,1\% das despesas totais, porém, os gastos com alimentação fora do lar corresponderam a uma expressiva fatia de 30\%, determinando 5,0\% das despesas das famílias. 
Tabela 15 : Percentual das despesas das famílias por faixa de renda - Brasil e RMSP (1974/75 e 2008/09)

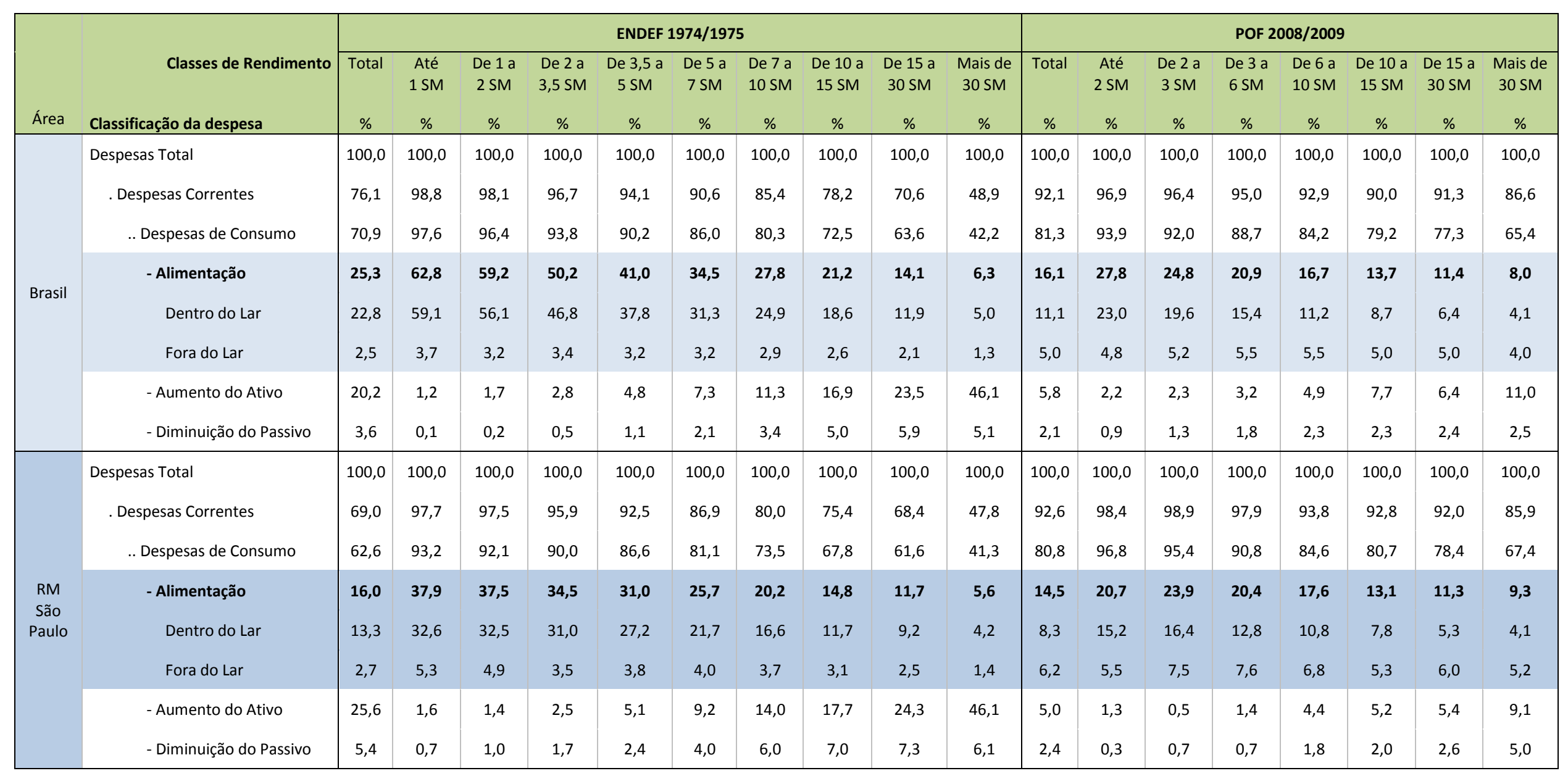

Fonte: Elaborado pela autora (IBGE, 1978, 2010b). 
No âmbito do consumo domiciliar, verificou-se que, ao longo desses 35 anos, o consumo anual de alimentos que era de 368 quilos per capita caiu para 240 quilos. Paralelamente, o consumo de bebidas que era de 17 quilos aumentou consideravelmente, atingindo 56 quilos, fruto principalmente da incorporação crescente do hábito de se beberem refrigerantes (conforme ilustra a Tabela 20, no Anexo A) (IBGE, 1978, 2010b). Cumpre deixar claro que o aumento da participação das refeições fora do lar é o principal impactante na redução da quantidade consumida dentro do domicílio, no período de tempo entre as pesquisas.

Ainda quando comparados os dados de São Paulo do ENDEF 1974/1975 com os da POF 2008/2009, por categoria de produto $^{18}$, são observadas expressivas variações nas quantidades consumidas per capita, dentro do domicílio. Exemplos:

- Arroz: diminuição de 46 para 19 quilos.

- Feijão: reduziu 19 para 5 quilos.

- Hortaliças: decresceu de 60 para 26 quilos.

- Frutas: aquelas de clima tropical tiveram redução de 45 para 31 quilos; e as de clima temperado aumentaram de 5 para 6 quilos.

- Farinhas e massas: decresceram de 11 para 8 quilos.

- Carnes bovinas: diminuíram de 20 para 14 quilos.

- Carnes suínas: reduziram de 6 para 5 quilos.

- Pescados: decresceram de 5 para 2 quilos.

- Aves: reduziram de 11 para 9 quilos.

- Laticínios: reduziram de 60 para 49 quilos.

- Açúcares e doces: decresceram de 26 para 15 quilos.

- Óleos e gorduras: aumentaram de 6 para 8 quilos.

- Sais e condimentos: reduziram de 7 para 5 quilos.

${ }^{18}$ Os dados da Endef 1974/1975 referem-se à região metropolitana de São Paulo, enquanto os dados das demais POFs são do município de São Paulo. 
Os dados, em São Paulo, demonstram uma forte mudança de hábito, quer seja por alteração no cardápio, quer pelo aumento do número de refeições realizadas fora do lar.

\subsubsection{Diferenciação regional}

As diferenças de consumo também são expressivas quando este é comparado nas capitais brasileiras. Para efeitos de análise, foram selecionadas, além de São Paulo, algumas outras de forma a se avaliarem distinções nas regiões do Brasil: Rio de Janeiro, Belo Horizonte, Porto Alegre, Cuiabá, Manaus e Salvador (Tabela 16 e Anexo B).

Tabela 16: Consumo Alimentar por Capitais Selecionadas

\begin{tabular}{|l|c|c|c|c|c|c|c|c|}
\hline \multicolumn{1}{|c|}{ Produtos } & Brasil & $\begin{array}{c}\text { São } \\
\text { Paulo }\end{array}$ & $\begin{array}{c}\text { Rio de } \\
\text { Janeiro }\end{array}$ & $\begin{array}{c}\text { Belo } \\
\text { Horizonte }\end{array}$ & $\begin{array}{c}\text { Porto } \\
\text { Alegre }\end{array}$ & Cuiabá & Manaus & Salvador \\
\hline Cereais e leguminosas & 39,0 & 24,5 & 27,7 & 23,0 & 23,3 & 34,9 & 29,6 & 19,3 \\
\hline Hortaliças & 27,1 & 26,7 & 34,4 & 30,3 & 37,5 & 29,3 & 14,5 & 26,9 \\
\hline Frutas & 28,9 & 37,1 & 38,5 & 43,1 & 40,8 & 35,7 & 20,0 & 28,2 \\
\hline Cocos, castanhas e nozes & 1,3 & 0,3 & 0,2 & 0,3 & 0,1 & 0,1 & 0,7 & 0,6 \\
\hline Farinhas, féculas e massas & 18,1 & 7,9 & 10,6 & 9,0 & 8,4 & 10,9 & 26,2 & 12,6 \\
\hline Panificados & 21,5 & 26,7 & 28,1 & 27,5 & 28,4 & 18,3 & 31,3 & 31,6 \\
\hline Carnes & 25,4 & 21,0 & 27,2 & 21,2 & 28,5 & 26,9 & 29,8 & 18,9 \\
\hline Vísceras & 0,7 & 0,3 & 0,6 & 0,8 & 0,8 & 0,4 & 1,2 & 1,2 \\
\hline Pescados & 4,0 & 2,0 & 4,4 & 2,0 & 1,0 & 2,1 & 16,5 & 3,5 \\
\hline Aves e ovos & 16,4 & 11,3 & 19,6 & 15,9 & 15,2 & 14,6 & 30,4 & 15,7 \\
Laticínios & 43,7 & 48,8 & 47,4 & 58,6 & 68,9 & 48,9 & 16,7 & 25,4 \\
\hline Açúcares, doces e confeitaria & 20,5 & 14,9 & 16,4 & 14,5 & 14,8 & 14,9 & 16,5 & 13,6 \\
\hline Sais e condimentos & 5,4 & 5,3 & 5,7 & 4,3 & 4,3 & 4,8 & 3,5 & 4,3 \\
\hline Óleos e Gorduras & 8,9 & 8,1 & 7,6 & 8,2 & 7,6 & 9,8 & 7,5 & 5,4 \\
\hline Alimentos preparados e misturas & 3,5 & 5,3 & 3,2 & 5,4 & 6,9 & 5,2 & 3,7 & 1,6 \\
\hline Outros produtos & 0,0 & - & - & 0,0 & - & - & - & - \\
\hline SUBTOTAL & $\mathbf{2 6 4 , 5}$ & $\mathbf{2 4 0 , 3}$ & $\mathbf{2 7 1 , 5}$ & $\mathbf{2 6 4 , 0}$ & $\mathbf{2 8 6 , 4}$ & $\mathbf{2 5 6 , 9}$ & $\mathbf{2 4 8 , 0}$ & $\mathbf{2 0 8 , 7}$ \\
\hline Bebidas e infusões & 50,7 & 55,5 & 63,7 & 57,0 & 80,1 & 53,1 & 62,4 & 45,8 \\
\hline TOTAL & $\mathbf{3 1 5 , 2}$ & $\mathbf{2 9 5 , 8}$ & $\mathbf{3 3 5 , 2}$ & $\mathbf{3 2 1 , 0}$ & $\mathbf{3 6 6 , 5}$ & $\mathbf{3 0 9 , 9}$ & $\mathbf{3 1 0 , 4}$ & $\mathbf{2 5 4 , 6}$ \\
\hline
\end{tabular}

Fonte: IBGE, 2010b.

Excluindo-se as bebidas, o menor consumo alimentar per capita anual é o de Salvador, com 209 quilos, e o maior, Porto Alegre, com 286 quilos. Em São Paulo, atingiu 240 quilos, ficando abaixo do Rio de Janeiro, Belo Horizonte, Cuiabá e Manaus. Uma leitura rápida levaria à dedução de que se come menos em São 
Paulo, entretanto, há que se enfatizar a importância da alimentação fora do domicílio nesta capital.

Quando se analisa o consumo alimentar de forma quantitativa dentre capitais brasileiras, verificam-se amplas diferenças de hábito, conforme apresentado a seguir, chamando atenção para a quantidade em quilos per capita/ano da média Brasil que está expressa a seguir da categoria:

- Arroz (26): a média Brasil é de 26 quilos; São Paulo, Rio de Janeiro e Belo Horizonte apresentam consumo da ordem de 17 quilos; por outro lado Cuiabá atinge 28; e Salvador menos de 10.

- Feijão (10): em Manaus, consumo próximo da média; em São Paulo é menos da metade, isto é, inferior a 5; e no Rio de Janeiro, próximo de 8.

- Hortaliças (27): menor consumo em Manaus, com 14; e o maior, em Porto Alegre, com 38. Em São Paulo é equivalente à média, isto é, 27 quilos.

- Frutas (29): aqui também Manaus apresenta o menor consumo com 20 quilos; o maior se verifica em Belo Horizonte, com 43. Em São Paulo atinge 37 quilos.

- Farinhas (9): Manaus atinge 14, enquanto que São Paulo e Belo Horizonte, fica na ordem de 2 quilos; no Rio de Janeiro próximo de 4; e em Salvador, 7.

- Carnes bovinas (17): Rio de Janeiro equivalente à média; em Belo Horizonte, o menor consumo com menos de 12; seguido por Salvador, 13; São Paulo, 14; e Cuiabá e Manaus acima dos 20 quilos per capita.

- Carne suínas (6): Porto Alegre, Rio de Janeiro e Belo Horizonte, próximos de 7; e os menores consumos verificados em Manaus e Salvador, com cerca de 3 quilos; em São Paulo é inferior a 5 quilos.

- Aves (13): em Manaus é o dobro, 26 quilos; enquanto que em São Paulo é inferior a 9 quilos.

- Pescados (4): em Manaus supera os 16 quilos; atinge apenas 2 quilos em São Paulo; e em Porto Alegre é inferior a 1 quilo per capita/ano.

- Laticínios (44): maior consumo verificado em Porto Alegre, com 69 quilos; seguido de Belo Horizonte, com 59 quilos; São Paulo, Rio de Janeiro e 
Cuiabá, na ordem de 48 quilos; e os menores consumos encontrados em Salvador, com 25 quilos; e Manaus, com 16.

Deve-se notar ainda que nas categorias de produtos, há também distinções regionais. Em relação a pescados, por exemplo, vale destacar a divisão entre peixes de água salgada e doce. Enquanto em São Paulo, apesar do baixo consumo, $90 \%$ dos pescados consumidos são de água salgada, em Manaus e Cuiabá, a situação se inverte, em decorrência da distância do mar e da riqueza dos rios da região.

\subsubsection{Visão pelos estratos de renda}

Tendo por referência a última POF, o consumo alimentar anual per capita no Brasil foi de 315 quilos e, quando desconsideradas as bebidas, atinge 265 quilos (Tabela 17 e Anexo C).

$\mathrm{Na}$ faixa de renda mais alta pesquisada, acima dos 15 salários-mínimos, o consumo de alimentos atingiu 351 quilos, e o de bebidas, 108 quilos. Por outro lado, na faixa de menor renda, até 2 salários-mínimos, o consumo de alimentos foi de 203 quilos, isto é, $23 \%$ menor do que a média brasileira e $42 \%$ menor que aquela de renda mais elevada. Tais números por si só demonstram as evidentes diferenças quantitativas que são observadas na alimentação dos brasileiros.

Por outro lado, analisando-se as diferenças de consumo das famílias do estrato superior de renda da POF 2008/2009 (acima de 15 salários-mínimos) em relação à média Brasil, merecem destaque as seguintes:

- Arroz e Feijão: os mais ricos (acima de 15 salários-mínimos) consomem 30\% a menos de arroz e $20 \%$ a menos de feijão que a média per capita brasileira.

- Hortaliças: $64 \%$ a mais que a média, tendo alguns itens como berinjela, brócolis e couve-flor superado $200 \%$.

- Frutas: no total, consomem o dobro da média. Entretanto, quando se refere a morango, pera, pêssego, ameixa e caqui, o consumo é três vezes maior. 
- Farinhas: consomem um terço a menos que a média brasileira, e quando se trata de farinha de mandioca são dois terços a menos; porém, com relação à farinha de rosca, consomem mais que o dobro.

- Carnes bovinas: os mais ricos superam a média em 26\%, e quando se menciona a carne de primeira, é $90 \%$ maior, sendo $540 \%$ maior com relação ao filé mignon. Por outro lado, na carne bovina de segunda, consomem 10\% a menos que a média brasileira.

- Pescados: quando se trata de peixe de água salgada, consomem $82 \%$ a mais que a média. Em contrapartida, nos peixes de água doce a situação se inverte, pois o consumo é cerca de metade da média brasileira.

- Aves: praticamente não há grande distinção por classes de renda, todavia quando se trata de peito de frango ou carne de peru, o consumo dos mais ricos atinge o triplo da média.

- Laticínios: os mais ricos consomem 52\% acima da média, e em itens como queijos consomem o triplo.

- Açúcares e doces: com relação aos açúcares, o consumo é cerca de 20\% menor, porém em doces e produtos de confeitaria é $200 \%$ maior que a média per capita brasileira.

- Óleos e gorduras: de um modo geral, o consumo é próximo em todas as faixas de renda, entretanto muda a composição interna na categoria. Óleos de oliva, girassol, canola e milho são consumidos cerca de 4 vezes mais pelos mais ricos, quando se compara à média brasileira; por outro lado, na banha de porco, o consumo é $50 \%$ menor.

- Cafés: a POF indicou média de consumo de 2,6 quilos per capita/ano, e apresentou pouca variação em função da renda, demonstrando ser um produto de todos os brasileiros.

- Alimentos preparados: os mais ricos consomem 150\% a mais que a média brasileira. 
Tabela 17: Distribuição do consumo alimentar por faixa de renda - Brasil

\begin{tabular}{|c|c|c|c|c|c|c|c|c|c|}
\hline \multirow[b]{2}{*}{ Produtos (Kg/ano) } & \multirow[b]{2}{*}{ Total } & \multicolumn{6}{|c|}{ Classes de rendimento (Salários-Mínimos) } & \multirow{2}{*}{$\begin{array}{c}>15 \\
\text { SM/ } \\
\text { Brasil }\end{array}$} & \multirow[b]{2}{*}{$\begin{array}{c}>15 \mathrm{M} / \\
\text { Até } 2\end{array}$} \\
\hline & & Até 2 & $\begin{array}{c}\text { De } 2 \\
\text { a } 3\end{array}$ & $\begin{array}{c}\mathrm{De} 3 \\
\text { a } 6\end{array}$ & $\begin{array}{l}\text { De } 6 \\
\text { a } 10\end{array}$ & $\begin{array}{c}\text { De } 10 \\
\text { a } 15\end{array}$ & $\begin{array}{l}\text { Mais } \\
\text { de } 15\end{array}$ & & \\
\hline Cereais e Leguminosas & 39,0 & 40,9 & 41,7 & 41,2 & 36,3 & 35,6 & 30,0 & 0,8 & 0,7 \\
\hline Hortaliças & 27,1 & 15,4 & 22,6 & 27,1 & 32,6 & 35,1 & 44,3 & 1,6 & 2,9 \\
\hline Frutas & 28,9 & 14,3 & 20,4 & 27,2 & 35,8 & 41,1 & 59,3 & 2,1 & 4,2 \\
\hline Cocos, castanhas e nozes & 1,3 & 1,4 & 1,4 & 1,5 & 0,8 & 0,8 & 1,0 & 0,8 & 0,7 \\
\hline Farinhas, féculas e massas & 18,1 & 21,1 & 19,4 & 18,2 & 15,7 & 14,9 & 15,7 & 0,9 & 0,8 \\
\hline Panificados & 21,5 & 15,3 & 19,2 & 21,4 & 24,7 & 26,0 & 30,4 & 1,4 & 2,0 \\
\hline Carnes & 25,4 & 17,9 & 22,2 & 25,5 & 30,3 & 33,7 & 31,9 & 1,3 & 1,8 \\
\hline Vísceras & 0,7 & 0,6 & 0,8 & 0,8 & 0,7 & 0,7 & 0,5 & 0,7 & 0,8 \\
\hline Pescados & 4,0 & 4,5 & 4,3 & 3,7 & 3,5 & 3,2 & 5,1 & 1,3 & 1,1 \\
\hline Aves e ovos & 16,4 & 14,0 & 15,9 & 16,8 & 17,9 & 17,3 & 18,2 & 1,1 & 1,3 \\
\hline Laticínios & 43,7 & 25,1 & 36,0 & 43,8 & 53,8 & 60,8 & 66,3 & 1,5 & 2,6 \\
\hline Açúcares, doces e confeitaria & 20,5 & 19,3 & 20,5 & 21,1 & 19,0 & 21,2 & 23,4 & 1,1 & 1,2 \\
\hline Sais e condimentos & 5,4 & 4,2 & 4,9 & 5,6 & 5,9 & 6,2 & 7,1 & 1,3 & 1,7 \\
\hline Óleos e gorduras & 8,9 & 7,6 & 8,7 & 9,2 & 9,4 & 9,8 & 9,9 & 1,1 & 1,3 \\
\hline Alimentos preparados e misturas & 3,5 & 1,4 & 1,8 & 2,9 & 4,9 & 6,5 & 8,4 & 2,4 & 6,1 \\
\hline Outros produtos & 0,0 & 0,0 & 0,1 & 0,0 & 0,1 & 0,0 & 0,1 & 1,3 & 1,8 \\
\hline SUBTOTAL & 264,5 & 203,1 & 239,9 & 266,0 & 291,3 & 313,1 & 351,6 & 1,3 & 1,7 \\
\hline Bebidas e infusões & 50,7 & 21,6 & 34,1 & 46,5 & 67,1 & 76,9 & 107,7 & 2,1 & 5,0 \\
\hline TOTAL & 315,2 & 224,7 & 274,0 & 312,5 & 358,4 & 390,0 & 459,3 & 1,5 & 2,0 \\
\hline
\end{tabular}

Fonte: IBGE, 2010b.

Complementando a questão, é interessante verificar a diferença na participação dos gastos com alimentação dentro e fora do lar, em São Paulo, nas diversas classes de rendimento, ao longo do tempo, conforme ilustra o Gráfico 9. 


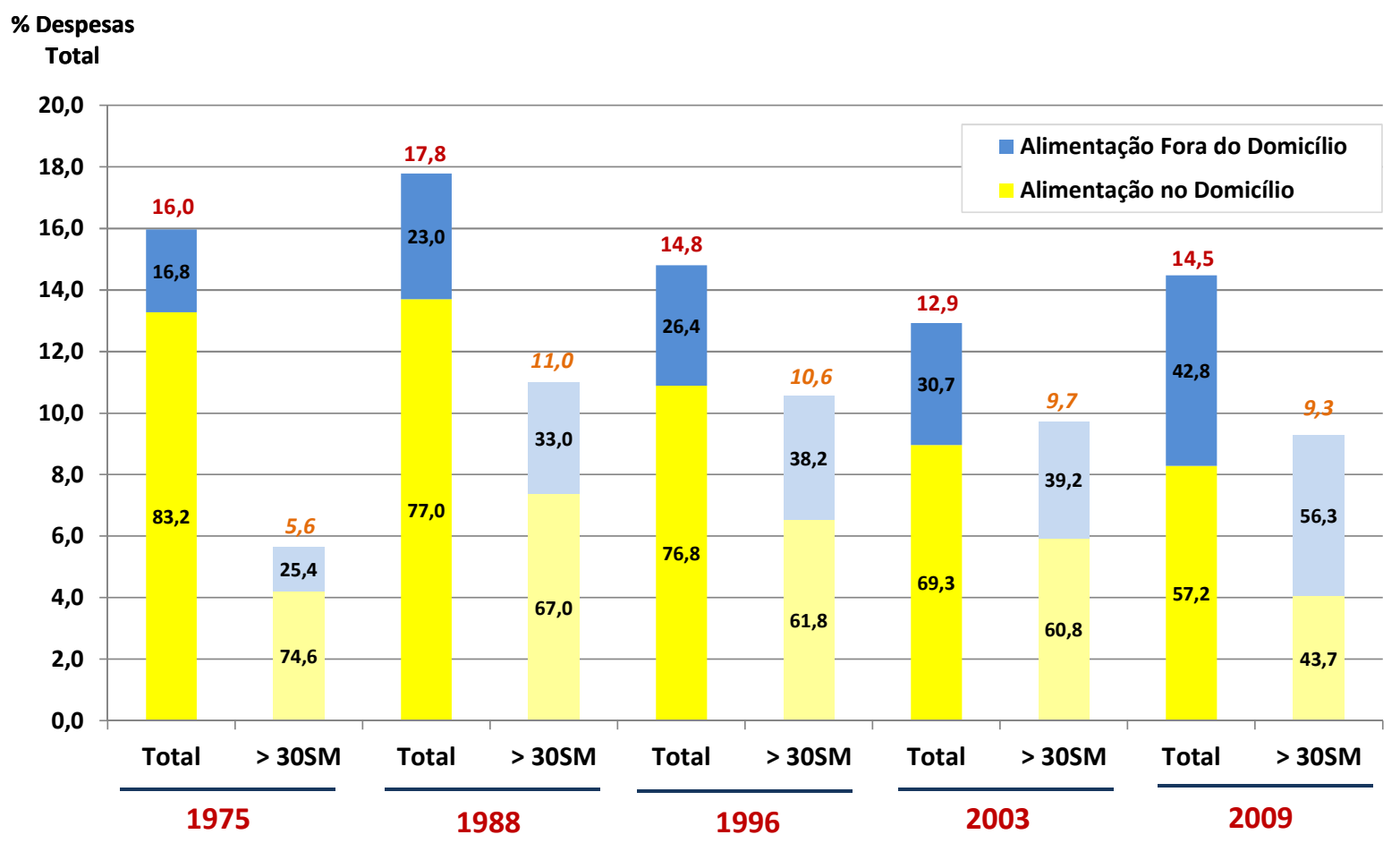

Gráfico 9: Gastos com alimentação dentro e fora do lar (Região Metropolitana de São Paulo)

Fonte: Elaborado pela autora (IBGE, 1978; IBGE, 2010b).

Como se pode verificar, no âmbito do comportamento dos habitantes da região metropolitana de São Paulo, amplia-se consistentemente o hábito de comer fora de casa, em todas as faixas de renda.

Marcante ainda é o fato de na classe com maior rendimento, ou seja, entre aqueles cujo rendimento é superior a 30 salários mínimos, os gastos com alimentação fora do lar terem ultrapassado os gastos com alimentação no domicílio, representando $56 \%$ dos gastos totais com alimentação.

Ainda sobre o tema, pesquisa desenvolvida pela FIESP/IBOPE constata que não só a frequência, mas também o estilo do programa estão diretamente relacionados às condições financeiras e sociais dos entrevistados. Assim, entre aqueles com maior nível de escolaridade e os que detêm maior renda, 0 ato de comer fora está mais atrelado ao prazer do que à necessidade de se alimentar, sendo maior a gama de experiências relatadas. (FIESP; IBOPE, 2010). 


\subsection{Tendências no consumo alimentar}

Acompanhando as transformações na sociedade, e como parte delas, vão se delineando, ao longo do tempo, novas relações dos indivíduos com a comida, enquanto ela própria parece se deslocar da categoria de mercadoria para a de experiência.

Vale ressaltar que, apesar de o crescimento da demanda por alimentos vir sendo observado, e ainda haver fome no mundo (FAO, 2010), hoje ela é reflexo, ao menos por enquanto, principalmente da má distribuição de recursos, da logística, e não de uma restrição de oferta global. Em muitas economias os mercados encontram-se saturados e "mudaram de supridores para orientados pela demanda", de modo que "estar em contato com as exigências do consumidor tornou-se um trunfo competitivo" (ZUURBIER, 2000, p.404).

Num ambiente em acelerada transformação, com intensos fluxos econômicos, políticos, sociais e culturais, mudanças de comportamento e dos hábitos de consumo são esperadas em intervalos de tempo cada vez menores (BARBOSA et al. , 2010).

Assim, os produtos devem ser desenvolvidos para atender a consumidores cada vez mais exigentes, e devem ser capazes de satisfazer diferentes gostos e necessidades (ZUURBIER, 2000, p.39). Para Zylbersztajn (2000, p.16):

O consumidor moderno vem apresentando algumas mudanças que são fruto da globalização dos hábitos e padrões, preocupação com a qualidade e aspectos de saúde, valorização do seu tempo, o que tem implicações na valorização dos atributos que caracterizam um certo produto e que determina a decisão final do consumidor .

Nesse sentido, Barbosa e seus colegas (2010, p. 39) ressaltam, em estudo que cruza os dados obtidos em pesquisas setoriais realizados em diversos países da União Europeia, no Canadá, nos Estados Unidos e no Brasil, cinco tendências observadas mundialmente quando se trata de alimentação. São elas: 
- Sensorialidade e prazer

Destaca, entre outros elementos, a crescente valorização da culinária e da gastronomia, e a busca por produtos de maior valor agregado.

- Saudabilidade e bem-estar

Reflete a escolha pelo alimento mais saudável, mesmo que ele seja mais caro.

- Conveniência e praticidade

Demonstra a falta de tempo dos entrevistados de cozinhar em casa e a busca por produtos que facilitem o seu dia a dia.

- Qualidade e confiabilidade

Comprova, por exemplo, que na hora da compra do alimento a marca é um dos fatores mais importantes.

- Sustentabilidade e ética

Salienta a preferência dos consumidores por marcas que desenvolvem projetos sociais e protegem o meio ambiente.

Cada uma dessas tendências corresponde a uma série de atributos que vêm sendo valorizados pelos consumidores de diferentes países, como ilustrado no Quadro 2.

Com objetivo de verificar a aderência do Brasil às tendências observadas internacionalmente, um estudo de segmentação atitudinal foi consolidado no relatório "Brasil Food Trends 2020" (FIESP; IBOPE, 2010). Os resultados revelam que as tendências de "sensorialidade e prazer", "conveniência e praticidade" e "qualidade e confiabilidade" são percebidas pelos brasileiros individualmente e com os mesmos atributos destacados pelas demais pesquisas, enquanto as tendências de "saudabilidade e bem-estar" e "sustentabilidade e ética" são entendidas como uma só tendência.

No entanto, deve-se considerar que, mesmo se tratando das tendências que se manifestam individualmente, isso não significa que elas não estejam vinculadas. Por exemplo, quando se opta por consumir um vinho francês biodinâmico, três 
tendências aparecem combinadas: sensorialidade e prazer; saudabilidade e bemestar; e sustentabilidade e ética.

\begin{tabular}{|c|c|c|}
\hline $\begin{array}{l}\text { Tendências da } \\
\text { Alimentação }\end{array}$ & \multicolumn{2}{|c|}{$\begin{array}{l}\text { Exemplos de características valorizadas pelos } \\
\text { consumidores em diferentes países }\end{array}$} \\
\hline $\begin{array}{c}\text { Sensorialidade e } \\
\text { Prazer }\end{array}$ & $\begin{array}{l}\text { - Valorização da culinária e da gastronomia } \\
\text { - Produtos com maior valor agregado } \\
\text { (gourmet, iguarias, premuim, delicatessen) } \\
\text { - Variação de sabores } \\
\text { - Produtos com forte apelo sensorial } \\
\text { - Produtos com apelo à indulgência } \\
\text { - Alimentos exóticos } \\
\text { - Culinária de regiões específicas (produtos } \\
\text { étnicos) }\end{array}$ & $\begin{array}{l}\text { - Produtos com embalagem e design } \\
\text { diferenciados } \\
\text { - Recuperação de culinárias regionais e } \\
\text { tradicionais } \\
\text { - Harmonização de alimentos e bebidas } \\
\text { - Socialização em torno da alimentação } \\
\text { - Lazer e turismo em torno da alimentação } \\
\text { (circuitos e polos gastrônomicos) } \\
\text { - Produtos e embalagens lúdicas e interativas }\end{array}$ \\
\hline $\begin{array}{l}\text { Conveniência e } \\
\text { Praticidade }\end{array}$ & $\begin{array}{l}\text { - Pratos prontos e semiprontos } \\
\text { - Produtos minimamente processados } \\
\text { - Alimentos de fácil preparo } \\
\text { - Embalagens de fácil abertura, fechamento e } \\
\text { - descarte } \\
\text { - Produtos para o forno microondas } \\
\text { - Kits para preparo de refeições }\end{array}$ & $\begin{array}{l}\text { - Produtos em pequenas porções (snacking, } \\
\text { finger food) } \\
\text { - Produtos embalados para consumo } \\
\text { individual (monodoses) } \\
\text { - Produtos adequados para comer em trânsito } \\
\text { - Produtos adequados para consumo em } \\
\text { diferentes lugares e situações } \\
\text { - Serviços e produtos de delivery }\end{array}$ \\
\hline $\begin{array}{l}\text { Qualidade e } \\
\text { Confiabilidade }\end{array}$ & $\begin{array}{l}\text { - Produtos com rastreabilidade e garantia de } \\
\text { origem } \\
\text { - Processos seguros de produção e } \\
\text { distribuição } \\
\text { - Processos de gerenciamento de riscos } \\
\text { - Certificados e selos de qualidade e } \\
\text { segurança } \\
\text { - Rotulagem informativa }\end{array}$ & $\begin{array}{l}\text { - Produtos com credibilidade de marca } \\
\text { - Processos com tecnologia de ponta (nano e } \\
\text { biotecnologia, radiofrequência etc.) } \\
\text { - Embalagens ativas e inteligentes } \\
\text { - Boas práticas de fabricação } \\
\text { - Produtos e serviços padronizados }\end{array}$ \\
\hline $\begin{array}{c}\text { Saudabilidade e } \\
\text { Bem-Estar }\end{array}$ & $\begin{array}{l}\text { - Produtos benéficos ao desempenho físico e } \\
\text { mental } \\
\text { - Produtos benéficos à saúde cardiovascular } \\
\text { - Produtos benéficos à saúde gastrointestinal } \\
\text { (probióticos, prebióticos e simbióticos) } \\
\text { - Produtos para dietas específicas e alergias } \\
\text { alimentares } \\
\text { - Produtos com aditivos e ingredientes } \\
\text { naturais } \\
\text { - Alimentos de alto valor nutritivo agregado } \\
\text { (funcionais) } \\
\text { - Produtos isentos ou com teores reduzidos } \\
\text { de sal, açúcar e gorduras (better-for-you) } \\
\text { - Produtos fortificados }\end{array}$ & $\begin{array}{l}\text { - Produtos diet/light } \\
\text { - Produtos orgânicos } \\
\text { - Produtos energéticos } \\
\text { - Produtos para esportistas } \\
\text { - Produtos minimamente processados } \\
\text { - Produtos vegetais (frutas, hortaliças, flores e } \\
\text { plantas medicinais) } \\
\text { - Produtos com propriedades cosméticas } \\
\text { - Produtos com selo de qualidade de } \\
\text { sociedades médicas }\end{array}$ \\
\hline $\begin{array}{c}\text { Sustentabilidade } \\
\text { e Ética }\end{array}$ & $\begin{array}{l}\text { - Produtos de empresas sustentáveis } \\
\text { - Empresas com programas avaliados e } \\
\text { certificados de responsabilidade } \\
\text { socioambiental } \\
\text { - Produto com menor "pegada" de carbono } \\
\text { (carbon footprint) } \\
\text { - Produtos de baixo impacto comercial } \\
\text { - Produtos associados ao bem-estar animal } \\
\text { - Rotulagem ambiental e social } \\
\text { - Produtos de sistema fairtrade } \\
\text { - Embalagens recicláveis e recicladas }\end{array}$ & $\begin{array}{l}\text { - Revalorização de materiais } \\
\text { - Processos com utilização de fontes } \\
\text { renováveis } \\
\text { - Gerenciamento de resíduos e emissões } \\
\text { - Certificações e selos ambientais } \\
\text { - Produtos vinculados a causas sociais e } \\
\text { ambientais } \\
\text { - Produtos e embalagens racionalizados } \\
\text { - Processos produtivos sustentáveis } \\
\text { - Processos eficientes }\end{array}$ \\
\hline
\end{tabular}

\section{Quadro 2: As tendências da alimentação}

Fonte: Adaptado de Barbosa et al., 2010.

Observando-se o quadro, é possível ainda confirmar a dialética que envolve a alimentação, já abordada anteriormente. Nesse sentido, podemos destacar paralelamente a valorização de produtos industrializados, prontos e semiprontos, e 
de produtos artesanais, de regiões específicas, ou ainda de produtos com embalagem de fácil abertura e descarte e outros com embalagens recicláveis, menos custosas.

$\mathrm{Na}$ mesma direção do que foi mencionado por Barbosa e colaboradores (2010), uma pesquisa realizada pela Apex-Brasil (APEX, 2009) com base em dados de análise de mercado e preferência dos consumidores detectou que há uma crescente demanda por produtos que propiciem experiências sensoriais, ou que sejam naturais, exóticos, sustentáveis ou orgânicos.

No âmbito do comportamento dos brasileiros, uma tendência que já aparece consolidada é o hábito de comer fora de casa, como já abordado. Diante de tal cenário, na sequência serão destacados alguns aspectos da restauração na cidade de São Paulo.

\subsection{Restaurantes}

Os restaurantes de São Paulo acompanham e refletem não só as mudanças do mercado de alimentação como também as alterações socioculturais que se desenvolvem na cidade.

Nesse sentido, é pertinente salientar a magnitude desse mercado na atualidade. Somente em São Paulo, há cerca de 12,5 mil estabelecimentos, com diferentes características (ABRASEL, 2009); número este que vem crescendo de maneira acelerada, acompanhando a tendência de aumento das refeições realizadas fora do domicílio (ECD, 2010).

Deve-se notar, igualmente, o importante papel desses restaurantes na composição de uma imagem de cidade cosmopolita, sendo destacados ainda como valiosos diferenciais do município e ajudando a consolidar São Paulo como polo gastronômico brasileiro. Assim, mesmo sem qualquer intenção de se contar a complexa história dos restaurantes da cidade $^{19}$, ou parte dela, convém realçar 0

\footnotetext{
${ }^{19}$ Arnaldo Lorençato está finalizando um livro sobre a história dos restaurantes em São Paulo, com lançamento previsto para 2011. Josimar Melo e Ricardo Maranhão também estão desenvolvendo um livro sobre o tema, mas ainda sem previsão de lançamento.
} 
envolvimento e a influência de estrangeiros na multiculturalidade dessa oferta desde os primórdios de sua consolidação, destacando-se também o ecletismo da oferta paulistana veiculada pela mídia desde o terceiro quartil do século $X X$.

A formalização dos serviços de alimentação em São Paulo remonta ao século XIX, com a inauguração dos primeiros restaurantes, confeitarias e cafés (SILVA, 2008; BARBUY, 2006); até então, o que havia eram quitandeiras oferecendo algumas iguarias pela cidade e uma ou outra casa de pasto, fora da zona central, cuja finalidade era atender aos viajantes de passagem (SILVA, 2008).

Em 1852, existiam apenas dois restaurantes na cidade, o do Charles e o do Frederic Fontaine, ambos franceses (DINIZ,1978; FREITAS,1978), denunciando a presença estrangeira desde os primórdios da restauração paulistana.

Contudo, "ir a uma casa dessas não era então um ato que recomendasse o freguês à estima pública, trazia um não-sei-quê de desconsideração", afirma Diniz (1978, p.41). Porém, embora esses dois primeiros estabelecimentos não tivessem prestígio na cidade e frequentá-los significasse risco de desmoralização pública (BRUNO apud PODANOVSKi, 1988; DINIZ, 1978; FREITAS, 1978), a situação logo começaria a se reverter. Em pouco tempo, a introdução de hotéis e restaurantes na cidade tiraria o paulistano do seu modo de vida recatado, inaugurando uma nova fase (FREITAS, 1978).

Os anos seguintes foram marcados pela abertura de outros restaurantes, que, na tentativa de conquistar o público paulistano, por vezes aceitavam também encomendas (BARBUY, 2006). O berço dessa nova restauração foram os hotéis ${ }^{20}$, nos quais a exaltação à culinária francesa, que havia aportado no Brasil com a família real, se fez marcante (BARBUY, 2006; Podanovsky, 1988).

Tais estabelecimentos correspondem a uma fase de transição na cidade. Para Barbuy (2006, p. 111-112),

[Essas] primeiras iniciativas de restaurantes, em meados do século XIX [...] foram ensaios precursores na introdução de hábitos cosmopolitas na cidade, mas somente na década de 1870 é que os primeiros restaurantes a serem bem aceitos nos códigos de urbanidade começariam a integrar-se ao cotidiano da cidade, implantados, no mais das vezes, por indivíduos originários do norte e do leste europeus, que aqui eram genericamente denominados "alemães".

${ }^{20}$ Como exemplos,podem ser citados os hotéis da Providência e Paulistano, ambos de 1854, e do Hotel des Voyageurs, de 1857; e depois de 1860, dos Hotéis Itália, Europa, Globo, 4 Nações, de Franca, entre outros (Barbuy, p.92 et seq.; Podanovski p.17. 
São Paulo dava, pois, por meio dos restaurantes (ainda que não só deles), seus primeiros passos na direção de cidade cosmopolita. E o número de estabelecimentos aumentava, sendo registrados, em 1890, 17 deles na capital paulista (DA SILVA, 2008).

Nessa época, conforme exposto anteriormente, as levas de imigrantes já desembarcavam em grande número, transformando a rotina e a dimensão da cidade. Com isso, a culinária que se estabelecera nos restaurantes até então ganharia a companhia de outros hábitos imigrantes.

Com o passar dos anos, a multiplicação da ancestralidade imigrante (IBGE, 2006) e o êxito alcançado por eles, em decorrência das favoráveis condições de mercado (Klein, 2000), impulsionaram a oferta formal de alimentos étnicos e o despontar de estabelecimentos voltados para tais cozinhas.

De acordo com Melo e Maranhão (2003), os italianos, aqueles que vieram em maior número, passaram a dominar a maior parte do mercado nas décadas seguintes, especialmente entre 1920 e 1930, quando algumas das cantinas mais antigas, ainda em funcionamento na cidade, abriram suas portas, a exemplo da Cantina Capuano (de 1907) e da Castellões (de 1924).

Podanovsky (1988), citando Armando Puglisi, afirma que, no início, muitas das cantinas ${ }^{21}$ não serviam comida, sendo a Capuano a única da região do Bixiga que o fazia desde sua inauguração. Dessa forma, elas eram, a princípio, um local aonde os homens iam para se divertir e levavam consigo o lanche preparado em casa, no mais das vezes um pão recheado com antepastos, para ser consumido na companhia dos demais. Assim, as cantinas que foram se estabelecendo mais tarde corresponderiam a restaurantes à la carte, que se reportavam ao clima dos empórios por meio dos objetos pendurados.

Dentre esses imigrantes italianos dedicados ao ramo da alimentação, Francesco Masano, bisavô da autora, ao chegar da Itália com mulher e filhos, em 1935, montou uma cantina na Lapa, localizada na confluência da rua Faustolo com a Vespasiano, distante 100 metros do antigo Tendal, à época, o entreposto de carnes da cidade de São Paulo. Seguindo a tradição familiar, Carmelo Masano, avô da autora, foi sócio do restaurante existente no conjunto aquático do Clube Palmeiras nas décadas de 1970 e 1980.

\footnotetext{
${ }^{21}$ O termo cantina, em italiano designa local que vende vinho.
} 
$\mathrm{Na}$ década de 1930, surgiram também restaurantes franceses, como o Freddy, inaugurado em 1935 (o que faz dele o restaurante francês mais antigo ainda em funcionamento na cidade), que, segundo Jacques Le Goff ${ }^{22}$, corresponderiam aos estabelecimentos mais sofisticados da cidade naquela época e nas décadas seguintes.

No pós Segunda Guerra Mundial, a metrópole paulistana assistiu a um crescimento muito acelerado, exigindo um número maior de restaurantes, que se multiplicavam na cidade (MELO; MARANHÃO, 2003). São Paulo já era então, na metade do século XX, completamente diferente. Podiam-se observar pessoas da sociedade adentrando a madrugada em restaurantes e passando noites inteiras nas boates do centro da cidade, como a do Michel, que também ofereciam serviço de restauração naquela época.

Assim, quando em 1966 surgiu, por iniciativa de Victor Civita, o primeiro guia turístico do Brasil, São Paulo era descrita como uma cidade que oferecia ao turista conforto, "com ótimos restaurantes onde você encontra comida de todos os cantos do mundo" (GUIA QUATRO RODAS,1965, p, 27) já demarcando a importância que essa oferta gastronômica representava na constituição da sua imagem.

Nessa primeira edição do Guia, foram listados 131 endereços de restaurantes paulistanos, apresentados como os melhores da cidade, dos quais 74 eram representantes de cozinhas imigrantes (em 11 categorias) e outros 35 tinham apelo de "cozinha internacional" confirmando a forte marca estrangeira nessa oferta (GUIA QUATRO RODAS, 1965).

Conquanto os restaurantes destacados em guias e roteiros não possam ser tomados como uma amostra quantitativa probabilística daquilo que há na cidade, eles demonstram a diversidade e, mais do que isso, representam uma referência de padrão de qualidade e correspondem à imagem veiculada dessa oferta.

\footnotetext{
22 Informação colhida com Jacques Le Goff mediante entrevista pessoal, realizada no restaurante Amadeus, em Dezembro/2010. Jacques Le Goff nasceu em Paris, em 1923. Tendo chegado ao Brasil em 1949 e a São Paulo no dia $1^{\circ}$ de janeiro de 1953, ele trabalhou em diferentes restaurantes franceses na cidade, tendo sido sócio do Marcel e depois do Freddy até 1989, quando foi vendido. Portanto, teve a oportunidade de conviver com os irmãos Freddy e Marcel, que podem ser considerados precursores na gastronomia paulistana.
} 
Tabela 18: Restaurantes por categoria (1966 - 2011)

\begin{tabular}{|c|c|c|c|c|c|c|c|c|c|c|}
\hline CATEGORIA & 1966 & 1971 & 1976 & 1981 & 1986 & 1990 & 1996 & 2001 & 2006 & 2011 \\
\hline Brasileira & 4 & 8 & 10 & 20 & 12 & 6 & 7 & 2 & 2 & 4 \\
\hline Baiana & & & & & & & & 3 & 3 & 3 \\
\hline Capixaba & & & & & & & & 1 & 1 & 1 \\
\hline Feijoada & & & & & & & & 1 & 1 & 1 \\
\hline Maranhense & & & & & & & & 1 & 1 & \\
\hline Mineira & & & & & & & 4 & 5 & 6 & 3 \\
\hline Nordestina & & & & & & & & 1 & 3 & 4 \\
\hline Paraense & & & & & & & & 1 & & 1 \\
\hline Sul - Matogrossense & & & & & & & & & & 1 \\
\hline Churrascaria & 17 & 35 & 43 & 53 & 35 & 20 & 29 & 7 & 9 & 8 \\
\hline Steak House & & & & & 2 & & & & & \\
\hline Churrascaria Rodízio & & & & & & & & 9 & 11 & 13 \\
\hline Argentino & & & & 1 & & & & 1 & 6 & 8 \\
\hline Parrilada & & & & & & & & 3 & & \\
\hline Uruguaia & & & & & & & & & 1 & 1 \\
\hline Pescados & & 2 & 5 & 11 & 11 & 10 & 12 & 7 & 5 & 3 \\
\hline Contemporânea & & & & & & & & & 11 & 13 \\
\hline $\begin{array}{l}\text { Variada } \\
\text { Variada Bufê }\end{array}$ & & & & & & 28 & 38 & 36 & 33 & $\begin{array}{l}42 \\
11\end{array}$ \\
\hline Internacional & 35 & 40 & 19 & 54 & 27 & & & & & \\
\hline Italiana & 33 & 51 & 55 & 97 & 64 & 47 & 62 & 39 & 37 & 41 \\
\hline Italiana Cantina & & & & & & & & 19 & 17 & 14 \\
\hline Pizzarias & & 0 & 43 & 69 & 36 & 13 & 18 & 17 & 23 & 19 \\
\hline Francesa & & & 14 & 18 & 25 & 24 & 24 & 23 & 16 & 24 \\
\hline Franceses e Suíços & 9 & 18 & & & & & & & & \\
\hline Suíça & & & 3 & 3 & 4 & 3 & 3 & 2 & 1 & 1 \\
\hline Portuguesa & 5 & 4 & 5 & 8 & 9 & 3 & 6 & 5 & 5 & 7 \\
\hline Espanhola & & 2 & 3 & 10 & 8 & 6 & 11 & 10 & 6 & 4 \\
\hline Alemã & & & 9 & 13 & 12 & 7 & 4 & 5 & 4 & 4 \\
\hline Alemã e Cervejaria & & 14 & & & & & & & & \\
\hline Alemã e Austríacos & 9 & & & & & & & & & \\
\hline Austríaca & & & & 2 & 1 & & & & & \\
\hline Japonesa & 5 & 5 & 8 & 18 & 20 & 17 & 20 & 25 & 26 & 23 \\
\hline Asiática & & & & & & & & & 2 & 1 \\
\hline Chinesa & 3 & 8 & 20 & 49 & 19 & 11 & 9 & 8 & 6 & 5 \\
\hline Coreana & & & & 2 & 1 & 1 & 1 & & & 3 \\
\hline Indiana & & & & & 2 & 1 & 3 & 1 & 2 & \\
\hline Indonésia & & & & 1 & & & & & & \\
\hline Tailandesa & & & & & & & 1 & 1 & 1 & \\
\hline Árabe & 4 & 3 & 6 & 10 & 10 & 5 & 9 & 12 & 9 & 11 \\
\hline Israelita & 2 & & & & & & & & & \\
\hline Grega & & & & 1 & 1 & 2 & 1 & 1 & 1 & \\
\hline Judaica & & & & 1 & 2 & 2 & 4 & 3 & 2 & 1 \\
\hline Marroquina & & & & & & & & & 2 & 1 \\
\hline Turca & & & & & & & & & & 1 \\
\hline Boliviana & & & & 2 & & & & & & \\
\hline Peruana & & & & & & & & & & 2 \\
\hline Escandinava & 2 & 1 & & 2 & 1 & 1 & 2 & & & \\
\hline Húngara & 1 & 1 & & 5 & 2 & 1 & & & & \\
\hline Russa & 1 & 2 & & 1 & 1 & 1 & & & & \\
\hline Mexicana & & & & 1 & 1 & & & & 1 & 1 \\
\hline Norte Americana & & & & & & 1 & & & & \\
\hline Vegetariana & 1 & 1 & & 8 & 5 & 2 & 2 & 2 & 5 & 5 \\
\hline Macrobiótica & & 1 & & 2 & 2 & 2 & & & & \\
\hline Natural & & & & 1 & 4 & 1 & 1 & & & \\
\hline Saladas & & & & & 3 & & 1 & & & \\
\hline Cozinha Rápida & & & & & & & 10 & 6 & 8 & \\
\hline Sanduíches & & & & & 7 & 9 & & & & \\
\hline Panqueca & & & & 2 & 6 & & & & & \\
\hline Queijos e Vinhos & & 2 & 3 & 4 & 2 & 1 & 1 & & & \\
\hline Outros & & 2 & 37 & & & & & & & \\
\hline TOTAL & 131 & 200 & 283 & 469 & 335 & 225 & 283 & 257 & 267 & 285 \\
\hline
\end{tabular}

Fonte: Elaborado pela autora (GUIA QUATRO RODAS, 1965; 1971; 1975, 1980; 1985; $1989 ; 1995 ; 2000 ; 2005 ; 2010)$. 
Acompanhando os 45 anos desse Guia, é possível perceber o dinamismo do mercado de alimentação na cidade, inclusive com categorias que surgem ou são excluídas em diferentes edições, destacando, também, as mudanças que ocorrem ao longo do tempo.

Com base na Tabela 18, que indica o número de restaurantes listados em cada categoria em distintas edições do Guia 4 Rodas, é possível notar, depois da abertura das importações na década de 1990, por exemplo, o desaparecimento da categoria cozinha internacional, até então bastante representativa dentro da sua seleção. Paralelamente, vê-se surgir uma categoria identificada como variada e, alguns anos mais tarde, os restaurantes ditos contemporâneos.

A cozinha italiana manteve sua importância representada no Guia ao longo do tempo na cidade e, com o passar dos anos, os restaurantes italianos passaram a ser divididos em subcategorias, distinguindo-os das cantinas e das pizzarias, reflexo do número crescente de estabelecimentos com diferentes características em São Paulo e da sofisticação de alguns deles.

Já a partir da década de 1980, nota-se um aumento significativo da participação de restaurantes japoneses apontando para uma maior aceitação desse tipo de cozinha na cidade.

Por outro lado, a cozinha brasileira vem apresentando mudança recente no tratamento, pois passou a ter a subdivisão referente às respectivas cozinhas regionais.

Importante também perceber como ao longo das últimas cinco décadas a localização dos restaurantes mais destacados pela imprensa foi seguindo a expansão da área nobre da cidade. Saiu da região mais central, seguiu em direção à área denominada Jardins e, nos últimos anos, rumou para o entorno do eixo da Av. Brigadeiro Faria Lima (Figuras 8 e 9), permitindo entrever a importância da localização das atividades varejistas e de serviços, tema este tratado em profundidade nos trabalhos de Masano $(1984 ; 1993)$. 


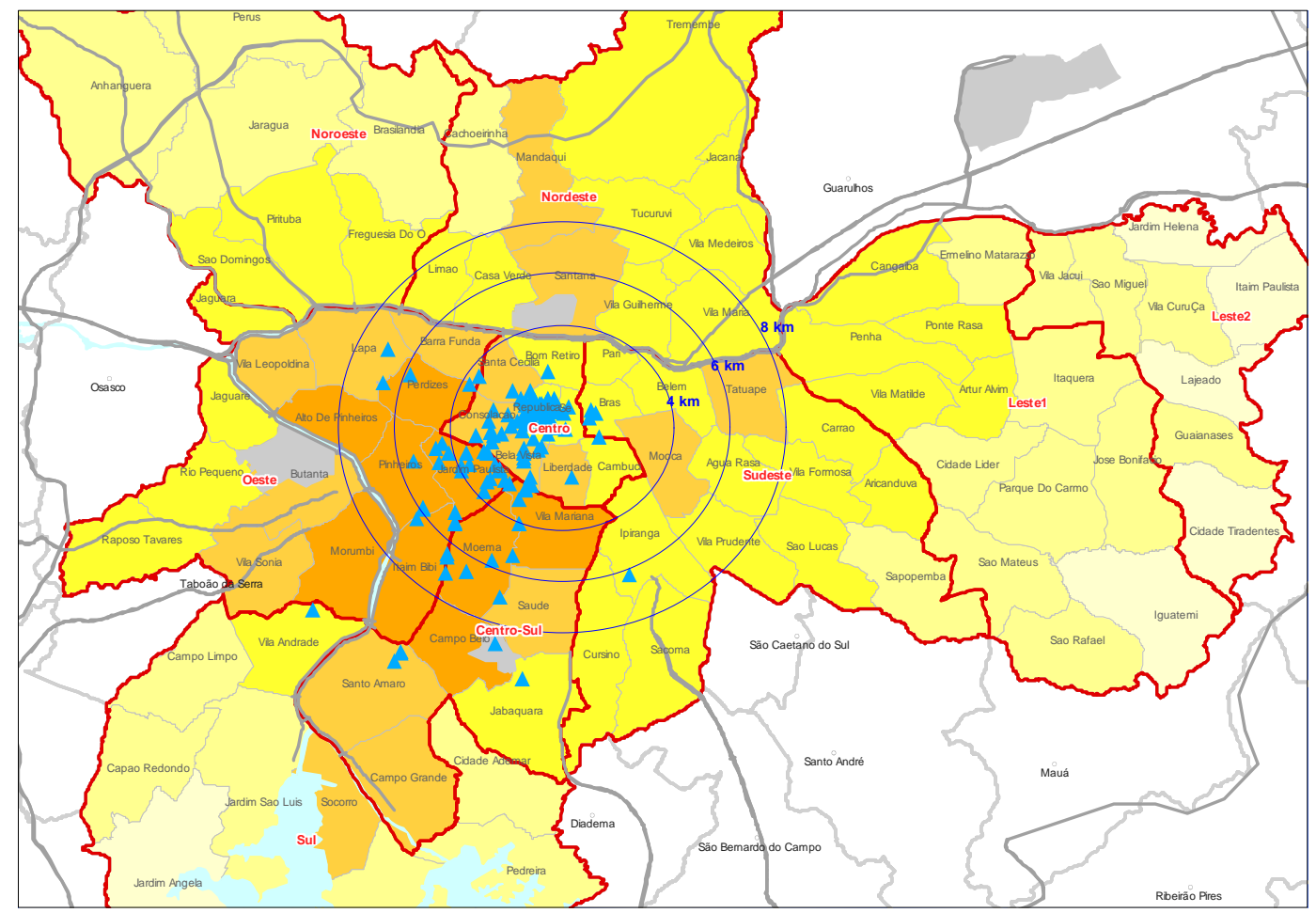

Figura 8: Restaurantes (131) da 1e edição do Guia 4 Rodas (1966)

Fonte: Elaborado pela autora (GUIA QUATRO RODAS, 1965).

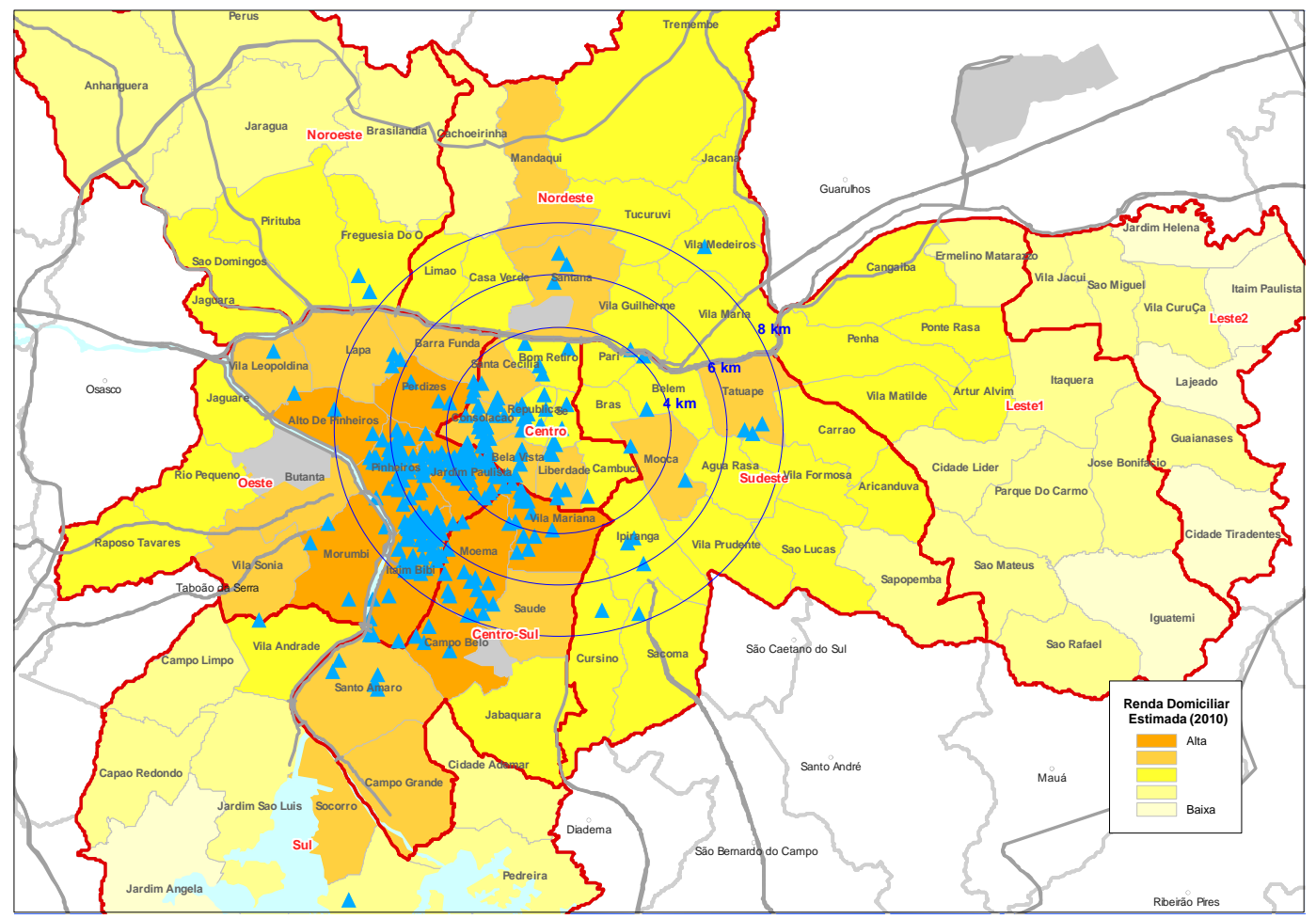

Figura 9: Restaurantes (363) da última edição do Guia 4 Rodas (2011)

Fonte: Elaborado pela autora (GUIA QUATRO RODAS, 2010). 
Com o intuito de melhor compreender a oferta gastronômica que caracteriza São Paulo como o principal polo gastronômico nacional, no próximo capítulo são descritos os resultados da pesquisa de campo realizada com os chefs e proprietários de restaurantes e jornalistas especializados, apresentando-se entendimentos e percepções desses grupos com relação à gastronomia na cidade. 


\section{APRESENTAÇÃO DOS RESULTADOS DA PESQUISA}

Por intermédio de entrevistas realizadas com chefs e proprietários de restaurantes e jornalistas especializados em gastronomia, foram colhidas uma série de observações, entendimentos e reflexões sobre $o$ momento atual e as transformações pelas quais vem passando o mercado de alimentação e mais especificamente de restaurantes na cidade de São Paulo.

Tais opiniões e percepções serão apresentadas separadamente para os dois públicos entrevistados - chefs e proprietários de restaurantes e profissionais da mídia especializada -, para que se possa compará-las, seguindo uma mesma estrutura, organizada em três temas:

No primeiro - Mudanças no mercado de alimentação na cidade de São Paulo -, são destacadas as transformações percebidas nesse mercado no âmbito dos ingredientes e produtos, assim como dos consumidores, dos estabelecimentos, e ainda da atuação da mídia especializada.

No segundo - São Paulo Cosmopolita -, é feita a caracterização da oferta de restaurantes em São Paulo, proposta uma análise sobre as diferenças e similitudes entre o que é ofertado nos restaurantes paulistanos e em outros países, abordandose também a questão da globalização.

Já o terceiro - São Paulo, Brasil -, destina-se a tratar mais especificamente da cidade de São Paulo enquanto parte do Brasil, sendo levantadas questões referentes à comida brasileira e à "valorização da gastronomia brasileira", discutindose ainda a relação local versus global em São Paulo a partir dessa perspectiva. 


\subsection{Profissionais da mídia especializada}

\subsubsection{Mudanças no mercado de alimentação na cidade de São Paulo}

Entre os profissionais da mídia especializada, a abertura de importações ocorrida no governo Collor ecoa em uníssono como um expressivo elemento de transformação do mercado de alimentação em São Paulo nos últimos anos, sendo referida ainda como responsável pelo amadurecimento dessa área.

As mudanças desencadeadas com a abertura das importações vão ter impacto em diversas esferas desse mercado, podendo ser observadas no que se refere à disponibilidade de ingredientes e produtos, no âmbito dos consumidores, no que é oferecido pelo restaurante, refletindo-se, inclusive, na atuação da mídia especializada.

\subsubsection{Ingredientes e Produtos}

Os entrevistados são unânimes ao apontar a importância exercida pela abertura das importações, ocorrida na década de 1990, como o grande ícone de transformação no tocante a ingredientes e produtos disponíveis no mercado paulistano, sendo reforçada pelo Plano Real.

Esse movimento corresponderia não só a um movimento na quantidade de produtos disponíveis, mas também a uma melhora na qualidade dos mesmos, que vai se refletir ainda no mercado interno.

Quando questionados sobre as mudanças observadas neste contexto, todos os entrevistados elegeram a abertura de mercado como o primeiro e principal fator, caracterizando tal evento como um "boom" (Castanho- Guia Quatro Rodas ; Castilho - Prazeres da Mesa), uma "avalanche" (Castanho (Guia Quatro Rodas) ou como um "marco" (Lopes - Gosto e O Estado de São Paulo) na trajetória da alimentação na cidade de São Paulo.

Muitos exemplos no que se refere ao acesso a produtos foram citados pelos entrevistados, ressaltando que o que antes não era encontrado na cidade ou era 
acessível apenas a consumidores de elevado poder se tornaram mais amplamente disponíveis. Lembram ainda que até a década de 1990, muitos produtos só chegavam na cidade quando alguém trazia de uma viagem ao exterior.

Camargo (O Estado de São Paulo) pontua dois momentos que considera marcantes: a abertura das importações em 1990 e a fase do dólar a um para um no Plano Real. Segundo ele, a partir daí, "a gente pôde comprar mais produtos importados, a gente teve acesso a muita coisa que foi importante na formação do Brasil".

Lorençato (Veja São Paulo) contextualiza essa abertura como uma volta dos ingredientes depois de um período de protecionismo da indústria nacional, imposto durante o regime militar: "há um momento que é muito importante, a entrada dos ingredientes, a volta desses ingredientes. (...) Até 1990, champignon enlatado, o cogumelo de Paris, era chique, você pega o petit-pois ou ervilha... era chique na alimentação".

Ele destaca, ainda, que até esse período alguns chefs supervalorizavam ingredientes que traziam de suas viagens ao exterior e que ainda não eram conhecidos no Brasil. "Você não tem internet, você não tem nada... Ele [ o chef] faz uma viagem pra Tailândia, traz algumas especiarias que você não conhece, então ele fala com você... Parece que é algo miraculoso(...). Era uma coisa muito comum, as pessoas traziam pequenas quantidades na mala, ainda não tinha na Liberdade aquilo que você acha hoje, então se tem aí essa febre da descoberta".

A entrada de produtos provocou a alteração na forma de preparar algumas receitas na cidade que haviam sido adaptadas a produtos nacionais. Dois dos entrevistados citam o risoto como uma referência que teve sua composição alterada quando a arroz arbóreo passou a ser importado da Itália. Lopes (Gosto e O Estado de São Paulo) ressalta que "os risotos aqui antes da abertura de importações eram feitos com o arroz brasileiro, arroz agulhinha (...)" e Castanho (Guia Quatro Rodas) lembra e compara o arroz de forno da sua infância - chamado de risoto - com os risotos da atualidade, duas preparações completamente diferentes, no seu entender.

Castanho (Guia Quatro Rodas) salienta ainda, que, concomitantemente ao despontar dos ingredientes importados, cresceu o acesso a ingredientes frescos com o Plano Real, afirmando: "a abertura das importações na era Collor deu um boom para o setor, porque permitiu essa facilidade, ingredientes importados, e ao 
mesmo tempo também você conseguia ter um acesso mais fácil a ingredientes frescos".

Decorrente ainda da entrada de novos produtos no mercado, parte dos entrevistados aponta uma mudança no que concerne aos produtos nacionais, que frente à concorrência, são exigidos a incrementar a qualidade.

Castilho (Prazeres da Mesa) confere também à abertura das importações um fato de extrema relevância, afirmando que os seus 26 anos de atuação na área podem ser divididos em dois momentos: antes e depois dela. Ele ressalta ainda modificações relevantes que transcorreram no mercado interno em decorrência dessa abertura e que atuaram como fator de pressão para que o mercado nacional melhorasse a qualidade do que era produzido. Ele diz que "depois que os consumidores têm acesso a produtos importados - de melhor qualidade - eles não vão mais querer consumir outros piores".

llustrando esse movimento, dois exemplos citados por ele são o mercado de vinho e o de massa, para os quais considera que houve expressivo salto qualitativo: "hoje há pelo menos 20 marcas de vinhos brasileiros que se consegue tomar sem nenhum problema; coisa que há 15 anos não tinha. (...) Se você pegar a massa, por exemplo... a massa que fazem hoje é muito melhor do que se fazia há dez anos".

Em adição ao exposto, alguns dos entrevistados disseram perceber também um movimento recente no sentido de falar mais do ingrediente brasileiro a fim de que sejam mais utilizados. Nesse sentido, Castilho (Prazeres da Mesa), embora esteja entre eles, afirma considerar tal comportamento uma realidade ainda distante.

\subsubsection{O Consumidor}

Todos os entrevistados pontuam que a década de 1990 marca ainda a ampliação do mercado consumidor na cidade de São Paulo. Há o entendimento de que um maior número de pessoas passa a ter acesso a diferentes ingredientes e a restaurantes.

Paralelamente verifica-se que o consumidor torna-se mais informado e que se eleva seu nível de exigência, o que decorre tanto do incremento da oferta na cidade quanto da maior facilidade em viajar, que permitem a esse consumidor adquirir novas referências gastronômicas. 
De acordo com Lorençato (Veja São Paulo), depois das mudanças transcorridas com relação a ingredientes e produtos, "o segundo grande acontecimento [dentre as transformações do mercado de alimentação em São Paulo] é a migração da classe média para a cozinha." Camargo (O Estado de São Paulo), compartilhando dessa visão, afirma: "a partir daí se criou um mercado consumidor de classe média um pouco mais consistente".

Para os entrevistados, ao mesmo tempo em que se amplia o mercado, o consumidor torna-se mais bem informado e mais exigente. É o que explicita Castilho (Prazeres da Mesa), ao dizer: "ele [o consumidor] não aceita mais qualquer produto como era antigamente".

Complementarmente, Lopes (Gosto e O Estado de São Paulo) acrescenta que os brasileiros passaram a viajar mais para o exterior e com isso passaram também a ter outras referências. Essa visão é também pontuada por Melo (Guia Josimar e Folha de São Paulo): "os consumidores passam a viajar cada vez mais e conhecem de perto um outro patamar de produtos e serviços".

Ilustrando a mudança ocorrida do ponto de vista do conhecimento do leitor sobre gastronomia, Lopes (Gosto e O Estado de São Paulo) recorda-se das primeiras cartas que recebeu, quando começou na revista Gula, em 1991. Eram leitores curiosos em saber o que era a massa penne, hoje tão popular, ou preocupados em contrair alguma doença caso ingerissem foie gras, que havia sido tema de uma matéria detalhada na revista. "Hoje, ninguém perguntaria isso", afirma ele.

\section{$\underline{5.1 .1 .30}$ restaurante}

Entre as diversas questões a respeito das mudanças que transcorrem nos restaurantes, sobressai a ideia de uma melhora na qualidade do que é ofertado ao cliente. Para os entrevistados, a maior oferta de ingredientes e produtos e a exigência crescente por parte dos consumidores refletem-se nesses estabelecimentos.

Castilho (Prazeres da Mesa) aponta um crescimento quantitativo e qualitativo da oferta de restaurantes em São Paulo depois da abertura das importações, sendo acompanhado, entre outros aspectos, por um maior interesse pelo tema gastronomia, e pelo crescimento da oferta de cursos na área. 
Camargo (O Estado de São Paulo) também descreve um processo de crescimento e amadurecimento conjunto do mercado, enquanto Lopes (Gosto e 0 Estado de São Paulo) aponta para a qualificação da oferta, inclusive de restaurantes tradicionais da cidade. Castanho (Guia Quatro Rodas) compartilha tal visão afirmando que "a oferta de restaurantes foi modificada por causa do grau de exigência, com a elevação do grau de exigência do consumidor".

Os profissionais entrevistados afirmam que a entrada de novos produtos no mercado viabilizou o estabelecimento de novas cozinhas na cidade e aguçou 0 interesse dos consumidores para a descoberta de novos sabores.

Nesse contexto, Lorençato (Veja São Paulo), ao propor uma análise histórica, destaca mudanças visíveis nos restaurantes de São Paulo antes e depois da década de 1990 e ressalta: "num determinado momento todos os restaurantes têm pratos muito semelhantes, então você tem um reinado da cozinha internacional." Ainda fazendo referência às especialidades gastronômicas em destaque na cidade descreve o nascimento da cozinha contemporânea no Brasil como decorrência da entrada de uma série de ingredientes nos mercados da capital paulista.

Do ponto de vista estrutural e administrativo notam-se mudanças que indicam maior profissionalização do setor, tendo sido destacados especialmente aspectos associados ao gerenciamento de estoque, à qualificação da mão de obra e ao maior emprego de produtos frescos. Castanho (Guia Quatro Rodas) explica: "eu acho que acabou certo comodismo dos restaurantes de ter tudo estocado. Antes do Plano Real, eu imagino que os restaurantes faziam como a gente fazia em casa, estocavam alimento... e hoje não".

Nesta linha, Melo (Guia Josimar e Folha de São Paulo) destaca a profissionalização do meio, com uma mão de obra mais qualificada e com experiência mais ampla, salientando também a participação desses profissionais no contexto internacional: "são profissionais mais cultos, que conhecem produtos de fora e que acompanham tendências internacionais".

\subsubsection{A mídia especializada}

A respeito do trabalho da mídia especializada, os entrevistados sustentam que ela acompanhou 0 desenvolvimento e 0 amadurecimento do mercado paulistano. A maioria dos entrevistados reafirma que o tema gastronomia vem 
ganhando maior destaque nos meios de comunicação, haja vista o crescimento do número de publicações na área e o aumento do espaço dedicado à gastronomia em diferentes mídias: revista, jornal, guia, televisão, internet.

Lopes (Gosto e O Estado de São Paulo), ao relatar que a imprensa acompanha uma qualificação da cozinha no Brasil, destaca: "a imprensa hoje... você tem um leque de publicações, cadernos especiais, isso não existia”. Melo (Guia Josimar e Folha de São Paulo) concorda, mas pondera, ao avaliar que outras vertentes do cenário de gastronomia evoluíram de maneira mais rápida: "a mídia acompanhou este processo evolutivo do mercado, embora de uma maneira mais lenta. Há 20 anos só havia uma revista, que era a Gourmet, que acabou; a mídia só tratava a cozinha como culinária, como receita".

Fazendo uma leitura da atuação da mídia e destacando particularidades dos seus respectivos trabalhos, todos os entrevistados concordam em que há um novo tratamento do tema, mais consistente, amplo e profundo.

Lorençato (Veja São Paulo) explicita, por meio de sua própria trajetória na revista Veja São Paulo o crescente destaque que a gastronomia vem recebendo em publicações, em virtude do crescimento do mercado e do maior interesse despertado pelo tema na atualidade. Menciona que seu retorno para a revista, em 2005, correspondeu justamente a uma necessidade da mesma em dispor de um editor que estivesse dedicado exclusivamente ao assunto.

Nesse sentido, Castanho (Guia Quatro Rodas) revela que "o Guia [Quatro Rodas] acompanhou o desenvolvimento do paladar [em São Paulo]. Ao mesmo tempo em que os restaurantes foram se profissionalizando, o Guia também criou mecanismos e teve referências melhores. O Guia mudou junto com o público, a partir do momento que você tem outros referenciais de qualidade; o grau de exigência dos avaliadores do Guia e do público também aumentou".

Camargo (O Estado de São Paulo) frisa que a mídia não faz parte do meio gastronômico e sim "cobre o meio". Entende ainda que a mídia acompanha o processo de crescimento, qualificação e amadurecimento da gastronomia em São Paulo, visão que é compartilhada com todos os seus colegas entrevistados. Destaca a chegada do Caderno Paladar, em 2005, como uma demonstração de maturidade e uma caracterização do crescimento do público interessado em consumir informação sobre gastronomia. 
Interessante destacar que todos os entrevistados, contudo, fazem alguma crítica ao meio jornalístico. Para Lorençato (Veja São Paulo), "a imprensa ajuda a cristalizar algumas coisas que não são reais, mitos da cidade".

Castanho (Guia Quatro Rodas) e Castilho (Prazeres da Mesa) conferem certo elitismo à mídia, ao destacar que esta concentra sua atuação em uma parcela restrita do mercado, apoiando a criação de determinados padrões. "Atualmente, se o chocolate não tiver $90 \%$ de cacau de origem não é bom, o tomate também deve ser de origem, o azeite precisa necessariamente ter o mínimo de acidez, o café, tirado por um barista, entre outras exigências que vão sendo impostas", destaca Castilho (Prazeres da Mesa). Nesse sentido, Camargo (O Estado de São Paulo) complementa: "a mídia vem ampliando os horizontes, mas ainda se fala muito nos mesmos nomes".

\subsubsection{São Paulo Cosmopolita}

Quando se trata de caracterizar a cidade de São Paulo e especialmente sua oferta gastronômica, o adjetivo "cosmopolita" é utilizado pela maioria dos entrevistados. Assim, acompanhada de questões como a magnitude da oferta e o maior profissionalismo encontrado em São Paulo, a diversidade e a multiculturalidade foram os temas de destaque entre os entrevistados ao tratarem da oferta de restaurantes da cidade.

Foi ainda explorada a correspondência entre o que é ofertado em São Paulo e os locais de origem de algumas cozinhas (no caso dos restaurantes étnicos) e traçadas algumas ponderações sobre os reflexos da globalização no mercado de alimentação da cidade.

\subsubsection{A oferta de restaurantes em São Paulo na atualidade}

A oferta de restaurantes em São Paulo é apontada como a maior, melhor e mais importante do país por todos os entrevistados. Entendida como única e como referência no país, a gastronomia paulistana é considerada, inclusive, por alguns dos entrevistados uma das mais diversificadas e qualificadas do mundo. 
Castanho (Guia Quatro Rodas) destaca que a oferta paulistana é referência para avaliar os restaurantes de todo o Brasil: "é a melhor oferta disparada do país, eu acho que aqui a gente tem várias especialidades de excelência, que eu chamo de referência para avaliar restaurantes similares em todo país".

Na mesma linha, Melo (Guia Josimar e Folha de São Paulo) caracteriza a oferta de restaurantes em São Paulo como "muito boa e generosa pela variedade das cozinhas representadas e também pelos padrões dos restaurantes. (...) São Paulo é uma cidade de braços abertos para outras culturas e o cenário gastronômico reflete isso".

"A identidade de São Paulo é cosmopolita", afirma Lopes (Gosto e O Estado de São Paulo). Castilho (Prazeres da Mesa) é entusiasta ao descrever a oferta gastronômica de São Paulo, uma vez que exclama que a cidade "reúne de tudo, poucos lugares do mundo têm essa oferta que São Paulo tem hoje." A excelente qualidade e a diversidade da oferta paulistana ressaltadas por ele é compartilhada pelos colegas, embora com algumas ressalvas.

Camargo (O Estado de São Paulo) concorda com a expressiva variedade de São Paulo e afirma que até o Rio de Janeiro transforma-se em uma cidade pequena quando comparada à capital paulista que, para ele, está muito à frente de várias cidades, como por exemplo, Buenos Aires. Ele menciona, no entanto, que a oferta de restaurantes de algumas nacionalidades em São Paulo é restrita, citando como exemplo as cozinhas asiáticas, e reforça que em Londres se encontram restaurantes representantes de cerca de 140 etnias, enquanto em São Paulo tal número gira em torno de 50 hoje em dia.

Nesse contexto, Lorençato (Veja São Paulo) salienta ainda a existência de poucos restaurantes portugueses e mesmo brasileiros em São Paulo, realçando, em contraposição, a predominância de restaurantes italianos e japoneses: "tem dois ramos muito fortes na culinária paulistana, uma é italiana e a outra é japonesa; [como elas] não há nenhuma outra". Ainda assim, e apesar de haver, segundo ele, restaurantes japoneses "esplêndidos", remarca que se concentram em oferecer sushi e sashimi.

Nesse sentido, Lopes (Gosto e O Estado de São Paulo) ainda contrapõe o cosmopolitismo da oferta paulistana, porquanto não haja na cidade um restaurante de comida paulista; e complementa a questão, afirmando: “agora em São Paulo há 
grandes restaurantes de cozinha brasileira. Mas é bom dizer que isso é um fenômeno recente. Até há pouco tempo tínhamos vergonha da nossa cozinha”.

\subsubsection{O restaurante "aqui" e "lá"}

Outro assunto tratado com os entrevistados versou sobre as adaptações feitas em São Paulo, com a intenção de entender qual a correspondência entre a oferta que se constitui como cosmopolita, multicultural e o que se oferece nos países que originam essa cozinha.

Todos os entrevistados enxergam haver na oferta de restaurantes de São Paulo, em algum grau, uma adaptação quando se contrapõe o restaurante instalado na cidade versus o restaurante instalado em seu país de origem. Os assuntos mais abordados pelos entrevistados neste contexto associam-se ao reducionismo da oferta e à alteração nas formas de preparo.

É entendido pelos entrevistados que São Paulo oferece uma culinária multicultural que assume contornos próprios. Os restaurantes étnicos, representantes de cozinhas de várias partes do mundo, apresentam na cidade de São Paulo um mix de receitas trazidas de fora que sofreram influências locais, advindas de diferentes razões. Importante destacar que a adaptação e até a restrição da cozinha são entendidas como naturais, fruto de influencia e miscigenação de culturas.

Algumas cozinhas ficam, para alguns dos entrevistados, restritas a poucos pratos ou variações, enquanto outras se expressam de forma mais ampla.

Lorençato (Veja São Paulo) ao tratar do tema faz uma distinção. Para ele, uma coisa é a oferta que é fruto de contribuições imigrantes, ou seja, o recorte do imigrante é o espelhamento da matriz em dado momento, uma vez que o imigrante tenta reproduzir aquilo que comia em sua terra natal; antes era um retrato congelado daquela cultura e atualmente tem evoluído, tem mudado, em razão da facilidade de viajar e trazer novas referências. Outra é aquela que surge pelas mãos de alguém que não faz parte daquela cultura, mas que vai até um lugar, prova alguns pratos e faz um "instantâneo daquilo", replicando o que foi capaz de apreender, propondo algo "que beira quase à caricatura". 
Castanho (Guia Quatro Rodas), apesar de destacar a variedade paulistana, aponta um "abrasileiramento" e um "reducionismo de oferta". Assim como outros entrevistados, ele cita o fato de a cozinha portuguesa restringir-se muitas vezes ao bacalhau, a cozinha espanhola à paella e a cozinha japonesa ao sushi e ao sashimi.

Para Castanho (Guia Quatro Rodas), o que sucede é que quando algum prato cai no gosto paulistano, é aproveitado comercialmente à exaustão: "em São Paulo, a gente tem muito reducionismo de oferta em relação àquilo que a gente poderia ter, e pouca gente preocupada em aumentar os horizontes (...). Mesmo no melhor polo gastronômico do país, a gente acaba dando uma visão muito limitada." Lopes (Gosto e $O$ Estado de São Paulo) considera natural que haja uma adaptação: "se você tem uma clientela diferente você tem que adaptar".

Pode-se mencionar ainda as particularidades da oferta de comida japonesa em São Paulo que, segundo Lorençato (Veja São Paulo), foi bastante influenciada pelos Estados Unidos. Pode-se citar também o caso das cantinas que, de acordo com Castanho (Guia Quatro Rodas), apesar de serem classificadas como italianas, apresentam um receituário próprio, composto por pratos que foram, em grande medida, concebidos "no seu interior", isto é, na própria cidade de São Paulo.

\subsubsection{Globalização}

Os entrevistados enfocaram majoritariamente os aspectos positivos da globalização, destacando a riqueza dos intercâmbios culturais, a ampliação do conhecimento e a valorização da diversidade frente à tendência de uniformização do mercado.

A padronização, uma vertente da globalização também apontada nas entrevistas, foi tratada sob uma dupla ótica. Se por um lado ocorre, em algum grau, a estandardização das ofertas, observa-se em paralelo a busca e a valorização de movimentos exatamente contrários, que valorizam o singular e o regional.

Melo (Guia Josimar e Folha de São Paulo) trata da globalização como um paradoxo: "a globalização tende a equalizar o gosto como um todo, não apenas a comida. (...) A chegada do McDonald's é tão acintosa que, paradoxalmente, as culturas locais estão se valorizando; existe uma revalorização dos gostos locais". 
Castilho (Prazeres da Mesa) enfoca a questão associada aos intercâmbios, afirmando que a globalização permite a ampliação do conhecimento e das discussões. Lopes (Gosto e 0 Estado de São Paulo) expõe ainda que, durante algum tempo, acreditou-se que o fast food iria dominar o mercado de alimentação no mundo e pondera: "isso não aconteceu. Ao contrário, o que se percebe é uma valorização das cozinhas regionais como contrapartida".

Camargo (O Estado de São Paulo) assegura que alguma forma de padronização é inevitável, do mesmo modo que uma uniformização do gosto, fazendo referência à criação de comunidades dispersas e reconhecendo-se como integrante de uma comunidade urbana cosmopolita. Entretanto afirma que, se por um lado a globalização é preocupante, não devemos, contudo, ter medo de nos organizarmos supranacionalmente. Quanto ao Brasil, destaca que o país tem muitas particularidades a se proteger, tais como a significativa diversidade de biomas e a própria língua portuguesa.

\subsubsection{São Paulo, Brasil}

A cidade de São Paulo é considerada, sob qualquer visão, o principal polo gastronômico do país. Definir "comida brasileira", contextualizá-la versus a oferta observada na mesa paulistana, avaliar movimentos associados à "valorização da gastronomia brasileira" e discutir "o local e global" na cidade de São Paulo são temas que abriram uma série de reflexões por parte dos entrevistados.

Pode-se adiantar que a pluralidade, a diversidade, a adaptação e o dinamismo são as características mais fortemente exploradas quando se aborda 0 tema comida, cozinha, culinária ou gastronomia brasileira (termos, no mais das vezes, utilizados como sinônimos pelos entrevistados). 


\subsubsection{A comida brasileira e a mesa paulistana}

Definir o que é comida brasileira e estabelecer a relação entre esta e a mesa paulistana não foi simples para os entrevistados. O tema "comida brasileira" revelouse complexo, de modo que é a pluralidade o ponto de convergência das expressões.

"Cozinhas brasileiras" por Camargo (O Estado de São Paulo), "colcha de retalhos" por Castilho (Prazeres da Mesa) e "mosaico" por Lopes (Gosto e 0 Estado de São Paulo) foram expressões utilizadas na tentativa de expressar a comida brasileira.

A culinária brasileira foi caracterizada com a exemplificação de elementos distintos pelos entrevistados, passando por influências na formação da população, diversidade de biomas e de ingredientes, receitas e formas de preparo.

Nesse sentido, Lorençato (Veja São Paulo) afirma que "a culinária brasileira tem muitas faces" e se indaga de que modo seria possível definir algo tão diversificado, visto que "se citássemos somente a Bahia já seria preciso fazer a distinção entre a comida do Recôncavo e a do sertão, que predomina no Nordeste". Pontuando diversas diferenças regionais, ele questiona novamente: "Como definir algo tão rico?".

Na mesma linha, Camargo (O Estado de São Paulo) chama atenção para a diversidade de biomas existentes no país, afirmando tratarem-se de "cozinhas brasileiras", no plural, que "vão variar conforme a situação geográfica, a disponibilidade de produtos e a cultura local que produziu interferências naquele produto".

De forma também grandiosa, Lopes (Gosto e O Estado de São Paulo) caracteriza comida brasileira como "um grande mosaico, com coisas até desconhecidas da gente e que tem a cozinha luso-brasileira como coluna vertebral". Castilho (Prazeres da Mesa) usa a expressão "colcha de retalhos"e destaca alguns "modos de preparo", como a cultura do forno à lenha e da panela de barro, sobrepondo-os à origem dos ingredientes.

Em sintonia, Castanho (Guia Quatro Rodas) defende que a comida brasileira é uma mistura que reflete a colonização e os hábitos incorporados pela população em sua alimentação. A partir daí, aponta a macarronada e o filé à milanesa ou à parmegiana como expressões da comida paulistana, visão compartilhada por outros (dois) entrevistados. 
Nessa direção, Camargo (O Estado de São Paulo) afirma que não é porque em lugares como Belém ou Recôncavo Baiano a presença de uma cozinha local é muito mais evidente, ou porque em São Paulo a comida do cotidiano inclui lasanha, picadinho, feijoada e bacalhau que esta deve ser considerada menos brasileira. "Sou um brasileiro urbano (...). É natural em São Paulo a gente ter mais fresca na memória a cozinha dos imigrantes, que é nossa também (...). Nosso estômago é grande o suficiente para englobar tudo isso, acho que hoje estrogonofe também é cozinha paulista se você for pensar...".

Corroborando tal ideia, Lorençato (Veja São Paulo) afirma que a culinária brasileira tem a característica de incorporar alguns processos de produção, um "fazer à sua maneira. Aí até dizer que é italiano algo que não é ou que é japonês algo que não é. (...) O sushi de salmão é japonês? Não é, é tipicamente brasileiro".

\subsubsection{2 "Valorização da Gastronomia Brasileira"}

Há consenso entre os entrevistados de que a expressão "valorização da gastronomia brasileira" tem sido amplamente veiculada na mídia recentemente. Embora a expressão em si não seja apreciada por todos, há unanimidade em reconhecer um movimento que busca destacar e valorizar a comida brasileira nos últimos anos.

Riqueza e diversidade, em especial para destacar singularidades regionais do Brasil, são termos novamente proferidos pelos entrevistados. Os movimentos associados à valorização da comida, da cozinha ou da gastronomia têm sob a ótica dos entrevistados o objetivo primeiro de levar aos mercados e à mesa uma maior variedade de produtos e preparos nacionais.

A maioria dos entrevistados expressa notar a vontade de alguns agentes envolvidos no cenário de alimentação no Brasil (foram citados jornalistas, chefs, produtores e historiadores) em amplificar a expressão da cozinha brasileira.

Os entrevistados atribuem estes movimentos ao amadurecimento de que 0 Brasil possui uma identidade ainda escondida ou distante da maioria e que deve ser mostrada, compartilhada e reconhecida. Existem, contudo, diferentes visões sobre a intensidade e o estágio das ações associadas à valorização da gastronomia brasileira. 
A cidade de São Paulo é entendida como o principal centro impulsionador e difusor de tais movimentos, embora um dos entrevistados pontue que, em função da expressão das cozinhas regionais, é possível que outros locais se destaquem em relação a São Paulo no curso do tempo.

Melo (Guia Josimar e Folha de São Paulo) afirma estar acontecendo um movimento de valorização da gastronomia brasileira, que contempla resgate e criação: "há movimentos para recuperar e executar receitas tradicionais, embora com técnicas e equipamentos modernos. (...) Existem também aqueles que querem uma cozinha própria, usando sabores que a gente encontra no Brasil, uma cozinha Bossa Nova, como aconteceu com a música".

Segundo Camargo (O Estado de São Paulo), "a gente tem percebido que existe uma cozinha brasileira que tem que ser reconhecida e identificada. E é uma cozinha que está em vias de se transformar em gastronomia. Quer dizer, é preciso que haja identificação de cozinhas regionais, produtos regionais, qualificação de técnica, ensinamento de técnica, até que se crie um repertório nacional. Com uma notação reconhecível, com uma sintaxe conhecível, uma linguagem conhecível".

Para Lorençato (Veja São Paulo), o momento atual corresponde a uma retomada do nacional após um período de negação, decorrente do regime militar. $\mathrm{O}$ que ocorre é uma difusão da gastronomia brasileira, já que se tem acesso a produtos até então desconhecidos, além do reconhecimento de um patrimônio imaterial.

Nesse sentido, Castanho (Guia Quatro Rodas) destaca a descoberta e o compartilhamento de produtos nacionais: "de uns dez anos para cá estamos trocando o uso do termo exótico (...). Está havendo uma grande descoberta e pulverização de ingredientes do nosso celeiro, como frutas do norte e nordeste, que ajudam, inclusive, a construir a nossa identidade". Contudo, ele reitera que a gastronomia no Brasil ainda está muito associada à cozinha europeia e que a valorização ainda acontece mais nos grandes centros, porque as elites locais em outros lugares ainda estão mais interessadas em restaurantes moldados com base no conceito europeu.

Lopes (Gosto e O Estado de São Paulo) também expõe o papel de difusão de São Paulo, afirmando que "tudo partiu daqui". Entendendo que essa valorização está atrelada a uma melhora de qualidade, ele afirma que os restaurantes de maior 
exposição em todo o Brasil são inspirados em São Paulo, onde estão também os melhores chefs e o melhor serviço.

Castanho (Guia Quatro Rodas) compactua da importância da cidade e, justamente por isso, comemora o fato de terem melhorado os restaurantes de cozinha regional instalados em São Paulo, enfatizando, ainda, a crescente importância da gastronomia como parte da experiência turística e a oportunidade que isso representa para as cozinhas regionais brasileiras.

Justamente pela força das cozinhas regionais, Camargo (O Estado de São Paulo) acredita que talvez o grande movimento associado à valorização das gastronomia não aconteça em São Paulo, mas fora dos grandes centros. E acrescenta que, apesar disso, a cidade está hoje muito à frente dos outros lugares.

Para Castilho (Prazeres da Mesa), contudo, "fala-se muito [sobre a valorização da gastronomia brasileira], mas não sei se esta acontece tanto". Para ele, há um longo caminho a ser percorrido, inclusive para que se possa ter constância de produtos. Para que haja uma mudança no mercado "é preciso que o cliente encontre em vários lugares a mesma coisa, o mesmo produto, pra que a gente vá conquistando o paladar dele. Ele tem que experimentar. Não adianta só eu falar que é bom", afirma. Ainda, segundo ele, para valorizar a gastronomia brasileira não é preciso desconhecer o que é de fora; pelo contrário. Assim, defende que se deve usar aquilo que se tem no local, porém sempre em dia com o que se passa em outros lugares, buscando referências externas e ampliando os horizontes.

\subsubsection{São Paulo: local versus global}

Ao versar sobre a relação estabelecida entre local e global em São Paulo, os entrevistados enveredaram por diferentes caminhos. Os limites de o que é local e de o que é global assumiram interpretações distintas, evidenciando a subjetividade associada ao tema, não havendo consenso entre os entrevistados ao abordarem livremente a temática em seus depoimentos.

O que aparece de forma mais frequente e enfática, embora não proferido espontaneamente por todos os entrevistados, é que o fato de São Paulo ser multicultural e cosmopolita tende a ampliar ou diluir o conceito do que é local, nem sempre entendido com rigidez ou preso a conceitos geográficos. 
Para Castilho (Prazeres da Mesa) é mais difícil falar de "local" em São Paulo do que em outros lugares, visto que os produtos "vêm de fora". Contudo, ele não deixa de verificar que um diálogo entre o local e o global toma forma na cidade "na medida em que as coisas têm uma cara, uma característica própria”, mesmo que as referências sejam externas.

Para Melo (Guia Josimar e Folha de São Paulo), a "Cozinha Bossa Nova", expressão criada por ele para caracterizar 0 momento da gastronomia contemporânea em São Paulo, representa exatamente o diálogo entre o local e o global, ao conjugar aquilo que vem de fora com o brasileiro, dando origem a algo particular.

Já Lopes (Gosto e O Estado de São Paulo) afirma que, ao se falar de local em São Paulo, ele pensa no Brasil como a referência daquilo que é local. Ainda assim, considera muito pequeno o espaço do local perante o global na cidade, pontuando a pequena oferta de restaurantes brasileiros ante os internacionais.

Para Camargo (O Estado de São Paulo), o fato de São Paulo ser grande e cosmopolita talvez dilua um pouco os conceitos do local. Ele adiciona: “(...) São Paulo tem uma condição privilegiada que é poder trazer o local regional e produzir aqui, graças aos estudos agronômicos".

Embora não tenha se delineado consenso na livre expressão dos entrevistados sobre a questão local-global, quando questionados sobre a noção de local ser comumente alargada e passar a representar o nacional em São Paulo, todos eles concordaram.

Ainda nesse contexto, todos foram acordes em que "São Paulo pode ser considerada uma espécie de vitrine do Brasil e, mais do que isso, um ponto de conexão entre o local e o global, na medida em que pode representar o Brasil para aqueles que vêm de fora e o mundo, para os brasileiros". 


\subsection{Chefs e proprietátios de restaurantes}

\subsubsection{Mudanças no mercado de alimentação na cidade de São Paulo}

A multiplicidade de experiências vivenciadas pelos profissionais entrevistados, alguns dos quais ligados à gastronomia paulistana há mais de meio século (seja diretamente ou por meio da família), proveu relatos diversos sobre as mudanças que vêm transcorrendo no mercado de alimentação e mais especificamente de restaurantes na cidade de São Paulo, tanto no que se refere ao acesso a ingredientes e produtos, aos hábitos dos consumidores, aos restaurantes, quanto à atuação da mídia especializada.

\subsubsection{Ingredientes e Produtos}

Inúmeras questões foram abordadas pelos profissionais entrevistados no que diz respeito a ingredientes e produtos. Em linhas gerais, foi destacado um aumento na quantidade de produtos disponíveis e uma melhoria na qualidade destes, tendo sido mencionados, com base nessa temática, diversos aspectos não só atribuídos à adoção de produtos importados, mas também sobre os reflexos na produção nacional.

Entre eles pode-se citar a abertura do mercado na década de 1990, o incentivo dado pelos estrangeiros para que outros itens passassem a ser produzidos no Brasil e a introdução de novos produtos, por intermédio deles, muitos dos quais passaram a ser largamente utilizados na gastronomia paulistana. É possível entrever, ainda, a existência de diferentes realidades de compra vivenciadas pelos entrevistados, em virtude das especificidades do seu negócio e das suas convicções pessoais.

Nesse sentido, Henry (La Casserole) pontua, entre outras informações, que na década de 1950 não havia na cidade cordeiros para corte, somente para extração de lã, tendo sido seu pai um dos precursores da introdução dessa carne nos cardápios paulistanos: "aos poucos, meu pai conseguiu dar um salto de qualidade 
para produzir um bom cordeiro de corte, truta, queijos que, aos poucos, se pareciam mais com os franceses, ervas e outras coisas". Complementando a questão, ela destaca a importância de uma outra geração de franceses, vindos ao Brasil algumas décadas depois, entre os quais estão Laurent Saudeut e Emanuel Bassoleil, que entre outras contribuições, incentivaram o cultivo de ervas frescas para suprir o mercado paulistano.

Enquanto Henry (La Casserole) enaltece as contribuições francesas, Mellão Jr. (I Vitelloni) realça o trabalho de italianos como Massimo Ferrari, que apresentou aos paulistanos, dentre outras iguarias, o tomate seco, produto que o próprio Mellão Jr. usou em uma das suas mais célebres preparações, a pizza de rúcula com tomate seco e que se tornou uma constante nos cardápios paulistanos nos anos seguintes, fato também pontuado por Atala (D.O.M. e Dalva e Dito).

A maioria dos entrevistados, contudo, sublinha como principal fator de transformação a abertura das importações ocorrida no Governo Collor.

Segundo Bettencourt (A Bela Sintra), o Brasil antes e depois da abertura de importações "são dois mundos completamente distintos". Kuczynski (Arábia) posiciona-se de maneira semelhante, afirmando que essa abertura correspondeu a uma ampliação das possibilidades no cardápio: "hoje eu tenho uma meia dúzia de importadores que trazem produtos do Oriente Médio. (...) No começo, a gente não encontrava muitos ingredientes, e por não encontrar, não tínhamos os pratos que temos hoje. Vários pratos foram introduzidos a partir do momento em que se teve acesso a esses ingredientes".

Paralelamente à facilidade de entrada de produtos importados no país, desencadeada na década de 1990, Sakamoto (Jun Sakamoto) evidencia o trabalho de parceria realizado entre os restaurantes e as importadoras no sentido de ampliar a qualidade e diversidade encontradas em São Paulo: "eu cheguei nas importadoras e falei: eu preciso disso daqui, dá um jeito de trazer pra mim. Eles traziam uma amostra, e eu os convencia que valia a pena".

Assim, os entrevistados relataram que atualmente são encontrados em São Paulo produtos advindos de praticamente todo o mundo. E em adição a isso, muitos deles explicitaram ainda a ampliação da oferta e a melhoria da qualidade da matériaprima produzida no Brasil, inclusive de itens originários de outros países.

Nesse sentido, Jacquin (La Brasserie Erick Jacquin) afirma que a qualidade dos produtos nacionais melhorou e que está mais fácil encontrar aquilo 
que se deseja: "hoje, é possível fazer uma comida 100\% francesa utilizando, em parte, produtos brasileiros de qualidade, como o foie gras produzido aqui".

De maneira similar, Murakami (Kinoshita) destaca a introdução de gêneros japoneses nos últimos anos: "hoje já tem Wagyu, que é a raça japonesa do boi, $100 \%$ produzido aqui, você já tem o porquinho preto, que é famoso da região sul do Japão, da região de Kagoshima".

Iglesias Filho (Grupo Rubaiyat) reforça o que foi dito e chama atenção para a melhora na qualidade da carne produzida no Brasil: "hoje está se produzindo beef no Brasil; em termos de carne é uma das melhores carnes do mundo. Já se tem isso. O grande salto veio nesses últimos 20 anos". Ainda focalizando a melhoria da qualidade dos ingredientes no Brasil, Atala (D.O.M. e Dalva e Dito) declara: "hoje eu vejo essa melhoria nos ingredientes, o que nos permite fazer pratos muito simples".

Trajano (Brasil a Gosto) aponta maior interesse por produtos brasileiros e salienta o fato de que o aumento do consumo de gêneros regionais brasileiros por parte dos restaurantes paulistanos amplia o acesso a eles. Neste sentido, Carossela (Arturito) pondera: "desde que cheguei [ao Brasil] vi surgir alguma coisa. Cresceu um olhar muito interessante para o produto brasileiro".

Apesar das melhorias percebidas, alguns chefs e proprietários de restaurantes ainda se queixam da dificuldade de encontrar produtos frescos diariamente e de comprar de pequenos produtores: "para a oferta gastronômica de São Paulo, que é gigantesca, a oferta de produtos é triste pra mim. (...) Uma coisa que eu acho muito ruim é que os produtores de ingredientes interessantes (...) não chegam até mim", lamenta Carossela (Arturito).

Rizzo (Maní) é mais uma que se manifesta nesse sentido, ponderando que, embora as facilidades de comunicação tenham trazido grandes benefícios, ainda existe muito a avançar, em especial no que concerne à compra de produtos regionais e de ingredientes que venham direto dos produtores. De Barros (Due Cuochi Cucina) adiciona: "acho que falta um pouco dessa ligação com o produtor. (...) A pessoa que faz a farinha, a pessoa que planta, que colhe, e que "te" vende. Eu acho que é importante esse relacionamento".

Foram citadas ainda questões associadas às mudanças no fornecimento e na logística dos produtos. Embora alguns entrevistados não percebam modificações expressivas nesses aspectos, parte deles exprime considerações a respeito. Como aspectos positivos foram mencionados uma melhora na logística interna e no 
aumento dos fornecedores especializados, bem como as parcerias com fornecedores e as compras via telefone, com a afirmação de que as distâncias foram minimizadas com os recursos de comunicação e transporte. Como aspectos negativos apareceram a estagnação do CEAGESP (Companhia de Entrepostos e Armazéns Gerais de São Paulo) e a morosidade das importações.

Jacquin (La Brasserie Erick Jacquin), ao mesmo tempo em que realça o aumento dos fornecedores especializados, lamenta a estagnação do CEAGESP. Iglesias Filho (Grupo Rubaiyat) distingue a melhoria na indústria de food service e afirma que trocou as idas ao CEAGESP por empresas especializadas que entregam os produtos diariamente no restaurante. Mas critica, em contrapartida, a morosidade do processo de importação no país: "a importação está pior. Eu importo desde 1986. (...) Hoje está mais difícil liberar. Demora mais. Você falar de perecíveis é um caos. (...) Mas no que é produto interno, a logística interna está muito melhor. A indústria está muito melhor. O processamento está muito melhor".

Para Atala (D.O.M. e Dalva e Dito), um chef de cozinha não tem mais condições de ir pessoalmente fazer as compras em uma cidade como São Paulo, sendo preciso usufruir das facilidades da metrópole. Nesse contexto, ele manifestase em favor das parcerias com fornecedores e das compras por telefone, valorizando o estabelecimento de relações de confiança e apontando para a importância de ter um bom controle de recebimento no restaurante. Embora se queixe dos altos custos de transporte, ele afirma que "tanto faz se você pede na Cantareira, no CEAGESP ou no Amapá. Essa distância foi rompida pelo telefone e pelo transporte aéreo. Então, o que eu posso falar hoje é que o telefone e o controle de recebimento constituem a grande chave das compras".

Sakamoto (Jun Sakamoto) também se diz adepto das compras feitas por telefone, mas aponta uma outra mudança ocorrida dentro da sua estrutura: o fracionamento das compras e a utilização de cadeias varejistas em substituição de alguns fornecedores atacadistas. "Antes comprava alguns produtos em maior quantidade e com menor frequência, hoje faço justamente o contrário". A mudança é resultado de uma busca por preços mais baixos, que podem ser conseguidos em promoções realizadas pelos supermercados. 


\subsubsection{O Consumidor}

A importância que os hábitos e exigências dos consumidores representam para o mercado de restaurantes é explicitada por alguns entrevistados, ao descreverem que é o cliente quem dá o formato final ao restaurante.

Quando se trata das transformações que vêm sucedendo nessa área, há consenso em afirmar o crescimento da exigência dos consumidores. Além disso, a maior parte dos entrevistados é acorde quando ressalta que os principais impulsionadores dessas mudanças são a facilidade em viajar e o maior acesso a informações.

Nesse sentido, Miyamura (Eñe) conta que "a ideia inicial do Eñe era ser um bar de tapas (...), mas depois que a gente abriu, viu que o perfil dos clientes não era esse. (...) A partir daí, a gente mudou o foco. Claro que as tapas continuam, mas a gente teve que pensar em algo mais gastronômico".

Para Pister (Tenda do Nilo), "os brasileiros estão saindo muito para fora (sic), estão conhecendo restaurantes árabes lá fora e estão voltando com uma outra visão para o Brasil". Na mesma linha, mas abordando o mercado de forma mais abrangente, De Barros (Due Cuochi Cucina) declara: "As pessoas ficaram mais exigentes... hoje em dia todo mundo conhece os ingredientes, acho que a cozinha passa a ser um modo de vida, as pessoas começam a querer aprender a cozinhar, sabem o que estão comendo (...) podem viajar mais, estudam... houve uma grande mudança".

Paralelamente, Iglesias Filho (Grupo Rubaiyat) afirma que, além dos clientes hoje viajarem mais e terem mais referências, a exigência crescente é também resultado de uma maior liberdade de expressão: "o consumidor está mais exigente e mais democrático. Nos anos de 1960-70, [durante a] repressão, as pessoas também eram mais tímidas, mais comedidas. Hoje há uma maior liberdade de expressão que também gera maior questionamento".

Jacquin (La Brasserie Erick Jacquin) complementa afirmando que "as pessoas procuram mais comer bem, ter qualidade de serviço. Porque antigamente a exigência era por reconhecimento, o cliente queria ser chamado de doutor".

Além de destacar a crescente exigência dos consumidores, diversos entrevistados evidenciam mudanças nos hábitos de consumo, as quais foram exploradas por eles em algumas vertentes. 
Rios (Don Curro) afirma que "há uma grande mudança de hábitos". Segundo ele, com o aumento do trânsito e os problemas de segurança enfrentados na cidade, as pessoas saem menos; por outro lado, cresce vertiginosamente o movimento do serviço de delivery.

Martins Filho (Antiquarius) enfoca uma ótica distinta. Ele acredita que as pessoas hoje saem mais para comer, e defende que isso seja reflexo de algumas mudanças na sociedade: "a estrutura familiar está se alterando, e você não tem mais aquela estrutura que tinha no tempo do avô, que tinha cozinheira (...), ninguém mora em apartamentos e casas monstruosas. (...) Então você tem um lado social, de integração social, e você tem um outro lado... você precisa comer. No restaurante você vai comer, vai beber, vai encontrar com os amigos, vai conversar".

Para Trajano (Brasil a Gosto), o notável é que a elite brasileira passou a sair de casa para comer comidas brasileiras: "antes a elite comia, sim, um leitão pururuca, mas em casa, não saía de casa pra isso, ela está se habituando agora".

Outro tema destacado pela quase totalidade dos entrevistados é o fato de os clientes estarem mais preocupados com a saúde, o que vai refletir nas suas escolhas por um ou outro tipo de comida, até no restaurante. Segundo Treinta (Rufino's), “As pessoas querem saber o que estão comendo. Aprenderam a comer. Comem menos carboidrato, evitam carnes vermelhas em excesso, comem mais peixes e frutos do mar".

De acordo com Kuczynski (Arábia), "nos últimos cinco anos, os hábitos estão mudando radicalmente. As pessoas hoje estão voltando à ideia de que você é aquilo que você come. Então, vem uma preocupação com o que você está consumindo, a qualidade, a origem do produto...".

Fasano (Grupo Fasano), defendendo essa mudança de hábitos, relata que "hoje as pessoas, mais preocupadas com a alimentação, já não comem tanta gordura". É também nesse contexto que Murakami (Kinoshita) destaca o aumento no consumo de comida japonesa e Martins Filho (Antiquarius), afirma: "hoje [0 cliente] tem uma conscientização, busca uma alimentação mais saudável, menos calórica".

Um outro aspecto abordado, ao se tratar de mudança de hábitos, diz respeito à aceitação de produtos pelos consumidores. De acordo com o depoimento de alguns profissionais, o restaurante provoca mudanças no paladar dos clientes. 
Nesse sentido, Lazzarini Neto (Varanda) afirma: "o Varanda sempre foi um 'educador'. Quando nós abrimos o Varanda, $70 \%$ dos pratos que vendíamos eram do grupo picanha. Essa participação caiu no ano passado e estamos derrubando para $12 \%$ neste ano. Queremos tirar o mito da picanha." France (La Casserole) recorda-se de um exemplo também bastante ilustrativo: "lembro do meu pai contando que os clientes pediram para ele tirar o gigot d'agneau do cardápio. Imagina que os brasileiros iam comer pernil de cordeiro mal passado... Hoje é um ícone do cardápio".

\section{$\underline{5.2 .1 .30}$ restaurante}

As diversas transformações associadas à entrada de novos ingredientes e hábitos do consumidor e aquelas que sucedem na cidade repercutem diretamente no restaurante, podendo-se dizer que este, de certa maneira, sintetiza as várias mudanças que vêm acontecendo no mercado.

Somada a este entendimento, parte dos entrevistados percebe 0 restaurante também como um agente ativo de mudanças, uma vez que atua na oferta e divulgação de ingredientes, na criação de receitas e tendências, sendo, desta forma, não apenas influenciado, mas também influenciando o consumidor.

Vista hoje por muitos dos profissionais entrevistados como mais consistente, a oferta de restaurantes existente em São Paulo reflete, para eles, um amadurecimento do mercado.

Os reflexos das tantas mudanças podem ser observados, inclusive, do ponto de vista locacional, quando se trata de onde os restaurantes estão instalados e ao se verificar o surgimento de novas centralidades e a transformação de algumas áreas.

Parte dos entrevistados ilustra o movimento de restaurantes e outros estabelecimentos associados à gastronomia na cidade citando sua própria trajetória e a história de alguns estabelecimentos.

Para Fasano (Grupo Fasano), a trajetória dos estabelecimentos da família, iniciada com a Brasserie Paulista, no centro da cidade, no início do Século XX, reflete as mudanças pelas quais ela vem passando. Do centro, foram também para a região da Av. Paulista, e mais tarde se deslocaram para o eixo Itaim-Jardins, 
estabelecendo-se na Rua Amauri e depois na Rua Haddock Lobo, contando hoje com diferentes endereços nesses bairros. Ele afirma que até mesmo a venda da empresa e interrupção das atividades por dez anos foi motivada pela grande valorização imobiliária do conjunto nacional: "foi mais fácil vender a empresa do que vender o prédio".

Iglesias Filho (Grupo Rubaiyat) também aponta como a localização do restaurante vai acompanhando essas mudanças: "[o Rubaiyat] foi primeiro ali na Vieira de Carvalho, entre o Largo do Arouche e a Praça da República, que era considerada a Oscar Freire de hoje. Havia aquele quadrilátero ali, como o quadrilátero do Figueira hoje, por exemplo. Era o máximo na cidade, eu acho. (...) O nosso público se deslocou, saiu de lá. Os escritórios saíram de lá. (...) A gente acompanhou a cidade".

Henry (La Casserole), cujo restaurante está estabelecido no centro desde 1954, também fala das mudanças ocorridas na cidade, mas sob a ótica de quem permaneceu no mesmo endereço: "aos poucos, o centro de São Paulo foi se deslocando e deixou de ser o grande espaço de convivência. Tivemos dificuldades grandes na década de 1990. Naquele momento, as pessoas não queriam mesmo mais saber do centro. Mas, aos poucos, com a discussão sobre requalificação do centro, as pessoas começaram a recuperar o centro como referência e a querer retomar o convívio com os pontos históricos da cidade".

Um segundo ponto referenciado por grande parte dos entrevistados versa sobre o cardápio dos restaurantes. Entende-se que havia maior semelhança entre os pratos ofertados pelos restaurantes, o que crescentemente estaria sendo alterado por uma busca pela especialização.

Expressando tal ideia, Lazzarini Neto (Varanda) afirma: "quem não for especializado vai ficar em xeque". Nesse sentido, Iglesias Filho (Grupo Rubaiyat) salienta algumas mudanças pelas quais o restaurante foi passando no decorrer de seu meio século de história: "em termos de cardápio, o que aconteceu é que eu acho que cada um está mais especializado. Em carne, estamos muito mais focados nos cortes de carne. Antes, tinha um monte de camarão, um monte de coisas feitas na cozinha. (...) Nós saímos de uma cozinha internacional... havia churrasco com uma cozinha internacional... e nós fomos pra cozinha de fogo, de brasa, de forno à lenha, grelha... nós estamos muito nos grelhados, muito focados em carne e com muito menos pratos". 
Paralelamente, parte dos entrevistados atesta a semelhança entre os restaurantes de uma mesma especialidade. Ilustrando essa visão, Jacquin (La Brasserie Erick Jacquin) afirma que "os restaurantes franceses de São Paulo estão muito parecidos" e Mellão Jr. (I Vitelloni) diz que no mercado das pizzarias há "muita cópia".

Há consenso dos entrevistados em afirmar uma elevação na qualidade apresentada pelos restaurantes, fruto da qualidade dos produtos, da exigência dos consumidores, da maior concorrência e da profissionalização do meio, sendo esta um destaque bastante recente.

Analisando a concorrência, De Barros (Due Cuochi Cucina) faz um balanço positivo: "eu sempre enxergo a concorrência como uma coisa saudável (...). A concorrência aumentou, há restaurantes de bastante qualidade hoje em dia e isso é importante. Cada vez mais a gente quer aprender para poder estar um pouco à frente. Então, um puxa o outro". Além disso, ele aponta uma outra mudança no mercado. Segundo ele, há 20 anos, ninguém queria ser cozinheiro nem se formar cozinheiro, mas hoje passou a ser uma profissão desejada por muitos, uma vez que envolve certo glamour.

Fasano (Grupo Fasano) também percebe considerável mudança nesse âmbito, destacando que alguns anos atrás "não havia cozinheiros com curso superior como se tem hoje" e destaca ainda que cresce a oportunidade de estudar fora, em outros países, e surgem cursos com nível cada vez melhor na cidade.

llustrando a questão, Mellão Jr. (I Vitelloni) afirma: "há 25 anos, para quem estava numa cozinha, não saber ler era comum. (...) Foi muito rápido o que aconteceu".

O serviço e o ambiente do restaurante são apontados por todos os entrevistados como fatores de relevância e que também passaram - e continuam passando - por transformações na cidade de São Paulo. Aparecem, no entanto, visões distintas sobre o que é e o que não é valorizado atualmente neste contexto, apontando dicotomias, por exemplo, entre o luxo e o despojado, entre o formal e o informal. Ainda nesta temática, a mídia foi citada por alguns como influenciadora na criação de padrões.

Para Kuczinsky (Arábia), existe uma sofisticação do restaurante, que ele credita à atuação da mídia: "acho que a mídia foi nos levando para uma sofisticação, valorizando a figura do sommelier, cartas. Quer dizer, as casas que têm carta de 
vinho, as casas que não têm, as casas que têm uma carta de vinho mais elaborada, número maior de rótulos. Então, eu vejo que os restaurantes na verdade, foram se adaptando à valorização da mídia”.

Por outro lado, enquanto Jacquin (La Brasserie Erick Jacquin) aposta em talheres de prata para o ano de 2011, a narrativa de Atala (D.O.M. e Dalva e Dito) leva a refletir sobre uma mudança acerca do que se entende por luxo dentro de um restaurante: "de 1994 para cá o que a gente viu foi a gastronomia ganhando novos contornos, a alta cozinha deixando de ser tão formal. Ela hoje goza de uma informalidade que não tinha. Naquela época o serviço era mais formal, a louça era mais formal, você era obrigado a ter talher de peixe, era condição de um restaurante fino ter talher de prata. Hoje já não mais. Quer dizer, hoje pode ser um élan, mas não é obrigação".

\section{$\underline{\text { 5.2.1.4 A mídia especializada }}$}

A maioria dos entrevistados reconhece em seus relatos o crescimento da mídia especializada em gastronomia, traduzida, segundo eles, pelo aumento de publicações, canais destinados ao tema e pelo aprimoramento do trabalho jornalístico, em especial na última década. Para este grupo, a mídia vem mudando e crescendo de acordo com o mercado e, paralelamente, transformando-o.

Treinta (Rufino's), destaca que "quarenta anos atrás não existia mídia especializada (...) escrevia-se alguma coisa no jornal, mas sem se conhecer muito do assunto". Ilustrando a mudança, De Barros (Due Cuochi Cucina) afirma: "hoje em dia há jornalistas que conhecem gastronomia, que sabem, que comem, que viajam e cada vez estão mais críticos. Eu acho que vêm mudando, acho que eles veem, talvez, que têm que ter uma formação mais específica... O jornalista... não é porque fez jornalismo que vai escrever sobre comida(...). Acho que a pessoa precisa se aprofundar um pouco mais, acho que isso ainda precisa crescer um pouquinho, mas está evoluindo também".

Iglesias Filho (Grupo Rubaiyat) enfoca o crescimento da mídia associado-o ao amadurecimento do mercado: "a mídia, os jornalistas gastronômicos cresceram junto com a oferta (...). E é fruto do amadurecimento do setor, do amadurecimento da cultura, porque gastronomia é cultura". 
Ainda que boa parte dos profissionais entrevistados evidencie um amadurecimento da mídia especializada, há quem afirme não perceber mudanças estruturais. Ainda entre aqueles que notam uma mudança positiva, algumas críticas são proferidas. Algumas são feitas em relação à clareza e transparência dos critérios de seleção (de especialidades e de pratos) e avaliação adotados pelos diversos veículos; outras correspondem ao fato de o trabalho da mídia paulistana ter sido considerado por alguns interlocutores como menos aprofundado do que em outros lugares do mundo.

Nesse sentido, Henry (La Casserole), ao destacar a crescente profissionalização da mídia, pondera: "a mídia gastronômica se profissionalizou muito nas últimas décadas. Ficou mais exigente e acho bom porque nos 'ajuda' a perseguir níveis de qualidade cada vez mais apurados. Mas acho que a crítica gastronômica poderia fazer um caminho com o objetivo de deixar mais claros os critérios de avaliação." Sakamoto (Jun Sakamoto) concorda, afirmando: "nem sempre os critérios são bem estabelecidos".

Aliada às criticas feitas, alguns entrevistados ponderam a dificuldade do trabalho do jornalista na cidade e nos país, dada a significativa diversidade gastronômica - que demanda um leque muito variado de conhecimento por parte desses profissionais -, a própria extensão territorial do Brasil - que dificulta não só o conhecimento da oferta existente no país como também o acesso a diferentes lugares - e a falta de recursos enfrentada pelos veículos para subsidiar a construção de um referencial gastronômico criado com base em experiências em diversos lugares do mundo.

Nesse sentido, Lazzarini Neto (Varanda) coloca: "A mídia? Eu acho que ela abriu mais, aparecem novas revistas. Tudo bem que ainda não tem alguma coisa muito sistematizada, porque é muito difícil fazer crítica em São Paulo; os estilos são diferentes, entendeu? Quer dizer, você vai à França, na Itália, você tem cozinhas regionais, mas você tem um padrão".

Atala (D.O.M. e Dalva e Dito) enxerga também esta vertente, expressando, entre outras opiniões, a melhora e a dificuldade do trabalho da mídia no Brasil: "a mídia vem melhorando no Brasil, mas ela ainda é muito distante do que acontece no mundo. (...) Não é uma crítica ao jornalista, mas à mídia ampla. Então vamos dizer o seguinte: um jornalista europeu... é muito mais fácil para ele estar up to date. Ele 
toma um trem, que é barato, e vai comer num restaurante que está a alguns quilômetros do país dele ou da cidade dele e o veículo pode pagar."

Acrescenta-se a essas reflexões um tema que preocupa diversos entrevistados, qual seja a proliferação de outros canais de comunicação, como os blogs. Alguns questionam a qualidade e a responsabilidade da crítica expressada através de todos esses canais e há quem pondere que o excesso de informações pode "confundir as pessoas" como Carossela (Arturito) e Iglesias Filho (Grupo Rubaiyat).

Miyamura (Eñe) contextualiza: "o que está acontecendo agora, que não é bem imprensa, mas a explosão de blogs, de gente falando sobre comida". Nesse sentido, Sakamoto pontua também o crescimento e a expressão da internet: "a internet está ocupando o espaço; agora esses tablets de leitura estão cada vez mais acessíveis".

Outra questão observada por alguns entrevistados diz respeito à visibilidade que vem sendo dada pela mídia a determinadas cozinhas. Nesse sentido, Murakami (Kinoshita) destaca um flerte da mídia com a cozinha japonesa, propagando suas qualidades em termos de saúde: "eu acho que essa relação da cozinha japonesa com a mídia cresce porque, como eu sempre brinquei, desde a Liberdade, é a cozinha do futuro. No sentido de leveza, no sentido que o corpo agradece, que o corpo pede".

De forma análoga, Trajano (Brasil a Gosto) percebe crescente destaque conferido à cozinha brasileira, seja por meio dos restaurantes, de receitas e de ingredientes: "de uns anos pra cá a gente ganhou categoria... os restaurantes brasileiros passaram a concorrer aos prêmios de gastronomia, tanto na categoria gastronomia brasileira quanto com alguns pratos brasileiros".

\subsubsection{São Paulo Cosmopolita}

Ainda que o termo cosmopolita não tenha sido amplamente expressado pelos profissionais entrevistados ao caracterizar a cidade de São Paulo, essa noção permeia o discurso da maioria, seja quando caracterizam a oferta de restaurantes, ou mesmo ao se discutirem os impactos da globalização no mercado de alimentação em São Paulo. 
Para a totalidade dos entrevistados a oferta de restaurantes na cidade é entendida como multicultural, fruto da miscigenação populacional do país e da cidade. Destaca-se o fato de que os restaurantes étnicos ou associados à cozinha de um país, espelham as características de seu local de origem, sendo estas dosadas por adaptações locais, que ocorrem em menor ou maior escala.

\subsubsection{Oferta de Restaurantes em São Paulo na Atualidade}

A oferta de restaurantes em São Paulo é considerada por unanimidade como a melhor e a mais variada do país, sendo indicada como uma das melhores e mais diversificadas do mundo, a "número um" para alguns.

A grande marca da cidade, de acordo com os entrevistados, é a multiculturalidade, o entendimento de que convivem em harmonia cozinhas dos mais variados cantos do mundo.

Miyamura (Eñe) encanta-se com a possibilidade de encontrar na cidade "tudo, todos os dias, a toda hora. Você quer comer alguma coisa às quatro horas da manhã (sic) você consegue", diz ele.

Nesse sentido, Sakamoto (Jun Sakamoto) descreve a oferta de São Paulo como "a mais internacional de todas. A gastronomia paulista realmente tem uma quantidade gigante de restaurantes."

Henry (La Casserole), compartilhando dessa opinião, diz: "oferta como a paulistana não há em nenhum lugar do mundo. Durante muito tempo, tivemos italianos, franceses, portugueses, chineses. Agora, espanhóis, peruanos, fusion e muitas outras caras e tendências. Acho que há em São Paulo tudo de bom. Às vezes, eu fico pensando que se pode ficar quinze dias comendo a cada dia uma especialidade diferente... E de super boa qualidade".

Para Martins Filho (Antiquarius), "os restaurantes são a praia do paulista". Nesse contexto, o ecletismo da cidade que congrega "do botequim ao três estrelas", segundo Iglesias Filho (Grupo Rubaiyat), evidencia-se.

Consoante, Atala (D.O.M. e Dalva e Dito) classifica a oferta gastronômica de São Paulo como "das melhores do mundo", mas alerta para a quase ausência de restaurantes asiáticos na cidade. "Eu falo [dos] tailandeses, cambojanos, que esse é um viés que o Brasil e São Paulo não aprenderam a aceitar ainda. O Rio aceita 
melhor que São Paulo. O resto, as cozinhas mundiais estão representadas. (...) A grande força de São Paulo é exatamente essa, a diversidade de oferta”.

\subsubsection{Os restaurantes "aqui" e "lá"}

Com uma gama de restaurantes que remetem a diferentes países e culturas, diversas questões foram mencionadas no que se refere à fidelidade desses estabelecimentos e cozinhas a seus locais de origem e à sua adaptação a São Paulo. Particularidades associadas à nacionalidade da cozinha do restaurante e do entrevistado marcaram as expressões acerca do desenho do estabelecimento no Brasil em contraponto aos restaurantes no país de origem.

Dos restaurantes pesquisados, apenas no caso da Pizzaria Braz a aproximação com São Paulo faz parte do conceito do restaurante. Nos demais casos, o entendimento é de que quando foram estabelecidos tinham sempre a referência de seu país de origem, tendo as adaptações à cidade florescido de forma natural e cumulativa, associadas à disponibilidade de produtos e à aceitação do consumidor.

Importante salientar que, embora todos os entrevistados tenham diagnosticado adaptações - em aspectos e graus distintos -, não é expresso juízo negativo associado a elas; os entrevistados - sem exceção - conferem naturalidade ao fato e exemplificam as diferenças percebidas em seus restaurantes em São Paulo versus o local de origem.

Segundo Da Costa (Bráz), quando abriram a pizzaria Bráz "[eu] falava, estamos chegando ao mercado da pizza com 80 anos de atraso, porém oferecendo um conceito de produto novo (...) e a isso nós acoplamos um conceito de comunicação também novo, no sentido de que toda pizzaria em São Paulo de alguma forma se referia muito à Itália (...). Nós falamos: espera aí! A pizza tem uma história relacionada à cidade, São Paulo tem uma pizza própria, que chega pela mão dos italianos, mas que mistura o costume paulistano e adota um novo modelo (...). São Paulo tem um jeito de comer pizza diferente de qualquer outro lugar do mundo".

Os dois representantes da cozinha portuguesa que foram entrevistados, narram uma situação particular. Embora sejam considerados portugueses, e seus fundadores o são, não se definem exatamente como tal, mas como restaurantes 
internacionais. Para ambos, o que sucede é que ter bacalhau no cardápio é sinônimo, no Brasil, de restaurante português.

Martins Filho (Antiquarius) conta que o Antiquarius surgiu quando seu sogro, proprietário de um restaurante consolidado em Portugal, decidiu ir para o Rio de Janeiro. No momento de definir o cardápio, ele percebeu que diferentemente do bacalhau, itens como pato, codorna e leitoa como se faziam em Portugal não eram consumidos no Brasil. Assim, ao mesmo tempo em que pratos portugueses consagrados teriam um peso importante, ele optou por congregar também no cardápio pratos da cozinha internacional e alguns da culinária brasileira, como picadinho e carne seca. Desta forma, para ele, "o Antiquarius é um restaurante internacional com características portuguesas mediterrâneas (...). Mas o pessoal chega aqui, vê bacalhau: 'é português' e acabou".

Bettencourt (A Bela Sintra) posiciona-se de modo bastante similar. Afirma que, se estivesse em Portugal, o cardápio do $A$ Bela Sintra não seria o mesmo; incluiria mais itens de mar e caças, produtos não habitualmente consumidos no Brasil. Ademais, destaca que os restaurantes em Portugal estão muito voltados para os grelhados, diferente do que se vê aqui, e conclui: "o que fazemos aqui no Bela Sintra não é uma cozinha só portuguesa, mas é uma cozinha internacional. Nós temos pratos brasileiros, como tem alguma coisa francesa, italiana, espanhola...".

Em entendimento análogo, Fasano (Grupo Fasano) embora reforce a preponderância italiana do Fasano, entende mais adequado classificá-lo como internacional, expressando-se da seguinte maneira: "o Fasano, hoje, tem uma tendência italiana, com certeza. Mas você vai dizer se é típico italiano e eu vou dizer que não". De Barros (Due Cuochi Cucina), o outro entrevistado representante dos restaurantes italianos em São Paulo, entende seu restaurante como uma expressão da "cozinha clássica italiana" e, no exercício de contrapor o Due Cuochi Cucina a um restaurante baseado na Itália expressa "considero o restaurante muito pouco brasileiro. Um ou outro ingrediente até usa, mas dentro da cozinha italiana".

Importante salientar que, conquanto as adaptações sejam reconhecidas, a maioria dos profissionais entrevistados considera seu restaurante muito fiel à origem. Algumas peculiaridades são destacadas pelos representantes das diferentes origens e percebe-se, na fala dos entrevistados, características e paralelos entre São Paulo e o local de origem da cozinha representada pelo restaurante. 
Para os dois representantes da cozinha Francesa entrevistados quase não se nota diferença entre seus restaurantes aqui e os estabelecidos na França; a única exceção está associada ao serviço.

Segundo Jacquin (La Brasserie Erick Jacquin), "os clientes aqui estão economizando passagem de avião. As pessoas que entram aqui na Brasserie, tirando a língua portuguesa que os garçons falam, [percebem que] é um restaurante francês. Poderia estar em Paris". Consoante, Henry (La Casserole) diz que a alma de seu restaurante é francesa e afirma: "o La Casserole é francês no espírito, decoração e cardápio [típico de bistrô]. Acho que é brasileiro no serviço".

Assemelha-se a posição dos entrevistados representantes dos restaurantes espanhóis, que consideram a comida servida nos estabelecimentos como puramente espanhola, afirmando não haver adaptações nas receitas. Desta Forma Rios (Don Curro) caracteriza o Don Curro como "cozinha tradicional espanhola" e Miyamura (Eñe), afirma: "deste o início, uma das propostas era manter o restaurante estritamente espanhol", expressando motivo de orgulho por não terem feito concessões ao paladar paulistano, não terem abrasileirado clássicos como a paella, e mais do que isso, terem trazido para o Brasil "uma amostra da cozinha espanhola moderna - para que os espanhóis que moram aqui no Brasil consigam lembrar da comida ou do clima de lá".

A única ponderação feita por Miyamura (Eñe), chef do restaurante, é que o Eñe é um recorte do que se encontra na Espanha, tomando uma forma em alguma proporção caricatural, que foi desenhada propositadamente para que os elementos do restaurante - cardápio, carta de vinhos e ambiente - remetam à Espanha. Desta forma, o conceito do Eñe nasceu para estar fora da Espanha, para que os espanhóis que moram aqui no Brasil consigam lembrar da comida ou do clima de lá e , em função disto pondera: "Na Espanha, a comida até poderia ser a mesma, mas não exatamente o espaço e o conceito. Por exemplo, esses detalhes em vermelho [aponta para o desenho de uma tourada que estampa o grande vidro que divide o salão e a cozinha], ou o fato de só termos vinhos espanhóis (...) seria um pouco demais lá, mas aqui a gente quer difundir a cultura espanhola”.

Ser fiel a uma cozinha ou a uma cultura não significa, contudo, se assemelhar, necessariamente, ao que oferecem os restaurantes daquele local. É o que mostram os representantes da cozinha árabe, ou mais especificamente libanesa, como se definem os próprios entrevistados dessa especialidade. Nos dois 
casos, eles afirmam que o cardápio dos seus restaurantes reflete mais a comida caseira do Líbano do que o que é ofertado nos restaurantes de lá atualmente.

Pister (Tenda do Nilo) conta: "tem pratos que a gente faz aqui [no restaurante Tenda do Nilo] que você não encontra em restaurante no Líbano, quase impossível. Restaurante tem mais é homus, babaganuch... Charuto de uva você não encontra. A nossa comida é muito caseira, mais trabalhosa".

Kuczynski (Arábia), em consonância com a colega, declara: "em termos de comida libanesa a gente tem uma coisa que está muito enraizada na imigração do começo do século passado. Tanto é que hoje o cardápio do Arábia é muito mais extenso do que um cardápio de um bom restaurante no Líbano. Tem parentes da Leila $^{23}$ que vêm pro Brasil, olham nosso cardápio e dizem: 'Nossa, isso aqui não tem, isso a gente só come em casa, em ocasiões especiais'. (...) Essa comida é quase uma reserva cultural que se tem aqui, que lá eles não guardam tanto".

Os dois chefs japoneses entrevistados trazem à tona uma outra questão que é a culinária japonesa no Brasil ter recebido forte influência americana. Nesse sentido, Murakami (Kinoshita) destaca o uso de frutas nos sushis, os "Califórnia rolls", e pontua ainda o fato de o próprio Japão estar assimilando em parte essas influências. No entanto, quando diz respeito à adaptação dos restaurantes a São Paulo ou ao Brasil, os dois apresentam opiniões divergentes.

Murakami (Kinoshita) diz que apesar de o restaurante ter uma alma japonesa e essa ser a base da sua cozinha, existe uma preocupação em agradar o paladar paulistano. Além disso, relata que "um restaurante japonês em São Paulo, mesmo se utilizando de produtos importados, é um restaurante com produtos daqui", destacando a força do regionalismo no Japão e a importância que os produtos de um lugar exercem no contexto japonês. Aliado a essa explicação, pontua ainda a especialização dos restaurantes de lá, havendo aqueles, por exemplo, que se dedicam exclusivamente a lamen ou a sushi, o que não se encontra aqui.

Enquanto isso, Sakamoto (Jun Sakamoto) aponta adaptação em contraste ao Japão, mas não expressa influência diretamente paulistana ou brasileira e afirma que o restaurante pode ser considerado " $75 \%$ japonês e $25 \%$ ocidental, mas não brasileiro", e que poderia estar em qualquer outro lugar.

\footnotetext{
${ }^{23}$ Nota da autora: em referência à Leila Youssef Kuczynski, esposa de Sérgio Kuczynski, também proprietária do Restaurante Arábia, de origem libanesa.
} 


\subsubsection{Globalização}

Ao discutirem os efeitos da globalização e uma possível homogeneização decorrente desse processo não houve consenso entre os entrevistados.

Há aqueles que, como Fasano (Grupo Fasano) e Sakamoto (Jun Sakamoto), defendem que a globalização implica uma "homogeneização inevitável", assim como os que não concordam com essa ideia.

Para Iglesias Filho (Grupo Rubaiyat), o que transcorre é uma massificação do consumo, causada pela ascensão de alguns mercados e não uma padronização do gosto.

O que se nota é que a maioria das opiniões colhidas reflete uma dialética intrínseca ao próprio processo de globalização, que em mão dupla dissemina padrões que se tornam mundiais e abre portas para a valorização do que é particular.

Ainda, se para alguns a homogeneização se agrava progressivamente, para outros está se revertendo. É no que acredita Trajano (Brasil a Gosto), ao enfatizar o processo reverso, associado à diferenciação: "os supermercados são os grandes uniformizadores do gosto. Mas em razão de movimentos que estão acontecendo pelo mundo, como os orgânicos, com maior informação disponível e com as doenças vindo à tona, as pessoas estão questionando mais (...). Vejo uma mudança aí".

Nesse sentido, Atala (D.O.M. e Dalva e Dito) defende que a globalização "valoriza o trabalho diferencial. Esse é o conceito do luxo, não?!" E destaca ainda que o grande diferencial do D.O.M. é "cantar a própria tribo".

Para Carossela (Arturito), a globalização também traz muitos benefícios, pois amplia o leque de conhecimento. O problema, segundo ela, é que "temos informação demais e não sabemos escolher entre elas".

Em uma visão ampla, que reúne parte do que foi exposto por outros entrevistados, Henry (La Casserole) pontua: "acho que a globalização é contraditória. Tem aspectos, sim, de homogeneização e estandardização do gosto. Mas também traz a possibilidade de encontrar todos os bons ingredientes do mundo todo em qualquer lugar. Há hoje chefs franceses e ingredientes franceses em todos os lugares do mundo: praticando cozinhas criativas usando ingredientes locais também. Ou seja, o local e o global acabam tendo um diálogo rico como nunca 
tinham tido antes. Acho que isto vem contribuir com o processo criativo, na medida em que as possibilidades tornam-se tão variadas".

\subsubsection{São Paulo, Brasil}

A amplitude e a miscigenação são marcas apontadas pelos entrevistados como características da comida brasileira. É pontuada por parte dos entrevistados a influência europeia na oferta de restaurantes paralelamente à evocação, proferida por todos, de que se vivencia um momento de valorização da gastronomia brasileira.

A cidade de São Paulo, já caracterizada como o mais expressivo mercado do país, é reforçada agora também como principal sede de movimentos associados a tal valorização.

A temática que envolve o local e o global na cidade assume contornos amplos, mas expressado em um contexto alargado, no qual, para a maioria dos entrevistados, o nacional é entendido como local.

\subsubsection{A comida brasileira e a mesa paulistana}

Definir o que é comida brasileira e relacioná-la aos hábitos dos paulistanos foi tratado como tarefa complexa para a maioria dos entrevistados. Ao discorrerem sobre o que é comida brasileira, as abordagens consentiram no sentido de salientar a diversidade, a mistura, o fato de cada região apresentar comidas diferentes e existirem vários países dentro de um só.

A complexidade, associada a múltiplas influências, é uma característica citada pela quase totalidade dos entrevistados. Na missão de definir a comida brasileira surgiram expressões como "caldeirão de culturas", utilizada por Kuczinsky (Arábia), "colcha de retalhos" por Atala (D.O.M. e Dalva e Dito), "mistura de tudo" por Jacquin (La Brasserie Erick Jacquin) e "conjunto de influências" por Lazzarini Neto (Varanda). Parte dos entrevistados preferiu, ainda, caracterizar a comida brasileira através de pratos, como a feijoada, ou modos de preparo. 
Já ao estabelecer a relação entre aquilo que é consumido pelo paulistano e a noção de cozinha brasileira, os entrevistados adotaram posturas distintas.

Segundo Kuczinsky (Arábia), "a gente tem um caldeirão de culturas, as pessoas foram trazendo as coisas, foram adaptando". Nesta linha, Martins Filho (Antiquarius) coloca: "a comida brasileira é uma mistura. Nunca teve pretensões de ser uma coisa técnica, entende?".

Para Jacquin (La Brasserie Erick Jacquin), a comida brasileira "é uma mistura de tudo: crioulo, italiano, português...", uma mistura de culturas, da qual, contudo, os franceses não fazem parte, porque, sob seu ponto de vista, "o francês mudou a história do Brasil, mas não entrou na história do Brasil. Tem poucos franceses aqui".

Agregam-se ainda algumas visões mais específicas, que não deixam de apontar para a pluralidade. De Barros (Due Cuochi Cucina) reforça a origem dos produtos e sua forma de preparo ao definir a comida brasileira como "uma comida da terra, uma comida de raiz, com gosto de terra, de sabor de terra, de lembrança de mato, de fazenda, de lenha... são essas as coisas que me vêm à cabeça quando penso em comida brasileira”. Na perspectiva de Mellão Jr. (I Vitelloni), “a cozinha brasileira é de uma complexidade e de uma multiplicidade inacreditável, porque são 500 anos de pobreza. E a pobreza é o maior incentivador de receitas, pois se tem que lidar com o que está na frente".

Somada à diversidade, nota-se na fala de alguns entrevistados um dinamismo associado à definição de comida brasileira, como exemplificado por meio das falas de Kuczinsky (Arábia), Trajano ( Brasil a Gosto) e Rizzo (Maní).

Kuczinsky (Arábia) pontua duas fases: "acho que [a comida brasileira] é uma comida que tem influência de inúmeras culturas que vieram pro Brasil, utilizando os ingredientes e adaptando os ingredientes que a gente tinha aqui. Isso numa primeira fase. Na segunda fase, acho que a gente vê uma série de ingredientes que ainda estavam restritos a populações muito específicas, seu consumo era muito restrito, e agora estão aparecendo, estão fazendo sucesso. Difícil definir comida brasileira”.

Trajano (Brasil a Gosto) enxerga também um novo estágio: "agora o que a gente está tendo é uma tentativa de fazer uma cozinha brasileira mais moderna. Respeitando tradições, utilizando os mesmos ingredientes, mas tentando suavizar algumas coisas (...) para que ela entre um pouco mais no paladar e quebre esse preconceito de que a comida brasileira é gordurosa e pesada". 
Por sua vez, Rizzo (Maní) identifica um momento de descoberta vivido atualmente: "o brasileiro tem um modo de comer muito misturado. (...) O Brasil sempre foi um pouco internacional. A gente está tentando descobrir o que a gente é. A gente mais abraça do que rejeita aquilo que vem de fora".

Assim, a adaptação é também um fator reconhecido por grande parte dos entrevistados como uma marca da comida brasileira. Percebe-se, inclusive, na expressão de alguns, que comidas originalmente trazidas de outros países podem ser reconhecidas como brasileiras, ao assumirem contornos próprios.

Lazzarini Neto (Varanda) afirma: "a comida brasileira é um conjunto de influências africanas, indígenas, portuguesas, italianas e de tudo que tem aí. Você tem comida italiana, mas é claro que as comidas italianas brasileiras não são como as comidas italianas originais, entendeu? A nossa pizza foi reinventada aqui. Então, você pode considerar a pizza brasileira, ou o modo brasileiro de fazer a pizza".

Na mesma linha, Atala (D.O.M. e Dalva e Dito) aborda uma vertente cultural, também pontuada adiante por Carossela (Arturito), e defende: "quando a gente fala de brasileiro a gente não tem que ter fobias a outros ingredientes. Tem que estar no nosso DNA cultural. (...) Eu acho que o que está dentro da nossa cultura é brasileiro. (...) A nossa pizza é brasileira, o nosso macarrão é diferente do italiano".

Diante de tamanha diversidade, transparece a dificuldade dos entrevistados em distinguir, afinal, o que é e o que não é ou o que pode ou não pode ser considerado brasileiro no contexto paulistano.

Trajano (Brasil a Gosto) pontua primeiramente uma distinção entre a comida brasileira e aquela que utiliza ingredientes brasileiros. Comida brasileira, para ela, remete à cozinha mineira, nordestina, a pratos regionais de maneira geral. Para ela, o que o paulistano, ou pelo menos a elite paulistana, come não é comida brasileira.

Carossela (Arturito), por sua vez, primeiramente destaca o valor cultural que a comida tem para o brasileiro: "a feijoada às quartas e sábados, o arroz e feijão, a farofa, o peixe, o queijo de coalho na praia, o milho quente na praia, a água de coco, a batida de amendoim, a caipirinha, o açaí... são coisas muito locais e que estão muito dentro da cultura brasileira, em qualquer nível social. E isso, pra mim, é o que faz a cultura da cozinha nas pessoas". E ao falar de São Paulo, profere: "eu acho que tudo que é popular é brasileiro... A padaria, o boteco, o pão de queijo, o carrinho 
na rua (...). Não são regionais, talvez, mas são brasileiras, paulistanas ou são abrasileiradas".

\subsubsection{2 "Valorização da gastronomia brasileira"}

A maioria dos entrevistados tratou a discussão acerca da "valorização da gastronomia brasileira" como algo que diz respeito a ações e movimentos associados a itens tidos como nacionais, sobretudo ingredientes e técnicas, independentemente do tipo de comida preparada ou da origem dos ingredientes.

A grande parte dos entrevistados afirma a existência atual e recente de movimentos que buscam mostrar, resgatar e valorizar itens associados à gastronomia brasileira, embora existam distintas opiniões acerca da amplitude e estágio destes movimentos. Alguns os consideram pouco expressivos, muito recentes e acreditam que devam ainda se intensificar, enquanto outros já conseguem perceber uma realidade de expressão superior à que se observava em passado recente.

A maior visibilidade - em alguns casos do país no exterior, em outros, de ingredientes brasileiros ainda pouco conhecidos ou de itens não muito valorizados no mercado nacional - foi tema destacado pela maioria dos entrevistados.

Kuczinsky (Arábia) destaca que "os ingredientes, principalmente do norte e do nordeste e talvez um pouco do cerrado, que eram de total desconhecimento do mundo, pelo trabalho de algumas pessoas foi sendo mostrado. (...) O Brasil também passou a fazer parte dessa tendência mundial de consumo, de mostrar novidades. Acho que isso mudou muito".

Nessa linha, Iglesias Filho (Grupo Rubaiyat) acrescenta que há hoje um olhar mais aguçado para a gastronomia brasileira. Ele entende essa "valorização da gastronomia brasileira" como internacionalização e enfatiza, concomitantemente, a importância de São Paulo ter se posicionado como capital mundial da gastronomia e a participação de chefs brasileiros em eventos internacionais.

$\mathrm{Na}$ visão de Atala (D.O.M. e Dalva e Dito), uma mudança que deve ser comemorada é a seguinte: "antes o ingrediente brasileiro era um suporte para a magistralidade da cozinha francesa. Hoje não. Hoje a técnica europeia é um underline para um ingrediente". 
Assim como Atala (D.O.M. e Dalva e Dito), outros entrevistados reforçaram esse maior interesse dos profissionais em atuação no mercado em trabalhar itens nacionais - ingredientes, produtos e receitas.

Carossela (Arturito) relata ter sentido uma mudança no decorrer dos anos em que está no país: "quando eu cheguei [ao Brasil], tinha os restaurantes brasileiros, mas a maioria dos chefs só tinha interesse por cozinha europeia ou americana. E ao longo dos anos, os chefs mais jovens ficaram conhecidos por estarem a incluir receitas brasileiras com apresentações e técnicas diferentes. (...) Mesmo eu não fazendo cozinha brasileira, eu estou começando a usar azeite de coco, de castanha", diz ilustrando a absorção de ingredientes nacionais.

Mas diante desse interesse crescente por elementos brasileiros, Mellão Jr. (I Vitelloni) clama a necessidade de uma compilação do receituário nacional como forma de proteção à cozinha brasileira. Segundo ele: "hoje estamos tendo criações em cima do receituário que ainda não está compilado e, portanto, devidamente quantificado. Eu acho super legal trabalhar com cupuaçu, mas a pessoa não percebe o traço de origem do cupuaçu, entende?".

Para Sakamoto (Jun Sakamoto), a 'valorização da gastronomia brasileira' processa-se de modo quantitativo e qualitativo. Segundo ele, "cresce a economia, cresce a formação de um mercado para isso. O mercado que tem dinheiro quer descobrir, quer consumir o que o outro não pode consumir e se gabar por isso. Faz parte da natureza humana querer se diferenciar. Com isso, a gente vê a gastronomia crescendo. É um produto de luxo".

Mesmo partindo de diferentes entendimentos sobre o tema e abordando a questão sob óticas diversas, a opinião dos entrevistados no que diz respeito ao papel de São Paulo nesse processo de valorização da gastronomia brasileira mostrou-se consensual.

Todos os entrevistados destacam a importância da cidade, seja como o principal polo econômico e gastronômico do país, como local que dita tendências, como locomotiva da gastronomia brasileira hoje, por sua capacidade de projeção ou como a sede de renomados profissionais da área gastronômica.

Assim, embora haja divergências e tenham sido feitas algumas ressalvas sobre a posição e o envolvimento de São Paulo nesse processo, seu papel é entendido como fulcral, como ilustram Trajano (Brasil a Gosto) e Henry (La Casserole). 
Henry (La Casserole) destaca que o papel de São Paulo é contraditório, mas não deixa de reconhecer sua importância, na medida em que afirma que apesar de os produtores estarem distantes, é na cidade que surge o primeiro pontapé na direção dessa valorização.

Já para Trajano (Brasil a Gosto), não obstante São Paulo ter um envolvimento tardio, não significa que seja menos importante: "São Paulo foi o último a entrar no movimento em prol de uma gastronomia brasileira que começou com Paulo Martins Filho, César Santos. (...) O papel de São Paulo é vanguarda. Tudo que São Paulo fala dita moda. Então, de nada adiantava, por exemplo, Cesinha Santos falar de cozinha brasileira, se o mercado de São Paulo não tivesse comprado essa tendência. Porque ele que exporta as nossas tendências, é o grande polo gastronômico do Brasil. É a grande referência. Uma das referências mundiais hoje em gastronomia".

\subsubsection{São Paulo: local versus global}

A temática que envolve a relação local versus global foi discutida no decorrer das entrevistas em uma multiplicidade de aspectos. Fica claro que São Paulo é, para todos os entrevistados, uma zona de diálogo entre o local e o global; o que precisa ser explicitado é que para cada um deles tal postura pode representar coisas distintas, em decorrência daquilo que se está delimitando por local e por global.

Nesse contexto, é interessante ressaltar, por exemplo, que, ao entrevistar os responsáveis pelos dois restaurantes especializados em carne, Iglesias Filho (Grupo Rubaiyat) considera-se "local", pois o churrasco no seu entender é brasileiro, e seus restaurantes fora do país são vistos como brasileiros, enquanto Lazzarini Neto (Varanda) se diz absolutamente "global", ao comparar-se com as melhores steak-houses do mundo.

Deve-se atentar igualmente para o conceito de local que parece flexibilizar-se em São Paulo, tendo sua noção alargada e passando a nacional para a maioria dos entrevistados (à exceção de um), como se pode verificar por meio das falas de Iglesias Filho ( Grupo Rubaiyat) e Carossela (Arturito). 
Para Iglesias Filho (Grupo Rubaiyat), "em São Paulo o local é o nacional". Já Carossela (Arturito) afirma: "minha primeira noção de local é que seja brasileiro, a segunda noção é que seja próximo a São Paulo".

E nessa perspectiva, quando questionados, todos os entrevistados concordam que "São Paulo pode ser considerada uma espécie de vitrine do Brasil e, mais do que isso, um ponto de conexão entre o local e o global, na medida em que pode representar o Brasil para aqueles que vêm de fora e o mundo, para os brasileiros". 


\section{CONSIDERAÇÕES FINAIS}

Em São Paulo, parece haver uma necessidade de se repensar aquilo que é paulistano dentro do atual contexto dessa sociedade, de se buscar um novo entendimento do que é a sua cozinha em função do que está sobre a mesa das pessoas - que engloba, cada vez mais, o que é servido nos restaurantes, bares, cafés e padarias (entre outros estabelecimentos), quando considerado o hábito crescente de se alimentar fora de casa.

Deve-se estar atento ao fato de que não existe culinária atemporal, já que nas diversas regiões do mundo, os hábitos alimentares foram mudando no decorrer do tempo. Qualquer tradição alimentar que se tenha, em algum momento anterior, correspondeu a algo novo, mas, que uma vez aceito por aquele grupo de pessoas, passou a fazer parte de suas referências pessoais e coletivas, e a servir de base para novas transformações.

A própria noção de uma culinária brasileira que congrega influências portuguesas, africanas e indígenas, não raro proclamada como a genuína cozinha brasileira, é uma marcação temporal, referenciada numa ideia de igualdade racial que se pretendia transmitir no século XIX. Uma culinária que já absorvera espécies vindas de outros continentes, como o coco, a manga, a banana e o arroz, e que apresentava profundas diferenças nas diversas regiões do país, inclusive pelas influências exercidas por outros povos.

A cidade de São Paulo, conforme demonstrado, tem um processo de composição sociodemográfica particular e extremamente dinâmico, com reflexo direto sobre a mesa paulistana. A população da cidade cresceu 180 vezes em menos de um século, em decorrência de intensos fluxos imigratórios e migratórios que a ela se destinaram, reforçando, assim, o caráter fortemente mestiçado de sua população.

Consolidando-se como predominantemente urbana e distanciando-se rapidamente da realidade de subsistência que marca o período colonial, passou a se relacionar com outras áreas produtivas desde aquela época, tendo se tornado um importante elo de distribuição de produtos alimentares para outros núcleos urbanos, e mais do que isso, o principal posto de comando desse mercado. 
Cada um dos que desembarcaram na cidade, imigrantes e migrantes, trouxeram consigo seus hábitos alimentares que seriam replicados em maior ou menor grau, de acordo com as suas condições socioeconômicas. Enquanto novos produtos, técnicas culinárias e receitas foram sendo apresentados aos habitantes da cidade, a indisponibilidade de determinados ingredientes fez com que algumas receitas fossem adaptadas e outras, suprimidas do cardápio. A nova realidade tornou comidas do dia a dia em refeições de dia de festa, garantiu um novo status para algumas preparações e motivou o surgimento de outras receitas. De tal modo, ao mesmo tempo em que seus hábitos iam se disseminando, iam sendo igualmente ressignificados.

No entanto, migrantes e imigrantes não podem ser entendidos sob a mesma ótica, porque os imigrantes, sobretudo europeus, foram favorecidos pelas condições de mercado, inclusive em virtude de teorias como a da valorização da raça branca, o que facilitou sua ascensão social e a reprodução de muitos de seus hábitos; enquanto os migrantes, por nem sempre terem tido as mesmas condições de ascender socialmente, tiveram seus hábitos alimentares mantidos mais restritos a esses próprios grupos, à margem da alta sociedade paulistana.

Assim, considerando-se que muitos imigrantes tenham passado a compor a elite da cidade, aliado ao fato de a própria elite nacional preferir a identidade europeia como forma de se diferenciar dos demais habitantes do país, mantendo muitas vezes "escondidas" dentro de casa receitas e hábitos que remetessem à vida rural, propiciou que essas cozinhas ganhassem maior destaque dentro da gastronomia nacional, compondo a imagem de uma oferta cosmopolita que, por sua vez, se torna uma marca forte da cidade.

Deve-se notar, contudo, que vai se constituir em São Paulo uma oferta multicultural com características próprias, que vai se desenvolver, durante certo tempo, quase que isolada das suas matrizes, evoluindo independentemente daquilo que transcorria naqueles lugares.

A reaproximação se deu somente na década de 1990, com as facilidades de comunicação e transporte somadas à abertura das importações no país, o que permitiu que uma nova leva de produtos importados invadisse a cidade, e estivessem disponíveis nas gôndolas de supermercado - que se estabeleceram nas décadas anteriores, mudando completamente a realidade da distribuição no país. $E$, 
incorporar no cardápio esses produtos importados, tidos como de melhor qualidade, será marca distintiva nos restaurantes da capital paulista.

Concomitantemente a uma maior acessibilidade a esses produtos, a mudança no cenário econômico do país, com o alargamento da classe média e a valorização da moeda frente ao dólar, também vai possibilitar a um número maior de pessoas terem acesso a itens que até então estavam restritos a um pequeno grupo de pessoas, ampliando o mercado consumidor e tornando esses consumidores mais exigentes na medida em que adquirem novas referências de qualidade e variedade.

Desse modo, vai se consolidar também uma busca por melhorias dos produtos nacionais de maneira a concorrerem no mesmo patamar dos importados, o que corresponde a um amadurecimento do mercado gastronômico, em que o próprio tema vai assumir maior destaque.

Paralelamente, nota-se uma grande mudança nos hábitos de consumo, com itens como arroz e feijão sendo substituídos por outros gêneros dentro do domicilio, ao mesmo tempo em que vai se ampliando o hábito de comer fora de casa.

Deve-se relacionar esse momento ainda a uma nova realidade mundial, em que São Paulo reafirma sua importância, consolidando-se como uma cidade de caráter "global".

Nesse cenário de mercados transnacionais, o que também se verifica é que a facilidade de acesso, em qualquer parte do mundo, a produtos e serviços com características muito semelhantes, padronizados, faz emergir a busca por outros que sejam percebidos como singulares. A "sociedade de consumo" vai se deslocando na direção de uma "sociedade de experiências" na qual atributos territoriais e culturais serão destacados como marcas distintivas de produtos e até mesmo de localidades, criando uma realidade na qual a gastronomia ocupa um espaço altamente promissor.

Com maior visibilidade e a ampliação do mercado, crescem as possibilidades de realização e a responsabilidade dos profissionais do setor. Abre-se através de um mercado de luxo uma janela de valorização da diversidade de biomas e das pequenas produções, o que parece se constituir numa oportunidade única em um país cujas políticas costumam privilegiar a grande propriedade.

Isso porque, dialeticamente, a globalização que leva à uniformização também vai enaltecer o singular, o local. Assim, em São Paulo, o maior mercado de alimentação e principal polo gastronômico do país - aquele que dita tendências para 
todo o Brasil - observa-se uma exaltação do "local", que parece ser definido primordialmente em oposição àquilo que já foi consagrado como global e/ou exterior.

$\mathrm{Na}$ cidade, a noção de local se alarga, apropriando-se daquilo que possa ser referenciado como nacional, colocando São Paulo na condição de vitrine do Brasil. Mais do que isso, a torna o ponto de conexão entre o local e o global, oferecendo fragmentos do mundo para os brasileiros de todas as nacionalidades e alçando a gastronomia brasileira a um patamar de destaque internacional.

A dimensão continental do Brasil, a multiculturalidade de sua população, a primazia da cidade de São Paulo no contexto nacional associado ao seu grande poder de consumo e ao o crescente destaque no mercado internacional the conferem esta situação peculiar: congregar local e global no mesmo prato.

\section{Limitações do estudo}

Objetivando apresentar a pluralidade e o dinamismo da mesa paulistana, foram abordados alguns aspectos referentes às suas influências formativas no plano cultural e mudanças sociodemográficas que impactam o mercado de alimentos na cidade de São Paulo. Além disso, foram consolidados alguns entendimentos e percepções a respeito desse mercado com base em entrevistas realizadas com chefs/proprietários de restaurantes e jornalistas atuantes na área gastronômica, privilegiando-se, assim, a perspectiva dos restaurantes de destaque na cidade de São Paulo, aqueles que exercem maior influência na formação de sua imagem de polo gastronômico. Embora tenham sido tratados diversos aspectos nessas três vertentes, outros poderiam ter sido incluídos de maneira a consubstanciar uma visão mais ampla do assunto ou apresentar a temática por outro ângulo. Entre elas:

.. análise das diversas preparações que integram o cardápio do paulistano, dentro e fora do lar;

.. discussão sobre questões jurídicas que regem e impactam o setor, como as que determinam as restrições de importação;

.. investigação das percepções e entendimentos sobre o mercado de alimentação pelo âmbito dos consumidores ou de outros canais, como supermercados, padarias, bares e outras categorias de restaurante. 


\section{Sugestões para estudos futuros}

Este trabalho se apresenta como uma contribuição ao entendimento da mesa paulistana como um elemento plural e dinâmico dentro da sociedade, que articula o local e o global. A partir dele, uma série de outras pesquisas poderão ser desenvolvidas no sentido de ampliá-lo, aprofundá-lo e complementá-lo. Além daqueles que se caracterizam entre as limitações deste trabalho, seguem como sugestões:

.. aprofundar a discussão sobre o que se entende por comida paulistana dentro do contexto antropológico das identidades plurais.

.. desenvolver estudos que norteiem ações de fomento ao desenvolvimento econômico, social, cultural e ambiental em determinadas localidades, considerandose a integração de ingredientes e produtos gastronômicos locais a outros mercados. 


\section{REFERÊNCIAS}

AAKER, David A. et al. Pesquisa de marketing. 2. ed. São Paulo: Atlas, 2004.

AGÊNCIA BRASILEIRA DE PROMOÇÃO DE EXPORTAÇÃO E INVESTIMENTOS (APEX). Brasil busca aumentar exportação de produtos industrializados. Out. 2009. Disponível em: <http://www.apexbrasil.com.br/portal_apex/publicacao/engine. wsp?tmp. area $=27 \&$ tmp.texto=6280 $>$. Acesso em: mai. 2010.

ALENCASTRO, Luiz Felipe; RENAUX, Maria Luiza Caras e modos dos migrantes e imigrantes. In: NOVAIS, Fernando. (Org.). História da vida privada no Brasil. v. 2. São Paulo: Cia. das Letras, 1997. p. 291-335.

ALIMENTAÇÃO fora do lar. A evolução da alimentação fora do lar no Brasil. Ed. 2, nov. 2006. Disponível em: <http://www.alimentacaoforadolar.com.br/ conteudo_edicoes.asp? act=conteudo\&idconteudo $=129 \& p a g=104 \&$ edicao $=3>$.

Acesso em: out. 2010.

ALONSO, Andre Deak. Depende do ângulo. Educação, mar. 2002.

ALVIM, Zuleika Maria Forcione. O Brasil Italiano (1880-1920). In: FAUSTO, Boris. Fazer a América: a imigração em massa para a América Latina. São Paulo: Edusp, 2000. p. 383-418.

AMOURETTI, Marie-Claire. Cidades e campos gregos. In: FLANDRIN, Jean-Louis; MONTANARI, Massimo. História da alimentação. 4. ed. São Paulo: Estação Liberdade, 1998. p. 137-152.

ANUNCIATO, Ofélia Ramos. Ofélia, o sabor do Brasil. São Paulo: Melhoramentos, 1996.

ARAÚJO, Regina. Marchas e contramarchas da migração no Brasil. Disponível em: <http://www.moderna.com.br/moderna/didaticos/em/geografia/projensinogeo/ rumos/0030 >. Acesso em: jun. 2010.

ASFORA, Wanessa. Apício: história da incorporação de um livro de cozinha na Alta Idade Média (séculos VIII e IX). 2010. 261f. Tese (Doutorado) - Faculdade de Filosofia, Letras e Ciências Humanas da Universidade de São Paulo, São Paulo, 2010. 
ASSOCIAÇÃO BRASILEIRA DAS INDÚSTRIAS DA ALIMENTAÇÃO (ABIA). O mercado de food service no Brasil. Ago. 2010. Disponível em: <http://www.abia.org.br/ecopublall1.asp>. Acesso em: set. 2010.

ASSOCIAÇÃO BRASILEIRA DE BARES E RESTAURANTES. Guia Abrasel de bares e restaurantes. São Paulo, 2009.

ASSOCIAÇÃO BRASILEIRA DE SUPERMERCADOS (ABRAS). Números que impressionam. SuperHiper: ranking Abras, ano 36, n. 407, abr. 2010.

ASSOCIAÇÃO DOS PRODUTORES DE VINHO DO VALE DOS VINHEDOS APROVALE. Indicação de procedência. Disponível em: $<$ http://www.valedosvinhedos.com.br/principal2.htm>. Acesso em: jun. 2008.

ATALA, Milad Alexandre Mack. Entrevista concedida em dez. 2010.

BAENINGER, Rosana. São Paulo e suas migrações no final do século 20. São Paulo em Perspectiva, São Paulo, v. 19, n. 3, Set. 2005 . Disponível em: <http://www.scielo.br/scielo.php?script=sci_arttext\&pid=S010288392005000300008\& Ing=en\&nrm=iso >. Acesso em: jan. 2011.

BAER, Werner. A economia brasileira. São Paulo: Nobel, 2002.

BANCO CENTRAL DO BRASIL. Disponível em: < http://www.bcb.gov.br/>. Acesso em: out. 2010.

BARBER, Benjamin. Djihad versus Mcworld. Paris: Desclee de Brouwer, 1996.

BARBOSA, Lívia. Tendência da alimentação contemporânea. São Paulo: ESPM, 2006.

BARBOSA, Lívia et al. As tendências da alimentação. In: FEDERAÇÃO DAS INDÚSTRIAS DO ESTADO DE SÃO PAULO; INSTITUTO DE TECNOLOGIA DE ALIMENTOS. Brasil Food Trends 2020. São Paulo, 2010. p. 39-47.

BARBUY, Heloísa. A cidade-exposição: comércio e cosmopolitismo em São Paulo, 1860-1914. São Paulo: Edusp, 2006. 
BARROS, Paulo Barroso de. Entrevista concedida em nov. 2010.

BASSANEZI, Maria; SCOTT, Ana; BACELLAR, Carlos; TRUZZI, Oswaldo. Atlas da imigração internacional em São Paulo 1850-1850. São Paulo: Unesp, 2008.

BAUMAN, Zigmun. Identidade. Rio de Janeiro: Zahar, 2005.

BEOZZO, J. Oscar. Brasil: 500 anos de migrações. São Paulo: Paulinas, 1992.

BERQUÓ, Elza. Evolução demográfica no Brasil: um século de transformações. São Paulo: Companhia das Letras, 2001. p. 16-37.

BETTENCOURT, Carlos. Entrevista concedida em nov. 2010.

BIRCHAL, Sérgio de Oliveira. Empresa e indústria alimentícia no Brasil. Revista de Administração da FEAD-Minas, Belo Horizonte, v. 1, n. 2, jul./dez. 2004.

BLOCH, Marc. Apologie pour l'histoire ou métier d'historien. Cahier des Annales, 3. Paris: Armand Colin,1949.

BOSI, Alfredo. A dialética da comunicação. In: temas e situações. São Paulo: Ática, 1987. (Org.). Cultura brasileira:

BOURDIEU, Pierre. A distinção: crítica social do julgamento. Porto Alegre: Zouk, 2007.

BOURNE, Ursula. Portuguese cookery. Londres: Penguin, 1973.

Spanish cookery. Londres: Penguin, 1974.

BRESCIANI, Edda. Alimentos e bebidas do Antigo Egito. In: FLANDRIN, Jean-Louis; MONTANARI, Massimo (Org.). História da alimentação. 4. ed. São Paulo: Estação Liberdade, 1998. Cap. 3, p. 68-79. 
BRILLAT-SAVARIN, Jean-Anthelme. A fisiologia do gosto. São Paulo: Cia. das Letras, 1999.

CAMARGO, Luiz Américo. Entrevista concedida em nov. 2010.

CAMINHA, Pero Vaz. Carta de Pero Vaz de Caminha a El-Rei D. Manuel sobre o achamento do Brasil. Portugal: Publicações Europa-América, s.d.

CAMPOS FILHO, Cândido Malta. Cidades brasileiras: seu controle ou o caos. O que os cidadãos devem fazer para a humanização das cidades no Brasil. 4. ed. São Paulo: Studio Nobel, 2001.

CAPRA, Fritjof. As redes do capitalismo global: as conexões ocultas. São Paulo, Cultrix: 2002.

CARNEIRO, Henrique. Comida e sociedade: significados sociais na história da alimentação. In: ARAÚJO; Wilma Maria Coelho; TENSER; Carla Márcia Rodrigues. Gastronomia: cortes e recortes. Brasília: Senac, 2006.p. 137-161.

CAROSSELA, Paola. Entrevista concedida em set. 2010.

CARVALHO, Marcelo. O Alimento: do espaço privado à mercadoria. In: CORNELLI, Gabriele; MIRANDA, Danilo Santos de. (Org.). Cultura e alimentação: saberes alimentares e sabores culturais. São Paulo: Senac, 2007.

CARVALHO, Nuno Vieira de. Cultura urbana e globalização. Disponível em: <http://www.bocc.ubi.pt>. Acesso em: abr. 2010.

CASCUDO, Luis da Câmara. História da alimentação no Brasil. 3. ed. São Paulo: Global, 2004.

CASTANHO, Ricardo. Entrevista concedida em set. 2010.

CASTELLS, Manuel. A era da informação: economia, sociedade e cultura (A sociedade em rede). v. 1. São Paulo: Paz e Terra, 1999.

CASTILHO, Ricardo. Entrevista concedida em out. 2010. 
CASTRO, Josué de. A alimentação brasileira à luz da geografia humana. Porto Alegre: Edições Globo, 1937.

CAVALCANTI, Pedro. A pátria nas panelas: história e receitas da cozinha brasileira. São Paulo: Senac, 2007.

CENTRO DAS CULTURAS. Disponível em: <http://www.centrodasculturas.org.br/ atividades_grupo.htm>. Acesso em: ago. 2010.

CERTEAU, Michel; GIARD, Luce; MAYOL, Pierre. A invenção do cotidiano 2: morar, cozinhar. 6. ed. Petrópolis: Vozes, 2005. Cap. 7, p. 235-367.

CHAGAS, João. Viagem ao redor de um almoço. In: CASCUDO, Luís Câmara (Org.). Antologia da alimentação no Brasil. Rio de Janeiro: Livros Científicos Técnicos, 1977. p. 125-129.

CHAUNU, Pierre. L'expansion europeenne du $\mathrm{XII}^{\mathrm{e}}$ au $\mathrm{XV}^{\mathrm{e}}$ siècle. 3. ed. Paris: PUF, 1995.

COMER E BEBER: 2010-2011. Revista Veja São Paulo, São Paulo, ed. especial, n.14, 22 set. 2010. 538p. 2009. $498 p$.

.$:$ 2009-2010. Revista Veja São Paulo, São Paulo, ed. especial, n.13, 23 set.

COMPANHIA DE ENTREPOSTOS E ARMAZÉNS GERAIS DE SÃO PAULO (CEAGESP). Disponível em: <http://www.ceagesp.gov.br>. Acesso em: abr. 2010a. maio $2010 b$.

Dados enviados pela assessoria de imprensa e pelo setor de economia. 05

CONSELHO NACIONAL DA PECUÁRIA DE CORTE. Rebanho bovino brasileiro é o segundo maior do mundo. Nov. 2010. Disponível em: <http://www.cnpc.org.br/news1.php?ID=3057>. Acesso em: out. 2010.

CONSTANTIN, Paulo Dutra. Fatores condicionantes da produtividade agrícola no Brasil de 1970 a 2005: uma abordagem neoclássica. 2007. Tese (Doutorado) Universidade Presbiteriana Mackenzie, Programa de Pós-graduação em 
Administração de Empresas. Disponível em: <http://mx.mackenzie.com.br/tede/ tde_busca/arquivo.php?codArquivo=626>. Acesso em: ago. 2010.

COSTA, Antonio Carlos et al. A produção de alimentos. In: FIESP; IBOPE. Food Trends 2020. São Paulo, 2010a, p. 13-21.

; Fatores que influenciam o consumo de alimentos. In: FIESP; IBOPE. Food Trends 2020. São Paulo, 2010b, p. 23-37.

COSTA, Edgar Bueno da. Entrevista concedida em set. 2010.

COSTA, Iraci Del Neno da; NOZOE, Nelson Hedeiki; PORTO, Cornélia Nogueira. Transformações da estrutura produtiva agrícola e movimentos migratórios recentes no brasil. São Paulo: Seplam/Fipe, 1986.

COUTO, Cristiana. Arte de Cozinha: alimentação e dietética em Portugal e no Brasil (séculos XVII-XIX). São Paulo: Senac, 2007.

COZZOLINO, Silvia. M. F; FISBERG, Mauro; WHEBA, Jamal. Um, dois, feijão com arroz: a alimentação no Brasil de Norte a Sul. São Paulo: Atheneu, 2002.

CROMPTON, Rosemary. Class and estratification. Cambridge: Polity Press, 1993.

CUNHA, Altivo R. A. de Almeida; MACHADO, Moisés. Texto para discussão $\mathbf{n}$. 189: quem vende a cesta básica mais barato? (um abalo no mito da eficiência das grandes redes supermercadistas). Belo Horizonte: UFMG/-CEDEPLAR. 2003.

DA MATTA, Roberto. Notas sobre o racismo à brasileira. In: SOUZA, Jessé (Org.). Multiculturalismo e racismo: o papel da ação afirmativa nos Estados democráticos contemporâneos. Brasília: Ministério da Justiça, 1996.

DECOL, René D. Uma história oculta: a imigração dos países da Europa do CentroLeste para o Brasil. In: Anais do XII Encontro Nacional de Estudos populacionais da ABEP. Caxambu, 2000. Disponível em: <http://www.abep.nepo.unicamp.br/ docs/anais/pdf/2000/Todos/Uma\%20Hist\%C3\%B3ria\%20Oculta\%20a\%20Imigra\%C 3\%A7ao\%20dos\%20Pa\%C3\%ADses.pdf>. Acesso em: jun. 2010.

DEDALUS (Sistema de Bibliotecas Integradas da Universidade de São Paulo). Disponível 
<http://143.107.73.17:80/F/SQMG9PQHYN4NSUA1EIF2RTGL7QSXBTPV9ASRQJ5 2UD7UJBGKRH-39808?func=find-b\&request=globalizacao\&find_code=WRD\& adjacent=N\&local_base $=U S P 01 \& x=37 \& y=6 \&$ filter_code_1=WLN\&filter_request_1=\&f ilter_code_2=WYR\&filter_request_2=\&filter_code_3=WYR\&filter_request_3=\&filter_c ode_4=WMA\&filter_request_4=\&filter_code_5=WBA\&filter_request_5=2010>. Acesso em: mai. 2010.

DEPARTAMENTO NACIONAL DE TRÂNSITO (DENATRAN). Frota 2010. Disponível em: <http://www.denatran.gov.br/frota.htm>. Acesso em: jan. 2011.

DINIZ, Firmo de Albuquerque (Junius). Notas de viagem. v. 5. São Paulo: Governo do Estado de São Paulo, 1978.

DONNA, Enzo. O mercado de food service no Brasil. São Paulo, ECD Consultoria, Nov. 2010. 25 lâminas: color.

DÓRIA, Carlos Alberto. A formação da culinária brasileira. São Paulo: Publifolha, 2009a.

A culinária materialista. São Paulo: Senac, 2009b.

DURHAN, Eunice R. A caminho da cidade: a vida rural e a migração para São Paulo. São Paulo: Perspectiva, 1973.

ÉPOCA O MELHOR DE SÃO PAULO: 2009-2010. Revista Época São Paulo. São Paulo, n.19, nov. 2009.

ÉPOCA O MELHOR DE SÃO PAULO: 2010-2011. Revista Época São Paulo. São Paulo, n.29, set. 2010.

ERNST YOUNG; FUNDAÇÃO GETÚLIO VARGAS. Brasil sustentável: perspectivas do Brasil na agroindústria. 2009. Disponível em: <http://www.ey.com/Publication/vwLUAssets/Brasil_Sustentavel_-

Perspectivas_do_Brasil_na_Agroindustria/\$FILE/Brasil_Sustentavel_Perspectivas_ do_Brasil_na_Agroindustria.pdf $>$. Acesso em: mar. 2010.

ESTIMA, Camilla; PHILIPPI, Sonia; ALVARENGA, Marle. Fatores determinantes de consumo alimentar: por que os indivíduos comem o que comem? In: Revista Brasileira de Nutrição Clínica, n. 4, p. 263-8, dez. 2009. Disponível em: <http://www.sbnpe.com.br/revista/V24-N4-212.pdf>. Acesso em: abr. 2010. 
EXPANSÃO vigorosa. Valor Econômico, São Paulo, 15 dez. 2010. Disponível em: <http://www.valoronline.com.br/impresso/walmart/2096/352413/expansao-vigorosa>. Acesso em: dez. 2010.

FASANO, Fabrizio. Entrevista concedida em dez. 2010.

FAUSTO, Boris. História do Brasil. 8. ed. São Paulo: Edusp, 2000.

FEDERAÇÃO DAS INDÚSTRIAS DO ESTADO DE SÃO PAULO (FIESP); INSTITUTO BRASILEIRO DE OPINIÃO PÚBLICA E ESTATÍSTICA (IBOPE). Pesquisa Nacional Fiesp/lbope sobre o perfil do consumo de alimentos no Brasil. In: FEDERAÇÃO DAS INDÚSTRIAS DO ESTADO DE SÃO PAULO; INSTITUTO DE TECNOLOGIA DE ALIMENTOS. Brasil food trends. São Paulo, 2010. Cap. 4, p. 49-61.

FEDERAÇÃO DAS INDÚSTRIAS DO ESTADO DE SÃO PAULO (FIESP); INSTITUTO DE TECNOLOGIA DE ALIMENTOS (ITAL). Brasil food trends 2020. São Paulo, 2010.

FERNANDES, Caloca. A culinária paulista tradicional nos hotéis SENAC São Paulo. São Paulo: SENAC, 1998.

Viagem gastronômica através do Brasil. São Paulo: SENAC, 2000.

FERNANDES, Florestan. A integração do negro na sociedade de classes. 3. ed. São Paulo: Ática, 1978.

FISCHLER, Claude. El (h)omnívoro: el gusto, la cocina y el cuerpo. Barcelona: Amnagrama, 1995.

FLANDRIN, Jean-Louis. A humanização das condutas alimentares. In: MONTANARI, Massimo. História da alimentação. 4. ed. São Paulo: Estação Liberdade, 1998. p. 26-35.

Estação Liberdade, 1998.

MONTANARI, Massimo. História da alimentação. 4. ed. São Paulo: 
FOOD AND AGRICULTURE ORGANIZATION OF THE UNITED NATIONS (FAO). The State of Food and Agriculture. Roma, 2009. Disponível em: <http://www.fao.org/docrep/012/i0680e/i0680e00.htm>. Acesso em: set. 2010.

FRANCE, Marie. Entrevista concedida em out. 2010.

FRANCO, Ariovaldo. De caçador a gourmet: uma história da gastronomia. 4. ed. São Paulo: Senac, 2006.

FREITAS, Affonso A. de. Tradições e reminiscências paulistanas. São Paulo: Governo do Estado, 1978.

FREIXA, Dolores; CHAVES, Guta. Gastronomia no Brasil e no mundo. Rio de Janeiro: SENAC Nacional, 2008.

FREYRE, Giberto. Açúcar: uma sociologia do doce, com receitas de bolos e doces do Nordeste do Brasil. São Paulo: Companhia das Letras, 1997.

Casa Grande \& Senzala. 34. ed. Rio de Janeiro: Record, 1998.

FRIEDMAN, Jonathan. Global crises, the struggle for cultural identity and intellectual pork-barreling: cosmopolitans versus locals, ethnics and nationals in an era of dehegemonization. In: WERBNER, Pnina; MODOOD, Tariq. Debating Cultural Hibridity: multi-cultural identities and the politics of anti-racism. p.70-89. Londres: Zed Books, 1997.

FURTADO, Celso. Formação econômica do Brasil. 36. ed. São Paulo: Companhia das Letras, 2006.

GEOGRAFIA DE MERCADO. Disponível em: <http://www.geografiademercado. com.br/MapScapeV3/TacticianOnline/>. Acesso em: dez. 2010.

GIDDENS, Anthony. Runaway world: how globalization is reshaping our lives. Londres: Profile Books 1999.

GOMES, Angela de Castro. Imigrantes italianos: entre a italianitá e a brasilidade. In: Brasil: 500 anos de povoamento. Rio de Janeiro: IBGE, 2000. p. 159-177. 
GOMES, Sueli de Castro. O comércio do Brás e a inserção dos migrantes nacionais, asiáticos e latinos. Anais do $\mathbf{X}$ encontro de geógrafos da América Latina, Universidade de São Paulo, mar. 2005.

GONÇALVES, José Reginaldo Santos. A fome e o paladar: a antropologia nativa de Luís da Câmara Cascudo. Estudos Históricos, Rio de Janeiro, n. 33, p. 40-55, jan./jun. 2004.

GOWHERE Gastronomia. United Magazines, São Paulo, n. 38, 2010.

GRAY, John. The era of globalisation is over. Disponível em: <http://i-p-o.org/globalization-gray.htm>. Acesso em: abr. 2010.

GREGORY, Valdir. Imigração alemã: formação de uma comunidade teuto-brasileira. In: INSTITUTO BRASILEIRO DE GEOGRAFIA E ESTATÍSTICA. Brasil: 500 anos de povoamento. Rio de Janeiro: IBGE, 2000. p. 141-157.

GRÜN, Roberto. Construindo um lugar ao sol: os judeus no Brasil. In: FAUSTO, Boris. Fazer a América: a imigração em massa para a América Latina. São Paulo: Edusp, 2000.

GRUZINSKI, Serge. Virando séculos: 1480 - 1520. São Paulo: Cia das Letras, 1999.

GUIA DA FOLHA. O Melhor de São Paulo: Restaurantes \& Bares. Folha de São Paulo, 25 jun. 2010.

2009.

. O Melhor de São Paulo: Restaurantes \& Bares. Folha de São Paulo, 26 jun.

GUIA QUATRO RODAS. Brasil 2011. São Paulo: Abril, 2010. 946p.

. Brasil 2010. São Paulo: Abril, 2009.

. Brasil 2009. São Paulo: Abril, 2008.

. Brasil 2006. São Paulo: Abril, 2005. 962p. 
. Brasil 2001. São Paulo: Abril, 2000. 601p.

. Brasil 1996. São Paulo: Abril, 1995. 545p.

. Brasil 1990. São Paulo: Abril, 1989. 641p.

. Brasil 1986. São Paulo: Abril, 1985. 642p.

. Brasil 1981. São Paulo: Abril, 1980.610p.

Brasil 1976. São Paulo: Abril, 1975. 543p.

Brasil 1971. São Paulo: Abril, 1971. 418p.

. Brasil 1966. São Paulo: Abril, 1966. 322p.

GUIMARÃES, Lucia Maria P.; VAINFAS, Ronaldo. Sonhos galegos: 500 anos de espanhóis no Brasil. In: Brasil: 500 anos de povoamento. Rio de Janeiro: IBGE, 2000. p. 101-121.

GÜNTHER, H. Pesquisa qualitativa versus pesquisa quantitativa: esta é a questão? Psicologia: Teoria e Pesquisa, v. 22, n. 2, pp. 201-210, maio/ago., 2006 UnB.

HAIR JR, Joseph F. et al. Fundamentos de métodos de pesquisa em administração. Porto Alegre: Bookman, 2005b.

HALL, Michael Colins et al. Food tourism around the world - development, management and markets. Oxford: Butterworth Heinemann, 2003.

HALL, Stuart. A identidade cultural na pós-modernidade. 11. ed. Rio de Janeiro: DP\&A, 2006.

HANNERZ, Ulf. Fluxos, fronteiras, híbridos: palavras-chave da antropologia transnacional. Mana [online]. 1997, vol.3, n.1, pp. 7-39. ISSN 0104-9313. Disponível em: <http://www.scielo.br/pdf/mana/v3n1/2454.pdf>. Acesso em: mai. 2010. 
HARVEY, David. A arte de lucrar: globalização, monopólio e exploração da cultura. In: MORAES, Denis de. Por uma outra comunicação: mídia, mundialização, cultural e poder. Rio de Janeiro: Record, 2004.

HECK, Marina; BELUZZO, Rosa. Cozinha dos imigrantes: memórias e receitas. São Paulo: DBA Melhoramentos, 1999.

HELD, David et al. Global transformations. Stanford: Stanford University Press, 1999. Disponível em: < http://www.polity.co.uk/global/research.asp>. Acesso em: abr. 2010.

HERMANN, Jacqueline. Cenário de encontro dos povos: a construção do território. In: Brasil: 500 anos de povoamento. Rio de Janeiro: IBGE, 2000. p. 17-33.

HOGAN, Daniel J.; BERLINCK, Manoel T. O desenvolvimento econômico do Brasil e as imigrações internas para São Paulo: uma análise histórica. Campinas: Unicamp, 1974.

HOLANDA, Sérgio Buarque de. Raízes do Brasil. 26. ed. São Paulo: Companhia das Letras, 2010.

HOUAISS, Antonio. Minhas receitas brasileiras. São Paulo: Art, 1990.

HUNTINGTON, Samuel. The clash of civilizations?: the debate. Nova lorque: Foreign Affairs Summer, 1993. Disponível em: <http://history.club.fatih.edu.tr/ 103\%20Huntington\%20Clash\%20of\%20Civilizations\%20full\%20text.htm>. Acesso em: mai. 2010.

HUTTER, Lucy Maffeti. A imigração italiana em São Paulo em 1902-1914. O processo imigratório. São Paulo: CESP (Instituto de Estudos Brasileiros), 1986.

IBOPE. Disponível em: <http://www.ibope.com.br>. Acesso em: out. 2010.

IDONE, Christopher. Brasil: a cook's tour. Nova lorque: Clarkson N. Potter Inc., 1995.

IGLESIAS FILHO, Belarmino. Entrevista concedida em nov. 2010. 
INSTITUTO AKATU. Disponível em: <http://www.akatu.org.br>. Acesso em: jul. 2010.

INSTITUTO BRASILEIRO DE GEOGRAFIA E ESTATÍSTICA (IBGE). Censo 2010. 2010a. Disponível em: <http://www.ibge.gov.br/censo2010/primeiros_dados_ divulgados/index.php>. Acesso em: dez. 2010.

$2010 b$

Pesquisa de orçamentos familiares - 2008/2009. Rio de Janeiro: IBGE,

Pesquisa nacional por amostra de domicílios - 2009. Rio de Janeiro: IBGE, 2010c. Disponível em: <http://www.ibge.gov.br/home/estatistica/populacao/ trabalhoerendimento/pnad2009/default.shtm>. Acesso em: dez. 2010.

Produto interno bruto dos municípios :2004-2008. dez. 2010d. Disponível em: <http://www.ibge.gov.br/home/presidencia/noticias/noticia_ visualiza.php?id_noticia=1780\&id_pagina=1 >. Acesso em: dez. 2010.

Síntese de indicadores sociais: uma análise das condições de vida da população brasileira. Rio de Janeiro: IBGE, 2010e (Estudos e pesquisas informação demográfica e socioeconômica, n. 27).

Em 2008, esperança de vida dos brasileiros chega a 72,86 anos. dez. 2009a. Disponível em:<http://www.ibge.gov.br/home/presidencia/noticias/noticia visualiza.php?id_noticia=1507\&id_pagina=1 >. Acesso em: mai. 2010.

Estatísticas do século XX. Rio de Janeiro: IBGE, 2006. Disponível em: <http://www.ibge.gov.br/seculoxx/seculoxx.pdf>. Acesso em: jan. 2011.

2004.

Pesquisa de orçamentos familiares - 2002/2003. Rio de Janeiro: IBGE,

Brasil: 500 anos de povoamento. Rio de Janeiro: IBGE, 2000.

Censo 2000. Rio de Janeiro: IBGE, 2001. Disponível em: <http://www.ibge.

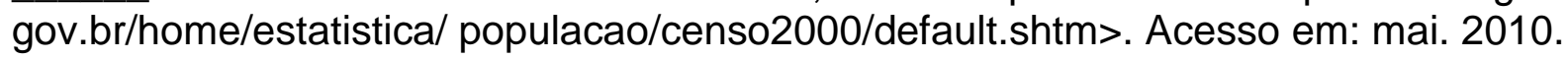


Pesquisa de orçamentos familiares 1995/1996. Rio de Janeiro: IBGE, 1997. Disponível em: <http://www.ibge.gov.br/home/estatistica/populacao/ condicaodevida/pof/defaulttab.shtm>. Acesso em: mar. 2010.

- Estatísticas históricas do Brasil: Séries Econômicas, Demográficas e Sociais de 1550 a 1985. Rio de Janeiro: IBGE, 1987.

Pesquisa de orçamentos familiares - 1987/1988. Rio de Janeiro: IBGE, 1991. Disponível em: <http://www.sidra.ibge.gov.br/bda/tabela/listabl.asp?c=400\&z $=p \& 0=16>$. Acesso em: jul. 2010.

1978.

. Estudo nacional da despesa familiar - 1974/1975. Rio de Janeiro: IBGE,

INSTITUTO DE PESQUISA ECONÔMICA APLICADA (IPEA). Radar: tecnologia, produção e comércio exterior $n$. 7 . Disponível em: <http://agencia.ipea.gov.br/images/stories/PDFs/100428_radar07.pdf>. Acesso: mai. 2010.

INSTITUTO NACIONAL DA PROPRIEDADE INDUSTRIAL (INPI). O que é indicação geográfica? 2010. Disponível em: <http://www.inpi.gov.br/menuesquerdo/indicacao/o-que-e-indicacao-geografica>. Acesso em: abr. 2010.

ISHIGE, Naomichi. O homem, o comensal. O Correio, São Paulo, ano 15, s. n., p. 18-23, jul. 1987.

JACQUIN, Erick. Entrevista concedida em out. 2010.

JOANNĖS, Francis. A função social do banquete nas primeiras civilizações. In: FLANDRIN, Jean-Louis; MONTANARI, Massimo. História da alimentação. 4. ed. São Paulo: Estação Liberdade, 1998. Cap. 2, p. 54-67.

KLEIN, Herbert S. Migração internacional na história das Américas. In: FAUSTO, Boris (Org.). Fazer a América. A imigração em massa para a América Latina. São Paulo: Edusp, 2000. p. 13-32.

KODAMA, Kaori. O sol nascente do Brasil: um balanço da imigração japonesa. In: Brasil: 500 anos de povoamento. Rio de Janeiro: IBGE, 2000. p. 197-213. 
KOPYTOFF, Igor. The cultural biography of things: commoditization as process. In: APPADURAI, Arjun. The social life of things. Cambridge: Cambridge University Press, 1986. p. 64-94.

KUCZYNSKI, Sérgio. Entrevista concedida em set. 2010.

KUCZYNSKI, Leila Youssef. Larousse da cozinha do mundo: Oriente Médio, África e Índico. São Paulo: Larousse do Brasil, 1995.

LANCELOTTI, Sílvio. $\mathbf{5 0 0}$ anos de gastronomia em Terra Brasilis. Porto Alegre: L\&PM, 2000.

LANDIM, Raquel. Brasil já é o terceiro maior exportador agrícola do mundo. 0 Estado de São Paulo. Mar. 2010. Disponível em: <http://www.estadao.com.br/noticias/economia,brasil-ja-e-o-terceiro-maiorexportador-agricola-do-mundo,520500,0.htm>. Acesso em: mai. 2010.

LATOUCHE, Serge. The westernization of the world. Cambridge (UK): Polity Press, 2006.

LAUDAN, Rachel. Birth of the modern diet. Scientific American, p. 76-81, Aug. 2000.

LAZZARINI, Silvio. Entrevista concedida em set. 2010.

LEITE, Joaquim da Costa. O Brasil e a emigração portuguesa (1855-1914). In: FAUSTO, Boris (Org.). Fazer a América: a imigração em massa para a América Latina. São Paulo: Edusp, 2000. p. 177-200.

LEONARD, William R. Food for thought: dietary change was a driving force in human evolution. Scientific American, n. 6, p. 106-115, Dec. 2002.

LÉVI-STRAUSS, Claude. Le triangle culinaire. Le nouvel observauter hors -série, p. 14-17, Nov./Déc. 2009. Disponível em: <http://www.palimpsestes.fr/ textes_philo/levi_strauss/triangle_culinaire.pdf>. Acesso em: dez. 2010.

O cru e o cozido. São Paulo: Cosac \& Naif, 2004. v. 1. 
LIBRARIE LAROUSSE. Larousse gastronomique. França: Librarie Larrousse, 1984.

LIMA, Cláudia. Tachos e panelas: historiografia da alimentação brasileira. 2. ed. Recife: Editora da Autora, 1999.

LISBOA. Directorio que se deve observar nas povoaçoens dos indios do Pará, e Maranhão em quanto Sua Magestade não mandar o contrário. In: 1758. Cambridge: Harvard College Library, 1924.

LOPES, Dias. Itália vai à luta para salvar "la vera cucina". O Estado de São Paulo, São Paulo, Paladar, 10 jun. 2010. Disponível em: <http://www.estadao.com.br/noticias/suplementos+paladar, italia-vai-a-luta-parasalvar-la-vera-cucina,3802,0.shtm>. Acesso em: jan. 2011.

LORENÇATO, Arnaldo. Entrevista concedida em dez. 2010.

LUCKI, Jorge. A experiência do gosto. São Paulo: Companhia das Letras, 2010.

MACIEL, Maria Eunice. Uma cozinha à brasileira. Estudos Históricos, Rio de Janeiro, n. 33, p. 25-34, jan./jun. 2004.

MALHOTRA, Naresh. Pesquisa de marketing: uma orientação aplicada. 4. ed. Porto Alegre: Bookman, 2006.

MARTÍNEZ, Elda Evangelina González. O Brasil como país de destino para os migrantes espanhóis. In: FAUSTO, Boris. Fazer a América: a imigração em massa para a América Latina. São Paulo: Edusp, 2000. p. 239-272.

MARTINEZ, Marina. Estereótipo. Jul. 2010. Disponível em: <http://www.infoescola.com/sociologialestereotipo>. Acesso em: fev. 2010.

MARTINS, Thales. Entrevista concedida em out. 2010.

MASANO, Tadeu Francisco. Os shopping centers e suas relações físicoterritoriais e sócio-negociais no município de São Paulo. 1993. Tese (Doutorado) - Faculdade de Arquitetura e Urbanismo da Universidade de São Paulo, São Paulo, 1993. 
MASANO, Tadeu Francisco. Localização de supermercados e o comportamento do consumidor: estudo de caso em São José do Rio Preto. 1984. Dissertação (Mestrado) - Faculdade de Economia e Administração da Universidade de São Paulo, São Paulo, 1984.

MATTAR, Fauze N. Pesquisa de marketing: edição compacta. 3. ed. São Paulo: Atlas, 2001.

MAUSS, Marcel. Da dádiva e, em particular da obrigação de retribuir presentes. Introdução IN: MAUSS, Marcel, Sociologia e antropologia. v. 2. São Paulo: EDUSP, 1974.

MEDEIROS, Esther dos Santos. O Brasil como país de destino para imigrantes. Resenha do texto de Elda Evangelina González Martínez em Fazer a América. São Paulo, 2005.

MEGIDO, José. A Comunicação In: ZYLBERSTAJN, Décio; NEVES, Marcos F. (Orgs.). Economia e gestão dos negócios agroalimentares: indústria de alimentos, indústria de insumos, produção agropecuária, distribuição. São Paulo: Pioneira, 2000.

MELLÃO, Hamilton. Entrevista concedida em out. 2010.

MELO, Josimar. Guia Josimar 2010. São Paulo: DBA, 2010. 303p.

. Guia Josimar Melo 2009. São Paulo: DBA, 2009. 351p.

. Entrevista concedida em nov. 2010.

; MARANHÃO, Ricardo. Gosto local evoluiu do beiju com torresmo para a cozinha de padrão internacional. Folha de São Paulo, Especial Comida, 28 nov. 2003. Disponível em: <http://www1.folha.uol.com.br/fsp/especial/fj2811200311.htm>. Acesso em: jan. 2011.

MEMORIAL DO IMIGRANTE. Disponível em: <http://www.memorialdoimigrante. org.br>. Acesso em: jun. 2010. 
MENESES, Ulpiano T. B.; CARNEIRO, Henrique. A história da alimentação: balizas historiográficas. história e cultura material. Anais do Museu Paulista. Nova série. v. 5. São Paulo: USP, 1997. p. 9-91.

MERCADO MUNICIPAL. Institucional. Disponível em: <http://www.mercadomunicipal.com.br/>. Acesso em: out. 2010.

MINISTÉRIO DO TRABALHO E DO EMPREGO. Estatísticas. Disponível em: $<$ http://www.mte.gov.br/geral/estatisticas.asp?viewarea=caged>. Acesso em: jan. 2011.

MIRANDA, Evaristo Eduardo. A invenção do Brasil. National Geographic, mai. 2007. p. 60-71.

MITTELMAN, James. The globalization syndrome. Princeton: Princeton University Press, 2000.

MÓL DE ARAÚJO, Blandine et al. Árabes: vozes do oriente. Disponível em: <http://www.etni-cidade.net/vozes_do_oriente.htm>. Acesso em: dez. 2010.

MONTANARI, Massimo. O mundo na cozinha. São Paulo: SENAC, 2009a.

. Radici e Tecnologie: l'insegnamento della storia. São Paulo: SENAC, 2009b. 50 lâminas: color.

. Comida como cultura. São Paulo: SENAC, 2008.

. Sistemas alimentares e modelos de civilização. In: FLANDRIN, Jean-Louis; MONTANARI, Massimo. História da alimentação. 4. ed. São Paulo: Estação Liberdade, 1998. p. 108-120.

MONTEIRO, John M. Alforrias, litígios e a desagregação da escravidão indígena em São Paulo. Revista de História, São Paulo, n. 120, p. 45-57, jul. 1989.

MORAES, Denis de. Por uma outra comunicação: mídia, mundialização, cultural e poder. Rio de Janeiro: Record, 2004. 
MORAIS, Célia Márcia Medeiros de; SILVA, Vanuska Lima da. Rio Grande do Norte. In: COZZOLINO, Silvia. M. F. et al. Um, dois, feijão com arroz: a alimentação no Brasil de Norte a Sul. São Paulo: Atheneu, 2002.

MOTT, Maria Lucia. Imigração árabe: um certo oriente no Brasil. In:INSTITUTO BRASILEIRO DE GEOGRAFIA E ESTATÍSTICA; Brasil: 500 anos de povoamento. Rio de Janeiro: IBGE, 2000. p. 179-195.

MOURA, Clóvis. História do negro brasileiro. São Paulo: Ática, 1989.

MURAKAMI, Tushioshi. Entrevista concedida em set. 2010

MUSZYNSKI, Maria Judith B. O impacto poético das migrações internas: o caso de São Paulo (1945-1982). São Paulo: Idesp, 1986.

MYAMURA, Flávio. Entrevista concedida em set. 2010.

MYIOSHI, Masao. Globalization, culture and the university. In: FREDRIC, Jameson; MYIOSHI, Masao. The cultures of globalization. Duke University Press, 1998. p. 247-272.

NILSEN; GEOGRAFIA DE MERCADO. Geoconnection. Disponível em: <http://www.geografiademercado.com.br/mapscapev3/TacticianOnline/products/geoc onnection.asp>. Acesso em: out. 2010.

NÓBREGA, Ricardo; DAFLON, Vêronica Toste. Da escravidão às migrações: raça e etnicidade nas relações de trabalho no Brasil. Latin America Studies Association, 2009. Disponível em: $<$ http://lasa.international.pitt.edu/members/congress-

papers/lasa2009/files/NobregaRicardo.pdf>. Acesso em: out. 2010.

NOSSITER, Jonathan. Gosto e poder: vinho, cinema e a busca dos prazeres. São Paulo: Companhia das Letras, 2009.

NUCCI, Celso. Guia da Boa Mesa. 1986. 535p

OLIVEIRA, Débora Santos de Souza. A transmissão do conhecimento culinário no brasil urbano do Século XX. 2010. 182f. Dissertação (Mestrado em História Social) - Faculdade de Filosofia, Letras e Ciências Humanas da Universidade de São Paulo, São Paulo, 2010. 
OLIVEIRA, Lúcia Lippi. O Brasil dos Imigrantes. 2. ed. Rio de Janeiro: Jorge Zahar Ed., 2002.

ORGANIZAÇÃO DAS NAÇÕES UNIDAS (ONU). World population prospects: the 2008 revision. 2009. Disponível em: <http://esa.un.org/unpp/>. Acesso em: jan. 2011.

ORTIZ, Renato. Cultura brasileira \& identidade nacional. São Paulo: Brasiliense, 2006.

OWENSBY, Brian P. Intimate ironies: modernity and the making of middle-class lives in Brazil. California: Stanford University Press, 1999.

PERILLO, Sônia. Novos caminhos da migração no Estado de São Paulo. São Paulo em Perspectiva, São Paulo, v.10, n.2, fev. 1996. Disponível em: < http://www.seade.gov.br/produtos/spp/v10n02/v10n02.pdf>. Acesso em: jan. 2011.

PERLÉS, Catherine. As estratégias alimentares nos tempos pré-históricos. In: FLANDRIN, Jean-Louis; MONTANARI, Massimo. História da alimentação. 4. ed., cap. 1, p. 36-53. São Paulo: Estação Liberdade, 1998.

PIETERSE, Jan Nederveen. Globalization and Culture: global mélange. 2. ed. Versão Kindle (Amazon), 2007.

PINTO, Carla Barboza. Brazilian cooking. Nova Jersey: Chartwell Books, 1998. PISTER, Olinda. Entrevista concedida em dez. 2010.

PODANOVSKI, João. São Paulo: Capital Gastronômica. São Paulo: Sindicato de Hotéis, Restaurantes, Bares e Similares de São Paulo, 1988.

POKHLIOBKIN, W. V. Cozinha tradicional dos povos da URSS. Moscou: Mir Moscova, 1989.

POULAIN, Jean-Pierre. Sociologias da alimentação. Florianópolis: UFSC, 2004.

PREFEITURA DE SÃO PAULO. Feiras livres: onde encontrar. Disponível em: $<$ http://www.prefeitura.sp.gov.br/cidade/secretarias/subprefeituras/abastecimento/feir as_livres/onde_encontrar/index.php?p=16601 >. Acesso em: 2010a. 
Histórico demográfico do município de São Paulo. Disponível em: <http://smdu.prefeitura.sp.gov.br/historico_demografico/1900.php>. Acesso em: ago. 2010b.

Relação dos mercados municipais. Disponível em: <http://www.prefeitura.sp.gov.br/cidade/secretarias/subprefeituras/abastecimento/me rcados_municipais_e_sacoloes/unidades/mercados/index.php? $p=4207>$. Acesso em: dez. 2010c.

PROJETO IMIGRANTES. Um pouco de história. Disponível em: <http://www.projetoimigrantes.com.br/int.php?dest=quem>. Acesso em: set. 2010.

PROJETO LUPA. Disponível em: <http://www.cati.sp.gov.br/projetolupa>. Acesso em: mai. 2010.

REIS, João José. A presença negra: encontros e conflitos. In: Brasil: 500 anos de povoamento. Rio de Janeiro: IBGE, 2000. p. 79-99.

REIS, Rossana Rocha; SALES, Teresa (Org.). Cenas do Brasil migrante. São Paulo: Boitempo, 1999.

RIBEIRO, Darcy. O povo brasileiro: a formação e o sentido do Brasil. 2. ed. São Paulo: Companhia Das Letras, 2003.

RIOS, José Maria. Entrevista concedida em dez. 2010.

RITZER, George. McDonaldization of the society. Newbury Park: Pine Forge Press, 2000.

RIZZO, Helena, Entrevista concedida em out. 2010.

ROBERTSON, Robbie. Three waves of globalization. Londres: Zed Books, 2004.

ROBERTSON, Roland. Globalization: Social Theory and global culture. London: sage, 1992. 
ROCHA, Ilana Peliciari. Imigração internacional em São Paulo: retorno e reimigração, 1890-1920. São Paulo, 2007.

ROMIO, Eda. Brasil 1500/2000: 500 anos de sabor. São Paulo: ER Comunicações, 2000.

ROSSI JÚNIOR, José Luiz; FERREIRA, Pedro Cavalcanti. Evolução da produtividade industrial brasileira e abertura de comercial. Rio de Janeiro: Instituto de Pesquisa Econômica Aplicada (IPEA), 1998.

SAITÕ, Hiroshi; MAEYAMA, Takashi. Assimilação e integração dos japoneses no Brasil. São Paulo: Editora da Universidade de São Paulo, 1973.

SAKAMOTO, Leonardo Jun. Entrevista concedida em nov. 2010.

SAKURAI, Célia. Imigração tutelada: os japoneses no Brasil. Campinas, 2000. Tese (Doutorado em Ciências Sociais) - Instituto de Filosofia e Ciências Humanas, Universidade Estadual de Campinas, 2000.

SALLUM, Erika et al. O que o nosso cardápio seria sem eles? Revista Veja São Paulo, São Paulo, ano 36, n. 16, p. 12-30, 5 fev. 2003.

SANTOMAURO; Antonio Carlos. Indústria de Alimentos. SuperHiper Panorama, ano 5, 2011. p. 76-104.

SANTOS, Carlos Roberto A. A alimentação e seu lugar na história: os tempos da memória gustativa. História: Questões \& Debates, Curitiba, n. 42, p. 11-31, Editora UFPR. 2005.

SANTOS, Milton; SILVEIRA, Maria Laura. O Brasil: território e sociedade no início do século XXI. 5. ed. Rio de Janeiro: Record, 2003.

Por uma outra globalização: do pensamento único à consciência universal. Rio de Janeiro: Record, 2000.

SASSEN, Saskia. As cidades na economia mundial. São Paulo: Nobel, 1998. 
SCHLOSSER, Eric. País fast food: o lado nocivo da comida norte-americana. São Paulo: Ática, 2001.

SCHLUTER, Regina. Gastronomia e turismo. São Paulo: Aleph, 2003.

SCHWARCZ, Lilia Moritz. Prefácio. In: SILVA, Paula Pinto e. Farinha, feijão e carne-seca: Um tripé culinário no Brasil colonial. 2. ed. São Paulo: Senac, 2010.

SCOTT, A. et al. Cidades regiões globais. In: Espaço \& Debates. v. 41. São Paulo: Neru, 2001.

SECRETARIA DE ECONOMIA E PLANEJAMENTO. Trabalho e desilgualdades de gênero na região metropolitana de São Paulo. Mulher e Trabalho, São Paulo, n. 21, mar. 2010.

SERVIÇO NACIONAL DE APRENDIZAGEM COMERCIAL. A história da gastronomia. Rio de Janeiro: SENAC, 1998.

SEYFERTH, Giralda. A colonização alemã no Brasil: etnicidade e conflito. In: FAUSTO, Boris (Org.). Fazer a América: a imigração em massa para a América Latina. São Paulo: Edusp, 2000. p. 273-313.

Colonização, Imigração e a Questão Racial no Brasil. Revista USP, n. 53, $\overline{\text { p.117-149, mar./maio } 2002 .}$

SHESHABALAYA, Ashutosh. The three rounds of globalization. 19. out. 2006.Disponível em: <http://www.globalpolicy.org/component/content/article/162general/27648-the-three-rounds-of-globalization.html>. Acesso em: mai. 2010.

SILVA, João Luiz Maximo da. Alimentação de rua na cidade de São Paulo (18281900). 2008. 246f. Tese (Doutorado) - Faculdade de Filosofia, Letras e Ciências Humanas da Universidade de São Paulo, São Paulo, 2008.

SILVA, Joselis Moreira da; PAULA, Nilson Maciel de. Alterações no padrão de consumo de alimentos no Brasil após o plano real. 2003. Disponível em: $<$ http://www.peteconomia.ufpr.br/banco_de_arquivos/00015_artigo\%20evinvi\%20Joselis.pdf>. Acesso em: mai. 2010. 
SILVA, Paula Pinto e. Farinha, feijão e carne-seca: Um tripé culinário no Brasil colonial. 2. ed. São Paulo: Senac, 2010.

SINGER, P. Migrações Internas: considerações teóricas sobre seu estudo. In: . Economia política da urbanização. São Paulo: Brasiliense, 1973.

SOLER, Jean. As razões da Bíblia: regras alimentares hebraicas.. In:FLANDRIN, Jean-Louis; MONTANARI, Massimo. História da alimentação. 4. ed., cap. 4, p. 8091. São Paulo: Estação Liberdade, 1998.

SOLIZ, Neusa. As diferentes fases da imigração alemã no Brasil. Maio 2004a. Disponível em: <http://www.dw-world.de/dw/article/0,,1195367_page_1,00.html>. Acesso em: ago. 2010.

Alemães ajudaram a formar a classe média paulistana. Maio 2004. Disponível em:<http://www.dw-world.de/dw/article/0,,1213337,00.html>. Acesso em: ago. 2010.

SOPEXA (Conseil en communication \& marketing alimentaire). Local flavour: a tour of french origin-linked products. Paris: Hachette, 2009.

SPANG, Rebecca. A invenção do restaurante. Rio de Janeiro: Record, 2003.

SOUZA, Itamar de. Migrações internas no Brasil. São Paulo: Vozes,1980?

SOUZA, Marina de Mello e. África e Brasil africano. 2. ed. São Paulo: Ática, 2007.

STEAGALL-GOMES, Daisy Leslie; MENDES, Iranilde José Messias. A força de trabalho da mulher. Acta paulista de enfermagem, São Paulo, v. 8, n. 1, p. 61-64, jan./abr. 1995.

STEGER, Manfred. Globalization: very short introduction. Oxford University Press. Versão Kindle, 2009.

STEINGARTEN, Jeffrey. O homem que comeu de tudo: feitos gastronômicos. São Paulo: Companhia das Letras, 2000. 
STILMAN, Meyer. O comércio varejista e os supermercados na cidade de São Paulo. São Paulo: Faculdade de Ciências Econômicas e Administrativas da USP, 1962.

SUPERMERCADO MODERNO. v. 15, n. 5, ago. 1983.

TALBOTT, Peters Shannon. Analysis of corporate culture in the global marketplace: case study of McDonald's in Moscow. Trabalho apresentado no International Institute of Sociology Conference, Trieste, 1995.

THERY. Hervé; MELLO, Neli Aparecida de. Atlas do Brasil. São Paulo: Edusp, 2005.

THIS, Hervé. Réflexion sur Le gôut. In: Repère pour la formation, CAP Cuisine, mai 2005. p. 8.

TOURINHO, Andréa de Oliveira. Centro e Centralidade: uma questão recente. In: Geografia das metrópoles. OLIVEIRA, Ariovaldo Umbelino; CARLOS, Ana Fani Alessandri (Orgs.). São Paulo: Contexto, 2006. p. 277-299.

TRAJANO, Ana Luiza. Brasil a gosto. São Paulo: Melhoramentos, 2005. . Entrevista concedida em out. 2010.

TREINTA, Rufino Casal. Entrevista concedida em jan. 2011.

TRENTO, Ângelo. Do outro lado do atlântico: um século de imigração italiana no Brasil. São Paulo: Nobel, 1988.

TRUZZI, Osvaldo. Sírios e libaneses e seus descendentes na sociedade paulista In: FAUSTO, Boris. Fazer a América: a imigração em massa para a América Latina. São Paulo: Edusp, 2000. p. 315-352.

UNIVERSIDADE DE BRASÍLIA (UNB). Alimentação e cultura. Disponível em: $<$ http://www.turminha.mpf.gov.br/para-o-professor/para-oprofessor/publicacoes/Alimentacaoecultura.pdf>. Acesso em: jun. 2010. 
VAINFAS, Ronaldo. História indígena: 500 anos de despovoamento. In: Brasil: 500 anos de povoamento. Rio de Janeiro: IBGE, 2000. p. 35-59.

VARGAS, Heliana Comin. Turismo e valorização do lugar. In: Turismo em Análise. Eca-Usp, São Paulo, v. 9, n. 1, p. 7-19, maio, 1998.

VEIGA, Aida. Mistura muita fina. Revista Veja, São Paulo, 1999. Disponível em: <http://veja.abril.com.br/170299/p_054.html>. Acesso em: abr. 2010.

VENÂNCIO, Renato P. Presença portuguesa: de colonizadores a imigrantes. In: INSTITUTO BRASILEIRO DE GEOGRAFIA E ESTATISTICA. Brasil: 500 anos de povoamento. Rio de Janeiro: IBGE, 2000. p. 60-77.

VERSIANI, Flávio Rabelo. Imigrantes, trabalho qualificado e industrialização: Rio e São Paulo no início do século. Revista de Economia Política, v. 13, n. 4, out./dez. 1993.

.; VERSIANI, Maria Teresa. A industrialização brasileira antes de 1930: uma contribuição. Estudos Econômicos, v. 5, n. 1, 1975.

VIANA, Marco Túlio. O que é isso companheiro? Associação Nacional dos Magistrados da Justiça do Trabalho (Anamatra). Disponível em: $<$ http://www.anamatra.org.br/customtags/impressao.cfm?cod_conteudo=3995\&servic o=artigos $>$. Acesso em: ago. 2010.

VILLALTA, Luiz Carlos. A educação na colônia e os jesuítas: discutindo alguns mitos. In: PRADO, Maria Ligia; VIIDAL, Diana Gonçalves. À margem dos 500 anos: reflexões irreverentes. São Paulo: EDUSP, 2002. p. 171-184.

WATERS, Malcon. Globalization. 2. ed. Oxford: Routledge, 2001.

WATSON, James. China's Big Mac Attack. In: ; CALDWELL, Melissa. The cultural politics of food and eating. 4. ed. Oxford: Blacwell Publishing, 2007.

WEICHERT, Márcio. São Paulo celebra 180 anos da imigração alemã. Jun. 2009. Disponível em: <http://www.dw-world.de/dw/article/0,,4411676,00.html>. Acesso em: mar. 2010. 
WEIS, Robert G. De panzas y prejuicios: la historia y la comida. Revista de História Iberoamericana, v. 2, n. 2, p. 10-15, 2009. Disponível em: <http://revistahistoria.universia.net/articulo/100/[ARTICULO]-PANZAS-REJUICIOSHISTORIA-COMIDA.html>. Acesso em: jul. 2010.

ZAMONER, Tatiana. Feiras livres. Trabalho de iniciação científica realizado para a Faculdade de Arquitetura e urbanismo sob a orientação da professora doutora Heliana Comin Vargas, 2002.

ZUURBIER, Peter. Cadeias de suprimento nos mercados internacionais. In: ZYLBERSZTAJN , Decio; NEVES Marcos Fava (Orgs.). Economia e gestão dos negócios agroalimentares. São Paulo: Thomson Pioneira, 2000. p. 403-415.

ZYLBERSZTAJN, Decio. Conceitos gerais, evolução e apresentação do sistema agroindustrial. In: ; NEVES, Marcos (Orgs.). Economia e gestão dos negócios agroalimentares. São Paulo: Thomson Pioneira, 2000. p. 1-20. 


\section{APÊNDICE A: METODOLOGIA DA PESQUISA DE CAMPO}

Este apêndice objetiva apresentar a tipologia de pesquisa utilizada para o trabalho de campo, bem como caracterizar o público-alvo entrevistado, isto é, chefs e proprietários de restaurantes e jornalistas especializados.

\section{A.1 Definição do tipo de pesquisa}

A definição do tipo de pesquisa a ser aplicado decorre dos objetivos do estudo e dos referenciais disponíveis ao pesquisador. De acordo com Malhotra (2006, p. 77), pesquisa é sempre um processo de múltiplas etapas, iniciado pela definição de um problema e finalizado com a apresentação de um relatório, fruto das análises dos dados coletados. A partir da especificação do que é necessário para responder ao objetivo delimitado, o pesquisador determina as informações que devem ser obtidas no projeto de pesquisa.

Mattar (2001, p. 18) classifica os métodos de pesquisa em duas grandes categorias: (i) exploratórias e (ii) conclusivas, sendo que esta última desdobra-se em pesquisas descritivas e pesquisas causais. O Quadro 3 apresenta as diferenças entre pesquisa exploratória e conclusiva.

\begin{tabular}{|l|l|}
\hline \multicolumn{1}{|c|}{ Pesquisa Exploratória } & \multicolumn{1}{c|}{ Pesquisa Conclusiva } \\
\hline Objetiva prover critérios e compreensão & Objetiva testar hipóteses e examinar relações \\
\hline As informações são fornecidas de forma ampla & As informações necessárias são claramente definidas \\
\hline O processo de pesquisa é não-estruturado & O processo de pesquisa é formal e estruturado \\
\hline A amostra é simples e não representativa & A amostra é ampla e representativa \\
\hline A análise dos dados primários é qualitativa & A análise de dados é quantitativa \\
\hline
\end{tabular}

Quadro 3: Pesquisa exploratória e Pesquisa conclusiva

Fonte: Adaptado de Malhotra (2006, p. 99). 
Para Aaker et al. (2004), o principal objetivo da pesquisa exploratória é ajudar o pesquisador a explorar o problema em busca de maior compreensão. A pesquisa exploratória é utilizada para as finalidades relacionadas a seguir:

- Formular um problema ou defini-lo com maior precisão;

- Identificar cursos alternativos de ação;

- Desenvolver hipóteses;

- Isolar variáveis e relações-chave para exame posterior;

- Obter critérios para desenvolver uma abordagem de problema;

- Estabelecer prioridades para pesquisas posteriores.

Complementarmente, a pesquisa descritiva objetiva descrever características e comportamentos de uma dada população, sendo realizada frequentemente para:

- Descrever características de populações ou grupos relevantes;

- Estimar porcentagem de uma população específica que exibe determinado comportamento;

- Determinar percepções de um determinado grupo;

- Determinar em que grau estão associadas as variáveis do estudo;

- Fazer previsões.

A pesquisa exploratória é aplicada quando as questões de pesquisa são carentes de teoria que possa nortear previsões; além disso, quando as informações à disposição do pesquisador são limitadas. Caracterizada pela versatilidade, a pesquisa exploratória raramente envolve questionário estruturado: o pesquisador está em busca de ideias e percepções e pode alterar e ajustar sua investigação à medida que recebe novas informações. "A pesquisa qualitativa proporciona melhor visão e compreensão do problema enquanto a pesquisa quantitativa busca quantificar os dados e, normalmente, aplica análises estatísticas" (MALHOTRA, 2006, p. 155).

As pesquisas qualitativas são, por natureza, exploratórias, pois devem estimular os entrevistados a pensarem livremente sobre algum tema, objeto ou conceito, propiciando emergir aspectos subjetivos e atingir motivações não explícitas de maneira espontânea. São usadas quando há busca por percepções e entendimentos sobre a natureza geral de uma questão, abrindo espaço para a interpretação. 
Flick e cols. (2000) apud Günther (2006, p. 202) enaltecem o fato de a pesquisa qualitativa ser caracterizada por um espectro de métodos e técnicas, adaptados ao caso específico em estudo. Conforme já referenciado, são características da pesquisa qualitativa a flexibilidade e a adaptabilidade, considerando que para cada problema objeto de pesquisa são necessários instrumentos e procedimentos específicos. A Figura 10 mostra os procedimentos da pesquisa qualitativa, evidenciando os métodos de campo mais utilizados: gruposfoco e entrevistas em profundidade:

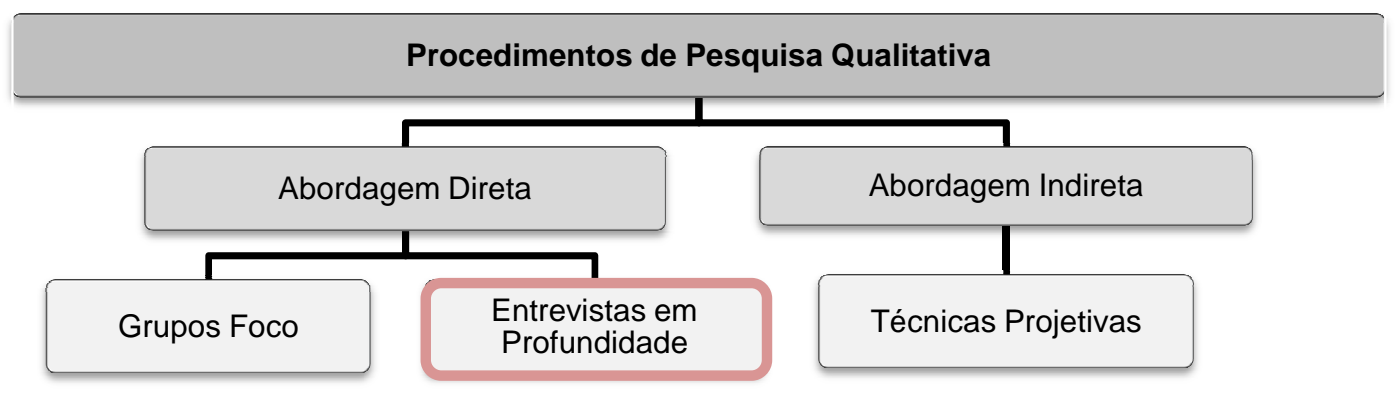

Figura 10: Procedimentos da pesquisa qualitativa

Fonte: Adaptado de Malhotra (2006, p. 156).

De acordo com Hair (2005, p. 152).

O tipo e a quantidade de dados a serem coletados dependem da natureza do estudo e dos objetivos da pesquisa. Se o estudo é exploratório, é provável que o pesquisador colete dados narrativos através do uso de grupos focus, entrevistas pessoais ou observação de comportamentos ou eventos.

A pesquisa de campo, em congruência com os objetivos deste estudo, caracteriza-se como exploratória, operacionalizada por meio de entrevistas em profundidade, com duas principais vertentes especialistas na questão-problema:

a) Chefs e proprietários de restaurantes na cidade de São Paulo; e

b) Profissionais da mídia especializada. 


\section{A.2 Definição do público a ser entrevistado}

Os objetivos da pesquisa definem a população-alvo a ser estudada. Como definição, população-alvo é entendida como o grupo completo de objetos ou elementos relevantes para o projeto de pesquisa, sendo que a relevância é dada à medida que se possuem informações que o projeto de pesquisa propõe-se a levantar (HAIR JR. et al., 2005, p. 239).

Conforme já referenciado, dois públicos foram delimitados para a abordagem exploratória deste estudo, por serem entendidos como especialistas e formadores de opinião no assunto "gastronomia na cidade de São Paulo". A seguir, apresenta-se a metodologia utilizada para selecionar o público entrevistado em cada uma das duas vertentes.

\section{A.2.1 Público I: proprietários ou chefs de restaurantes}

As entrevistas com proprietários e chefs de restaurantes considerados referência na cidade de São Paulo buscaram expressar a voz de quem está à frente de restaurantes destacados como referência na cidade. A seleção dos restaurantes seguiu a metodologia descrita a seguir (etapas representadas na Figura 11).

Foram considerados "referência" os restaurantes destacados pela mídia impressa como os melhores da cidade de São Paulo em edições específicas sobre o tema. Para selecionar tais restaurantes, partiu-se dos veículos de mídia impressa especializados que, nos anos de 2009 e 2010, destacaram os melhores restaurantes de São Paulo por meio (i) de atribuição de estrelas ou (ii) de votação de júri. A partir destes critérios, chegou-se a seis veículos:

- Guia Quatro Rodas Brasil;

- Guia Josimar;

- Guia da Folha - O Melhor de São Paulo;

- Revista Go Where Gastronomia - Os Melhores de São Paulo;

- Revista Época São Paulo - O Melhor de São Paulo;

- Revista Veja São Paulo - Comer \& Beber.

A partir dessas publicações, selecionaram-se os restaurantes citados como referência em pelos menos dois dos seis veículos, visando dirimir eventual 
parcialidade derivada da exibição em um único veículo. Desta forma, chegou-se a 104 restaurantes.

Em seguida, os restaurantes foram alocados nas categorias de cozinha que representam. Partiu-se da classificação utilizada pelas publicações analisadas; no entanto, como os veículos utilizam distinto espectro de categorias e nem sempre convergem na alocação de determinado restaurante em uma categoria, neste estudo seguiram-se hierarquicamente os critérios: (i) categoria na qual o restaurante é classificado em todas as edições analisadas (ii) categoria na qual o restaurante é classificado na maioria das edições analisadas; (iii) categoria na qual o restaurante foi considerado referência (estrela ou votação) o maior número de vezes.

Assim, os 104 restaurantes foram alocados em 19 categorias $^{24}$, conforme demonstrado na Tabela 19, que relaciona tais categorias e expressa a quantidade de restaurantes representantes de cada uma delas.

Tabela 19 - Categorias e quantidade de restaurantes com referência em mais de um veículo

\begin{tabular}{|cl|c|}
\hline \multicolumn{1}{|c|}{ Categorias } & $\begin{array}{c}\text { Quantidade de Restaurantes } \\
\text { com referência em mais de um dos seis veículos } \\
\text { de comunicação }\end{array}$ \\
\hline 1 & Italiana & 20 \\
2 & Francesa & 13 \\
3 & Carnes & 12 \\
4 & Variada & 12 \\
5 & Japonesa & 8 \\
6 & Pizzaria & 8 \\
7 & Contemporânea & 7 \\
8 & Brasileira & 4 \\
9 & Árabe & 3 \\
10 & Espanhola & 3 \\
11 & Peixes e Frutos do Mar & 3 \\
12 & Portuguesa & 3 \\
13 & Alemã & 1 \\
14 & Grega & 1 \\
15 & Judaica & 1 \\
16 & Peruana & 1 \\
17 & Suiça & 1 \\
18 & Tailandesa & 1 \\
19 & Vegetariana & 1 \\
\hline
\end{tabular}

Fonte: Elaborado pela autora (Guia Quatro Rodas Brasil; Guia Josimar; Guia da Folha - O Melhor de São Paulo; Revista Go Where Gastronomia - Os Melhores de São Paulo; Época O Melhor de São Paulo - Revista Época São Paulo; Comer \& Beber - Revista Veja São Paulo. Edições 2009 e 2010).

${ }^{24}$ Para este estudo, foram consideradas as categorias de restaurantes que representam e delimitam comidas e cozinhas. Não foram consideradas categorias associadas ao ambiente, localização, tipo de serviço ou horários de funcionamento dos estabelecimentos. 
Visando expressar nas entrevistas as cozinhas de maior destaque na cidade de São Paulo na atualidade, consideraram-se as categorias que exibem quantidade de referência superior a 1 . Desta forma, o universo passou a 96 restaurantes, alocados em 12 categorias.

Para eleição dos restaurantes cujos proprietários ou chefs seriam entrevistados, buscaram-se os estabelecimentos com maior número de referências em cada categoria, considerando as doze edições avaliadas, ou seja, aquelas de 2009 e 2010 dos veículos citados anteriormente. Foram selecionados como alvo para as entrevistas os três ${ }^{25}$ restaurantes de maior destaque em suas categorias. A partir daí, buscando ampliar a visão de cada categoria, foram realizadas duas entrevistas entre os três restaurantes selecionados ${ }^{26}$, chegando-se assim a 24 restaurantes com um representante entrevistado.

\begin{tabular}{|c|c|}
\hline $\begin{array}{l}\text { Selecionadas as publicaçóes de midia impressa } \\
\text { especializadas em gastronomia que anualmente elegem e } \\
\text { classificam "os melhores restaurantes da cidade de Săo } \\
\text { Paulo" - Ediçóes de } 2009 \text { e } 2010\end{array}$ & $\begin{array}{l}6 \text { Veiculos: } \\
\text { - Guia Quatro Rodas Brasil } \\
\text { - Guia Josimar } \\
\text { - Guia da Folha - O Melhor de Sáo Paulo } \\
\text { - Revista Go Where Gatronomia - Os Melhores de Săo Paulo } \\
\text { - Revista Veja Săo Paulo - Comer \& Beber } \\
\text { - Revista Epoca - O Melhor de Såo Paulo }\end{array}$ \\
\hline $\begin{array}{l}\text { Selecionados os restaurantes referenciados (estrela ou } \\
\text { votaçáo) em pelo menos duas das seis publicaçóes } \\
\text { avaliadas. }\end{array}$ & 104 restaurantes \\
\hline Alocaçáo dos Restaurantes em categorias & $\begin{array}{l}104 \text { restaurantes em } \\
19 \text { categorlas }\end{array}$ \\
\hline $\begin{array}{l}\text { Selecionadas as categorias com mais de um restaurante } \\
\text { alocado. }\end{array}$ & $\begin{array}{l}96 \text { restauranets em } \\
12 \text { categorias }\end{array}$ \\
\hline $\begin{array}{l}\text { Alocaçáo dos três restaurantes com maior número de } \\
\text { referências em cada uma das categorias, considerando as } \\
\text { doze ediçбes avaliadas, }\end{array}$ & $\begin{array}{l}38 \text { restaurantes } \theta \mathrm{m} \\
12 \text { categorias }\end{array}$ \\
\hline $\begin{array}{l}\text { Entrevistados os chefs ou prioprietários de dois dos trés } \\
\text { restaurantes com maior número de referências em cada } \\
\text { uma das categorias }\end{array}$ & $\begin{array}{l}24 \text { restaurantes em } \\
12 \text { categorias }\end{array}$ \\
\hline
\end{tabular}

Figura 11: Seleção do público restaurantes

Fonte: Elaborada pela autora.

${ }^{25} \mathrm{Em}$ duas categorias houve empate na quantidade de referências, fazendo com que se chegasse a 38 restaurantes.

${ }^{26}$ Na categoria Peixes \& Frutos do Mar, o restaurante Amadeus não foi considerado nas entrevistas em função do envolvimento direto da autora da presente pesquisa com este estabelecimento. 
O Quadro 4 relaciona os 24 restaurantes cujos chefs ou proprietários foram entrevistados, destacando suas categorias e o nome do entrevistado.

Todos os chefs e proprietários de restaurantes entrevistados foram questionados e consentiram em ter seus nomes e opiniões individualmente identificados no presente trabalho. Assim, na apresentação dos resultados da pesquisa de campo, no capítulo 5 , eles são referenciados pelos seus respectivos sobrenomes.

\begin{tabular}{|c|c|c|}
\hline Categoria & Restaurante & Entrevistado \\
\hline Árabe & Árabia & Sérgio Kuczynski \\
\hline Árabe & Tenda do Nilo & Olinda Pister \\
\hline Brasileira & Brasil a Gosto & Ana Luiza Trajano \\
\hline Brasileira & Dalva e Dito & Milad Alexandre Mack Atala \\
\hline Carnes & Baby Beef Rubaiyat (Grupo Rubaiyat) & Belarmino Iglesias Filho \\
\hline Carnes & Varanda Grill & Silvio Lazzarini Neto \\
\hline Contemporânea & D.O.M. & Milad Alexandre Mack Atala \\
\hline Contemporânea & Maní & Helena Rizzo \\
\hline Espanhola & Don Curro & José Maria Rios \\
\hline Espanhola & Eñe & Flávio Miyamura \\
\hline Francesa & La Brasserie Erick Jacquin & Erick Jacquin \\
\hline Francesa & La Casserole & Marie-France Henry \\
\hline Italiana & Due Cuochi Cucina & Paulo Barroso de Barros \\
\hline Italiana & Fasano (Grupo Fasano) & Fabrizio Fasano \\
\hline Japonesa & Jun Sakamoto & Jun Sakamoto \\
\hline Japonesa & Kinoshita & Tsuyoshi Murakami \\
\hline Peixes e Frutos do Mar & Porto Rubayat (Grupo Rubaiyat) & Belarmino Iglesias Filho \\
\hline Peixes e Frutos do Mar & Rufino's & Rufino Casal Treinta \\
\hline Pizzaria & Bráz & Edgar Bueno da Costa \\
\hline Pizzaria & I Vitelloni & Hamilton Mellão Junior \\
\hline Portuguesa & A Bela Sintra & Carlos Bettencourt \\
\hline Portuguesa & Antiquarius & Thales Martins Filho \\
\hline Variada & A Figueira Rubaiyat (Grupo Rubaiyat) & Belarmino Iglesias Filho \\
\hline Variada & Arturito & Paola Carossela \\
\hline
\end{tabular}

\section{Quadro 4: Público entrevistado: restaurantes}

Fonte: Elaborado pela autora (Guia Quatro Rodas Brasil; Guia Josimar; Guia da Folha - O Melhor de São Paulo; Revista Go Where Gastronomia - Os Melhores de São Paulo; Época O Melhor de São Paulo - Revista Época São Paulo; Comer \& Beber - Revista Veja São Paulo. Edições 2009 e 2010. Entrevistas realizadas com chefs e proprietários dos restaurantes. 


\section{A.2.2 Público II - Profissionais da mídia especializada}

A magnitude da oferta gastronômica da cidade de São Paulo garante cada vez mais espaço à mídia especializada no assunto na cidade de São Paulo. Para expressar a voz de quem atua como jornalista gastronômico, foram entrevistados os seis principais profissionais em atuação no cenário nacional.

O Quadro 5 relaciona tais profissionais, destacando os veículos de mídia impressa no qual atuam nos dias de hoje.

Todos os profissionais da mídia especializada entrevistados foram questionados e consentiram em ter seus nomes e opiniões individualmente identificados no presente trabalho. Assim, na apresentação dos resultados da pesquisa de campo, no capítulo 5 , eles são referenciados pelos seus respectivos sobrenomes.

\begin{tabular}{|l|l|}
\hline \multicolumn{1}{|c|}{ Veículo de Comunicação } & \multicolumn{1}{c|}{ Entrevistado } \\
\hline Guia Quatro Rodas Brasil - Editora Abril & Ricardo Castanho \\
\hline Guia Josimar - Editora DBA; Jornal Folha de São Paulo & Josimar Melo \\
\hline Jornal O Estado de São de Paulo & Luiz Américo Camargo \\
\hline Revista Gosto - Editora Isabella; Jornal O Estado de São Paulo & J.A. Dias Lopes \\
\hline Revista Prazeres da Mesa - Editora 4 Capas & Ricardo Castilho \\
\hline Revista Veja São Paulo - Editora Abril & Arnaldo Lorençato \\
\hline
\end{tabular}

Quadro 5: Público entrevistado: profissionais da mídia especializada

Fonte: Elaborado pela autora. Entrevistas com profissionais da mídia especializada.

\section{A.3 Roteiro e Execução das Entrevistas}

Todas as entrevistas realizadas neste trabalho foram conduzidas pessoalmente pela autora no local de preferência do entrevistado, entre Setembro/2010 e Janeiro/2011.

Foi utilizado um roteiro de entrevista semi-estruturado que contou com quatro adaptações, buscando capturar especificidades associadas aos entrevistados - (i) profissionais da mídia especializada, (ii) restaurantes de cozinha brasileira, (iii) 
restaurantes "étnicos" e (iv) outros restaurantes ${ }^{27}$. Foi desenvolvido buscando mapear quatro macro-assuntos:

- Mudanças ocorridas no mercado de alimentação e, mais especificamente, de restaurantes na cidade de São Paulo;

- Caracterização da oferta gastronômica da cidade de São Paulo;

- São Paulo em relação à gastronomia brasileira;

- O local e o global na gastronomia paulistana.

Com a anuência de todos os entrevistados, as entrevistas foram gravadas em áudio tendo sido posteriormente transcritas.

A seguir, apresentam-se os roteiros utilizados nas entrevistas:

\section{A.3.1 Roteiro Chefs e Proprietários de Restaurantes}

\section{Apresentação}

- Nome completo;

- Nacionalidade e ascendência;

- Tempo que está no Brasil;

- Idade do restaurante;

- Tempo que atua no ramo;

- Tempo que atua no restaurante;

- Questionamento quanto ao consentimento para gravar a entrevista;

- Questionamento quanto à exposição do nome real na apresentação do trabalho.

\section{Roteiro}

- Como você caracteriza a oferta gastronômica na cidade de São Paulo? - Apenas para os restaurantes "étnicos": Quais são para você as principais diferenças entre um restaurante \{nacionalidade\} na \{local de origem\} e um restaurante \{nacionalidade\} em São Paulo?

- Quão \{nacionalidade\} e quão brasileiro você considera seu restaurante? Por que? Isso mudou no decorrer dos anos?

27 "Outros restaurantes" compreende as categorias "carnes", "peixes e frutos do mar" e "variados". 
- Você diria que há uma correspondência real com a oferta de lá ou se aproximam mais de um estereótipo construído aqui? Exite uma preocupação em acompanhar as tendências em curso na \{local de origem\}?

- Apenas para os restaurantes variados: Quão brasileiro e quão internacional você considera seu restaurante? Por que? Isso mudou no decorrer dos anos?

- O restaurante é de \{\} . Ao longo desses \{\} anos, quais as principais mudanças que você observou no que se refere ao acesso a produtos e ingredientes?

- E no que diz respeito ao restaurante em si?

- E ainda no que concerne aos hábitos de consumo e público frequentador?

- E na concorrência?

- E em relação à mídia?

- Quais os meios que você utiliza para abastecer o seu restaurante?

- Que tipo de produtos você compra de cada um deles? Isso tem mudado? Por que?

- Como você definiria a comida brasileira?

- O hábito alimentar do paulistano Ihe parece estar refletido nessa noção de comida brasileira?

- Acarajé e cocada, por exemplo, são preparações reconhecidamente brasileiras. E o que você diria de itens como bife à parmegiana, também são?

- O que os diferencia? Poderiam igualmente fazer parte dos cardápios dos restaurantes de cozinha brasileira?

- Recentemente tem-se ouvido muito falar sobre "valorização da gastronomia brasileira". O que você entende por "valorização da gastronomia brasileira"?

- De que forma você considera estar envolvido nesse processo?

- Como São Paulo insere-se nesse movimento de valorização da gastronomia brasileira?

- Alguns autores dizem que a Globalização está causando a homogeneização do mundo (caracterizada por alguns como estandartização do gosto). Como você enxerga esta questão? 
- Para você, de que maneira o local e o global dialogam na oferta gastronômica paulistana?

- Qual seu entendimento de local?

- Posso dizer que em São Paulo a noção do que é local é alargada, passando a representar o nacional?

- Neste contexto, São Paulo pode ser entendida como um espécie de vitrine do Brasil? Ou mais que isso, como ponto de conexão entre o local e o global, na medida em que pode representar o Brasil para aqueles que vêm de fora e o mundo para os brasileiros?

\section{A.3.2 Roteiro Profissionais da Mídia Especializada}

\section{Apresentação}

- Nome completo;

- Tempo que atua na área;

- Veículos nos quais atua;

- Questionamento quanto ao consentimento para gravar a entrevista;

- Questionamento quanto à exposição do nome real na apresentação do trabalho.

\section{Roteiro}

- Como você caracteriza a oferta gastronômica na cidade de São Paulo?

- Nos dos restaurantes étnicos, de 0 a 10, quão fiéis à sua origem e quão abrasileirados você diria que eles são?

- Isso mudou no decorrer dos anos?

- Há para você uma correspondência com a oferta de lá ou se aproximam mais de um estereótipo construído aqui?

- Você atua como jornalista há \{\} anos. Ao longo deste tempo, quais as principais mudanças que você observou no que se refere à composição da oferta da cidade de São Paulo?

- E no que diz respeito a produtos e ingredientes utilizados?

- E, ainda, no que concerne aos hábitos de consumo e público consumidor? 
- E em relação à atuação da mídia especializada?

- Como você definiria comida brasileira?

- O hábito alimentar do paulistano Ihe parece estar refletido nessa noção de comida brasileira?

- Acarajé e cocada, por exemplo, são preparações reconhecidamente brasileiras. E o que você diria de itens como bife à parmegiana, também são?

- O que os diferencia? Poderiam igualmente fazer parte dos cardápios dos restaurantes de cozinha brasileira?

- Tem-se falado muito em "valorização da gastronomia brasileira". O que você entende por "valorização da gastronomia brasileira"?

- De que forma você considera estar envolvido nesse processo?

- Como São Paulo insere-se nesse movimento de "valorização da gastronomia brasileira"?

- Alguns autores dizem que a Globalização está causando a homogeneização do mundo, pontuada por alguns como estandartização do gosto. Como você enxerga esta questão?

- Para você, de que maneira o local e o global dialogam na oferta gastronômica paulistana?

- Qual seu entendimento de local?

- Posso dizer que em São Paulo a noção do que é local é alargada, passando a representar o nacional?

- Neste contexto, São Paulo pode ser entendida como uma espécie de vitrine do Brasil? Ou mais que isso, como ponto de conexão entre o local e o global, na medida em que pode representar o Brasil para aqueles que vêm de fora e o mundo para os brasileiros? 
ANEXO A

Tabela 20: Aquisição alimentar domiciliar anual em São Paulo(ENDEF 1974/1975 - POF 2008/2009)

\begin{tabular}{|c|c|c|c|}
\hline Produtos (Kg per capita/ano) & $\begin{array}{c}\text { POF } \\
\text { 2008/2009 } \\
\text { (Município de São Paulo) }\end{array}$ & \begin{tabular}{|c|} 
ENDEF \\
$1974 / 1975$ \\
(Região Metropolitana SP)
\end{tabular} & POF/ ENDEF \\
\hline Cereais e leguminosas & 24,5 & 66,1 & 0,37 \\
\hline Cereais & 19,2 & 46,7 & 0,41 \\
\hline Arroz não especificado & 8,0 & 45,6 & 0,17 \\
\hline Arroz polido & 10,7 & 0,0 & - \\
\hline Milho em grão & 0,3 & 0,2 & 1,44 \\
\hline Milho verde em conserva & 0,2 & 0,0 & - \\
\hline Milho verde em espiga & 0,0 & 0,5 & 0,04 \\
\hline Outros & 0,0 & 0,4 & 0,10 \\
\hline Leguminosas & 5,3 & 19,4 & 0,27 \\
\hline Feijão-fradinho & 0,1 & 0,0 & - \\
\hline Feijão-jalo & 0,1 & 0,0 & - \\
\hline Feijão-manteiga & 0,2 & 0,0 & - \\
\hline Feijão-mulatinho & 1,0 & 2,8 & 0,34 \\
\hline Feijão-preto & 0,4 & 0,5 & 0,84 \\
\hline Feijão-rajado & 3,1 & 0,0 & - \\
\hline Feijão-roxo & 0,0 & 10,4 & 0,00 \\
\hline Outros feijões & & 4,8 & - \\
\hline Outras & 0,3 & 0,9 & 0,38 \\
\hline Hortaliças & 26,7 & 60,9 & 0,44 \\
\hline Hortaliças folhosas e florais & 3,5 & 11,9 & 0,29 \\
\hline Acelga & 0,1 & 0,0 & - \\
\hline Agrião & 0,1 & 0,0 & - \\
\hline Alface & 1,3 & 3,1 & 0,42 \\
\hline Cheiro-verde & 0,1 & 0,9 & 0,10 \\
\hline Couve & 0,3 & 1,2 & 0,28 \\
\hline Couve-brócolis & 0,4 & 0,0 & - \\
\hline Couve-flor & 0,2 & 0,8 & 0,25 \\
\hline Repolho & 0,6 & 2,0 & 0,28 \\
\hline Outras & 0,4 & 3,9 & 0,11 \\
\hline Hortaliças frutosas & 12,7 & 27,0 & 0,47 \\
\hline Abóbora & 0,5 & 1,0 & 0,52 \\
\hline Abobrinha & 0,9 & 1,7 & 0,55 \\
\hline Azeitona em conserva & 0,3 & 0,0 & - \\
\hline Berinjela & 0,4 & 0,0 & - \\
\hline Cebola & 2,8 & 5,6 & 0,50 \\
\hline Chuchu & 0,7 & 2,8 & 0,26 \\
\hline Jiló & 0,1 & 0,4 & 0,35 \\
\hline Maxixe & 0,0 & 0,0 & - \\
\hline Pepino fresco & 0,7 & 1,3 & 0,52 \\
\hline Pimentão & 0,6 & 0,9 & 0,69 \\
\hline Quiabo & 0,1 & 0,3 & 0,26 \\
\hline Tomate & 5,1 & 9,6 & 0,54 \\
\hline Vagem & 0,2 & 1,2 & 0,20 \\
\hline Outras & 0,1 & 2,2 & 0,07 \\
\hline Hortaliças tuberosas e outras & 10,6 & 22,0 & 0,48 \\
\hline Alho & 0,5 & 0,6 & 0,75 \\
\hline Batata-aipo & 0,4 & 0,0 & - \\
\hline Batata-baroa & 0,0 & 0,0 & - \\
\hline Batata-doce & 0,2 & 0,6 & 0,25 \\
\hline Batata-inglesa & 3,4 & 16,6 & 0,20 \\
\hline Batata não especificada & 2,9 & 0,0 & - \\
\hline Beterraba & 0,5 & 0,6 & 0,75 \\
\hline Cará & 0,0 & 0,0 & - \\
\hline Cenoura & 1,9 & 1,4 & 1,34 \\
\hline Inhame & 0,1 & 0,8 & 0,18 \\
\hline Mandioca & 0,6 & 1,3 & 0,49 \\
\hline Outras & 0,2 & 0,1 & 1,59 \\
\hline Frutas & 37,1 & 50,1 & 0,74 \\
\hline Frutas de clima tropical & 31,4 & 45,3 & 0,69 \\
\hline Abacate & 0,4 & 1,3 & 0,34 \\
\hline Abacaxi & 1,1 & 1,8 & 0,59 \\
\hline Acerola & - & 0,0 & - \\
\hline
\end{tabular}


Tabela 20 (cont.): Aquisição alimentar domiciliar anual em São Paulo (ENDEF 1974/1975 - POF 2008/2009)

\begin{tabular}{|c|c|c|c|}
\hline Produtos (Kg per capita/ano) & $\begin{array}{c}\text { POF } \\
\text { 2008/2009 } \\
\text { (Município de São Paulo) }\end{array}$ & $\begin{array}{c}\text { ENDEF } \\
1974 / 1975 \\
\text { (Região Metropolitana SP) }\end{array}$ & POF/ ENDEF \\
\hline Banana-d'água & 4,5 & \begin{tabular}{|c|}
7,7 \\
\end{tabular} & 0,59 \\
\hline Banana-da-terra & 0,0 & 0,1 & 0,11 \\
\hline Banana-maçã & 0,2 & 1,0 & 0,19 \\
\hline Banana-ouro & - & 0,0 & - \\
\hline Banana-prata & 2,4 & 0,4 & 5,93 \\
\hline Outras bananas & 1,9 & 0,1 & 18,59 \\
\hline Goiaba & 0,4 & 0,0 & - \\
\hline Laranja-baía & 0,0 & 1,5 & 0,01 \\
\hline Laranja-lima & 1,1 & 1,8 & 0,59 \\
\hline Laranja-pera & 5,7 & 16,7 & 0,34 \\
\hline Laranja-seleta & - & 0,9 & - \\
\hline Outras laranjas & 2,0 & 0,1 & 20,20 \\
\hline Limão comum & 1,2 & 1,5 & 0,83 \\
\hline Mamão & 3,2 & 2,0 & 1,60 \\
\hline Manga & 1,2 & 0,6 & 1,99 \\
\hline Maracujá & 0,2 & 0,0 & - \\
\hline Melancia & 3,4 & 2,1 & 1,64 \\
\hline Melão & 0,6 & 0,0 & - \\
\hline Tangerina & 1,7 & 5,3 & 0,33 \\
\hline Outras & 0,2 & 0,4 & 0,51 \\
\hline Frutas de clima temperado & 5,6 & 4,8 & 1,17 \\
\hline Ameixa & 0,2 & 0,0 & - \\
\hline Caqui & 0,4 & 0,0 & - \\
\hline Maçã & 2,4 & 1,9 & 1,26 \\
\hline Morango & 0,3 & 0,0 & - \\
\hline Pera & 0,8 & 0,0 & - \\
\hline Pêssego & 0,5 & 0,0 & - \\
\hline Uva & 0,9 & 0,0 & - \\
\hline Outras & 0,2 & 2,9 & 0,07 \\
\hline Cocos, castanhas e nozes & 0,3 & 0,5 & 0,53 \\
\hline Cocos & 0,2 & 0,2 & 1,12 \\
\hline Açaí (emulsão) & 0,1 & 0,0 & - \\
\hline Coco-da-baía & 0,0 & 0,0 & - \\
\hline Outros & 0,1 & 0,2 & 0,36 \\
\hline Castanhas e nozes & 0,0 & 0,3 & 0,14 \\
\hline Farinhas, féculas e massas & 7,9 & 11,1 & 0,71 \\
\hline Farinhas & 2,3 & 3,1 & 0,74 \\
\hline Farinha de mandioca & 0,5 & 1,0 & 0,52 \\
\hline Farinha de rosca & 0,1 & 0,0 & - \\
\hline Farinha de trigo & 1,6 & 2,1 & 0,76 \\
\hline Farinha vitaminada & 0,0 & 0,0 & - \\
\hline Outras & 0,0 & 0,0 & - \\
\hline Féculas & 1,2 & 1,6 & 0,73 \\
\hline Amido de milho & 0,1 & 0,0 & - \\
\hline Creme de arroz & 0,0 & 0,0 & - \\
\hline Creme de milho & 0,0 & 0,0 & - \\
\hline Fécula de mandioca & 0,1 & 0,1 & 0,90 \\
\hline Flocos de aveia & 0,0 & 0,0 & - \\
\hline Flocos de milho & 0,6 & 0,0 & - \\
\hline Flocos de outros cereais & 0,0 & 0,0 & - \\
\hline Fubá de milho & 0,3 & 1,1 & 0,27 \\
\hline Outras & 0,0 & 0,4 & 0,02 \\
\hline Massas & 4,4 & 6,4 & 0,69 \\
\hline Macarrão com ovos & 1,5 & 0,0 & - \\
\hline Macarrão não especificado & 2,4 & 6,4 & 0,37 \\
\hline Macarrão sem ovos & 0,0 & 0,0 & - \\
\hline Massa de lasanha & 0,1 & 0,0 & - \\
\hline Massa de pastel & 0,1 & 0,0 & - \\
\hline Massa de pizza & 0,2 & 0,0 & - \\
\hline Outras & 0,1 & 0,0 & - \\
\hline
\end{tabular}


Tabela 20 (cont.): Aquisição alimentar domiciliar anual em São Paulo (ENDEF 1974/1975 - POF 2008/2009)

\begin{tabular}{|c|c|c|c|}
\hline Produtos (Kg per capita/ano) & $\begin{array}{c}\text { POF } \\
\text { 2008/2009 } \\
\text { (Município de São Paulo) }\end{array}$ & \begin{tabular}{|c|} 
ENDEF \\
$1974 / 1975$ \\
(Região Metropolitana SP)
\end{tabular} & POF/ ENDEF \\
\hline Banana-d'água & 4,5 & 7,7 & 0,59 \\
\hline Banana-da-terra & 0,0 & 0,1 & 0,11 \\
\hline Banana-maçã & 0,2 & 1,0 & 0,19 \\
\hline Banana-ouro & - & 0,0 & - \\
\hline Banana-prata & 2,4 & 0,4 & 5,93 \\
\hline Outras bananas & 1,9 & 0,1 & 18,59 \\
\hline Goiaba & 0,4 & 0,0 & - \\
\hline Laranja-baía & 0,0 & 1,5 & 0,01 \\
\hline Laranja-lima & 1,1 & 1,8 & 0,59 \\
\hline Laranja-pera & 5,7 & 16,7 & 0,34 \\
\hline Laranja-seleta & - & 0,9 & - \\
\hline Outras Iaranjas & 2,0 & 0,1 & 20,20 \\
\hline Limão comum & 1,2 & 1,5 & 0,83 \\
\hline Mamão & 3,2 & 2,0 & 1,60 \\
\hline Manga & 1,2 & 0,6 & 1,99 \\
\hline Maracujá & 0,2 & 0,0 & - \\
\hline Melancia & 3,4 & 2,1 & 1,64 \\
\hline Melão & 0,6 & 0,0 & - \\
\hline Tangerina & 1,7 & 5,3 & 0,33 \\
\hline Outras & 0,2 & 0,4 & 0,51 \\
\hline Frutas de clima temperado & 5,6 & 4,8 & 1,17 \\
\hline Ameixa & 0,2 & 0,0 & - \\
\hline Caqui & 0,4 & 0,0 & - \\
\hline Maçã & 2,4 & 1,9 & 1,26 \\
\hline Morango & 0,3 & 0,0 & - \\
\hline Pera & 0,8 & 0,0 & - \\
\hline Pêssego & 0,5 & 0,0 & - \\
\hline Uva & 0,9 & 0,0 & - \\
\hline Outras & 0,2 & 2,9 & 0,07 \\
\hline Cocos, castanhas e nozes & 0,3 & 0,5 & 0,53 \\
\hline Cocos & 0,2 & 0,2 & 1,12 \\
\hline Açaí (emulsão) & 0,1 & 0,0 & - \\
\hline Coco-da-baía & 0,0 & 0,0 & - \\
\hline Outros & 0,1 & 0,2 & 0,36 \\
\hline Castanhas e nozes & 0,0 & 0,3 & 0,14 \\
\hline Farinhas, féculas e massas & 7,9 & 11,1 & 0,71 \\
\hline Farinhas & 2,3 & 3,1 & 0,74 \\
\hline Farinha de mandioca & 0,5 & 1,0 & 0,52 \\
\hline Farinha de rosca & 0,1 & 0,0 & - \\
\hline Farinha de trigo & 1,6 & 2,1 & 0,76 \\
\hline Farinha vitaminada & 0,0 & 0,0 & - \\
\hline Outras & 0,0 & 0,0 & - \\
\hline Féculas & 1,2 & 1,6 & 0,73 \\
\hline Amido de milho & 0,1 & 0,0 & - \\
\hline Creme de arroz & 0,0 & 0,0 & - \\
\hline Creme de milho & 0,0 & 0,0 & - \\
\hline Fécula de mandioca & 0,1 & 0,1 & 0,90 \\
\hline Flocos de aveia & 0,0 & 0,0 & - \\
\hline Flocos de milho & 0,6 & 0,0 & - \\
\hline Flocos de outros cereais & 0,0 & 0,0 & - \\
\hline Fubá de milho & 0,3 & 1,1 & 0,27 \\
\hline Outras & 0,0 & 0,4 & 0,02 \\
\hline Massas & 4,4 & 6,4 & 0,69 \\
\hline Macarrão com ovos & 1,5 & 0,0 & - \\
\hline Macarrão não especificado & 2,4 & 6,4 & 0,37 \\
\hline Macarrão sem ovos & 0,0 & 0,0 & - \\
\hline Massa de lasanha & 0,1 & 0,0 & - \\
\hline Massa de pastel & 0,1 & 0,0 & - \\
\hline Massa de pizza & 0,2 & 0,0 & - \\
\hline Outras & 0,1 & 0,0 & - \\
\hline
\end{tabular}


Tabela 20 (cont.): Alimentar domiciliar anual em São Paulo (ENDEF 1974/1975 - POF 2008/2009)

\begin{tabular}{|c|c|c|c|}
\hline Produtos (Kg per capita/ano) & $\begin{array}{c}\text { POF } \\
\text { 2008/2009 } \\
\text { (Município de São Paulo) }\end{array}$ & $\begin{array}{c}\text { ENDEF } \\
1974 / 1975 \\
\text { (Região Metropolitana SP) }\end{array}$ & POF/ ENDEF \\
\hline Panificados & 26,7 & 28,5 & 0,94 \\
\hline Pães & 21,4 & 25,2 & 0,85 \\
\hline Pão caseiro & 0,0 & 0,0 & - \\
\hline Pão de forma de padaria & 0,0 & 0,0 & - \\
\hline Pão de forma industrializado & 1,7 & 0,0 & - \\
\hline Pão de milho & 0,1 & 0,0 & - \\
\hline Pão de queijo & 0,2 & 0,0 & - \\
\hline Pão doce & 2,0 & 0,0 & - \\
\hline Pão francês & 16,6 & 23,6 & 0,70 \\
\hline Pão integral & 0,3 & 0,0 & - \\
\hline Torrada & 0,1 & 0,0 & - \\
\hline Outros & 0,5 & 1,6 & 0,28 \\
\hline Bolos & 1,0 & 2,0 & 0,49 \\
\hline Biscoitos, roscas, etc. & 4,3 & 1,3 & 3,29 \\
\hline Biscoito doce & 2,6 & 0,0 & - \\
\hline Biscoito não especificado & 0,1 & 1,3 & 0,07 \\
\hline Biscoito salgado & 1,5 & 0,0 & - \\
\hline Rosca doce & 0,0 & 0,0 & - \\
\hline Rosca não especificada & 0,0 & 0,0 & - \\
\hline Rosca salgada & - & 0,0 & - \\
\hline Outros & 0,0 & 0,0 & - \\
\hline Carnes & 21,0 & 25,8 & 0,82 \\
\hline Carnes bovinas de primeira & 6,6 & 17,6 & 0,38 \\
\hline Alcatra & 1,0 & 0,0 & - \\
\hline Carne moída & 0,5 & 0,0 & - \\
\hline Carne não especificada & 1,5 & 0,0 & - \\
\hline Chã de dentro & 1,6 & 0,0 & - \\
\hline Contrafilé & 0,6 & 0,0 & - \\
\hline Filé-mignon & 0,2 & 0,0 & - \\
\hline Lagarto comum & 0,6 & 0,0 & - \\
\hline Lagarto redondo & - & 0,0 & - \\
\hline Patinho & 0,6 & 17,6 & 0,04 \\
\hline Carnes bovinas de segunda & 5,9 & 1,0 & 5,88 \\
\hline Acém & 2,4 & 0,0 & - \\
\hline Capa de filé & 0,2 & 0,0 & - \\
\hline Carne moída & 0,7 & 0,0 & - \\
\hline Carne não especificada & 0,3 & 0,0 & - \\
\hline Costela & 1,2 & 0,0 & - \\
\hline Músculo & 0,5 & 0,0 & - \\
\hline Pá & 0,2 & 0,0 & - \\
\hline Peito & 0,1 & 0,0 & - \\
\hline Outras & 0,3 & 1,0 & 0,27 \\
\hline Carnes bovinas outras & 1,8 & 0,9 & 2,00 \\
\hline Carne de hambúrguer & 0,3 & 0,0 & - \\
\hline Carne de sol & - & 0,0 & - \\
\hline Carne moída não especificada & 0,2 & 0,0 & - \\
\hline Carne não especificada & 0,6 & 0,0 & - \\
\hline Carne-seca & 0,1 & 0,4 & 0,22 \\
\hline Mocotó & 0,0 & 0,0 & - \\
\hline Outras & 0,6 & 0,5 & 1,10 \\
\hline Carnes suínas com osso e sem osso & 1,3 & 2,1 & 0,64 \\
\hline Carré & 0,6 & 0,0 & - \\
\hline Costela & 0,4 & 0,0 & - \\
\hline Lombo & 0,0 & 0,0 & - \\
\hline Pernil & 0,2 & 0,0 & - \\
\hline Porco eviscerado & - & 0,0 & - \\
\hline Outras & 0,1 & 2,1 & 0,06 \\
\hline Carnes suínas outras & 3,3 & 3,8 & 0,87 \\
\hline Carne salgada não especificada & 0,0 & 0,0 & - \\
\hline Costela de porco salgada & 0,1 & 0,0 & - \\
\hline Mortadela & 0,6 & 0,0 & - \\
\hline Paio & 0,0 & 0,0 & - \\
\hline
\end{tabular}


Tabela 20 (cont.): Evolução na aquisição alimentar domiciliar anual em São Paulo (ENDEF 1974/1975 - POF 2008/2009)

\begin{tabular}{|c|c|c|c|}
\hline Produtos (Kg per capita/ano) & $\begin{array}{c}\text { POF } \\
\text { 2008/2009 } \\
\text { (Município de São Paulo) }\end{array}$ & $\begin{array}{c}\text { ENDEF } \\
1974 / 1975 \\
\text { (Região Metropolitana SP) }\end{array}$ & POF/ ENDEF \\
\hline Pé de porco salgado & 0,0 & 0,0 & - \\
\hline Presunto & 0,6 & 0,0 & - \\
\hline Salame & 0,1 & 0,0 & - \\
\hline Salsicha comum & 1,6 & 3,0 & 0,55 \\
\hline Toucinho fresco & - & 0,8 & - \\
\hline Toucinho defumado & 0,1 & 0,0 & - \\
\hline Outras & 0,0 & 0,0 & - \\
\hline Carnes de outros animais & 2,1 & 0,4 & 5,20 \\
\hline Carne de cabrito & - & 0,0 & - \\
\hline Carne de carneiro & - & 0,1 & - \\
\hline Linguiça & 2,0 & 0,0 & - \\
\hline Outras & 0,1 & 0,3 & 0,31 \\
\hline Vísceras & 0,3 & 1,3 & 0,25 \\
\hline Vísceras bovinas & 0,3 & 0,0 & - \\
\hline Bucho & - & 0,0 & - \\
\hline Fígado & 0,3 & 0,0 & - \\
\hline Língua & - & 0,0 & - \\
\hline Outras & 0,0 & 0,0 & - \\
\hline Vísceras suínas & - & 0,0 & - \\
\hline Outras vísceras & 0,0 & 0,0 & - \\
\hline Pescados & 2,0 & 4,8 & 0,41 \\
\hline Pescados de água salgada & 1,5 & 4,1 & 0,35 \\
\hline Anchova fresca & - & 0,0 & - \\
\hline Bacalhau & 0,2 & 0,0 & - \\
\hline Bagre fresco & - & 0,0 & - \\
\hline Cação fresco & 0,1 & 0,0 & - \\
\hline Camarão fresco & 0,0 & 0,2 & 0,22 \\
\hline Corvina fresca & 0,1 & 0,0 & - \\
\hline Merluza em filé congelado & 0,1 & 0,0 & - \\
\hline Merluza em filé fresco & - & 0,0 & - \\
\hline Parati fresco & - & 0,0 & - \\
\hline Pescada em filé congelado & 0,1 & 0,0 & - \\
\hline Pescada em filé fresco & 0,1 & 0,0 & - \\
\hline Pescada fresca & 0,1 & 0,0 & - \\
\hline Pescadinha fresca & - & 0,0 & - \\
\hline Sardinha em conserva & 0,1 & 0,4 & 0,31 \\
\hline Sardinha fresca & 0,1 & 0,0 & - \\
\hline Tainha fresca & - & 0,0 & - \\
\hline Outros pescados em filé congelado & 0,2 & 0,0 & - \\
\hline Outros pescados em filé fresco & 0,2 & 0,0 & - \\
\hline Outros pescados frescos & 0,1 & 3,0 & 0,04 \\
\hline Outros pescados salgados & - & 0,5 & - \\
\hline Pescados de água doce & 0,2 & 0,7 & 0,25 \\
\hline Acará fresca & - & 0,0 & - \\
\hline Acari fresco & - & 0,0 & - \\
\hline Anujá fresco & - & 0,0 & - \\
\hline Curimatã fresco & 0,0 & 0,0 & - \\
\hline Dourada fresca & - & 0,0 & - \\
\hline Jaraqui fresco & - & 0,0 & - \\
\hline Lambari fresco & - & 0,0 & - \\
\hline Mapará fresco & - & 0,0 & - \\
\hline Piau fresco & - & 0,0 & - \\
\hline Surubim fresco & - & 0,0 & - \\
\hline Tambaqui fresco & - & 0,0 & - \\
\hline Tilápia fresca & - & 0,0 & - \\
\hline Traíra fresca & - & 0,0 & - \\
\hline Tucunaré fresco & - & 0,0 & - \\
\hline Outros pescados em filé congelado & - & 0,0 & - \\
\hline Outros pescados em filé fresco & 0,0 & 0,0 & - \\
\hline Outros pescados frescos & 0,1 & 0,7 & 0,19 \\
\hline Outros pescados salgados & - & 0,0 & - \\
\hline
\end{tabular}


Tabela 20 (cont.): Evolução na aquisição alimentar domiciliar anual em São Paulo (ENDEF 1974/1975 - POF 2008/2009)

\begin{tabular}{|c|c|c|c|}
\hline Produtos (Kg per capita/ano) & $\begin{array}{c}\text { POF } \\
\text { 2008/2009 } \\
\text { (Município de São Paulo) }\end{array}$ & \begin{tabular}{|c|} 
ENDEF \\
$1974 / 1975$ \\
(Região Metropolitana SP)
\end{tabular} & POF/ ENDEF \\
\hline Pescados não especificados & 0,3 & 0,0 & - \\
\hline Peixe em filé congelado & - & 0,0 & - \\
\hline Peixe em filé fresco & - & 0,0 & - \\
\hline Peixe fresco & 0,3 & 0,0 & - \\
\hline Peixe salgado & - & 0,0 & - \\
\hline Aves e ovos & 11,3 & 18,7 & 0,61 \\
\hline Aves & 8,8 & 11,0 & 0,80 \\
\hline Asa de frango & 0,4 & 0,0 & - \\
\hline Carne de frango não especificada & 0,6 & 0,0 & - \\
\hline Coxa de frango & 1,4 & 0,0 & - \\
\hline Dorso de frango & 0,0 & 0,0 & - \\
\hline Frango abatido (inteiro) & 3,9 & 0,0 & - \\
\hline Frango vivo & 0,0 & 0,0 & - \\
\hline Miúdos de frango & 0,1 & 0,0 & - \\
\hline Peito de frango & 1,8 & 0,0 & - \\
\hline Outras carnes de frango & 0,2 & 0,0 & - \\
\hline Pato inteiro ou em cortes & - & 0,0 & - \\
\hline Peru abatido & 0,1 & 0,0 & - \\
\hline Peru em cortes & 0,2 & 0,0 & - \\
\hline Outras & 0,0 & 0,0 & - \\
\hline Ovos & 2,5 & 7,7 & 0,33 \\
\hline Ovo de galinha & 2,5 & 0,0 & - \\
\hline Outros & 0,0 & 0,0 & - \\
\hline Laticínios & 48,8 & 60,4 & 0,81 \\
\hline Leite e creme de leite & 42,7 & 56,5 & 0,76 \\
\hline Creme de leite & 0,4 & 0,0 & - \\
\hline Leite condensado & 0,7 & 0,0 & - \\
\hline Leite de vaca fresco & - & 0,6 & - \\
\hline Leite de vaca pasteurizado & 39,2 & 53,8 & 0,73 \\
\hline Leite em pó desengordurado & 0,1 & 0,0 & - \\
\hline Leite em pó integral & 0,6 & 2,1 & 0,28 \\
\hline Leite em pó não especificado & 0,0 & 0,0 & - \\
\hline Outros & 1,7 & 0,0 & - \\
\hline Queijos e requeijão & 2,6 & 2,0 & 1,31 \\
\hline Queijo minas & 0,6 & 0,0 & - \\
\hline Queijo mozzarella & 1,1 & 0,0 & - \\
\hline Queijo não especificado & 0,1 & 0,0 & - \\
\hline Queijo parmezão & 0,2 & 0,0 & - \\
\hline Queijo prato & 0,2 & 0,0 & - \\
\hline Outros queijos & 0,1 & 2,0 & 0,06 \\
\hline Requeijão & 0,4 & 0,0 & - \\
\hline Outros laticínios & 3,5 & 1,9 & 1,85 \\
\hline logurte & 2,2 & 0,8 & 2,81 \\
\hline Leite fermentado & 0,9 & 0,0 & - \\
\hline Manteiga & 0,3 & 0,5 & 0,66 \\
\hline Outros & 0,0 & 0,6 & 0,04 \\
\hline Açúcares, doces e confeitaria & 14,9 & 26,1 & 0,57 \\
\hline Açúcares & 11,4 & 25,2 & 0,45 \\
\hline Açúcar cristal & 6,7 & 0,0 & - \\
\hline Açúcar demerara & 0,4 & 0,0 & - \\
\hline Açúcar não especificado & 0,1 & 0,0 & - \\
\hline Açúcar refinado & 4,1 & 24,0 & 0,17 \\
\hline Outros & 0,0 & 1,2 & 0,03 \\
\hline Doces e produtos de confeitaria & 2,7 & 0,9 & 2,97 \\
\hline Bombom & 0,3 & 0,0 & - \\
\hline Chocolate em tablete & 0,2 & 0,0 & - \\
\hline Doce a base de leite & 0,1 & 0,0 & - \\
\hline Doce de fruta cristalizado & - & 0,0 & - \\
\hline Doce de fruta em calda & 0,0 & 0,0 & - \\
\hline Doce de fruta em pasta & 0,1 & 0,9 & 0,09 \\
\hline Rapadura & 0,0 & 0,0 & - \\
\hline Sorvete & 1,4 & 0,0 & - \\
\hline
\end{tabular}


Tabela 20 (cont.): Evolução na aquisição alimentar domiciliar anual em São Paulo (ENDEF 1974/1975 - POF 2008/2009)

\begin{tabular}{|c|c|c|c|}
\hline Produtos (Kg per capita/ano) & $\begin{array}{c}\text { POF } \\
\text { 2008/2009 } \\
\text { (Município de São Paulo) }\end{array}$ & $\begin{array}{c}\text { ENDEF } \\
1974 / 1975 \\
\text { (Região Metropolitana SP) }\end{array}$ & POF/ ENDEF \\
\hline Outros & 0,5 & 0,0 & - \\
\hline Outros açúcares, doces, confeitaria & 0,8 & 0,0 & - \\
\hline Chocolate em pó & 0,7 & 0,0 & - \\
\hline Gelatina & 0,1 & 0,0 & - \\
\hline Mel de abelha & - & 0,0 & - \\
\hline Polpa de fruta & 0,0 & 0,0 & - \\
\hline Outros & - & 0,0 & - \\
\hline Sais e condimentos & 5,3 & 7,1 & 0,75 \\
\hline Sais & 1,0 & 4,4 & 0,24 \\
\hline Sal grosso & 0,0 & 0,0 & - \\
\hline Sal refinado & 1,0 & 4,4 & 0,23 \\
\hline Outros & 0,0 & 0,0 & - \\
\hline Condimentos & 4,3 & 2,7 & 1,59 \\
\hline Caldo de carne em tablete & 0,1 & 0,0 & - \\
\hline Caldo de galinha em tablete & 0,0 & 0,0 & - \\
\hline Outros caldos em tablete & 0,0 & 0,0 & - \\
\hline Colorau & 0,0 & 0,0 & - \\
\hline Fermento & 0,0 & 0,0 & - \\
\hline Leite de coco & 0,1 & 0,0 & - \\
\hline Maionese & 0,5 & 0,0 & - \\
\hline Massa de tomate & 0,6 & 1,4 & 0,46 \\
\hline Molho de tomate & 1,9 & 0,0 & - \\
\hline Tempero misto & 0,2 & 0,0 & - \\
\hline Vinagre de álcool & 0,0 & 0,0 & - \\
\hline Vinagre de vinho & 0,1 & 0,8 & 0,16 \\
\hline Vinagre não especificado & 0,4 & 0,0 & - \\
\hline Outros & 0,2 & 0,5 & 0,42 \\
\hline Óleos e Gorduras & 8,1 & 6,3 & 1,29 \\
\hline Óleos & 6,1 & 3,3 & 1,84 \\
\hline Azeite de oliva & 0,4 & 0,0 & - \\
\hline Óleo de girassol & 0,1 & 0,0 & - \\
\hline Óleo de canola & 0,2 & 0,0 & - \\
\hline Óleo de milho & 0,4 & 0,0 & - \\
\hline Óleo de soja & 4,8 & 0,0 & - \\
\hline Óleo não especificado & 0,1 & 0,0 & - \\
\hline Outros & 0,0 & 3,3 & 0,01 \\
\hline Gorduras & 2,1 & 3,0 & 0,69 \\
\hline Banha de porco & 0,0 & 1,1 & 0,01 \\
\hline Margarina vegetal & 2,0 & 1,9 & 1,08 \\
\hline Outras & 0,0 & 0,0 & - \\
\hline Alimentos preparados e misturas & 5,3 & 0,0 & - \\
\hline Alimentos preparados & 5,0 & 0,0 & - \\
\hline Alimento congelado & 0,2 & 0,0 & - \\
\hline Batata frita & 0,2 & 0,0 & - \\
\hline Carne-assada & 0,1 & 0,0 & - \\
\hline Frango assado ou defumado & 1,3 & 0,0 & - \\
\hline Frango empanado & 0,1 & 0,0 & - \\
\hline Massa & 1,2 & 0,0 & - \\
\hline Refeição & 0,6 & 0,0 & - \\
\hline Salgadinho & 0,7 & 0,0 & - \\
\hline Sanduíche & 0,3 & 0,0 & - \\
\hline Outros & 0,3 & 0,0 & - \\
\hline Misturas industriais & 0,3 & 0,0 & - \\
\hline Mistura para bolo & 0,3 & 0,0 & - \\
\hline Outras & 0,0 & 0,0 & - \\
\hline Outros produtos & 0,0 & 0,0 & - \\
\hline SUBTOTAL & 240,3 & 367,7 & 0,65 \\
\hline
\end{tabular}


Tabela 20 (cont.): Evolução na aquisição alimentar domiciliar anual em São Paulo (ENDEF 1974/1975 - POF 2008/2009)

\begin{tabular}{|c|c|c|c|}
\hline Produtos (Kg per capita/ano) & $\begin{array}{c}\text { POF } \\
\text { 2008/2009 } \\
\text { (Município de São Paulo) }\end{array}$ & $\begin{array}{c}\text { ENDEF } \\
1974 / 1975 \\
\text { (Região Metropolitana SP) }\end{array}$ & POF/ ENDEF \\
\hline Bebidas e infusões & 55,5 & \begin{tabular}{|c|}
17,4 \\
\end{tabular} & 3,19 \\
\hline Bebidas alcoólicas & 6,2 & 3,1 & 2,01 \\
\hline Aguardente de cana & 0,1 & 0,0 & - \\
\hline Outras aguardentes & - & 0,0 & - \\
\hline Cerveja & 5,3 & 2,2 & 2,40 \\
\hline Vinho & 0,6 & 0,0 & - \\
\hline Outras & 0,2 & 0,9 & 0,24 \\
\hline Bebidas não alcoólicas & 46,3 & 8,5 & 5,45 \\
\hline Água mineral & 10,4 & 8,5 & 1,22 \\
\hline Refrigerante de cola & 18,0 & 0,0 & - \\
\hline Refrigerante de guaraná & 5,1 & 0,0 & - \\
\hline Refrigerante de laranja & 1,0 & 0,0 & - \\
\hline Refrigerante de limão & 2,1 & 0,0 & - \\
\hline Refrigerante de maçã & 0,1 & 0,0 & - \\
\hline Refrigerante de uva & 0,4 & 0,0 & - \\
\hline Bebida energética & 0,2 & 0,0 & - \\
\hline Refrigerante não especificado & 3,0 & 8,3 & 0,36 \\
\hline Outros refrigerantes & 0,7 & 0,0 & - \\
\hline Suco de fruta em pó & 0,4 & 0,0 & - \\
\hline Suco de fruta envasado & 4,4 & 0,2 & 22,24 \\
\hline Outras & 0,5 & 0,0 & - \\
\hline Cafés & 2,9 & 5,6 & 0,51 \\
\hline Café moído & 2,7 & 0,0 & - \\
\hline Café solúvel & 0,2 & 0,0 & - \\
\hline Outros & 0,0 & 5,6 & 0,00 \\
\hline Chás & 0,1 & 0,2 & 0,56 \\
\hline Chá-mate & 0,1 & 0,0 & - \\
\hline Outros & 0,0 & 0,2 & 0,05 \\
\hline TOTAL & 295,8 & 385,1 & 0,77 \\
\hline
\end{tabular}

Fontes: IBGE, Diretoria de Pesquisas, Coordenação de Trabalho e Rendimento, Pesquisa de Orçamentos Familiares 2008-2009; Estudo Nacional da Despesa Familiar, 1974-1975

Nota: Os dados do Endef referem-se à Região Metropolitana de São Paulo, enquanto que a POF 2008/2009 apenas à capital

As quantidades de produtos adquiridos na forma líquida foram transformadas em $\mathrm{kg}$, considerando-se volume igual a peso. 
ANEXO B

Tabela 21: Aquisição alimentar domiciliar anual - Brasil e Capitais

\begin{tabular}{|c|c|c|c|c|c|c|c|c|c|}
\hline Produtos & Brasil & $\begin{array}{c}\text { São } \\
\text { Paulo }\end{array}$ & \begin{tabular}{|c|} 
Belo \\
Horizonte
\end{tabular} & $\begin{array}{c}\text { Rio de } \\
\text { Janeiro }\end{array}$ & $\begin{array}{l}\text { Porto } \\
\text { Alegre }\end{array}$ & Cuiabá & Manaus & Salvador & $\begin{array}{c}\text { SP/ } \\
\text { Brasil }\end{array}$ \\
\hline Cereais e leguminosas & 39,0 & 24,5 & 23,0 & 27,7 & 23,3 & 34,9 & 29,6 & 19,3 & 0,6 \\
\hline Cereais & 29,4 & 19,2 & 17,6 & 19,0 & 17,3 & 28,6 & 19,9 & 10,6 & 0,7 \\
\hline Arroz não especificado & 11,9 & 8,0 & 6,8 & 4,1 & 4,5 & 5,4 & 14,3 & 5,2 & 0,7 \\
\hline Arroz polido & 14,6 & 10,7 & 9,6 & 14,0 & 11,1 & 22,6 & 5,5 & 4,5 & 0,7 \\
\hline Milho em grão & 2,1 & 0,3 & 0,4 & 0,3 & 1,2 & 0,1 & 0,1 & 0,4 & 0,1 \\
\hline Milho verde em conserva & 0,2 & 0,2 & 0,4 & 0,2 & 0,2 & 0,3 & 0,1 & 0,2 & 1,1 \\
\hline Milho verde em espiga & 0,5 & 0,0 & 0,4 & 0,2 & 0,3 & 0,2 & - & 0,3 & 0,0 \\
\hline Outros & 0,1 & 0,0 & 0,1 & 0,1 & 0,0 & 0,1 & - & - & 0,4 \\
\hline Leguminosas & 9,6 & 5,3 & 5,3 & 8,7 & 6,0 & 6,3 & 9,7 & 8,7 & 0,6 \\
\hline Feijão-fradinho & 1,2 & 0,1 & - & 0,1 & - & 0,4 & 0,0 & 1,5 & 0,1 \\
\hline Feijão-jalo & 0,1 & 0,1 & 0,1 & 0,1 & 0,0 & 0,0 & 1,1 & - & 0,8 \\
\hline Feijão-manteiga & 0,3 & 0,2 & 0,0 & 0,1 & 0,1 & 0,1 & 0,1 & 0,2 & 0,9 \\
\hline Feijão-mulatinho & 0,6 & 1,0 & 0,1 & 0,1 & 0,3 & 0,2 & 0,1 & 3,4 & 1,7 \\
\hline Feijão-preto & 2,0 & 0,4 & 0,2 & 7,0 & 4,6 & 1,6 & 0,8 & 0,7 & 0,2 \\
\hline Feijão-rajado & 3,9 & 3,1 & 2,8 & 0,6 & 0,1 & 3,8 & 2,2 & 2,2 & 0,8 \\
\hline Feijão-roxo & 0,0 & 0,0 & - & - & 0,0 & - & - & - & 1,3 \\
\hline Outros feijões & 1,1 & - & 1,7 & - & - & 0,0 & 5,3 & 0,1 & - \\
\hline Outras & 0,4 & 0,3 & 0,4 & 0,8 & 0,7 & 0,1 & 0,1 & 0,7 & 0,8 \\
\hline Hortaliças & 27,1 & 26,7 & 30,3 & 34,4 & 37,5 & 29,3 & 14,5 & 26,9 & 1,0 \\
\hline Hortaliças folhosas e florais & 3,2 & 3,5 & 4,0 & 4,4 & 5,1 & 3,2 & 1,2 & 2,5 & 1,1 \\
\hline Acelga & 0,0 & 0,1 & - & - & - & 0,1 & - & 0,0 & 2,9 \\
\hline Agrião & 0,1 & 0,1 & 0,1 & 0,6 & 0,2 & 0,2 & - & - & 1,5 \\
\hline Alface & 0,9 & 1,3 & 1,1 & 0,9 & 1,5 & 1,1 & 0,1 & 0,4 & 1,4 \\
\hline Cheiro-verde & 0,2 & 0,1 & 0,1 & 0,2 & 0,2 & 0,2 & 0,4 & 0,2 & 0,4 \\
\hline Couve & 0,3 & 0,3 & 0,6 & 0,6 & 0,5 & 0,2 & 0,2 & 0,2 & 1,0 \\
\hline Couve-brócolis & 0,1 & 0,4 & 0,5 & 0,6 & 0,8 & 0,1 & 0,0 & 0,1 & 2,5 \\
\hline Couve-flor & 0,2 & 0,2 & 0,4 & 0,4 & 0,2 & 0,1 & - & 0,0 & 1,3 \\
\hline Repolho & 1,0 & 0,6 & 0,7 & 0,9 & 1,2 & 0,9 & 0,3 & 1,2 & 0,5 \\
\hline Outras & 0,4 & 0,4 & 0,6 & 0,4 & 0,5 & 0,3 & 0,1 & 0,4 & 1,0 \\
\hline Hortaliças frutosas & 12,6 & 12,7 & 13,4 & 15,9 & 16,2 & 14,2 & 8,5 & 15,9 & 1,0 \\
\hline Abóbora & 1,2 & 0,5 & 2,3 & 1,5 & 2,5 & 0,9 & 0,2 & 1,5 & 0,4 \\
\hline Abobrinha & 0,4 & 0,9 & 0,7 & 0,6 & 0,2 & 0,5 & 0,0 & 0,2 & 2,4 \\
\hline Azeitona em conserva & 0,1 & 0,3 & 0,2 & 0,2 & 0,1 & 0,3 & 0,0 & 0,0 & 2,4 \\
\hline Berinjela & 0,2 & 0,4 & 0,3 & 0,6 & 0,1 & 0,2 & 0,0 & 0,1 & 2,3 \\
\hline Cebola & 3,2 & 2,8 & 2,8 & 3,8 & 4,3 & 3,3 & 3,7 & 3,8 & 0,9 \\
\hline Chuchu & 0,8 & 0,7 & 1,1 & 1,8 & 1,1 & 0,6 & - & 1,4 & 0,9 \\
\hline Jiló & 0,1 & 0,1 & 0,2 & 0,2 & - & 0,1 & - & 0,1 & 1,0 \\
\hline Maxixe & 0,1 & 0,0 & - & - & - & 0,1 & 0,1 & 0,1 & 0,3 \\
\hline Pepino fresco & 0,5 & 0,7 & 0,2 & 0,4 & 0,3 & 0,4 & 0,4 & 0,9 & 1,4 \\
\hline Pimentão & 0,6 & 0,6 & 0,4 & 0,8 & 0,7 & 0,5 & 0,5 & 1,6 & 1,1 \\
\hline Quiabo & 0,3 & 0,1 & 0,5 & 0,2 & 0,0 & 0,3 & 0,0 & 0,9 & 0,3 \\
\hline Tomate & 4,9 & 5,1 & 4,2 & 5,3 & 6,7 & 6,7 & 3,1 & 5,3 & 1,0 \\
\hline Vagem & 0,2 & 0,2 & 0,2 & 0,5 & 0,0 & 0,3 & - & 0,0 & 1,4 \\
\hline Outras & 0,4 & 0,1 & 0,2 & 0,0 & 0,1 & 0,0 & 0,3 & 0,0 & 0,3 \\
\hline Hortaliças tuberosas e outras & 11,3 & 10,6 & 12,9 & 14,0 & 16,3 & 11,9 & 4,8 & 8,5 & 0,9 \\
\hline Alho & 0,5 & 0,5 & 0,7 & 0,9 & 0,2 & 0,8 & 0,3 & 0,2 & 0,9 \\
\hline Batata-aipo & 0,1 & 0,4 & - & - & - & - & - & - & 5,2 \\
\hline Batata-baroa & 0,1 & 0,0 & 0,5 & 0,2 & 0,0 & - & - & - & 0,1 \\
\hline Batata-doce & 0,6 & 0,2 & 0,3 & 0,4 & 1,0 & 0,8 & 0,2 & 0,9 & 0,2 \\
\hline Batata-inglesa & 4,0 & 3,4 & 4,6 & 7,2 & 6,0 & 4,3 & 2,2 & 2,7 & 0,8 \\
\hline Batata não especificada & 1,6 & 2,9 & 1,7 & 0,8 & 2,4 & 0,9 & 0,7 & 1,3 & 1,8 \\
\hline Beterraba & 0,5 & 0,5 & 0,6 & 0,5 & 0,9 & 0,8 & 0,3 & 0,3 & 0,9 \\
\hline Cará & 0,1 & 0,0 & 0,5 & - & - & - & 0,1 & 0,1 & 0,2 \\
\hline Cenoura & 1,6 & 1,9 & 2,2 & 2,5 & 1,8 & 2,1 & 0,7 & 1,5 & 1,2 \\
\hline Inhame & 0,4 & 0,1 & 0,4 & 0,7 & - & 0,1 & - & 0,4 & 0,4 \\
\hline Mandioca & 1,8 & 0,6 & 1,2 & 0,6 & 3,8 & 2,0 & 0,3 & 1,0 & 0,4 \\
\hline Outras & 0,4 & 0,2 & 0,2 & 0,3 & 0,3 & 0,1 & 0,0 & 0,1 & 0,4 \\
\hline Frutas & 28,9 & 37,1 & 43,1 & 38,5 & 40,8 & 35,7 & 20,0 & 28,2 & 1,3 \\
\hline Frutas de clima tropical & 24,8 & 31,4 & 37,7 & 32,5 & 33,9 & 29,4 & 17,2 & 25,2 & 1,3 \\
\hline Abacate & 0,3 & 0,4 & 0,3 & 0,2 & 0,0 & 0,3 & 0,5 & 0,0 & 1,5 \\
\hline Abacaxi & 1,5 & 1,1 & 1,9 & 2,2 & 1,9 & 2,1 & 0,7 & 1,6 & 0,7 \\
\hline Acerola & 0,1 & - & - & - & - & - & 0,2 & 0,4 & - \\
\hline Banana-d'água & 2,2 & 4,5 & 1,7 & 1,0 & 5,5 & 3,5 & 0,0 & 0,2 & 2,1 \\
\hline Banana-da-terra & 0,4 & 0,0 & 0,0 & 0,2 & 0,1 & 0,7 & 0,6 & 1,4 & 0,0 \\
\hline Banana-maçã & 0,3 & 0,2 & 0,0 & 0,1 & 0,1 & 0,5 & 0,3 & 0,0 & 0,6 \\
\hline Banana-ouro & 0,0 & - & - & - & - & 0,0 & - & - & - \\
\hline
\end{tabular}


Tabela 21 (cont.): Aquisição alimentar domiciliar anual - Brasil e Capitais

\begin{tabular}{|c|c|c|c|c|c|c|c|c|c|}
\hline Produtos & Brasil & $\begin{array}{l}\text { São } \\
\text { Paulo }\end{array}$ & \begin{tabular}{c|} 
Belo \\
Horizonte
\end{tabular} & $\begin{array}{l}\text { Rio de } \\
\text { Janeiro }\end{array}$ & $\begin{array}{l}\text { Porto } \\
\text { Alegre }\end{array}$ & Cuiabá & Manaus & Salvador & $\begin{array}{c}\text { SP/ } \\
\text { Brasil }\end{array}$ \\
\hline Banana-prata & 2,8 & 2,4 & 3,5 & 6,0 & 1,6 & 0,2 & 1,6 & 4,5 & 0,9 \\
\hline Outras bananas & 1,9 & 1,9 & 3,3 & 1,5 & 2,3 & 1,1 & 1,4 & 1,3 & 1,0 \\
\hline Goiaba & 0,4 & 0,4 & 0,4 & 0,5 & - & 0,0 & 0,0 & 0,5 & 1,1 \\
\hline Laranja-baía & 0,2 & 0,0 & 0,2 & - & 2,9 & 0,3 & 0,2 & 0,1 & 0,1 \\
\hline Laranja-lima & 0,4 & 1,1 & 0,2 & 1,3 & 0,6 & 0,1 & 0,0 & 0,0 & 2,8 \\
\hline Laranja-pera & 2,8 & 5,7 & 5,2 & 4,8 & 1,4 & 3,1 & 1,2 & 2,5 & 2,0 \\
\hline Laranja-seleta & 0,1 & - & 0,1 & 0,6 & 0,1 & - & 0,2 & - & - \\
\hline Outras Iaranjas & 2,0 & 2,0 & 4,7 & 1,3 & 2,4 & 4,6 & 2,6 & 1,2 & 1,0 \\
\hline Limão comum & 0,6 & 1,2 & 0,8 & 1,1 & 0,5 & 0,6 & 1,1 & 0,8 & 2,1 \\
\hline Mamão & 2,0 & 3,2 & 4,8 & 3,4 & 6,0 & 1,8 & 0,6 & 2,8 & 1,6 \\
\hline Manga & 1,0 & 1,2 & 2,6 & 1,7 & 1,5 & 0,3 & 0,1 & 1,0 & 1,2 \\
\hline Maracujá & 0,3 & 0,2 & 0,4 & 0,2 & 0,1 & 0,2 & 0,4 & 0,8 & 0,6 \\
\hline Melancia & 3,4 & 3,4 & 4,7 & 3,1 & 1,2 & 7,2 & 4,8 & 3,7 & 1,0 \\
\hline Melão & 0,5 & 0,6 & 0,7 & 0,8 & 0,9 & 1,3 & 0,2 & 0,5 & 1,2 \\
\hline Tangerina & 1,2 & 1,7 & 1,8 & 1,9 & 4,7 & 1,4 & 0,3 & 0,7 & 1,5 \\
\hline Outras & 0,4 & 0,2 & 0,2 & 0,6 & 0,3 & 0,1 & 0,1 & 1,1 & 0,5 \\
\hline Frutas de clima temperado & 4,0 & 5,6 & 5,4 & 6,0 & 6,9 & 6,3 & 2,9 & 3,0 & 1,4 \\
\hline Ameixa & 0,1 & 0,2 & 0,2 & 0,2 & 0,2 & 0,3 & 0,0 & 0,1 & 1,3 \\
\hline Caqui & 0,2 & 0,4 & 0,1 & 0,3 & 0,5 & 0,2 & - & 0,0 & 2,5 \\
\hline Maçã & 2,1 & 2,4 & 3,1 & 3,0 & 3,6 & 3,4 & 1,9 & 1,7 & 1,1 \\
\hline Morango & 0,2 & 0,3 & 0,3 & 0,2 & 0,2 & 0,1 & - & 0,1 & 1,7 \\
\hline Pera & 0,4 & 0,8 & 0,5 & 0,8 & 0,3 & 0,6 & 0,2 & 0,3 & 2,3 \\
\hline Pêssego & 0,2 & 0,5 & 0,3 & 0,1 & 1,0 & 0,2 & - & - & 2,2 \\
\hline Uva & 0,8 & 0,9 & 0,7 & 1,1 & 0,8 & 1,6 & 0,6 & 0,7 & 1,2 \\
\hline Outras & 0,4 & 0,2 & 0,1 & 0,2 & 0,2 & 0,1 & - & 0,1 & 0,4 \\
\hline Cocos, castanhas e nozes & 1,3 & 0,3 & 0,3 & 0,2 & 0,1 & 0,1 & 0,7 & 0,6 & 0,2 \\
\hline Cocos & 1,2 & 0,2 & 0,2 & 0,1 & 0,0 & 0,0 & 0,7 & 0,5 & 0,2 \\
\hline Açaí (emulsão) & 0,8 & 0,1 & - & - & - & - & 0,4 & - & 0,1 \\
\hline Coco-da-baía & 0,1 & 0,0 & 0,1 & 0,1 & - & - & 0,3 & 0,3 & 0,2 \\
\hline Outros & 0,1 & 0,1 & 0,1 & 0,0 & 0,0 & 0,0 & 0,1 & 0,3 & 0,6 \\
\hline Castanhas e nozes & 0,1 & 0,0 & 0,1 & 0,1 & 0,1 & 0,1 & - & 0,1 & 0,6 \\
\hline Farinhas, féculas e massas & 18,1 & 7,9 & 9,0 & 10,6 & 8,4 & 10,9 & 26,2 & 12,6 & 0,4 \\
\hline Farinhas & 9,0 & 2,3 & 2,2 & 3,8 & 2,7 & 5,0 & 13,9 & 7,0 & 0,3 \\
\hline Farinha de mandioca & 5,3 & 0,5 & 0,4 & 1,5 & 0,4 & 1,5 & 11,6 & 5,1 & 0,1 \\
\hline Farinha de rosca & 0,1 & 0,1 & - & 0,1 & - & - & - & 0,0 & 1,7 \\
\hline Farinha de trigo & 3,4 & 1,6 & 1,4 & 1,9 & 2,0 & 3,4 & 1,9 & 1,2 & 0,5 \\
\hline Farinha vitaminada & 0,1 & 0,0 & 0,2 & 0,2 & 0,2 & 0,1 & 0,3 & 0,2 & 0,4 \\
\hline Outras & 0,4 & 0,0 & 0,2 & 0,2 & 0,1 & 0,0 & 0,1 & 0,4 & 0,1 \\
\hline Féculas & 4,3 & 1,2 & 1,9 & 1,6 & 1,2 & 1,6 & 4,9 & 2,5 & 0,3 \\
\hline Amido de milho & 0,1 & 0,1 & 0,1 & 0,1 & 0,0 & 0,1 & 0,1 & 0,0 & 1,0 \\
\hline Creme de arroz & 0,1 & 0,0 & 0,0 & 0,1 & 0,2 & 0,1 & 0,3 & 0,2 & 0,2 \\
\hline Creme de milho & 0,2 & 0,0 & - & 0,1 & - & 0,0 & 0,0 & 0,2 & 0,0 \\
\hline Fécula de mandioca & 0,8 & 0,1 & 0,2 & 0,0 & 0,1 & 0,3 & 1,3 & 0,3 & 0,1 \\
\hline Flocos de aveia & 0,1 & 0,0 & 0,1 & 0,2 & 0,2 & 0,1 & 0,0 & 0,2 & 0,6 \\
\hline Flocos de milho & 0,6 & 0,6 & 0,4 & 0,0 & 0,2 & 0,2 & 0,0 & 0,3 & 0,9 \\
\hline Flocos de outros cereais & 0,1 & 0,0 & 0,4 & 0,2 & 0,1 & 0,2 & 0,1 & 0,2 & 0,4 \\
\hline Fubá de milho & 2,3 & 0,3 & 0,8 & 0,8 & 0,4 & 0,6 & 3,0 & 1,1 & 0,1 \\
\hline Outras & 0,4 & 0,0 & 0,0 & - & - & - & - & - & 0,0 \\
\hline Massas & 4,7 & 4,4 & 4,9 & 5,2 & 4,5 & 4,3 & 7,4 & 3,1 & 0,9 \\
\hline Macarrão com ovos & 1,1 & 1,5 & 1,6 & 2,5 & 1,0 & 1,4 & 0,8 & 0,4 & 1,4 \\
\hline Macarrão não especificado & 2,7 & 2,4 & 2,0 & 1,5 & 1,8 & 1,8 & 5,9 & 1,9 & 0,9 \\
\hline Macarrão sem ovos & 0,3 & 0,0 & 0,2 & 0,1 & 0,2 & 0,4 & 0,5 & 0,4 & 0,0 \\
\hline Massa de lasanha & 0,2 & 0,1 & 0,7 & 0,4 & 0,4 & 0,2 & 0,1 & 0,1 & 0,6 \\
\hline Massa de pastel & 0,1 & 0,1 & 0,1 & 0,4 & 0,6 & 0,1 & - & 0,1 & 0,7 \\
\hline Massa de pizza & 0,2 & 0,2 & 0,3 & 0,1 & 0,2 & 0,5 & 0,1 & 0,1 & 1,1 \\
\hline Outras & 0,4 & 0,1 & 0,1 & 0,1 & 0,2 & 0,1 & 0,0 & 0,1 & 0,3 \\
\hline Panificados & 21,5 & 26,7 & 27,5 & 28,1 & 28,4 & 18,3 & 31,3 & 31,6 & 1,2 \\
\hline Pães & 15,8 & 21,4 & 21,8 & 21,6 & 22,2 & 14,3 & 26,6 & 26,6 & 1,4 \\
\hline Pão cas eiro & 0,3 & 0,0 & 0,0 & 0,0 & 0,1 & 0,6 & 0,7 & 0,4 & 0,1 \\
\hline Pão de forma de padaria & 0,1 & 0,0 & 0,0 & 0,0 & 0,1 & 0,2 & 0,2 & 0,0 & 0,1 \\
\hline Pão de forma industrializado & 0,9 & 1,7 & 1,7 & 3,2 & 3,3 & 0,8 & 0,2 & 0,2 & 2,0 \\
\hline Pão de milho & 0,1 & 0,1 & 0,0 & 0,2 & 0,1 & 0,0 & 0,1 & 0,9 & 0,8 \\
\hline Pão de queijo & 0,2 & 0,2 & 0,8 & 0,2 & 0,3 & 0,2 & 0,3 & 0,0 & 1,0 \\
\hline Pão doce & 0,9 & 2,0 & 2,1 & 1,2 & 1,5 & 0,8 & 0,6 & 1,0 & 2,2 \\
\hline Pão francês & 12,5 & 16,6 & 16,3 & 15,4 & 15,2 & 11,3 & 23,7 & 23,0 & 1,3 \\
\hline Pão integral & 0,2 & 0,3 & 0,4 & 0,4 & 0,7 & 0,2 & 0,5 & 0,6 & 1,4 \\
\hline
\end{tabular}


Tabela 21 (cont.): Aquisição alimentar domiciliar anual - Brasil e Capitais

\begin{tabular}{|c|c|c|c|c|c|c|c|c|c|}
\hline Produtos & Brasil & $\begin{array}{c}\text { São } \\
\text { Paulo }\end{array}$ & \begin{tabular}{|c|} 
Belo \\
Horizonte
\end{tabular} & $\begin{array}{c}\text { Rio de } \\
\text { Janeiro }\end{array}$ & $\begin{array}{c}\text { Porto } \\
\text { Alegre }\end{array}$ & Cuiabá & Manaus & Salvador & $\begin{array}{c}\text { SP/ } \\
\text { Brasil }\end{array}$ \\
\hline Torrada & 0,1 & 0,1 & 0,1 & 0,2 & 0,1 & 0,1 & 0,2 & 0,1 & 1,4 \\
\hline Outros & 0,1 & 0,5 & 0,3 & 0,9 & 0,9 & 0,2 & 0,1 & 0,3 & 4,1 \\
\hline Bolos & 0,9 & 1,0 & 0,8 & 1,1 & 1,9 & 0,3 & 0,7 & 0,4 & 1,1 \\
\hline Biscoitos, roscas, etc. & 4,8 & 4,3 & 4,9 & 5,4 & 4,4 & 3,7 & 4,0 & 4,6 & 0,9 \\
\hline Biscoito doce & 2,3 & 2,6 & 2,6 & 3,0 & 2,5 & 1,6 & 1,0 & 2,0 & 1,1 \\
\hline Biscoito não especificado & 0,2 & 0,1 & 0,5 & 0,1 & 0,1 & 0,1 & 0,0 & 0,3 & 0,4 \\
\hline Biscoito salgado & 2,0 & 1,5 & 1,4 & 2,1 & 1,6 & 1,8 & 2,9 & 2,3 & 0,7 \\
\hline Rosca doce & 0,1 & 0,0 & 0,2 & 0,1 & - & 0,0 & 0,0 & - & 0,4 \\
\hline Rosca não especificada & 0,1 & 0,0 & 0,1 & 0,0 & 0,1 & 0,1 & 0,1 & 0,0 & 0,2 \\
\hline Rosca salgada & 0,0 & - & - & 0,0 & - & - & - & 0,0 & - \\
\hline Outros & 0,1 & 0,0 & 0,0 & 0,0 & 0,0 & - & - & 0,0 & 0,3 \\
\hline Carnes & 25,4 & 21,0 & 21,2 & 27,2 & 28,5 & 26,9 & 29,8 & 18,9 & 0,8 \\
\hline Carnes bovinas de primeira & 6,1 & 6,6 & 5,9 & 8,0 & 6,5 & 8,6 & 8,3 & 3,7 & 1,1 \\
\hline Alcatra & 0,9 & 1,0 & 1,6 & 2,2 & 0,7 & 1,7 & 1,7 & 0,5 & 1,2 \\
\hline Carne moída & 0,4 & 0,5 & 0,4 & 0,5 & 1,4 & 1,1 & 0,9 & 0,1 & 1,4 \\
\hline Carne não especificada & 2,5 & 1,5 & 1,1 & 2,1 & 2,6 & 3,0 & 3,7 & 1,9 & 0,6 \\
\hline Chã de dentro & 0,6 & 1,6 & 0,6 & 0,3 & 0,3 & 0,8 & 0,4 & 0,4 & 2,4 \\
\hline Contrafilé & 0,8 & 0,6 & 1,1 & 1,7 & 0,6 & 0,6 & 1,3 & 0,2 & 0,8 \\
\hline Filé-mignon & 0,1 & 0,2 & 0,5 & 0,5 & 0,6 & 0,6 & 0,1 & 0,0 & 1,5 \\
\hline Lagarto comum & 0,2 & 0,6 & 0,2 & 0,2 & 0,0 & 0,2 & 0,1 & 0,1 & 2,7 \\
\hline Lagarto redondo & 0,0 & - & 0,0 & 0,1 & - & 0,1 & - & 0,1 & - \\
\hline Patinho & 0,4 & 0,6 & 0,4 & 0,4 & 0,1 & 0,7 & 0,2 & 0,4 & 1,4 \\
\hline Carnes bovinas de segunda & 6,9 & 5,9 & 3,8 & 6,1 & 9,3 & 8,6 & 7,0 & 4,5 & 0,9 \\
\hline Acém & 0,7 & 2,4 & 0,3 & 0,4 & 0,3 & 0,0 & 1,1 & 0,3 & 3,4 \\
\hline Capa de filé & 0,1 & 0,2 & 0,0 & 0,0 & 0,2 & 0,4 & 0,1 & - & 2,1 \\
\hline Carne moída & 0,4 & 0,7 & 0,8 & 1,5 & 2,1 & 1,2 & 1,7 & 0,2 & 2,1 \\
\hline Carne não especificada & 2,5 & 0,3 & 0,6 & 1,7 & 2,4 & 1,7 & 2,3 & 1,5 & 0,1 \\
\hline Costela & 1,5 & 1,2 & 0,6 & 0,8 & 2,3 & 4,3 & 0,7 & 0,6 & 0,8 \\
\hline Músculo & 0,4 & 0,5 & 0,7 & 0,5 & 0,5 & 0,2 & 0,1 & 0,3 & 1,3 \\
\hline Pá & 0,3 & 0,2 & 0,4 & 0,3 & 1,2 & 0,3 & 0,1 & 0,5 & 0,6 \\
\hline Peito & 0,2 & 0,1 & 0,1 & 0,3 & 0,1 & 0,2 & 0,2 & 0,2 & 0,6 \\
\hline Outras & 0,4 & 0,3 & 0,1 & 0,5 & 0,1 & 0,3 & 0,8 & 0,8 & 0,6 \\
\hline Carnes bovinas outras & 4,1 & 1,8 & 1,9 & 3,1 & 3,6 & 3,1 & 8,1 & 5,1 & 0,4 \\
\hline Carne de hambúrguer & 0,2 & 0,3 & 0,3 & 0,8 & 0,2 & 0,2 & 0,1 & 0,1 & 1,4 \\
\hline Carne de sol & 0,3 & - & 0,0 & - & - & 0,0 & 0,0 & 0,7 & - \\
\hline Carne moída não especificada & 0,4 & 0,2 & 0,4 & 0,6 & 0,0 & 0,1 & 1,3 & 0,3 & 0,5 \\
\hline Carne não especificada & 2,5 & 0,6 & 0,8 & 0,6 & 1,9 & 0,5 & 1,1 & 1,7 & 0,2 \\
\hline Carne-seca & 0,5 & 0,1 & 0,1 & 0,7 & - & 0,0 & 0,5 & 1,4 & 0,2 \\
\hline Mocotó & 0,1 & 0,0 & - & 0,1 & - & 0,1 & 0,2 & 0,2 & 0,6 \\
\hline Outras & 0,4 & 0,6 & 0,3 & 0,2 & 1,4 & 2,1 & 4,9 & 0,7 & 1,3 \\
\hline Carnes suínas com osso e sem osso & 2,3 & 1,3 & 2,3 & 2,1 & 1,8 & 1,4 & 0,5 & 0,2 & 0,6 \\
\hline Carré & 0,3 & 0,6 & 0,0 & 1,2 & 0,3 & 0,2 & 0,3 & 0,0 & 1,9 \\
\hline Costela & 1,5 & 0,4 & 0,5 & 0,2 & 0,4 & 0,1 & - & 0,1 & 0,3 \\
\hline Lombo & 0,1 & 0,0 & 0,4 & 0,3 & 0,1 & 0,1 & - & - & 0,3 \\
\hline Pernil & 0,3 & 0,2 & 0,6 & 0,1 & 0,3 & 0,2 & 0,1 & 0,0 & 0,6 \\
\hline Porco evis cerado & 0,2 & - & - & - & - & - & - & - & - \\
\hline Outras & 0,4 & 0,1 & 0,8 & 0,2 & 0,7 & 0,8 & 0,2 & 0,1 & 0,3 \\
\hline Carnes suínas outras & 3,2 & 3,3 & 4,2 & 4,5 & 5,0 & 2,5 & 2,3 & 3,0 & 1,0 \\
\hline Carne salgada não especificada & 0,1 & 0,0 & 0,4 & 0,1 & 0,1 & 0,1 & 0,1 & 0,4 & 0,4 \\
\hline Costela de porco salgada & 0,0 & 0,1 & 0,0 & 0,2 & - & 0,1 & 0,1 & 0,1 & 2,3 \\
\hline Mortadela & 0,8 & 0,6 & 0,5 & 0,9 & 1,8 & 0,5 & 0,1 & 0,3 & 0,7 \\
\hline Paio & 0,0 & 0,0 & 0,0 & 0,0 & - & - & - & 0,0 & 2,5 \\
\hline Pé de porco salgado & 0,0 & 0,0 & 0,0 & 0,0 & 0,0 & - & - & 0,0 & 1,1 \\
\hline Presunto & 0,5 & 0,6 & 1,1 & 0,8 & 0,7 & 0,8 & 0,5 & 0,6 & 1,3 \\
\hline Salame & 0,2 & 0,1 & 0,1 & 0,1 & 0,2 & 0,1 & 0,0 & 0,0 & 0,5 \\
\hline Salsicha comum & 1,2 & 1,6 & 1,2 & 2,0 & 1,8 & 0,7 & 1,5 & 0,9 & 1,4 \\
\hline Toucinho fresco & 0,2 & - & 0,3 & 0,1 & - & 0,1 & - & 0,1 & - \\
\hline Toucinho defumado & 0,1 & 0,1 & 0,4 & 0,2 & 0,1 & 0,1 & 0,0 & 0,3 & 1,2 \\
\hline Outras & 0,4 & 0,0 & 0,1 & 0,1 & 0,2 & 0,1 & 0,1 & 0,2 & 0,1 \\
\hline Carnes de outros animais & 2,8 & 2,1 & 3,2 & 3,3 & 2,4 & 2,7 & 3,6 & 2,3 & 0,7 \\
\hline Carne de cabrito & 0,1 & - & - & - & - & - & - & 0,1 & - \\
\hline Carne de carneiro & 0,2 & - & - & 0,0 & 0,4 & 0,2 & - & 0,1 & - \\
\hline Linguiça & 2,1 & 2,0 & 3,0 & 3,1 & 1,8 & 2,4 & 3,4 & 1,9 & 0,9 \\
\hline Outras & 0,4 & 0,1 & 0,1 & 0,2 & 0,1 & 0,1 & 0,2 & 0,2 & 0,2 \\
\hline
\end{tabular}


Tabela 21 (cont.): Aquisição alimentar domiciliar anual - Brasil e Capitais

\begin{tabular}{|c|c|c|c|c|c|c|c|c|c|}
\hline Produtos & Brasil & $\begin{array}{l}\text { São } \\
\text { Paulo }\end{array}$ & \begin{tabular}{|c|} 
Belo \\
Horizonte
\end{tabular} & $\begin{array}{c}\text { Rio de } \\
\text { Janeiro }\end{array}$ & $\begin{array}{l}\text { Porto } \\
\text { Alegre }\end{array}$ & Cuiabá & Manaus & Salvador & $\begin{array}{c}\text { SP/ } \\
\text { Brasil }\end{array}$ \\
\hline Vísceras & 0,7 & 0,3 & 0,8 & 0,6 & 0,8 & 0,4 & 1,1 & 1,2 & 0,5 \\
\hline Vísceras bovinas & 0,6 & 0,3 & 0,4 & 0,6 & 0,8 & 0,4 & 1,1 & 1,1 & 0,5 \\
\hline Bucho & 0,1 & - & 0,1 & 0,1 & - & - & 0,2 & 0,1 & - \\
\hline Fígado & 0,4 & 0,3 & 0,3 & 0,4 & 0,4 & 0,4 & 0,8 & 0,9 & 0,7 \\
\hline Língua & 0,0 & - & 0,0 & - & 0,2 & - & 0,1 & - & - \\
\hline Outras & 0,4 & 0,0 & 0,1 & 0,0 & 0,1 & - & 0,1 & 0,2 & 0,1 \\
\hline Vísceras suínas & 0,1 & - & 0,4 & 0,1 & - & - & 0,0 & 0,1 & - \\
\hline Outras vísceras & 0,0 & 0,0 & - & 0,0 & - & - & - & 0,0 & 1,3 \\
\hline Pescados & 4,0 & 2,0 & 2,0 & 4,4 & 1,0 & 2,1 & 16,5 & 3,5 & 0,5 \\
\hline Pescados de água salgada & 1,9 & 1,5 & 1,3 & 3,7 & 0,7 & 0,6 & 1,1 & 3,0 & 0,8 \\
\hline Anchova fresca & 0,0 & - & - & 0,1 & - & - & - & - & - \\
\hline Bacalhau & 0,1 & 0,2 & 0,2 & 0,1 & - & - & - & 0,1 & 2,4 \\
\hline Bagre fresco & 0,1 & - & - & - & - & - & - & - & - \\
\hline Cação fresco & 0,0 & 0,1 & 0,1 & 0,1 & - & - & - & 0,0 & 3,2 \\
\hline Camarão fresco & 0,2 & 0,0 & 0,2 & 0,7 & - & 0,4 & 0,0 & 0,1 & 0,3 \\
\hline Corvina fresca & 0,1 & 0,1 & - & 0,2 & - & - & - & 0,9 & 0,6 \\
\hline Merluza em filé congelado & 0,1 & 0,1 & 0,2 & 0,1 & 0,0 & - & - & 0,1 & 1,2 \\
\hline Merluza em filé fresco & 0,0 & - & - & 0,0 & - & - & - & - & - \\
\hline Parati fresco & 0,0 & - & - & - & - & - & - & - & - \\
\hline Pescada em filé congelado & 0,0 & 0,1 & 0,0 & 0,1 & 0,0 & - & - & 0,0 & 3,3 \\
\hline Pescada em filé fresco & 0,0 & 0,1 & - & 0,0 & - & - & - & - & 7,1 \\
\hline Pescada fresca & 0,3 & 0,1 & - & 0,1 & - & - & 0,0 & 0,1 & 0,4 \\
\hline Pescadinha fresca & 0,0 & - & - & 0,1 & - & - & - & - & - \\
\hline Sardinha em conserva & 0,1 & 0,1 & 0,1 & 0,1 & 0,1 & 0,1 & 0,3 & 0,1 & 0,8 \\
\hline Sardinha fresca & 0,1 & 0,1 & - & 0,1 & - & 0,0 & 0,5 & 0,4 & 0,5 \\
\hline Tainha fresca & 0,1 & - & - & - & - & - & - & 0,1 & - \\
\hline Outros pescados em filé congelado & 0,1 & 0,2 & 0,3 & 0,5 & 0,3 & 0,0 & 0,1 & 0,1 & 1,6 \\
\hline Outros pescados em filé fresco & 0,1 & 0,2 & 0,2 & 0,3 & 0,2 & 0,0 & 0,0 & 0,1 & 1,6 \\
\hline Outros pescados frescos & 0,4 & 0,1 & 0,0 & 0,9 & - & 0,0 & 0,2 & 0,8 & 0,3 \\
\hline Outros pescados salgados & 0,0 & - & - & 0,1 & - & - & - & - & - \\
\hline Pescados de água doce & 1,6 & 0,2 & 0,4 & 0,0 & 0,3 & 1,4 & 14,5 & 0,2 & 0,1 \\
\hline Acará fresca & 0,1 & - & - & - & - & - & - & - & - \\
\hline Acari fresco & 0,0 & - & 0,2 & - & - & - & - & - & - \\
\hline Anujá fresco & 0,0 & - & - & - & - & - & - & - & - \\
\hline Curimatã fresco & 0,1 & 0,0 & - & - & - & - & 1,2 & - & 0,2 \\
\hline Dourada fresca & 0,1 & - & - & - & - & - & - & - & - \\
\hline Jaraqui fresco & 0,1 & - & - & - & - & - & 4,9 & - & - \\
\hline Lambari fresco & 0,1 & - & - & - & - & - & 0,0 & - & - \\
\hline Mapará fresco & 0,0 & - & - & - & - & - & - & - & - \\
\hline Piau fresco & 0,0 & - & - & - & - & - & - & - & - \\
\hline Surubim fresco & 0,1 & - & 0,1 & - & - & 0,4 & 0,1 & - & - \\
\hline Tambaqui fresco & 0,1 & - & - & - & - & - & 2,8 & - & - \\
\hline Tilápia fresca & 0,1 & - & - & - & - & 0,0 & - & - & - \\
\hline Traíra fresca & 0,1 & - & - & - & - & - & - & - & - \\
\hline Tucunaré fresco & 0,0 & - & - & - & - & - & 0,0 & 0,0 & - \\
\hline Outros pescados em filé congelado & 0,1 & - & 0,1 & 0,0 & 0,1 & 0,1 & 1,0 & 0,2 & - \\
\hline Outros pescados em filé fresco & 0,1 & 0,0 & - & - & 0,2 & - & 0,2 & - & 0,2 \\
\hline Outros pescados frescos & 0,4 & 0,1 & 0,0 & - & - & 0,9 & 3,9 & - & 0,3 \\
\hline Outros pescados salgados & 0,0 & - & - & - & - & - & 0,3 & - & - \\
\hline Pescados não especificados & 0,6 & 0,3 & 0,4 & 0,7 & - & 0,1 & 0,8 & 0,3 & 0,6 \\
\hline Peixe em filé congelado & 0,0 & - & 0,0 & 0,2 & - & - & 0,1 & - & - \\
\hline Peixe em filé fresco & 0,0 & - & - & 0,1 & - & - & - & - & - \\
\hline Peixe fresco & 0,5 & 0,3 & 0,3 & 0,4 & - & 0,1 & 0,7 & 0,3 & 0,7 \\
\hline Peixe salgado & 0,0 & - & 0,1 & - & - & - & 0,0 & - & - \\
\hline Aves e ovos & 16,4 & 11,3 & 15,9 & 19,6 & 15,2 & 14,6 & 30,4 & 15,7 & 0,7 \\
\hline Aves & 13,2 & 8,8 & 13,8 & 16,2 & 12,4 & 12,3 & 26,1 & 12,5 & 0,7 \\
\hline As a de frango & 0,5 & 0,4 & 1,2 & 1,4 & 0,9 & 1,4 & 0,0 & 0,1 & 0,8 \\
\hline Carne de frango não especificada & 1,0 & 0,6 & 1,0 & 0,8 & 0,6 & 0,5 & 0,5 & 0,4 & 0,7 \\
\hline Coxa de frango & 1,6 & 1,4 & 0,9 & 3,1 & 5,6 & 1,5 & 1,6 & 2,6 & 0,9 \\
\hline Dorso de frango & 0,1 & 0,0 & - & 0,5 & - & 0,1 & - & 0,1 & 0,1 \\
\hline Frango abatido (inteiro) & 7,8 & 3,9 & 5,7 & 3,1 & 2,7 & 6,7 & 23,0 & 7,1 & 0,5 \\
\hline Frango vivo & 0,2 & 0,0 & - & 0,1 & 0,6 & - & - & - & 0,1 \\
\hline Miúdos de frango & 0,2 & 0,1 & 0,1 & 0,6 & 0,4 & - & 0,1 & 0,1 & 0,9 \\
\hline Peito de frango & 1,5 & 1,8 & 4,0 & 5,5 & 1,2 & 1,9 & 0,9 & 2,0 & 1,2 \\
\hline Outras carnes de frango & 0,2 & 0,2 & 0,2 & 0,7 & 0,2 & 0,1 & 0,1 & 0,0 & 1,0 \\
\hline Pato inteiro ou em cortes & 0,0 & - & - & - & - & - & - & - & - \\
\hline
\end{tabular}


Tabela 21 (cont.): Aquisição alimentar domiciliar anual - Brasil e Capitais

\begin{tabular}{|c|c|c|c|c|c|c|c|c|c|}
\hline Produtos & Brasil & $\begin{array}{c}\text { São } \\
\text { Paulo }\end{array}$ & \begin{tabular}{c|} 
Belo \\
Horizonte
\end{tabular} & $\begin{array}{c}\text { Rio de } \\
\text { Janeiro }\end{array}$ & $\begin{array}{c}\text { Porto } \\
\text { Alegre }\end{array}$ & Cuiabá & Manaus & Salvador & $\begin{array}{c}\text { SP/ } \\
\text { Brasil }\end{array}$ \\
\hline Peru abatido & 0,0 & 0,1 & 0,1 & 0,1 & - & - & - & - & 2,2 \\
\hline Peru em cortes & 0,1 & 0,2 & 0,6 & 0,3 & 0,1 & 0,0 & 0,0 & 0,2 & 2,3 \\
\hline Outras & 0,4 & 0,0 & - & 0,0 & - & 0,0 & - & 0,0 & 0,1 \\
\hline Ovos & 3,2 & 2,5 & 2,2 & 3,4 & 2,8 & 2,4 & 4,4 & 3,1 & 0,8 \\
\hline Ovo de galinha & 3,2 & 2,5 & 2,2 & 3,3 & 2,7 & 2,4 & 4,3 & 3,0 & 0,8 \\
\hline Outros & 0,1 & 0,0 & 0,0 & 0,0 & 0,0 & 0,0 & 0,0 & 0,1 & 0,2 \\
\hline Laticínios & 43,7 & 48,8 & 58,6 & 47,4 & 68,9 & 48,9 & 16,7 & 25,4 & 1,1 \\
\hline Leite e creme de leite & 38,4 & 42,7 & 48,7 & 38,9 & 58,7 & 42,8 & 12,3 & 19,2 & 1,1 \\
\hline Creme de leite & 0,4 & 0,4 & 0,5 & 0,6 & 0,5 & 0,5 & 0,3 & 0,2 & 1,1 \\
\hline Leite condensado & 0,7 & 0,7 & 1,3 & 1,3 & 0,8 & 0,8 & 0,7 & 0,9 & 1,1 \\
\hline Leite de vaca fresco & 9,8 & - & 0,5 & 0,0 & 0,6 & 0,6 & 0,1 & 1,5 & - \\
\hline Leite de vaca pasteurizado & 25,6 & 39,2 & 43,9 & 31,3 & 53,3 & 39,8 & 7,4 & 13,8 & 1,5 \\
\hline Leite em pó desengordurado & 0,1 & 0,1 & 0,0 & 0,4 & 0,1 & 0,1 & 0,2 & 0,2 & 0,6 \\
\hline Leite em pó integral & 0,8 & 0,6 & 0,1 & 1,3 & 0,5 & 0,3 & 2,3 & 2,1 & 0,7 \\
\hline Leite em pó não especificado & 0,1 & 0,0 & 0,0 & 0,1 & - & 0,1 & 0,4 & 0,2 & 0,1 \\
\hline Outros & 0,1 & 1,7 & 2,2 & 4,1 & 3,0 & 0,7 & 0,9 & 0,3 & 15,0 \\
\hline Queijos e requeijão & 2,2 & 2,6 & 4,2 & 4,8 & 3,9 & 1,6 & 1,4 & 2,0 & 1,2 \\
\hline Queijo minas & 0,7 & 0,6 & 1,6 & 1,9 & 0,0 & 0,1 & 0,2 & 0,2 & 0,9 \\
\hline Queijo mozzarella & 0,7 & 1,1 & 1,2 & 0,9 & 1,3 & 1,0 & 0,3 & 0,6 & 1,6 \\
\hline Queijo não especificado & 0,1 & 0,1 & 0,3 & 0,1 & 0,1 & 0,0 & 0,1 & 0,1 & 0,7 \\
\hline Queijo parmezão & 0,1 & 0,2 & 0,1 & 0,1 & 0,1 & 0,0 & 0,0 & 0,1 & 2,6 \\
\hline Queijo prato & 0,3 & 0,2 & 0,1 & 0,8 & 1,8 & 0,3 & 0,7 & 0,7 & 0,6 \\
\hline Outros queijos & 0,1 & 0,1 & 0,4 & 0,3 & 0,2 & 0,0 & 0,1 & 0,1 & 1,3 \\
\hline Requeijão & 0,2 & 0,4 & 0,6 & 0,6 & 0,3 & 0,2 & 0,1 & 0,2 & 1,8 \\
\hline Outros laticínios & 3,1 & 3,5 & 5,7 & 3,7 & 6,3 & 4,5 & 3,0 & 4,2 & 1,1 \\
\hline logurte & 2,1 & 2,2 & 3,7 & 2,4 & 3,4 & 2,7 & 2,3 & 2,5 & 1,1 \\
\hline Leite fermentado & 0,7 & 0,9 & 1,2 & 0,8 & 2,6 & 1,6 & - & 1,1 & 1,3 \\
\hline Manteiga & 0,3 & 0,3 & 0,7 & 0,4 & 0,2 & 0,2 & 0,7 & 0,5 & 1,2 \\
\hline Outros & 0,1 & 0,0 & 0,1 & 0,1 & 0,1 & - & - & - & 0,2 \\
\hline Açúcares, doces e confeitaria & 20,5 & 14,9 & 14,5 & 16,4 & 14,8 & 14,9 & 16,4 & 13,6 & 0,7 \\
\hline Açúcares & 17,0 & 11,4 & 9,5 & 11,6 & 8,6 & 12,3 & 14,3 & 10,2 & 0,7 \\
\hline Açúcar cristal & 8,0 & 6,7 & 8,9 & 2,4 & 6,9 & 12,1 & 9,3 & 9,4 & 0,8 \\
\hline Açúcar demerara & 0,2 & 0,4 & 0,0 & 1,0 & 0,1 & - & 0,2 & 0,3 & 2,5 \\
\hline Açúcar não especificado & 5,5 & 0,1 & - & 4,6 & - & - & 4,0 & - & 0,0 \\
\hline Açúcar refinado & 3,2 & 4,1 & 0,6 & 3,4 & 1,6 & 0,2 & 0,6 & 0,5 & 1,3 \\
\hline Outros & 0,1 & 0,0 & 0,1 & 0,1 & 0,0 & 0,0 & 0,1 & 0,1 & 0,3 \\
\hline Doces e produtos de confeitaria & 2,6 & 2,7 & 3,9 & 3,6 & 4,3 & 1,9 & 1,1 & 2,0 & 1,0 \\
\hline Bombom & 0,2 & 0,3 & 0,2 & 0,4 & 0,3 & 0,1 & 0,1 & 0,0 & 1,7 \\
\hline Chocolate em tablete & 0,2 & 0,2 & 0,2 & 0,2 & 0,6 & 0,1 & 0,1 & 0,2 & 1,1 \\
\hline Doce a base de leite & 0,2 & 0,1 & 0,2 & 0,1 & 0,5 & 0,2 & 0,0 & 0,1 & 0,4 \\
\hline Doce de fruta cristalizado & 0,0 & - & 0,0 & - & 0,0 & 0,1 & - & - & - \\
\hline Doce de fruta em calda & 0,1 & 0,0 & 0,2 & 0,1 & 0,2 & 0,1 & 0,0 & 0,1 & 0,5 \\
\hline Doce de fruta em pasta & 0,3 & 0,1 & 0,3 & 0,4 & 0,2 & 0,2 & 0,1 & 0,1 & 0,3 \\
\hline Rapadura & 0,1 & 0,0 & 0,0 & - & 0,1 & - & - & - & 0,1 \\
\hline Sorvete & 0,7 & 1,4 & 1,9 & 1,6 & 1,1 & 0,6 & 0,6 & 0,5 & 2,1 \\
\hline Outros & 0,1 & 0,5 & 0,8 & 0,9 & 1,2 & 0,5 & 0,1 & 1,0 & 4,4 \\
\hline Outros açúcares, doces, confeitaria & 1,0 & 0,8 & 1,1 & 1,2 & 1,9 & 0,7 & 1,1 & 1,4 & 0,9 \\
\hline Chocolate em pó & 0,7 & 0,7 & 0,8 & 0,9 & 1,5 & 0,5 & 0,6 & 0,7 & 1,1 \\
\hline Gelatina & 0,1 & 0,1 & 0,2 & 0,1 & 0,2 & 0,1 & 0,0 & 0,0 & 0,8 \\
\hline Mel de abelha & 0,0 & - & 0,1 & 0,1 & 0,2 & 0,0 & - & 0,0 & - \\
\hline Polpa de fruta & 0,1 & 0,0 & 0,1 & 0,1 & 0,1 & 0,1 & 0,4 & 0,7 & 0,3 \\
\hline Outros & 0,1 & - & 0,0 & 0,0 & 0,0 & - & - & 0,0 & - \\
\hline Sais e condimentos & 5,4 & 5,3 & 4,3 & 5,7 & 4,3 & 4,8 & 3,5 & 4,3 & 1,0 \\
\hline Sais & 2,5 & 1,0 & 0,9 & 1,8 & 1,0 & 2,0 & 1,6 & 1,3 & 0,4 \\
\hline Sal grosso & 0,4 & 0,0 & 0,1 & 0,0 & 0,3 & 0,3 & 0,0 & 0,4 & 0,0 \\
\hline Sal refinado & 2,1 & 1,0 & 0,8 & 1,8 & 0,7 & 1,7 & 1,6 & 0,9 & 0,5 \\
\hline Outros & 0,1 & 0,0 & 0,0 & - & - & - & - & - & 0,0 \\
\hline Condimentos & 3,0 & 4,3 & 3,3 & 3,8 & 3,3 & 2,9 & 1,9 & 3,0 & 1,5 \\
\hline Caldo de carne em tablete & 0,0 & 0,1 & 0,0 & 0,0 & 0,0 & 0,1 & 0,0 & 0,0 & 2,2 \\
\hline Caldo de galinha em tablete & 0,0 & 0,0 & 0,1 & 0,1 & 0,1 & 0,0 & 0,0 & 0,1 & 0,7 \\
\hline Outros caldos em tablete & 0,0 & 0,0 & 0,1 & 0,0 & 0,1 & 0,0 & 0,0 & 0,1 & 0,7 \\
\hline Colorau & 0,1 & 0,0 & 0,0 & 0,0 & - & - & 0,2 & 0,0 & 0,1 \\
\hline Fermento & 0,1 & 0,0 & 0,0 & 0,0 & 0,0 & 0,1 & 0,0 & 0,0 & 0,7 \\
\hline Leite de coco & 0,1 & 0,1 & 0,0 & 0,1 & 0,0 & 0,0 & 0,2 & 0,4 & 1,7 \\
\hline Maionese & 0,4 & 0,5 & 0,5 & 0,6 & 0,7 & 0,5 & 0,2 & 0,3 & 1,4 \\
\hline Massa de tomate & 0,7 & 0,6 & 0,7 & 1,0 & 0,8 & 0,8 & 0,4 & 0,8 & 1,0 \\
\hline
\end{tabular}


Tabela 21 (cont.): Aquisição alimentar domiciliar anual - Brasil e Capitais

\begin{tabular}{|c|c|c|c|c|c|c|c|c|c|}
\hline Produtos & Brasil & $\begin{array}{l}\text { São } \\
\text { Paulo }\end{array}$ & \begin{tabular}{|c|} 
Belo \\
Horizonte
\end{tabular} & $\begin{array}{l}\text { Rio de } \\
\text { Janeiro }\end{array}$ & $\begin{array}{l}\text { Porto } \\
\text { Alegre }\end{array}$ & Cuiabá & Manaus & Salvador & $\begin{array}{c}\text { SP/ } \\
\text { Brasil }\end{array}$ \\
\hline Molho de tomate & 0,6 & 1,9 & 1,2 & 1,0 & 0,6 & 0,4 & 0,2 & 0,6 & 3,0 \\
\hline Tempero misto & 0,1 & 0,2 & 0,2 & 0,1 & 0,2 & 0,2 & 0,0 & 0,1 & 1,5 \\
\hline Vinagre de álcool & 0,2 & 0,0 & 0,1 & - & 0,2 & 0,2 & 0,1 & 0,3 & 0,1 \\
\hline Vinagre de vinho & 0,1 & 0,1 & 0,0 & 0,4 & 0,1 & 0,1 & 0,2 & 0,0 & 1,2 \\
\hline Vinagre não especificado & 0,2 & 0,4 & 0,1 & 0,3 & 0,1 & 0,1 & 0,2 & 0,1 & 2,1 \\
\hline Outros & 0,1 & 0,2 & 0,3 & 0,3 & 0,3 & 0,3 & 0,2 & 0,2 & 1,9 \\
\hline Óleos e Gorduras & 8,9 & 8,1 & 8,2 & 7,6 & 7,6 & 9,8 & 7,5 & 5,4 & 0,9 \\
\hline Óleos & 7,1 & 6,1 & 6,8 & 5,2 & 5,9 & 8,6 & 5,7 & 3,7 & 0,9 \\
\hline Azeite de oliva & 0,2 & 0,4 & 0,4 & 0,7 & 0,2 & 0,2 & 0,1 & 0,4 & 2,3 \\
\hline Óleo de girassol & 0,1 & 0,1 & 0,3 & 0,1 & 0,2 & 0,2 & 0,1 & 0,1 & 0,8 \\
\hline Óleo de canola & 0,1 & 0,2 & 0,2 & 0,2 & 0,2 & - & - & 0,0 & 3,2 \\
\hline Óleo de milho & 0,1 & 0,4 & 0,8 & - & 0,2 & 0,0 & 0,0 & 0,0 & 3,5 \\
\hline Óleo de soja & 6,3 & 4,8 & 5,0 & 4,2 & 4,1 & 8,2 & 5,2 & 2,3 & 0,8 \\
\hline Óleo não especificado & 0,1 & 0,1 & 0,1 & 0,0 & - & - & 0,1 & 0,6 & 0,9 \\
\hline Outros & 0,1 & 0,0 & - & - & 1,1 & 0,0 & 0,0 & 0,2 & 0,3 \\
\hline Gorduras & 1,8 & 2,1 & 1,4 & 2,4 & 1,7 & 1,2 & 1,9 & 1,8 & 1,1 \\
\hline Banha de porco & 0,1 & 0,0 & - & - & - & 0,1 & - & - & 0,1 \\
\hline Margarina vegetal & 1,7 & 2,0 & 1,4 & 2,4 & 1,7 & 1,1 & 1,9 & 1,8 & 1,2 \\
\hline Outras & 0,4 & 0,0 & 0,0 & - & - & 0,0 & - & - & 0,0 \\
\hline Alimentos preparados e misturas & 3,5 & 5,3 & 5,4 & 3,2 & 6,9 & 5,2 & 3,7 & 1,6 & 1,5 \\
\hline Alimentos preparados & 3,2 & 5,0 & 5,0 & 2,9 & 6,5 & 4,8 & 3,6 & 1,1 & 1,6 \\
\hline Alimento congelado & 0,1 & 0,2 & 0,3 & 0,2 & 0,2 & 0,0 & 0,0 & 0,0 & 2,3 \\
\hline Batata frita & 0,1 & 0,2 & 0,4 & 0,3 & 0,3 & 0,1 & 0,0 & 0,0 & 1,7 \\
\hline Carne-assada & 0,1 & 0,1 & 0,1 & 0,0 & 0,1 & 0,3 & 0,1 & 0,0 & 1,0 \\
\hline Frango assado ou defumado & 0,7 & 1,3 & 1,0 & 0,9 & 0,9 & 1,2 & 1,1 & 0,3 & 1,8 \\
\hline Frango empanado & 0,2 & 0,1 & 0,1 & 0,2 & 0,6 & 0,2 & 0,4 & 0,1 & 0,9 \\
\hline Massa & 0,5 & 1,2 & 1,5 & 0,2 & 1,9 & 0,9 & 0,3 & 0,3 & 2,3 \\
\hline Refeição & 0,7 & 0,6 & 0,9 & 0,4 & 0,6 & 1,8 & 0,6 & 0,1 & 0,9 \\
\hline Salgadinho & 0,3 & 0,7 & 0,2 & 0,1 & 0,7 & 0,1 & 0,2 & 0,1 & 2,6 \\
\hline Sanduíche & 0,1 & 0,3 & 0,2 & 0,1 & 0,2 & - & 0,0 & 0,0 & 3,2 \\
\hline Outros & 0,1 & 0,3 & 0,5 & 0,7 & 1,0 & 0,2 & 0,8 & 0,1 & 2,6 \\
\hline Misturas industriais & 0,3 & 0,3 & 0,4 & 0,2 & 0,3 & 0,3 & 0,1 & 0,5 & 1,0 \\
\hline Mistura para bolo & 0,3 & 0,3 & 0,4 & 0,2 & 0,2 & 0,3 & 0,1 & 0,5 & 1,1 \\
\hline Outras & 0,4 & 0,0 & 0,0 & 0,0 & 0,1 & 0,1 & 0,0 & 0,0 & 0,0 \\
\hline Outros produtos & 0,0 & 0,0 & 0,0 & 0,0 & 0,0 & 0,0 & 0,0 & 0,0 & 0,0 \\
\hline SUBTOTAL & 264,5 & 240,3 & 264,0 & 271,5 & 286,4 & 256,9 & 248,0 & 208,7 & 0,9 \\
\hline Bebidas e infusões & 50,7 & 55,5 & 57,0 & 63,7 & 80,1 & 53,1 & 62,4 & 45,8 & 1,1 \\
\hline Bebidas alcoólicas & 6,8 & 6,2 & 11,8 & 16,1 & 9,8 & 10,1 & 3,9 & 6,9 & 0,9 \\
\hline Aguardente de cana & 0,2 & 0,1 & 0,1 & 0,4 & 0,1 & 0,1 & 0,1 & 0,1 & 0,4 \\
\hline Outras aguardentes & 0,0 & - & - & - & - & - & 0,1 & - & - \\
\hline Cerveja & 5,6 & 5,3 & 10,7 & 10,4 & 7,4 & 8,4 & 3,4 & 5,9 & 0,9 \\
\hline Vinho & 0,7 & 0,6 & 1,0 & 4,1 & 2,0 & 1,1 & 0,3 & 0,6 & 0,9 \\
\hline Outras & 0,4 & 0,2 & 0,1 & 1,2 & 0,3 & 0,5 & 0,1 & 0,3 & 0,5 \\
\hline Bebidas não alcoólicas & 40,8 & 46,3 & 42,2 & 45,0 & 66,3 & 40,7 & 56,0 & 37,1 & 1,1 \\
\hline Água mineral & 14,0 & 10,4 & 4,1 & 6,6 & 11,5 & 10,5 & 22,9 & 18,8 & 0,7 \\
\hline Refrigerante de cola & 12,7 & 18,0 & 15,3 & 18,8 & 30,0 & 16,0 & 9,0 & 6,5 & 1,4 \\
\hline Refrigerante de guaraná & 5,7 & 5,1 & 7,2 & 6,7 & 13,4 & 4,8 & 7,6 & 2,9 & 0,9 \\
\hline Refrigerante de laranja & 1,5 & 1,0 & 0,9 & 0,4 & 1,3 & 1,7 & 0,9 & 0,9 & 0,7 \\
\hline Refrigerante de limão & 0,8 & 2,1 & 0,5 & 0,9 & 1,7 & 1,7 & 0,3 & 1,5 & 2,7 \\
\hline Refrigerante de maçã & 0,1 & 0,1 & - & - & - & - & 0,1 & - & 0,9 \\
\hline Refrigerante de uva & 0,5 & 0,4 & 0,9 & 0,5 & 0,3 & 0,5 & 1,5 & 0,2 & 0,9 \\
\hline Bebida energética & 0,1 & 0,2 & 0,3 & 0,0 & 0,2 & 0,1 & 0,0 & 0,1 & 2,6 \\
\hline Refrigerante não especificado & 2,7 & 3,0 & 4,5 & 4,5 & 1,6 & 2,5 & 9,6 & 4,1 & 1,1 \\
\hline Outros refrigerantes & 0,6 & 0,7 & 1,3 & 1,0 & 0,1 & 0,1 & 0,5 & - & 1,3 \\
\hline Suco de fruta em pó & 0,4 & 0,4 & 0,5 & 0,1 & 0,6 & 0,7 & 0,4 & 0,2 & 1,0 \\
\hline Suco de fruta envasado & 1,5 & 4,4 & 6,4 & 3,5 & 3,7 & 1,9 & 3,2 & 1,9 & 3,0 \\
\hline Outras & 0,4 & 0,5 & 0,1 & 2,0 & 1,9 & 0,2 & 0,1 & 0,1 & 1,2 \\
\hline Cafés & 2,6 & 2,9 & 3,0 & 2,4 & 1,9 & 1,9 & 2,4 & 1,7 & 1,1 \\
\hline Café moído & 2,4 & 2,7 & 2,8 & 2,3 & 1,6 & 1,9 & 2,3 & 1,5 & 1,1 \\
\hline Café solúvel & 0,1 & 0,2 & 0,1 & 0,0 & 0,2 & 0,0 & 0,1 & 0,2 & 1,0 \\
\hline Outros & 0,1 & 0,0 & 0,0 & 0,1 & 0,1 & 0,0 & 0,0 & 0,0 & 0,1 \\
\hline Chás & 0,5 & 0,1 & 0,1 & 0,2 & 2,1 & 0,3 & 0,0 & 0,1 & 0,2 \\
\hline Chá-mate & 0,5 & 0,1 & 0,0 & 0,2 & 1,8 & 0,3 & - & 0,0 & 0,2 \\
\hline Outros & 0,1 & 0,0 & 0,0 & 0,0 & 0,2 & 0,0 & 0,0 & 0,1 & 0,1 \\
\hline TOTAL & 315,2 & 295,8 & 321,0 & 335,2 & 366,5 & 309,9 & 310,4 & 254,6 & 0,9 \\
\hline
\end{tabular}

Fonte: IBGE, Diretoria de Pesquisas, Coordenação de Trabalho e Rendimento, Pesquisa de Orçamentos Familiares 2008-2009.

Nota: As quantidades de produtos adquiridos na forma líquida foram transformadas em kg, considerando-se volume igual a peso. 
ANEXO C

Tabela 22: Aquisição Alimentar Domiciliar Anual por Classe de Rendimento

\begin{tabular}{|c|c|c|c|c|c|c|c|c|c|}
\hline \multirow[b]{2}{*}{ Produtos } & \multirow[b]{2}{*}{ Total } & \multicolumn{6}{|c|}{ Classes de rendimento (Salários-Mínimos) } & \multirow{2}{*}{$\begin{array}{c}>15 \mathrm{SM} / \\
\text { Brasil }\end{array}$} & \multirow{2}{*}{$\begin{array}{l}>15 \mathrm{SM} / \\
\text { Até } 2 \mathrm{SM}\end{array}$} \\
\hline & & Até 2 (1) & De 2 a 3 & De 3 a 6 & De 6 a 10 & De 10 a 15 & Mais de 15 & & \\
\hline Cereais e leguminosas & 39,0 & 40,9 & 41,7 & 41,2 & 36,3 & 35,6 & 30,0 & 0,77 & 0,73 \\
\hline Cereais & 29,4 & 30,3 & 31,2 & 30,9 & 28,4 & 28,7 & 21,8 & 0,74 & 0,72 \\
\hline Arroz não especificado & 11,9 & 14,3 & 12,7 & 11,8 & 10,2 & 13,8 & 6,7 & 0,56 & 0,47 \\
\hline Arroz polido & 14,6 & 13,3 & 16,0 & 15,7 & 15,7 & 11,9 & 11,9 & 0,81 & 0,89 \\
\hline Milho em grão & 2,1 & 2,2 & 2,0 & 2,7 & 1,4 & 1,6 & 2,1 & 0,97 & 0,93 \\
\hline Milho verde em conserva & 0,2 & 0,0 & 0,1 & 0,2 & 0,3 & 0,3 & 0,3 & 1,85 & 7,15 \\
\hline Milho verde em espiga & 0,5 & 0,3 & 0,4 & 0,4 & 0,7 & 1,0 & 0,6 & 1,27 & 2,42 \\
\hline Outros & 0,1 & 0,1 & 0,1 & 0,1 & 0,1 & 0,1 & 0,2 & 1,48 & 1,32 \\
\hline Leguminosas & 9,6 & 10,6 & 10,4 & 10,3 & 7,9 & 6,9 & 8,2 & 0,86 & 0,78 \\
\hline Feijão-fradinho & 1,2 & 2,1 & 1,8 & 1,0 & 0,4 & 0,4 & 0,4 & 0,32 & 0,18 \\
\hline Feijão-jalo & 0,1 & 0,2 & 0,2 & 0,1 & 0,1 & 0,1 & 0,1 & 0,66 & 0,54 \\
\hline Feijão-manteiga & 0,3 & 0,3 & 0,3 & 0,3 & 0,2 & 0,1 & 0,2 & 0,70 & 0,52 \\
\hline Feijão-mulatinho & 0,6 & 0,8 & 0,8 & 0,4 & 0,4 & 0,2 & 0,3 & 0,57 & 0,38 \\
\hline Feijão-preto & 2,0 & 1,8 & 1,9 & 2,2 & 1,9 & 1,8 & 2,6 & 1,30 & 1,47 \\
\hline Feijão-rajado & 3,9 & 3,8 & 4,0 & 4,4 & 3,6 & 3,2 & 3,1 & 0,81 & 0,83 \\
\hline Feijão-roxo & 0,0 & 0,0 & 0,0 & 0,0 & 0,0 & 0,0 & 0,0 & 0,81 & 1,13 \\
\hline Outros feijões & 1,1 & 1,3 & 1,1 & 1,3 & 0,8 & 0,5 & 0,6 & 0,56 & 0,46 \\
\hline Outras & 0,4 & 0,3 & 0,4 & 0,4 & 0,4 & 0,5 & 0,9 & 2,06 & 3,15 \\
\hline Hortaliças & 27,1 & 15,4 & 22,6 & 27,1 & 32,6 & 35,1 & 44,3 & 1,64 & 2,87 \\
\hline Hortaliças folhosas e florais & 3,2 & 1,4 & 2,5 & 3,1 & 4,2 & 4,6 & 6,0 & 1,87 & 4,18 \\
\hline Acelga & 0,0 & 0,0 & 0,0 & 0,0 & 0,1 & 0,0 & 0,1 & 2,84 & 15,00 \\
\hline Agrião & 0,1 & 0,0 & 0,0 & 0,1 & 0,1 & 0,1 & 0,2 & 3,46 & 20,75 \\
\hline Alface & 0,9 & 0,4 & 0,7 & 0,9 & 1,1 & 1,2 & 1,6 & 1,77 & 3,93 \\
\hline Cheiro-verde & 0,2 & 0,2 & 0,2 & 0,2 & 0,2 & 0,2 & 0,3 & 1,29 & 1,61 \\
\hline Couve & 0,3 & 0,2 & 0,3 & 0,4 & 0,4 & 0,4 & 0,5 & 1,60 & 3,33 \\
\hline Couve-brócolis & 0,1 & 0,0 & 0,0 & 0,1 & 0,2 & 0,3 & 0,7 & 4,41 & 50,23 \\
\hline Couve-flor & 0,2 & 0,0 & 0,1 & 0,1 & 0,2 & 0,3 & 0,5 & 3,35 & 15,14 \\
\hline Repolho & 1,0 & 0,5 & 0,9 & 1,0 & 1,4 & 1,6 & 1,3 & 1,28 & 2,56 \\
\hline Outras & 0,3 & 0,1 & 0,2 & 0,3 & 0,5 & 0,5 & 0,8 & 2,32 & 6,28 \\
\hline Hortaliças frutosas & 12,6 & 7,6 & 10,8 & 12,4 & 14,6 & 15,8 & 21,4 & 1,70 & 2,82 \\
\hline Abóbora & 1,2 & 0,8 & 1,1 & 1,3 & 1,2 & 1,6 & 1,6 & 1,31 & 1,94 \\
\hline Abobrinha & 0,4 & 0,1 & 0,2 & 0,4 & 0,4 & 0,6 & 0,9 & 2,33 & 9,77 \\
\hline Azeitona em conserva & 0,1 & 0,0 & 0,0 & 0,1 & 0,2 & 0,2 & 0,4 & 3,18 & 22,06 \\
\hline Berinjela & 0,2 & 0,0 & 0,1 & 0,1 & 0,2 & 0,3 & 0,6 & 3,46 & 19,47 \\
\hline Cebola & 3,2 & 2,1 & 2,9 & 3,2 & 3,6 & 3,8 & 5,1 & 1,59 & 2,40 \\
\hline Chuchu & 0,8 & 0,4 & 0,7 & 0,7 & 1,0 & 1,0 & 1,4 & 1,76 & 3,35 \\
\hline Jiló & 0,1 & 0,1 & 0,1 & 0,2 & 0,2 & 0,2 & 0,2 & 1,24 & 2,18 \\
\hline Maxixe & 0,1 & 0,1 & 0,1 & 0,1 & 0,1 & 0,1 & 0,1 & 1,03 & 1,30 \\
\hline Pepino fresco & 0,5 & 0,2 & 0,4 & 0,5 & 0,6 & 0,6 & 0,8 & 1,74 & 4,32 \\
\hline Pimentão & 0,6 & 0,4 & 0,6 & 0,6 & 0,6 & 0,7 & 1,0 & 1,78 & 2,97 \\
\hline Quiabo & 0,3 & 0,2 & 0,2 & 0,3 & 0,3 & 0,3 & 0,4 & 1,52 & 2,21 \\
\hline Tomate & 4,9 & 3,2 & 4,3 & 4,7 & 5,8 & 6,0 & 8,2 & 1,67 & 2,60 \\
\hline Vagem & 0,2 & 0,1 & 0,1 & 0,1 & 0,2 & 0,2 & 0,5 & 3,21 & 9,46 \\
\hline Outras & 0,1 & 0,0 & 0,1 & 0,1 & 0,2 & 0,2 & 0,3 & 2,75 & 8,03 \\
\hline Hortaliças tuberosas e outras & 11,3 & 6,4 & 9,4 & 11,6 & 13,8 & 14,7 & 16,8 & 1,49 & 2,64 \\
\hline Alho & 0,5 & 0,3 & 0,4 & 0,5 & 0,6 & 0,6 & 0,7 & 1,38 & 2,10 \\
\hline Batata-aipo & 0,1 & 0,0 & 0,0 & 0,1 & 0,1 & 0,2 & 0,2 & 2,61 & 69,67 \\
\hline Batata-baroa & 0,1 & 0,0 & 0,0 & 0,0 & 0,1 & 0,2 & 0,2 & 2,71 & 9,00 \\
\hline Batata-doce & 0,6 & 0,6 & 0,6 & 0,7 & 0,6 & 0,6 & 0,7 & 1,13 & 1,30 \\
\hline Batata-inglesa & 4,0 & 2,2 & 3,3 & 4,2 & 5,1 & 5,8 & 5,6 & 1,38 & 2,59 \\
\hline Batata não especificada & 1,6 & 0,7 & 1,2 & 1,5 & 2,2 & 1,8 & 2,9 & 1,87 & 4,38 \\
\hline Beterraba & 0,5 & 0,2 & 0,3 & 0,5 & 0,7 & 0,8 & 0,8 & 1,69 & 3,37 \\
\hline Cará & 0,1 & 0,0 & 0,1 & 0,1 & 0,1 & 0,1 & 0,1 & 1,78 & 3,12 \\
\hline Cenoura & 1,6 & 0,8 & 1,2 & 1,5 & 2,1 & 2,2 & 2,6 & 1,67 & 3,23 \\
\hline Inhame & 0,4 & 0,2 & 0,4 & 0,4 & 0,4 & 0,5 & 0,5 & 1,40 & 2,09 \\
\hline Mandioca & 1,8 & 1,3 & 1,7 & 2,1 & 1,8 & 1,7 & 2,0 & 1,11 & 1,51 \\
\hline Outras & 0,1 & 0,0 & 0,1 & 0,1 & 0,2 & 0,3 & 0,5 & 3,59 & 16,00 \\
\hline Frutas & 28,9 & 14,3 & 20,4 & 27,2 & 35,8 & 41,1 & 59,3 & 2,05 & 4,16 \\
\hline Frutas de clima tropical & 24,8 & 12,9 & 18,2 & 23,6 & 30,4 & 34,6 & 49,4 & 1,99 & 3,83 \\
\hline Abacate & 0,3 & 0,1 & 0,2 & 0,3 & 0,4 & 0,4 & 0,6 & 2,06 & 4,77 \\
\hline Abacaxi & 1,5 & 0,6 & 1,0 & 1,4 & 1,9 & 1,9 & 3,3 & 2,22 & 5,26 \\
\hline Acerola & 0,1 & 0,1 & 0,1 & 0,1 & 0,2 & 0,1 & 0,2 & 1,26 & 1,73 \\
\hline
\end{tabular}


Tabela 22 (cont.): Aquisição alimentar domiciliar anual por classe de rendimento

\begin{tabular}{|c|c|c|c|c|c|c|c|c|c|}
\hline \multirow[b]{2}{*}{ Produtos } & \multirow[b]{2}{*}{ Total } & \multicolumn{6}{|c|}{ Classes de rendimento (Salários-Mínimos) } & \multirow{2}{*}{$\begin{array}{c}>15 \mathrm{SM} / \\
\text { Brasil }\end{array}$} & \multirow{2}{*}{$\begin{array}{l}>15 \mathrm{SM} / \\
\text { Até } 2 \mathrm{SM}\end{array}$} \\
\hline & & Até $2^{(1)}$ & De 2 a 3 & De 3 a 6 & De 6 a 10 & De 10 a 15 & Mais de 15 & & \\
\hline Banana-d'água & 2,2 & 0,7 & 1,7 & 2,2 & 3,2 & 3,1 & 4,0 & 1,80 & 5,37 \\
\hline Banana-da-terra & 0,4 & 0,5 & 0,4 & 0,4 & 0,4 & 0,5 & 0,6 & 1,31 & 1,21 \\
\hline Banana-maçã & 0,3 & 0,2 & 0,2 & 0,3 & 0,4 & 0,4 & 0,4 & 1,41 & 2,34 \\
\hline Banana-ouro & 0,0 & 0,0 & 0,0 & 0,0 & 0,0 & 0,0 & 0,0 & 4,60 & 11,50 \\
\hline Banana-prata & 2,8 & 2,2 & 2,3 & 2,6 & 3,1 & 3,3 & 4,4 & 1,58 & 2,01 \\
\hline Outras bananas & 1,9 & 1,6 & 1,7 & 2,0 & 2,2 & 2,2 & 2,2 & 1,13 & 1,35 \\
\hline Goiaba & 0,4 & 0,2 & 0,3 & 0,4 & 0,4 & 0,5 & 0,7 & 1,78 & 2,73 \\
\hline Laranja-baía & 0,2 & 0,1 & 0,1 & 0,1 & 0,4 & 0,3 & 0,4 & 1,97 & 4,25 \\
\hline Laranja-lima & 0,4 & 0,1 & 0,2 & 0,4 & 0,4 & 0,7 & 1,0 & 2,62 & 9,76 \\
\hline Laranja-pera & 2,8 & 1,1 & 1,7 & 2,6 & 3,6 & 4,3 & 6,5 & 2,33 & 5,92 \\
\hline Laranja-seleta & 0,1 & 0,1 & 0,0 & 0,1 & 0,1 & 0,1 & 0,2 & 2,34 & 3,87 \\
\hline Outras Iaranjas & 2,0 & 1,1 & 1,7 & 1,9 & 2,7 & 2,4 & 3,1 & 1,56 & 2,90 \\
\hline Limão comum & 0,6 & 0,2 & 0,3 & 0,5 & 0,8 & 1,0 & 1,6 & 2,66 & 8,17 \\
\hline Mamão & 2,0 & 0,5 & 0,9 & 1,7 & 2,5 & 3,7 & 6,6 & 3,22 & 12,95 \\
\hline Manga & 1,0 & 0,5 & 0,7 & 0,9 & 1,3 & 1,3 & 2,1 & 2,14 & 4,24 \\
\hline Maracujá & 0,3 & 0,2 & 0,3 & 0,3 & 0,4 & 0,5 & 0,7 & 1,92 & 3,09 \\
\hline Melancia & 3,4 & 1,9 & 2,8 & 3,3 & 3,7 & 4,5 & 6,3 & 1,88 & 3,29 \\
\hline Melão & 0,5 & 0,1 & 0,3 & 0,3 & 0,6 & 0,8 & 1,5 & 3,14 & 16,35 \\
\hline Tangerina & 1,2 & 0,4 & 0,6 & 1,3 & 1,4 & 1,9 & 2,5 & 2,13 & 5,85 \\
\hline Outras & 0,5 & 0,4 & 0,5 & 0,6 & 0,3 & 0,6 & 0,7 & 1,48 & 1,95 \\
\hline Frutas de clima temperado & 4,0 & 1,3 & 2,3 & 3,6 & 5,4 & 6,5 & 9,9 & 2,46 & 7,38 \\
\hline Ameixa & 0,1 & 0,0 & 0,1 & 0,1 & 0,2 & 0,2 & 0,5 & 3,60 & 22,85 \\
\hline Caqui & 0,2 & 0,0 & 0,0 & 0,2 & 0,2 & 0,3 & 0,6 & 3,24 & 20,78 \\
\hline Maçã & 2,1 & 1,0 & 1,4 & 2,1 & 2,9 & 3,3 & 4,0 & 1,87 & 4,22 \\
\hline Morango & 0,2 & 0,0 & 0,0 & 0,1 & 0,2 & 0,3 & 0,5 & 3,47 & 20,07 \\
\hline Pera & 0,4 & 0,1 & 0,2 & 0,2 & 0,5 & 0,7 & 1,2 & 3,31 & 20,41 \\
\hline Pêssego & 0,2 & 0,0 & 0,1 & 0,2 & 0,3 & 0,4 & 0,7 & 3,51 & 27,67 \\
\hline Uva & 0,8 & 0,2 & 0,4 & 0,7 & 1,0 & 1,2 & 2,1 & 2,78 & 9,33 \\
\hline Outras & 0,1 & 0,0 & 0,0 & 0,1 & 0,1 & 0,2 & 0,3 & 3,27 & 55,00 \\
\hline Cocos, castanhas e nozes & 1,3 & 1,4 & 1,4 & 1,5 & 0,8 & 0,8 & 1,0 & 0,77 & 0,68 \\
\hline Cocos & 1,2 & 1,4 & 1,4 & 1,4 & 0,8 & 0,7 & 0,7 & 0,59 & 0,51 \\
\hline Açaí (emulsão) & 0,8 & 1,0 & 1,1 & 1,0 & 0,5 & 0,3 & 0,3 & 0,41 & 0,33 \\
\hline Coco-da-baía & 0,1 & 0,1 & 0,1 & 0,1 & 0,1 & 0,2 & 0,2 & 1,45 & 2,06 \\
\hline Outros & 0,2 & 0,3 & 0,2 & 0,3 & 0,2 & 0,2 & 0,2 & 0,77 & 0,64 \\
\hline Castanhas e nozes & 0,1 & 0,0 & 0,0 & 0,0 & 0,1 & 0,1 & 0,3 & 3,85 & 6,72 \\
\hline Farinhas, féculas e massas & 18,1 & 21,1 & 19,4 & 18,2 & 15,7 & 14,9 & 15,7 & 0,87 & 0,75 \\
\hline Farinhas & 9,0 & 10,9 & 9,7 & 9,6 & 7,7 & 6,8 & 5,7 & 0,63 & 0,52 \\
\hline Farinha de mandioca & 5,3 & 8,4 & 6,8 & 5,4 & 3,3 & 2,1 & 1,9 & 0,35 & 0,22 \\
\hline Farinha de rosca & 0,1 & 0,0 & 0,0 & 0,0 & 0,1 & 0,1 & 0,1 & 2,33 & 6,76 \\
\hline Farinha de trigo & 3,4 & 2,3 & 2,8 & 3,9 & 4,1 & 4,3 & 3,2 & 0,95 & 1,41 \\
\hline Farinha vitaminada & 0,1 & 0,0 & 0,1 & 0,1 & 0,1 & 0,1 & 0,2 & 2,02 & 3,76 \\
\hline Outras & 0,1 & 0,1 & 0,1 & 0,1 & 0,1 & 0,1 & 0,3 & 1,89 & 1,92 \\
\hline Féculas & 4,3 & 6,1 & 5,0 & 4,0 & 3,2 & 2,7 & 3,9 & 0,90 & 0,65 \\
\hline Amido de milho & 0,1 & 0,1 & 0,1 & 0,1 & 0,1 & 0,1 & 0,1 & 1,18 & 1,07 \\
\hline Creme de arroz & 0,1 & 0,2 & 0,2 & 0,1 & 0,1 & 0,1 & 0,1 & 0,46 & 0,35 \\
\hline Creme de milho & 0,2 & 0,4 & 0,3 & 0,2 & 0,1 & 0,1 & 0,0 & 0,23 & 0,11 \\
\hline Fécula de mandioca & 0,8 & 0,7 & 0,8 & 0,9 & 0,5 & 0,6 & 0,9 & 1,13 & 1,23 \\
\hline Flocos de aveia & 0,1 & 0,0 & 0,0 & 0,1 & 0,1 & 0,1 & 0,2 & 2,51 & 5,64 \\
\hline Flocos de milho & 0,6 & 0,6 & 0,6 & 0,5 & 0,6 & 0,5 & 1,0 & 1,62 & 1,58 \\
\hline Flocos de outros cereais & 0,1 & 0,1 & 0,1 & 0,1 & 0,1 & 0,2 & 0,4 & 3,61 & 5,22 \\
\hline Fubá de milho & 2,3 & 3,8 & 2,9 & 2,0 & 1,6 & 1,0 & 1,2 & 0,51 & 0,30 \\
\hline Outras & 0,0 & 0,0 & 0,0 & 0,0 & 0,0 & 0,0 & 0,0 & 0,73 & 0,33 \\
\hline Massas & 4,7 & 4,1 & 4,6 & 4,5 & 4,9 & 5,4 & 6,1 & 1,29 & 1,48 \\
\hline Macarrão com ovos & 1,1 & 0,6 & 1,0 & 1,1 & 1,3 & 1,2 & 1,5 & 1,44 & 2,44 \\
\hline Macarrão não especificado & 2,7 & 3,0 & 2,9 & 2,7 & 2,5 & 2,5 & 2,8 & 1,01 & 0,93 \\
\hline Macarrão sem ovos & 0,3 & 0,4 & 0,4 & 0,3 & 0,2 & 0,3 & 0,2 & 0,64 & 0,55 \\
\hline Massa de lasanha & 0,2 & 0,0 & 0,1 & 0,1 & 0,2 & 0,5 & 0,4 & 2,61 & 17,13 \\
\hline Massa de pastel & 0,1 & 0,1 & 0,1 & 0,2 & 0,2 & 0,2 & 0,2 & 1,70 & 3,98 \\
\hline Massa de pizza & 0,2 & 0,0 & 0,1 & 0,1 & 0,3 & 0,4 & 0,6 & 3,27 & 15,42 \\
\hline Outras & 0,1 & 0,0 & 0,0 & 0,1 & 0,2 & 0,3 & 0,4 & 3,22 & 13,68 \\
\hline Panificados & 21,5 & 15,3 & 19,2 & 21,4 & 24,7 & 26,0 & 30,4 & 1,41 & 1,99 \\
\hline Pães & 15,8 & 10,6 & 14,2 & 16,2 & 18,5 & 19,0 & 21,7 & 1,37 & 2,05 \\
\hline Pão caseiro & 0,3 & 0,2 & 0,2 & 0,4 & 0,4 & 0,3 & 0,3 & 0,93 & 1,76 \\
\hline Pão de forma de padaria & 0,1 & 0,0 & 0,1 & 0,1 & 0,1 & 0,1 & 0,1 & 1,50 & 3,59 \\
\hline Pão de forma industrializado & 0,9 & 0,2 & 0,4 & 0,7 & 1,2 & 1,6 & 2,3 & 2,70 & 12,04 \\
\hline Pão de milho & 0,1 & 0,1 & 0,1 & 0,1 & 0,1 & 0,2 & 0,2 & 1,74 & 2,56 \\
\hline Pão de queijo & 0,2 & 0,1 & 0,1 & 0,2 & 0,3 & 0,3 & 0,5 & 2,57 & 7,79 \\
\hline
\end{tabular}


Tabela 22 (cont.): Aquisição alimentar domiciliar anual por classe de rendimento

\begin{tabular}{|c|c|c|c|c|c|c|c|c|c|}
\hline \multirow[b]{2}{*}{ Produtos } & \multirow[b]{2}{*}{ Total } & \multicolumn{6}{|c|}{ Classes de rendimento (Salários-Mínimos) } & \multirow{2}{*}{$\begin{array}{c}>15 \mathrm{SM} / \\
\text { Brasil }\end{array}$} & \multirow{2}{*}{$\begin{array}{l}>15 \mathrm{SM} / \\
\text { Até } 2 \mathrm{SM}\end{array}$} \\
\hline & & Até $2^{(1)}$ & De 2 a 3 & De 3 a 6 & De 6 a 10 & De 10 a 15 & Mais de 15 & & \\
\hline Pão doce & 0,9 & 0,4 & 0,5 & 0,7 & 1,1 & 1,5 & 2,3 & 2,64 & 6,54 \\
\hline Pão francês & 12,5 & 9,2 & 12,2 & 13,2 & 14,4 & 13,8 & 14,0 & 1,11 & 1,52 \\
\hline Pão integral & 0,2 & 0,0 & 0,1 & 0,1 & 0,3 & 0,3 & 0,8 & 3,96 & 18,93 \\
\hline Torrada & 0,1 & 0,0 & 0,0 & 0,1 & 0,1 & 0,1 & 0,2 & 2,85 & 7,21 \\
\hline Outros & 0,6 & 0,4 & 0,5 & 0,5 & 0,6 & 0,7 & 1,0 & 1,79 & 2,29 \\
\hline Bolos & 0,9 & 0,4 & 0,6 & 0,7 & 1,1 & 1,5 & 2,3 & 2,57 & 5,33 \\
\hline Biscoitos, roscas, etc. & 4,8 & 4,3 & 4,4 & 4,5 & 5,1 & 5,6 & 6,4 & 1,33 & 1,49 \\
\hline Biscoito doce & 2,3 & 1,8 & 2,0 & 2,2 & 2,6 & 3,0 & 3,5 & 1,50 & 1,93 \\
\hline Biscoito não especificado & 0,2 & 0,1 & 0,2 & 0,2 & 0,2 & 0,2 & 0,4 & 1,83 & 2,87 \\
\hline Biscoito salgado & 2,0 & 2,1 & 2,0 & 1,9 & 1,9 & 2,0 & 2,1 & 1,07 & 1,02 \\
\hline Rosca doce & 0,1 & 0,1 & 0,1 & 0,1 & 0,1 & 0,1 & 0,2 & 1,87 & 3,39 \\
\hline Rosca não especificada & 0,1 & 0,1 & 0,1 & 0,1 & 0,2 & 0,1 & 0,1 & 0,88 & 0,73 \\
\hline Rosca salgada & 0,0 & 0,0 & 0,0 & 0,0 & 0,0 & 0,0 & 0,0 & 1,47 & 1,40 \\
\hline Outros & 0,0 & 0,0 & 0,0 & 0,0 & 0,0 & 0,1 & 0,0 & 2,21 & 10,50 \\
\hline Carnes & 25,4 & 17,9 & 22,2 & 25,5 & 30,3 & 33,7 & 31,9 & 1,25 & 1,78 \\
\hline Carnes bovinas de primeira & 6,1 & 2,8 & 4,3 & 5,7 & 8,0 & 9,6 & 11,3 & 1,87 & 3,98 \\
\hline Alcatra & 0,9 & 0,2 & 0,4 & 0,6 & 1,3 & 1,6 & 2,6 & 3,01 & 13,11 \\
\hline Carne moída & 0,4 & 0,1 & 0,2 & 0,3 & 0,4 & 0,6 & 0,8 & 2,38 & 7,79 \\
\hline Carne não especificada & 2,5 & 1,8 & 2,4 & 2,6 & 2,9 & 2,8 & 3,2 & 1,27 & 1,75 \\
\hline Chã de dentro & 0,6 & 0,2 & 0,4 & 0,6 & 1,1 & 1,2 & 1,0 & 1,56 & 5,95 \\
\hline Contrafilé & 0,8 & 0,2 & 0,4 & 0,7 & 1,3 & 1,9 & 1,5 & 1,85 & 6,65 \\
\hline Filé-mignon & 0,1 & 0,0 & 0,0 & 0,1 & 0,1 & 0,1 & 0,8 & 6,38 & 106,13 \\
\hline Lagarto comum & 0,2 & 0,1 & 0,1 & 0,2 & 0,3 & 0,4 & 0,4 & 1,72 & 3,27 \\
\hline Lagarto redondo & 0,0 & 0,0 & 0,0 & 0,0 & 0,1 & 0,1 & 0,1 & 1,95 & 8,67 \\
\hline Patinho & 0,4 & 0,2 & 0,3 & 0,4 & 0,5 & 0,9 & 0,8 & 1,86 & 4,76 \\
\hline Carnes bovinas de segunda & 6,9 & 6,0 & 7,0 & 7,3 & 7,4 & 6,9 & 6,3 & 0,91 & 1,04 \\
\hline Acém & 0,7 & 0,4 & 0,6 & 0,8 & 1,1 & 0,7 & 0,7 & 1,02 & 1,89 \\
\hline Capa de filé & 0,1 & 0,0 & 0,0 & 0,1 & 0,1 & 0,2 & 0,3 & 2,48 & 11,12 \\
\hline Carne moída & 0,8 & 0,6 & 0,9 & 0,9 & 1,1 & 0,9 & 0,7 & 0,80 & 1,15 \\
\hline Carne não especificada & 2,5 & 3,1 & 2,8 & 2,5 & 1,9 & 2,1 & 1,5 & 0,61 & 0,49 \\
\hline Costela & 1,5 & 1,1 & 1,5 & 1,6 & 1,5 & 1,6 & 1,5 & 1,05 & 1,39 \\
\hline Músculo & 0,4 & 0,2 & 0,2 & 0,4 & 0,6 & 0,4 & 0,5 & 1,40 & 3,19 \\
\hline Pá & 0,3 & 0,2 & 0,3 & 0,4 & 0,4 & 0,4 & 0,4 & 1,04 & 1,60 \\
\hline Peito & 0,2 & 0,1 & 0,2 & 0,2 & 0,3 & 0,2 & 0,3 & 1,40 & 2,15 \\
\hline Outras & 0,4 & 0,4 & 0,4 & 0,4 & 0,4 & 0,4 & 0,4 & 1,04 & 1,15 \\
\hline Carnes bovinas outras & 4,1 & 3,8 & 4,2 & 4,0 & 4,2 & 4,7 & 3,9 & 0,96 & 1,03 \\
\hline Carne de hambúrguer & 0,2 & 0,1 & 0,2 & 0,2 & 0,3 & 0,3 & 0,3 & 1,58 & 3,95 \\
\hline Carne de sol & 0,3 & 0,4 & 0,3 & 0,3 & 0,2 & 0,2 & 0,2 & 0,82 & 0,61 \\
\hline Carne moída não especificada & 0,4 & 0,2 & 0,3 & 0,4 & 0,4 & 0,3 & 0,4 & 1,24 & 1,80 \\
\hline Carne não especificada & 1,8 & 1,5 & 1,8 & 1,8 & 1,8 & 2,7 & 1,6 & 0,90 & 1,08 \\
\hline Carne-seca & 0,5 & 0,6 & 0,6 & 0,5 & 0,4 & 0,4 & 0,4 & 0,84 & 0,71 \\
\hline Mocotó & 0,1 & 0,1 & 0,1 & 0,1 & 0,1 & 0,0 & 0,1 & 0,86 & 1,00 \\
\hline Outras & 0,9 & 0,9 & 0,9 & 0,9 & 0,9 & 0,7 & 0,8 & 0,92 & 0,88 \\
\hline Carnes suínas com osso e sem oss & 2,3 & 1,2 & 1,7 & 2,1 & 3,4 & 5,0 & 2,5 & 1,10 & 2,04 \\
\hline Carré & 0,3 & 0,1 & 0,3 & 0,3 & 0,5 & 0,6 & 0,4 & 1,21 & 2,74 \\
\hline Costela & 0,3 & 0,1 & 0,1 & 0,3 & 0,4 & 0,4 & 0,5 & 1,90 & 5,86 \\
\hline Lombo & 0,1 & 0,0 & 0,0 & 0,1 & 0,1 & 0,2 & 0,3 & 3,05 & 14,06 \\
\hline Pernil & 0,3 & 0,1 & 0,1 & 0,3 & 0,6 & 0,3 & 0,6 & 2,07 & 8,55 \\
\hline Porco eviscerado & 0,2 & 0,0 & 0,1 & 0,1 & 0,2 & 1,6 & 0,2 & 0,69 & 7,89 \\
\hline Outras & 1,1 & 0,9 & 1,0 & 1,0 & 1,7 & 1,9 & 0,6 & 0,56 & 0,70 \\
\hline Carnes suínas outras & 3,2 & 2,1 & 2,7 & 3,1 & 4,1 & 4,1 & 4,7 & 1,46 & 2,21 \\
\hline Carne salgada não especificada & 0,1 & 0,1 & 0,1 & 0,1 & 0,1 & 0,2 & 0,1 & 1,05 & 0,86 \\
\hline Costela de porco salgada & 0,0 & 0,0 & 0,0 & 0,0 & 0,1 & 0,0 & 0,0 & 0,21 & 0,31 \\
\hline Mortadela & 0,8 & 0,7 & 0,9 & 0,9 & 0,9 & 0,8 & 0,8 & 0,96 & 1,09 \\
\hline Paio & 0,0 & - & 0,0 & 0,0 & 0,0 & 0,0 & 0,0 & 4,00 & - \\
\hline Pé de porco salgado & 0,0 & 0,0 & 0,0 & 0,0 & 0,1 & 0,0 & 0,0 & 0,34 & 0,48 \\
\hline Presunto & 0,5 & 0,1 & 0,2 & 0,4 & 0,8 & 0,9 & 1,3 & 2,71 & 11,46 \\
\hline Salame & 0,2 & 0,1 & 0,1 & 0,1 & 0,2 & 0,2 & 0,3 & 2,03 & 2,24 \\
\hline Salsicha comum & 1,2 & 0,7 & 1,0 & 1,2 & 1,5 & 1,3 & 1,5 & 1,33 & 2,09 \\
\hline Toucinho fresco & 0,2 & 0,1 & 0,2 & 0,2 & 0,3 & 0,2 & 0,1 & 0,49 & 0,67 \\
\hline Toucinho defumado & 0,1 & 0,0 & 0,1 & 0,1 & 0,2 & 0,2 & 0,3 & 2,87 & 17,88 \\
\hline Outras & 0,1 & 0,1 & 0,1 & 0,1 & 0,2 & 0,3 & 0,2 & 1,45 & 2,16 \\
\hline Carnes de outros animais & 2,8 & 1,9 & 2,3 & 3,3 & 3,3 & 3,4 & 3,1 & 1,10 & 1,67 \\
\hline Carne de cabrito & 0,1 & 0,1 & 0,1 & 0,1 & 0,1 & 0,1 & 0,0 & 0,37 & 0,30 \\
\hline Carne de carneiro & 0,2 & 0,1 & 0,2 & 0,3 & 0,1 & 0,2 & 0,4 & 1,87 & 4,65 \\
\hline Linguiça & 2,1 & 1,2 & 1,6 & 2,3 & 2,9 & 2,8 & 2,4 & 1,16 & 2,00 \\
\hline Outras & 0,4 & 0,4 & 0,4 & 0,6 & 0,2 & 0,3 & 0,3 & 0,61 & 0,59 \\
\hline
\end{tabular}


Tabela 22 (cont.): Aquisição alimentar domiciliar anual por classe de rendimento

\begin{tabular}{|c|c|c|c|c|c|c|c|c|c|}
\hline \multirow[b]{2}{*}{ Produtos } & \multirow[b]{2}{*}{ Total } & \multicolumn{6}{|c|}{ Classes de rendimento (Salários-Mínim os) } & \multirow{2}{*}{$\begin{array}{c}>15 \mathrm{SM} / \\
\text { Brasil }\end{array}$} & \multirow{2}{*}{$\begin{array}{l}>15 \mathrm{SM} / \\
\text { Até } 2 \mathrm{SM}\end{array}$} \\
\hline & & Até $2^{(1)}$ & De 2 a 3 & De 3 a 6 & De 6 a 10 & De 10 a 15 & Mais de 15 & & \\
\hline Vísceras & 0,7 & 0,6 & 0,8 & 0,8 & 0,7 & 0,7 & 0,5 & 0,71 & 0,81 \\
\hline Vísceras bovinas & 0,6 & 0,6 & 0,7 & 0,7 & 0,6 & 0,6 & 0,4 & 0,69 & 0,74 \\
\hline Bucho & 0,1 & 0,1 & 0,0 & 0,1 & 0,1 & 0,1 & 0,0 & 0,57 & 0,76 \\
\hline Fígado & 0,4 & 0,3 & 0,5 & 0,4 & 0,4 & 0,3 & 0,3 & 0,73 & 0,88 \\
\hline Língua & 0,0 & 0,0 & 0,0 & 0,0 & 0,0 & 0,0 & 0,0 & 1,65 & 1,52 \\
\hline Outras & 0,2 & 0,2 & 0,2 & 0,2 & 0,1 & 0,2 & 0,1 & 0,50 & 0,40 \\
\hline Vísceras suínas & 0,1 & 0,0 & 0,1 & 0,1 & 0,1 & 0,1 & 0,1 & 0,96 & 1,94 \\
\hline Outras vísceras & 0,0 & 0,0 & 0,0 & 0,0 & 0,0 & 0,0 & 0,0 & 0,75 & 1,29 \\
\hline Pescados & 4,0 & 4,5 & 4,3 & 3,7 & 3,5 & 3,2 & 5,1 & 1,26 & 1,12 \\
\hline Pescados de água salgada & 1,9 & 1,7 & 1,8 & 1,6 & 1,9 & 1,7 & 3,5 & 1,82 & 1,99 \\
\hline Anchova fresca & 0,0 & 0,0 & - & 0,0 & 0,0 & 0,0 & 0,0 & 0,36 & 0,50 \\
\hline Bacalhau & 0,1 & 0,0 & 0,0 & 0,1 & 0,1 & 0,1 & 0,3 & 4,08 & 13,73 \\
\hline Bagre fresco & 0,1 & 0,1 & 0,0 & 0,1 & 0,0 & - & 0,0 & 0,07 & 0,03 \\
\hline Cação fresco & 0,0 & 0,0 & 0,0 & 0,0 & 0,0 & 0,0 & 0,1 & 3,24 & 20,25 \\
\hline Camarão fresco & 0,2 & 0,1 & 0,1 & 0,1 & 0,2 & 0,1 & 0,5 & 3,01 & 4,49 \\
\hline Corvina fresca & 0,1 & 0,1 & 0,1 & 0,1 & 0,2 & 0,1 & 0,2 & 1,27 & 1,33 \\
\hline Merluza em filé congelado & 0,1 & 0,0 & 0,0 & 0,0 & 0,1 & 0,1 & 0,2 & 2,63 & 13,17 \\
\hline Merluza em filé fresco & 0,0 & 0,0 & 0,0 & 0,0 & 0,0 & 0,0 & 0,0 & 2,29 & 39,00 \\
\hline Parati fresco & 0,0 & 0,0 & 0,0 & 0,0 & - & - & - & - & - \\
\hline Pescada em filé congelado & 0,0 & 0,0 & 0,0 & 0,0 & 0,0 & 0,1 & 0,1 & 3,46 & 24,25 \\
\hline Pescada em filé fresco & 0,0 & 0,0 & 0,0 & 0,0 & 0,0 & 0,0 & 0,1 & 3,74 & 17,75 \\
\hline Pescada fresca & 0,3 & 0,3 & 0,3 & 0,2 & 0,2 & 0,2 & 0,2 & 0,97 & 0,77 \\
\hline Pescadinha fresca & 0,0 & 0,0 & 0,0 & 0,0 & 0,0 & 0,0 & 0,0 & 0,57 & 0,33 \\
\hline Sardinha em conserva & 0,1 & 0,1 & 0,1 & 0,2 & 0,2 & 0,2 & 0,2 & 1,03 & 1,34 \\
\hline Sardinha fresca & 0,1 & 0,1 & 0,1 & 0,1 & 0,2 & 0,0 & 0,0 & 0,34 & 0,35 \\
\hline Tainha fresca & 0,1 & 0,1 & 0,2 & 0,1 & 0,1 & 0,1 & 0,0 & 0,18 & 0,17 \\
\hline Outros pescados em filé congelado & 0,1 & 0,1 & 0,0 & 0,1 & 0,1 & 0,2 & 0,7 & 5,56 & 10,07 \\
\hline Outros pescados em filé fresco & 0,1 & 0,1 & 0,0 & 0,1 & 0,1 & 0,1 & 0,3 & 3,16 & 4,62 \\
\hline Outros pescados frescos & 0,4 & 0,4 & 0,5 & 0,3 & 0,4 & 0,3 & 0,5 & 1,34 & 1,27 \\
\hline Outros pescados salgados & 0,0 & 0,0 & 0,0 & 0,0 & 0,0 & 0,0 & 0,0 & 0,59 & 0,57 \\
\hline Pescados de água doce & 1,6 & 2,1 & 2,0 & 1,6 & 1,1 & 1,0 & 0,8 & 0,53 & 0,40 \\
\hline Acará fresca & 0,1 & 0,1 & 0,1 & 0,1 & 0,0 & 0,0 & 0,0 & 0,01 & 0,01 \\
\hline Acari fresco & 0,0 & 0,0 & 0,1 & 0,0 & 0,0 & - & 0,0 & 0,66 & 0,49 \\
\hline Anujá fresco & 0,0 & 0,1 & 0,1 & 0,0 & 0,0 & 0,0 & 0,0 & 0,21 & 0,13 \\
\hline Curimatã fresco & 0,1 & 0,2 & 0,2 & 0,1 & 0,1 & 0,0 & 0,1 & 0,44 & 0,32 \\
\hline Dourada fresca & 0,1 & 0,1 & 0,0 & 0,0 & 0,1 & 0,0 & 0,0 & 0,84 & 0,72 \\
\hline Jaraqui fresco & 0,1 & 0,1 & 0,2 & 0,1 & 0,2 & 0,0 & 0,0 & 0,25 & 0,21 \\
\hline Lambari fresco & 0,1 & 0,1 & 0,1 & 0,0 & 0,0 & 0,1 & 0,0 & 0,20 & 0,11 \\
\hline Mapará fresco & 0,0 & 0,0 & 0,1 & 0,0 & 0,0 & 0,0 & 0,0 & 0,06 & 0,06 \\
\hline Piau fresco & 0,0 & 0,0 & 0,0 & 0,0 & 0,0 & 0,0 & 0,1 & 1,39 & 1,32 \\
\hline Surubim fresco & 0,1 & 0,0 & 0,0 & 0,1 & 0,1 & 0,0 & 0,0 & 0,70 & 1,67 \\
\hline Tambaqui fresco & 0,1 & 0,2 & 0,1 & 0,2 & 0,1 & 0,1 & 0,1 & 0,82 & 0,69 \\
\hline Tilápia fresca & 0,1 & 0,1 & 0,1 & 0,1 & 0,0 & 0,0 & 0,0 & 0,49 & 0,41 \\
\hline Traíra fresca & 0,1 & 0,1 & 0,1 & 0,1 & 0,0 & 0,0 & 0,0 & 0,26 & 0,16 \\
\hline Tucunaré fresco & 0,0 & 0,1 & 0,1 & 0,0 & 0,0 & 0,0 & 0,0 & 0,17 & 0,13 \\
\hline Outros pescados em filé congelado & 0,1 & 0,0 & 0,0 & 0,0 & 0,1 & 0,1 & 0,1 & 1,98 & 13,13 \\
\hline Outros pescados em filé fresco & 0,0 & 0,0 & 0,0 & 0,0 & 0,0 & 0,1 & 0,0 & 1,17 & 3,82 \\
\hline Outros pescados frescos & 0,5 & 0,8 & 0,6 & 0,5 & 0,3 & 0,4 & 0,2 & 0,44 & 0,29 \\
\hline Outros pescados salgados & 0,0 & 0,0 & 0,0 & 0,0 & 0,0 & 0,0 & 0,0 & 0,56 & 0,34 \\
\hline Pescados não especificados & 0,6 & 0,7 & 0,5 & 0,5 & 0,4 & 0,5 & 0,8 & 1,41 & 1,13 \\
\hline Peixe em filé congelado & 0,0 & 0,0 & 0,0 & 0,0 & 0,0 & 0,0 & 0,1 & 4,86 & 15,29 \\
\hline Peixe em filé fresco & 0,0 & 0,0 & 0,0 & 0,0 & 0,0 & 0,0 & 0,0 & 3,75 & 10,00 \\
\hline Peixe fresco & 0,5 & 0,7 & 0,5 & 0,5 & 0,4 & 0,5 & 0,6 & 1,23 & 0,95 \\
\hline Peixe salgado & 0,0 & 0,0 & 0,0 & 0,0 & 0,0 & - & 0,0 & 1,16 & 0,76 \\
\hline Aves e ovos & 16,4 & 14,0 & 15,9 & 16,8 & 17,9 & 17,3 & 18,2 & 1,11 & 1,31 \\
\hline Aves & 13,2 & 11,3 & 12,8 & 13,5 & 14,4 & 13,8 & 14,5 & 1,10 & 1,28 \\
\hline Asa de frango & 0,5 & 0,2 & 0,4 & 0,5 & 0,6 & 0,8 & 0,6 & 1,29 & 3,81 \\
\hline Carne de frango não especificada & 1,0 & 1,2 & 1,0 & 0,9 & 0,9 & 0,7 & 0,9 & 0,90 & 0,71 \\
\hline Coxa de frango & 1,6 & 0,6 & 1,0 & 1,8 & 2,0 & 2,6 & 2,5 & 1,57 & 3,92 \\
\hline Dorso de frango & 0,1 & 0,2 & 0,1 & 0,2 & 0,1 & 0,1 & 0,0 & 0,31 & 0,19 \\
\hline Frango abatido (inteiro) & 7,8 & 8,1 & 8,9 & 8,2 & 7,8 & 6,0 & 5,4 & 0,70 & 0,67 \\
\hline Frango vivo & 0,2 & 0,3 & 0,3 & 0,3 & 0,2 & 0,3 & 0,1 & 0,37 & 0,29 \\
\hline Miúdos de frango & 0,2 & 0,1 & 0,1 & 0,1 & 0,2 & 0,2 & 0,3 & 1,69 & 2,76 \\
\hline Peito de frango & 1,5 & 0,5 & 0,8 & 1,3 & 2,2 & 2,4 & 3,9 & 2,58 & 8,49 \\
\hline Outras carnes de frango & 0,2 & 0,1 & 0,1 & 0,2 & 0,2 & 0,2 & 0,4 & 2,36 & 4,28 \\
\hline Pato inteiro ou em cortes & 0,0 & 0,0 & 0,0 & 0,0 & 0,0 & - & 0,0 & 1,69 & 3,00 \\
\hline Peru abatido & 0,0 & 0,0 & 0,0 & 0,0 & 0,1 & 0,2 & 0,1 & 2,12 & 87,00 \\
\hline
\end{tabular}


Tabela 22 (cont.): Aquisição alimentar domiciliar anual por classe de rendimento

\begin{tabular}{|c|c|c|c|c|c|c|c|c|c|}
\hline \multirow[b]{2}{*}{ Produtos } & \multirow[b]{2}{*}{ Total } & \multicolumn{6}{|c|}{ Classes de rendimento (Salários-Mínimos) } & \multirow{2}{*}{$\begin{array}{c}>15 \mathrm{SM} / \\
\text { Brasil }\end{array}$} & \multirow{2}{*}{$\begin{array}{l}>15 \mathrm{SM} / \\
\text { Até } 2 \mathrm{SM}\end{array}$} \\
\hline & & Até $2^{(1)}$ & De 2 a 3 & De 3 a 6 & De 6 a 10 & De 10 a 15 & Mais de 15 & & \\
\hline Peru em cortes & 0,1 & 0,0 & 0,0 & 0,1 & 0,1 & 0,1 & 0,3 & 3,47 & 9,93 \\
\hline Outras & 0,0 & 0,0 & 0,0 & 0,0 & 0,0 & 0,1 & 0,0 & 0,39 & 0,53 \\
\hline Ovos & 3,2 & 2,6 & 3,0 & 3,3 & 3,4 & 3,6 & 3,7 & 1,17 & 1,42 \\
\hline Ovo de galinha & 3,2 & 2,6 & 3,0 & 3,3 & 3,4 & 3,6 & 3,7 & 1,15 & 1,40 \\
\hline Outros & 0,0 & 0,0 & 0,0 & 0,0 & 0,0 & 0,0 & 0,1 & 3,80 & 19,00 \\
\hline Laticínios & 43,7 & 25,1 & 36,0 & 43,8 & 53,8 & 60,8 & 66,3 & 1,52 & 2,64 \\
\hline Leite e creme de leite & 38,4 & 23,2 & 32,8 & 39,3 & 46,9 & 52,4 & 52,8 & 1,37 & 2,28 \\
\hline Creme de leite & 0,4 & 0,1 & 0,2 & 0,3 & 0,6 & 0,7 & 1,0 & 2,56 & 10,68 \\
\hline Leite condensado & 0,7 & 0,2 & 0,4 & 0,6 & 1,0 & 1,1 & 1,5 & 2,32 & 8,06 \\
\hline Leite de vaca fresco & 9,8 & 9,9 & 12,8 & 11,4 & 7,7 & 6,2 & 5,4 & 0,55 & 0,54 \\
\hline Leite de vaca pasteurizado & 25,6 & 11,6 & 18,1 & 25,4 & 35,6 & 41,5 & 40,2 & 1,57 & 3,46 \\
\hline Leite em pó desengordurado & 0,1 & 0,1 & 0,1 & 0,1 & 0,1 & 0,2 & 0,2 & 1,91 & 2,44 \\
\hline Leite em pó integral & 0,8 & 0,9 & 0,8 & 0,8 & 0,7 & 0,7 & 0,9 & 1,17 & 1,09 \\
\hline Leite em pó não especificado & 0,1 & 0,1 & 0,1 & 0,1 & 0,1 & 0,1 & 0,1 & 0,94 & 0,94 \\
\hline Outros & 1,0 & 0,3 & 0,4 & 0,6 & 1,2 & 1,9 & 3,4 & 3,58 & 11,03 \\
\hline Queijos e requeijão & 2,2 & 0,7 & 1,1 & 1,7 & 3,0 & 3,4 & 6,3 & 2,91 & 9,47 \\
\hline Queijo minas & 0,7 & 0,3 & 0,5 & 0,6 & 0,9 & 0,9 & 1,7 & 2,51 & 5,17 \\
\hline Queijo mozzarella & 0,7 & 0,1 & 0,2 & 0,5 & 1,0 & 1,2 & 1,9 & 2,98 & 14,63 \\
\hline Queijo não especificado & 0,1 & 0,0 & 0,1 & 0,1 & 0,1 & 0,1 & 0,2 & 2,18 & 5,64 \\
\hline Queijo parmezão & 0,1 & 0,0 & 0,0 & 0,0 & 0,1 & 0,1 & 0,3 & 4,05 & 25,10 \\
\hline Queijo prato & 0,3 & 0,1 & 0,1 & 0,3 & 0,5 & 0,6 & 0,9 & 2,58 & 11,10 \\
\hline Outros queijos & 0,1 & 0,0 & 0,0 & 0,0 & 0,1 & 0,2 & 0,5 & 5,41 & 30,67 \\
\hline Requeijão & 0,2 & 0,1 & 0,1 & 0,2 & 0,3 & 0,4 & 0,8 & 3,37 & 14,05 \\
\hline Outros laticínios & 3,1 & 1,3 & 2,1 & 2,8 & 3,9 & 5,0 & 7,2 & 2,32 & 5,62 \\
\hline logurte & 2,1 & 0,9 & 1,4 & 1,9 & 2,5 & 3,2 & 4,3 & 2,10 & 4,79 \\
\hline Leite fermentado & 0,7 & 0,2 & 0,5 & 0,5 & 0,9 & 1,3 & 2,0 & 2,85 & 10,59 \\
\hline Manteiga & 0,3 & 0,2 & 0,2 & 0,2 & 0,3 & 0,3 & 0,8 & 2,76 & 4,38 \\
\hline Outros & 0,1 & 0,0 & 0,0 & 0,1 & 0,1 & 0,1 & 0,1 & 1,79 & 5,38 \\
\hline Açúcares, doces e confeitaria & 20,5 & 19,3 & 20,5 & 21,1 & 19,0 & 21,2 & 23,4 & 1,14 & 1,21 \\
\hline Açúcares & 17,0 & 17,6 & 18,4 & 18,2 & 14,7 & 15,7 & 14,0 & 0,82 & 0,79 \\
\hline Açúcar cristal & 8,0 & 6,9 & 8,0 & 9,3 & 8,1 & 7,4 & 6,9 & 0,86 & 1,01 \\
\hline Açúcar demerara & 0,2 & 0,1 & 0,1 & 0,1 & 0,2 & 0,3 & 0,2 & 1,43 & 1,96 \\
\hline Açúcar não especificado & 5,5 & 8,2 & 7,0 & 5,3 & 3,0 & 4,1 & 3,7 & 0,66 & 0,45 \\
\hline Açúcar refinado & 3,2 & 2,5 & 3,2 & 3,4 & 3,3 & 3,9 & 3,0 & 0,94 & 1,21 \\
\hline Outros & 0,0 & 0,0 & 0,0 & 0,0 & 0,0 & 0,0 & 0,1 & 3,11 & 11,80 \\
\hline Doces e produtos de confeitaria & 2,6 & 1,3 & 1,5 & 2,0 & 3,0 & 4,0 & 7,5 & 2,87 & 5,77 \\
\hline Bombom & 0,2 & 0,1 & 0,1 & 0,2 & 0,3 & 0,5 & 0,6 & 2,82 & 8,98 \\
\hline Chocolate em tablete & 0,2 & 0,0 & 0,1 & 0,1 & 0,3 & 0,3 & 0,6 & 3,70 & 22,07 \\
\hline Doce a base de leite & 0,2 & 0,1 & 0,1 & 0,2 & 0,2 & 0,2 & 0,2 & 1,56 & 2,73 \\
\hline Doce de fruta cristalizado & 0,0 & 0,0 & 0,0 & 0,0 & 0,0 & 0,0 & 0,1 & 2,81 & 2,43 \\
\hline Doce de fruta em calda & 0,1 & 0,0 & 0,0 & 0,1 & 0,1 & 0,2 & 0,3 & 3,10 & 20,00 \\
\hline Doce de fruta em pasta & 0,3 & 0,2 & 0,2 & 0,2 & 0,2 & 0,4 & 0,5 & 1,96 & 2,82 \\
\hline Rapadura & 0,1 & 0,2 & 0,2 & 0,1 & 0,1 & 0,0 & 0,1 & 0,46 & 0,33 \\
\hline Sorvete & 0,7 & 0,1 & 0,2 & 0,4 & 0,9 & 1,3 & 2,7 & 3,98 & 24,85 \\
\hline Outros & 0,9 & 0,6 & 0,6 & 0,7 & 0,9 & 1,2 & 2,4 & 2,68 & 3,91 \\
\hline Outros açúcares, doces e confeitaria & 1,0 & 0,4 & 0,6 & 0,9 & 1,3 & 1,4 & 2,0 & 2,05 & 5,26 \\
\hline Chocolate em pó & 0,7 & 0,3 & 0,5 & 0,6 & 1,0 & 1,0 & 1,3 & 1,83 & 4,61 \\
\hline Gelatina & 0,1 & 0,0 & 0,0 & 0,1 & 0,1 & 0,1 & 0,2 & 2,10 & 8,50 \\
\hline Mel de abelha & 0,0 & 0,0 & 0,0 & 0,0 & 0,1 & 0,0 & 0,1 & 2,90 & 3,97 \\
\hline Polpa de fruta & 0,1 & 0,0 & 0,0 & 0,1 & 0,1 & 0,2 & 0,4 & 3,22 & 8,53 \\
\hline Outros & 0,0 & 0,0 & 0,0 & 0,1 & 0,0 & 0,0 & 0,0 & 1,00 & 14,00 \\
\hline Sais e condimentos & 5,4 & 4,2 & 4,9 & 5,6 & 5,9 & 6,2 & 7,1 & 1,31 & 1,71 \\
\hline Sais & 2,5 & 2,8 & 2,8 & 2,6 & 2,2 & 1,9 & 2,0 & 0,81 & 0,73 \\
\hline Sal grosso & 0,4 & 0,3 & 0,5 & 0,4 & 0,5 & 0,2 & 0,5 & 1,19 & 1,37 \\
\hline Sal refinado & 2,1 & 2,4 & 2,3 & 2,2 & 1,7 & 1,7 & 1,5 & 0,74 & 0,64 \\
\hline Outros & 0,0 & 0,0 & 0,0 & 0,0 & 0,0 & 0,0 & 0,0 & 2,50 & 5,00 \\
\hline Condimentos & 3,0 & 1,4 & 2,1 & 3,0 & 3,8 & 4,3 & 5,1 & 1,72 & 3,60 \\
\hline Caldo de carne em tablete & 0,0 & 0,0 & 0,0 & 0,0 & 0,0 & 0,1 & 0,0 & 1,38 & 2,76 \\
\hline Caldo de galinha em tablete & 0,0 & 0,0 & 0,0 & 0,1 & 0,1 & 0,1 & 0,1 & 1,36 & 2,65 \\
\hline Outros caldos em tablete & 0,0 & 0,0 & 0,0 & 0,1 & 0,0 & 0,1 & 0,1 & 1,75 & 2,40 \\
\hline Colorau & 0,1 & 0,1 & 0,1 & 0,1 & 0,1 & 0,0 & 0,0 & 0,35 & 0,23 \\
\hline Fermento & 0,1 & 0,0 & 0,1 & 0,1 & 0,1 & 0,1 & 0,1 & 1,35 & 3,15 \\
\hline Leite de coco & 0,1 & 0,0 & 0,0 & 0,1 & 0,1 & 0,1 & 0,2 & 3,19 & 9,90 \\
\hline Maionese & 0,4 & 0,1 & 0,2 & 0,4 & 0,6 & 0,5 & 0,8 & 2,10 & 6,67 \\
\hline Massa de tomate & 0,7 & 0,3 & 0,5 & 0,8 & 0,9 & 0,9 & 0,8 & 1,14 & 2,29 \\
\hline Molho de tomate & 0,6 & 0,2 & 0,3 & 0,6 & 0,8 & 1,1 & 1,6 & 2,47 & 8,95 \\
\hline Tempero misto & 0,1 & 0,1 & 0,1 & 0,2 & 0,2 & 0,3 & 0,2 & 1,13 & 1,90 \\
\hline
\end{tabular}


Tabela 22 (cont.): Aquisição alimentar domiciliar anual por classe de rendimento

\begin{tabular}{|c|c|c|c|c|c|c|c|c|c|}
\hline \multirow[b]{2}{*}{ Produtos } & \multirow[b]{2}{*}{ Total } & \multicolumn{6}{|c|}{ Classes de rendimento (Salários-Mínimos) } & \multirow{2}{*}{$\begin{array}{c}>15 \mathrm{SM} / \\
\text { Brasil }\end{array}$} & \multirow{2}{*}{$\begin{array}{l}>15 \mathrm{SM} / \\
\text { Até } 2 \mathrm{SN}\end{array}$} \\
\hline & & Até $2^{(1)}$ & De 2 a 3 & De 3 a 6 & De 6 a 10 & De 10 a 15 & Mais de 15 & & \\
\hline Vinagre de álcool & 0,2 & 0,2 & 0,2 & 0,2 & 0,3 & 0,4 & 0,2 & 0,94 & 1,06 \\
\hline Vinagre de vinho & 0,1 & 0,0 & 0,1 & 0,1 & 0,1 & 0,1 & 0,2 & 2,16 & 5,41 \\
\hline Vinagre não especificado & 0,2 & 0,1 & 0,1 & 0,2 & 0,2 & 0,3 & 0,3 & 1,71 & 4,85 \\
\hline Outros & 0,3 & 0,1 & 0,2 & 0,3 & 0,3 & 0,3 & 0,5 & 1,98 & 3,68 \\
\hline Óleos e gorduras & 8,9 & 7,6 & 8,7 & 9,2 & 9,4 & 9,8 & 9,9 & 1,11 & 1,31 \\
\hline Óleos & 7,1 & 6,2 & 7,1 & 7,4 & 7,3 & 7,5 & 7,7 & 1,08 & 1,25 \\
\hline Azeite de oliva & 0,2 & 0,0 & 0,1 & 0,1 & 0,2 & 0,4 & 0,6 & 3,56 & 13,78 \\
\hline Óleo de girassol & 0,1 & 0,1 & 0,0 & 0,1 & 0,2 & 0,2 & 0,6 & 4,12 & 8,67 \\
\hline Óleo de canola & 0,1 & 0,0 & 0,0 & 0,0 & 0,1 & 0,1 & 0,4 & 5,91 & 189,00 \\
\hline Óleo de milho & 0,1 & 0,0 & 0,1 & 0,1 & 0,1 & 0,1 & 0,5 & 4,10 & 21,54 \\
\hline Óleo de soja & 6,3 & 5,7 & 6,6 & 6,8 & 6,6 & 6,4 & 5,3 & 0,83 & 0,92 \\
\hline Óleo não especificado & 0,1 & 0,1 & 0,1 & 0,1 & 0,1 & 0,1 & 0,2 & 2,04 & 1,84 \\
\hline Outros & 0,1 & 0,2 & 0,1 & 0,1 & 0,1 & 0,2 & 0,1 & 0,52 & 0,47 \\
\hline Gorduras & 1,8 & 1,4 & 1,6 & 1,8 & 2,1 & 2,3 & 2,2 & 1,22 & 1,57 \\
\hline Banha de porco & 0,1 & 0,1 & 0,2 & 0,2 & 0,1 & 0,1 & 0,1 & 0,51 & 0,56 \\
\hline Margarina vegetal & 1,7 & 1,3 & 1,4 & 1,7 & 1,9 & 2,2 & 2,1 & 1,27 & 1,67 \\
\hline Outras & 0,0 & 0,0 & 0,0 & 0,0 & 0,0 & 0,0 & 0,0 & 1,00 & 0,83 \\
\hline Alimentos preparados e misturas & 3,5 & 1,4 & 1,8 & 2,9 & 4,9 & 6,5 & 8,4 & 2,38 & 6,14 \\
\hline Alimentos preparados & 3,2 & 1,2 & 1,6 & 2,6 & 4,4 & 6,1 & 8,0 & 2,49 & 6,57 \\
\hline Alimento congelado & 0,1 & 0,0 & 0,0 & 0,0 & 0,1 & 0,1 & 0,3 & 4,42 & 17,94 \\
\hline Batata frita & 0,1 & 0,0 & 0,0 & 0,1 & 0,1 & 0,2 & 0,4 & 3,54 & 22,81 \\
\hline Carne-assada & 0,1 & 0,0 & 0,1 & 0,1 & 0,1 & 0,3 & 0,3 & 2,78 & 8,07 \\
\hline Frango assado ou defumado & 0,7 & 0,3 & 0,4 & 0,8 & 0,9 & 1,2 & 1,4 & 1,91 & 4,64 \\
\hline Frango empanado & 0,2 & 0,1 & 0,1 & 0,2 & 0,2 & 0,2 & 0,4 & 2,05 & 5,17 \\
\hline Massa & 0,5 & 0,1 & 0,2 & 0,3 & 0,8 & 1,1 & 1,8 & 3,49 & 16,10 \\
\hline Refeição & 0,7 & 0,4 & 0,3 & 0,6 & 0,9 & 1,3 & 1,5 & 2,16 & 3,94 \\
\hline Salgadinho & 0,3 & 0,1 & 0,1 & 0,2 & 0,4 & 0,5 & 0,7 & 2,76 & 10,47 \\
\hline Sanduíche & 0,1 & 0,0 & 0,0 & 0,1 & 0,1 & 0,4 & 0,3 & 2,33 & 6,35 \\
\hline Outros & 0,5 & 0,2 & 0,3 & 0,4 & 0,6 & 0,8 & 1,0 & 2,24 & 5,61 \\
\hline Misturas industriais & 0,3 & 0,1 & 0,2 & 0,3 & 0,5 & 0,4 & 0,4 & 1,24 & 2,51 \\
\hline Mistura para bolo & 0,3 & 0,1 & 0,2 & 0,2 & 0,5 & 0,3 & 0,3 & 1,24 & 2,72 \\
\hline Outras & 0,0 & 0,0 & 0,0 & 0,0 & 0,0 & 0,1 & 0,0 & 1,22 & 1,43 \\
\hline Outros produtos & 0,0 & 0,0 & 0,1 & 0,0 & 0,1 & 0,0 & 0,1 & 1,30 & 1,79 \\
\hline SUBTOTAL & 264,5 & 203,0 & 239,9 & 266,0 & 291,3 & 313,1 & 351,6 & 1,33 & 1,73 \\
\hline Bebidas e infusões & 50,7 & 21,6 & 34,1 & 46,5 & 67,1 & 76,9 & 107,7 & 2,12 & 4,98 \\
\hline Bebidas alcoólicas & 6,8 & 2,1 & 3,9 & 5,3 & 9,2 & 11,3 & 19,2 & 2,83 & 8,99 \\
\hline Aguardente de cana & 0,2 & 0,2 & 0,3 & 0,2 & 0,2 & 0,1 & 0,1 & 0,61 & 0,51 \\
\hline Outras aguardentes & 0,0 & 0,0 & 0,0 & 0,0 & 0,0 & - & - & 0,00 & 0,00 \\
\hline Cerveja & 5,6 & 1,6 & 3,0 & 4,6 & 7,8 & 9,4 & 15,4 & 2,74 & 9,52 \\
\hline Vinho & 0,7 & 0,2 & 0,4 & 0,4 & 0,9 & 1,3 & 3,0 & 4,07 & 17,02 \\
\hline Outras & 0,2 & 0,1 & 0,2 & 0,1 & 0,3 & 0,5 & 0,7 & 2,77 & 6,53 \\
\hline Bebidas não alcoólicas & 40,8 & 16,9 & 27,4 & 37,9 & 54,8 & 62,2 & 84,8 & 2,08 & 5,01 \\
\hline Água mineral & 14,0 & 5,4 & 10,2 & 12,2 & 18,3 & 22,0 & 31,0 & 2,22 & 5,76 \\
\hline Refrigerante de cola & 12,7 & 4,7 & 6,8 & 12,0 & 18,5 & 19,8 & 26,7 & 2,11 & 5,70 \\
\hline Refrigerante de guaraná & 5,7 & 3,1 & 4,8 & 6,1 & 7,2 & 7,8 & 7,5 & 1,30 & 2,39 \\
\hline Refrigerante de laranja & 1,5 & 0,9 & 1,3 & 1,5 & 2,1 & 1,9 & 2,5 & 1,59 & 2,84 \\
\hline Refrigerante de limão & 0,8 & 0,2 & 0,6 & 0,8 & 1,0 & 1,1 & 1,8 & 2,24 & 9,65 \\
\hline Refrigerante de maçã & 0,1 & 0,0 & 0,1 & 0,1 & 0,1 & 0,2 & 0,4 & 4,14 & 15,14 \\
\hline Refrigerante de uva & 0,5 & 0,2 & 0,3 & 0,5 & 0,7 & 0,9 & 0,5 & 1,18 & 2,42 \\
\hline Bebida energética & 0,1 & 0,0 & 0,0 & 0,0 & 0,1 & 0,1 & 0,2 & 3,41 & 29,71 \\
\hline Refrigerante não especificado & 2,7 & 1,5 & 2,0 & 2,6 & 3,5 & 4,2 & 4,8 & 1,74 & 3,15 \\
\hline Outros refrigerantes & 0,6 & 0,3 & 0,4 & 0,5 & 0,8 & 0,6 & 1,2 & 2,09 & 4,36 \\
\hline Suco de fruta em pó & 0,4 & 0,3 & 0,3 & 0,4 & 0,5 & 0,4 & 0,4 & 1,07 & 1,57 \\
\hline Suco de fruta envasado & 1,5 & 0,3 & 0,5 & 0,8 & 1,7 & 2,6 & 6,6 & 4,45 & 20,98 \\
\hline Outras & 0,4 & 0,1 & 0,2 & 0,4 & 0,3 & 0,4 & 1,3 & 3,66 & 22,81 \\
\hline Cafés & 2,6 & 2,3 & 2,4 & 2,7 & 2,6 & 2,8 & 3,0 & 1,17 & 1,29 \\
\hline Café moído & 2,4 & 2,2 & 2,3 & 2,5 & 2,4 & 2,6 & 2,8 & 1,16 & 1,26 \\
\hline Café solúvel & 0,1 & 0,1 & 0,2 & 0,1 & 0,2 & 0,1 & 0,2 & 1,52 & 2,06 \\
\hline Outros & 0,04 & 0,03 & 0,03 & 0,06 & 0,03 & 0,04 & 0,02 & 0,59 & 0,68 \\
\hline Chás & 0,5 & 0,3 & 0,4 & 0,6 & 0,6 & 0,7 & 0,7 & 1,48 & 2,90 \\
\hline Chá-mate & 0,5 & 0,3 & 0,4 & 0,6 & 0,6 & 0,6 & 0,7 & 1,37 & 2,60 \\
\hline Outros & 0,02 & 0,00 & 0,00 & 0,01 & 0,01 & 0,03 & 0,08 & 4,82 & 41,00 \\
\hline SUBTOTAL & 315,2 & 224,7 & 274,0 & 312,5 & 358,4 & 390,0 & 459,3 & 1,46 & 2,04 \\
\hline
\end{tabular}

Fonte: IBGE, Diretoria de Pesquisas, Coordenação de Trabalho e Rendimento, Pesquisa de Orçamentos Familiares 2008-2009.

Nota: As quantidades de produtos adquiridos na forma líquida foram transformadas em $\mathrm{kg}$, considerando-se volume igual a peso.

(1) Inclusive sem rendimento. 